Welcome to the electronic edition of The Sound of William Barnes's Dialect Poems: 3. Poems of Rural Life in the Dorset Dialect, third collection (1862).

The book opens with the bookmark panel and you will see the contents page. Click on this anytime to return to the contents. You can also add your own bookmarks.

Each chapter heading in the contents table is clickable and will take you direct to the chapter. Return using the contents link in the bookmarks.

The whole document is fully searchable.

Enjoy.

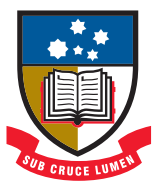

THE UNIVERSITY

of ADELAIDE 


\title{
The Sound of
}

\section{William Barnes's Dialect Poems}

\author{
3. Poems of Rural Life in the Dorset Dialect, \\ third collection (1862)
}

\section{by T. L. Burton}




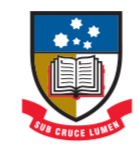

THE UNIVERSITY

of ADELAIDE

UNIVERSITY OF

ADELAIDE PRESS

\section{The Sound of William Barnes's Dialect Poems}

3. Poems of Rural Life in the Dorset Dialect, third collection (1862)

by T. L. Burton

From reviews of Volume 1 of The Sound of William Barnes's Dialect Poems:

This volume is the first of a series designed to supplement Burton's William Barnes's Dialect Poems: A Pronunciation Guide (2010) ... Together, these volumes constitute a monumental project which "sets out to provide a phonemic transcript and an audio recording of each individual poem in Barnes's three collections of Poems of Rural Life in the Dorset Dialect" ...

The driving force behind this project is Burton's enthusiasm for Barnes's work and his desire to bring these poems to life for the widest possible audience ... Recordings of Burton's lively, animated and accurate readings of each poem are provided on a free website hosted by Adelaide University Press, as is a free, searchable pdf version of the text ...

The Sound of William Barnes's Dialect Poems can ... be used by those without access to the Pronunciation Guide; so the pdf version effectively constitutes a free, comprehensive guide to Barnes's pronunciation, something for which both the author and the publisher are to be applauded.

-Joan C. Beal in Anglia.
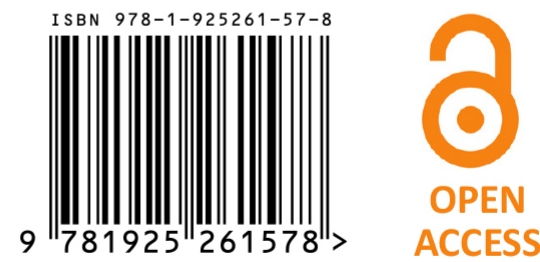

This book is available as a free ebook from adelaide.edu.au/press

Cover design by Emma Spoehr Cover image by Frederick William Newton Whitehead (1853-1938) 


\section{The Sound of}

William Barnes's Dialect Poems

3. Poems of Rural Life in the Dorset Dialect,

third collection 


\section{About this volume}

This is the third volume in a series that sets out to provide a phonemic transcript and an audio recording of each individual poem in Barnes's three collections of Poems of Rural Life in the Dorset Dialect. Its 96 poems include some of those most loved and admired: poems of heart-wrenching grief at the untimely deaths of Barnes's wife, Julia ("Woak Hill"), and their young son, Julius "The turnstile"); celebrations of love anticipated ("In the spring") and love fulfilled ("Don't ceäre"); protests against injustice and snobbery ("The love child"); struggles to accept God's will ("Grammer a-crippled"); comic poems ("John Bloom in Lon'on", "A lot o' maïdens a-runnèn the vields"); and poems on numerous other subjects, with an emotional range stretching from the deepest of grief to the highest of joy. The metrical forms show astonishing versatility, from straightforward octosyllabic couplets to challenging rhyme-schemes and innovative stanzaic patterns, widely varied line-lengths, and skilful adaptations of rhetorical devices from other languages.

T. L. Burton is an Emeritus Professor of English at the University of Adelaide.

Free audio files of T. L. Burton performing the poems in this book are available from

www.adelaide.edu.au/press/titles/barnes-vol-3/recordings

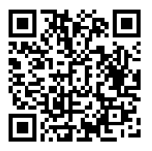

This book is available as a free fully-searchable PDF from www.adelaide.edu.au/press

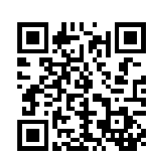




\section{The Sound of}

\section{William Barnes's Dialect Poems}

3. Poems of Rural Life in the Dorset Dialect,

third collection (1862)

as revised for the final collection (1879)

by

T. L. Burton

Department of English and Creative Writing

School of Humanities

The University of Adelaide

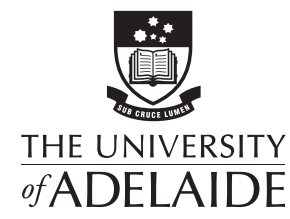

UNIVERSITY OF

ADELAIDE PRESS 
Published in Adelaide by

University of Adelaide Press

Barr Smith Library

The University of Adelaide

South Australia 5005

press@adelaide.edu.au

www.adelaide.edu.au/press

The University of Adelaide Press publishes externally refereed scholarly books by staff of the University of Adelaide. It aims to maximise access to the University's best research by publishing works through the internet as free downloads and for sale as high quality printed volumes.

\section{(C) 2017 T. L. Burton}

This work is licenced under the Creative Commons Attribution 4.0 International (CC BY-NC-ND 4.0) License. To view a copy of this licence, visit http://creativecommons.org/licenses/by/4.0/ or send a letter to Creative Commons, 444 Castro Street, Suite 900, Mountain View, California, 94041, USA. This licence allows for copying any part of the work for personal and commercial use, providing author attribution is clearly stated. Address all inquiries to the Director at the above address.

\section{(ब) $\Theta \Theta$}

For the full Cataloguing-in-Publication data please contact the National Library of Australia: cip@nla.gov.au

ISBN (paperback) 978-1-925261-57-8

ISBN (ebook) 978-1-925261-58-5

DOI: http://dx.doi.org/10.20851/barnes-vol-3

Cover illustration: The River Frome, Morton nr Dorchester, 1901 (oil on canvas), Whitehead, Frederick William Newton (1853-1938) / Private Collection / Photo (C) Peter Nahum at The Leicester Galleries, London / The Bridgeman Art Library Cover design: Emma Spoehr Paperback printed by SOS Print + Media Group, NSW, Australia 


\section{CONTENTS}

Preface

ix

Abbreviations $\quad x i$

Key to phonetic symbols $\quad$ xv

Alternative pronunciations $\quad$ xvi

Table of common alternatives xvii

Introduction

The spelling and pronunciation of the modified form of the dialect 1

Chief differences in spelling between the broad form of the dialect in 1844 and the modified form in 1879

A note on the text 21

"Zummer stream": a line-by-line phonemic analysis 21

Third-Collection Poems with phonemic transcripts

Woone smile mwore $\quad 32$

The echo 36

$\begin{array}{ll}\text { Vull a man } & 40\end{array}$

Nä̈ghbour plaÿmeätes $\quad 44$

$\begin{array}{ll}\text { The lark } & 48\end{array}$

The two churches $\quad 50$

Woak Hill 54

The hedger $\quad 58$

In the Spring $\quad 62$

The flood in Spring 66

$\begin{array}{ll}\text { Comèn hwome } & 70\end{array}$

$\begin{array}{ll}\text { Grammer a-crippled } & 72\end{array}$

$\begin{array}{ll}\text { The castle ruins } & 76\end{array}$

Eclogue: John, Jealous at Shroton Feäir $\quad 80$

Early plaÿmeäte 90

Pickèn o’ scroff $\quad 94$

Good night $\quad 98$

$\begin{array}{lr}\text { Went hwome } & 100\end{array}$

$\begin{array}{ll}\text { The hollow woak } & 102\end{array}$ 
Childern's childern

The rwose in the dark

Come

Zummer winds

The neäme letters

The new house a-gettèn wold

Zunday

The pillar'd geäte

Zummer stream

Linda Deäne

Eclogue: Come and zee us in the zummer

Lindenore

Me'th below the tree

Treat well your wife

The child an' the mowers

The love child

Hawthorn Down

Oben vields

What John wer a-tellèn his mis'ess out in the corn ground

Sheädes

Times o' year

Eclogue: Racketèn Joe

Zummer an' winter

To me

Two an' two

The lew o' the rick

The wind in woone's feäce

Tokens

Tweil

Fancy

The broken heart

Evenèn light

Vields by watervalls

The wheel routs

Nanny's new abode 
$\begin{array}{ll}\text { Leaves a-vallèn } & 216\end{array}$

$\begin{array}{ll}\text { Lizzie } & 220\end{array}$

$\begin{array}{ll}\text { Blessèns a-left } & 222\end{array}$

Fall time $\quad 226$

$\begin{array}{ll}\text { Fall } & 228\end{array}$

$\begin{array}{ll}\text { The zilver-weed } & 230\end{array}$

$\begin{array}{ll}\text { The widow's house } & 232\end{array}$

$\begin{array}{ll}\text { The child's greäve } & 236\end{array}$

$\begin{array}{ll}\text { Went vrom hwome } & 240\end{array}$

The fancy feäir at Maïden Newton $\quad 242$

$\begin{array}{ll}\text { Things do come round } & 246\end{array}$

Zummer thoughts in winter time 250

I'm out o' door $\quad 252$

Grief an' gladness 256

Slidèn 258

$\begin{array}{ll}\text { Lwonesomeness } & 262\end{array}$

$\begin{array}{ll}\text { A snowy night } & 266\end{array}$

$\begin{array}{ll}\text { The year-clock } & 268\end{array}$

$\begin{array}{ll}\text { Not goo hwome to-night } & 274\end{array}$

$\begin{array}{ll}\text { The humstrum } & 278\end{array}$

$\begin{array}{ll}\text { Shaftesbury Feäir } & 282\end{array}$

$\begin{array}{ll}\text { The beäten path } & 286\end{array}$

$\begin{array}{ll}\text { Ruth a-ridèn } & 290\end{array}$

Beauty undecked $\quad 294$

My love is good 296

Heedless o' my love $\quad 300$

The Do'set militia 304

A Do'set sale $\quad 308$

Don't ceäre $\quad 310$

$\begin{array}{ll}\text { Changes [1] } & 314\end{array}$

Kindness $\quad 318$

Withstanders $\quad 322$

Daniel Dwithen, the wise chap 326

Turnèn things off 330

The giants in treädes 334 
The little worold 338

$\begin{array}{ll}\text { Bad news } & 342\end{array}$

$\begin{array}{ll}\text { The turnstile } & 344\end{array}$

The better vor zeèn o' you 348

Pity 352

John Bloom in Lon'on 356

A lot o' maïdens a-runnèn the vields 364

$\begin{array}{ll}\text { Textual Notes } & 371\end{array}$

Appendix: A summary of sections 7 and 8 of WBPG 379 


\section{PREFACE}

This is the third volume in a series that sets out to provide a phonemic transcript and an audio recording of each poem in Barnes's three collections of Poems of Rural Life in the Dorset Dialect.

The individual volumes in the series are not designed to be critical editions: they do not contain variant readings from different versions of the poems or detailed notes on matters of linguistic, literary, social, historical, or biographical interest. The aim is simply to provide a self-contained, uncluttered, and reader-friendly text, which may be read on-screen or on the page, with marginal glosses for any words or phrases that might cause difficulty, together with audio recordings that may be freely audited online.

In addition to the many kind friends whose help is acknowledged in the Pronunciation Guide from which this series derives I wish particularly to thank John Emerson, Director of the University of Adelaide Press, and his staff, for their unshakeable patience and their staunch support. 



\section{ABBREVIATIONS}

1844

1847

1863 Grammar

1879

1886 Glossary

$a d v$.

AED

C

CS

cwl

DCC

Diss.

DWS
The first edition of Barnes's first collection of dialect poems, Poems of Rural Life, in the Dorset Dialect: With a Dissertation and Glossary (1844)

The second edition of Barnes's first collection of dialect poems (1847)

Barnes's A Grammar and Glossary of the Dorset Dialect with the History, Outspreading, and Bearings of South-Western English. Berlin: A. Asher for The Philological Society, 1863. Barnes's Poems of Rural Life in the Dorset Dialect. London: C. Kegan Paul, 1879 (containing the first, second, and third collections of Poems of Rural Life brought together in one volume.)

Barnes's A Glossary of the Dorset Dialect with a Grammar of Its Word Shapening and Wording. Dorchester: M. \& E. Case, County Printers; London: Trübner, 1886. adverb

Upton, Clive, and J. D. A. Widdowson. An Atlas of English Dialects. 2nd ed. London: Routledge, 2006.

Consonant

Comparative Specimen (in Part 5 of Ellis's On Early English Pronunciation)

Classified Word List (in Part 5 of Ellis's On Early English Pronunciation)

\section{Dorset County Chronicle}

The "Dissertation on the Dorset Dialect of the English Language" prefaced to 1844

Elworthy, Frederic Thomas. "The Dialect of West Somerset." Transactions of the Philological Society (1875-76): 197-272. English Dialect Society, Series D, Miscellaneous, 7. London: Trübner, 1875. 
EDD

EEP

Ellis

$\mathrm{eMnE}$

GenAm

Jennings

Jones

$L A E$

later editions

MacMahon

$\mathrm{ME}$

$\mathrm{OE}$

$O E D$

ppl.
The English Dialect Dictionary: Being the Complete Vocabulary of All Dialect Words Still in Use, or Known to Have Been in Use during the Last Two Hundred Years; Founded on the Publications of the English Dialect Society and on a Large Amount of Material Never Before Printed. Ed. Joseph Wright. 6 vols. London: H. Frowde; New York: G. P. Putnam's, 1898-1905.

On Early English Pronunciation (see Ellis)

Ellis, Alexander J. On Early English Pronunciation, with Especial Reference to Shakespere and Chaucer ... 5 parts. Early English Text Society, Extra Series 2, 7, 14, 23, 56. London: Trübner, 1867, 1869, 1871, 1874, 1889. early Modern English (roughly 16th \& 17th centuries) General American (pronunciation) Jennings, James. Observations on Some of the Dialects in the West of England, Particularly Somersetshire: With a Glossary of Words Now in Use There; and Poems and Other Pieces Exemplifying the Dialect. London: Printed for Baldwin, Cradock, and Joy, 1825.

Jones, Daniel. An Outline of English Phonetics. Leipzig: Teubner, 1918.

The Linguistic Atlas of England. Ed. Harold Orton, Stewart Sanderson, and John Widdowson. Atlantic Highlands, NJ: Humanities Press, 1977.

all editions of Barnes's dialect poems in the modified form of the dialect (i.e. from the mid 1850s onwards) MacMahon, Michael K. C. "Phonology." Chapter 5 of The Cambridge History of the English Language, Vol. 4, $1776-$ 1997. Ed. Suzanne Romaine. Cambridge: Cambridge Univ. Press, 1998.

Middle English (roughly 1100 to 1500)

Old English (up to about 1100)

The Oxford English Dictionary Online

$<$ http://www.oed.com>

past participle 
proto-RP

$\mathrm{RP}$

$S D D$

SED

StE

SW

$\mathrm{V}$

$v$.

Wakelin

WBCP

WBPG

Wells

Widén
The nineteenth-century forerunner of RP

Received pronunciation

Studies on the Dorset Dialect (see Widén)

Orton, Harold, and Eugen Dieth. Survey of English Dialects. Leeds: E. J. Arnold for the University of Leeds. (A) Introduction by Harold Orton, 1962. (B) The Basic Material. Vol. 4, The Southern Counties, ed. Harold Orton and Martyn F. Wakelin, 1967-68.

Standard English

Southwest(ern)

Vowel

verb

Wakelin, Martyn F. The Southwest of England. Varieties of English around the World. Text Series 5. Gen. Ed. Manfred Görlach. Amsterdam: Benjamins, 1986.

The Complete Poems of William Barnes. Ed. T. L. Burton and K. K. Ruthven. 3 vols. Oxford: Clarendon Press. 2013-. William Barnes's Dialect Poems: A Pronunciation Guide. By T. L. Burton. Adelaide and Provo, UT: The Chaucer Studio Press, 2010.

Wells, J. C. Accents of English. 3 vols. Cambridge: Cambridge Univ. Press, 1982.

Widén, Bertil. Studies on the Dorset Dialect. Lund Studies in English 16. Lund: Gleerup, 1949. Nendeln: Kraus, 1968. 



\section{KEY TO PHONETIC SYMBOLS}

Except where otherwise stated, words used in this key to illustrate the sounds are assumed to have the same pronunciation as in RP. Parentheses around a phonetic character indicate that it may be either sounded or silent; those around a length mark indicate that the preceding character may be either long or short. The symbols are a selection from amongst those offered by the International Phonetic Association, along lines similar to the usage in the Oxford English Dictionary, with some modifications.

\begin{tabular}{|c|c|c|}
\hline CONSONANTS & & \\
\hline $\mathrm{b}$ as in bin & $\mathrm{p}$ & as in pat \\
\hline as in $\operatorname{din}$ & $\mathrm{r}$ & as in rat \\
\hline $\mathrm{d}_{3}$ as in judge, gin & S & as in $\sin$ \\
\hline $\mathrm{f} \quad$ as in $f i n$ & $\int$ & as in shin \\
\hline as in get & $\mathrm{t}$ & as in tin \\
\hline as in hot & ts & as in $c h i n$ \\
\hline as in yet & $\theta$ & as in thin (voiceless th-) \\
\hline as in cat & ð & as in this (voiced th-) \\
\hline as in let & $\mathrm{v}$ & as in vat \\
\hline as in mat & $\mathrm{w}$ & as in win \\
\hline as in net & $\mathrm{z}$ & as in 200 \\
\hline as in sing & 3 & as in measure \\
\hline $\mathrm{yg}$ as in finger & & \\
\hline
\end{tabular}

\section{SHORT VOWELS}
a as in French madame
I as in pit
a as in GenAm hot
ə as in $\underline{a b o u t}$
$\mathrm{p}$ as in $p o t$
$\Lambda$ as in putt, cut
$\varepsilon$ as in pet
$\mathrm{U}$ as in put, foot
$\mathrm{i}$ as in French si
$\mathrm{u}$ as in French douce 
LONG VOWELS

$\begin{array}{ll}\text { a: as in German Tag or Australian } & \text { o: as in burn } \\ \text { carpark } & \text { o: as in born, dawn } \\ \text { E: as in German fährt } & \text { O: as in German Sohn } \\ \text { e: as in German Schnee } & \text { u: as in boon } \\ \text { i: as in bean } & \end{array}$

\section{DIPHTHONGS AND GLIDES}

æI as in Australian g'day, mate

jeə as in yair

iə as in fear

uə combines /u/ with /ə/

Eə as in fair

ว:I between buy and boy, with a

ja: as in German $j a$,,$\underline{a} b r$ long first element

je as in yet

je: as in German jäbrlich

o:u as in know, with a long first element

\section{ALTERNATIVE PRONUNCIATIONS}

As in StE, many common words may be pronounced in more than one way in Barnes's dialect. Wherever convenient, as with the final / $\mathrm{d} /$ of and, ground, etc., or the initial /h/ of when, where, etc., parentheses are used to show that a character may be either silent or sounded. Where this is not possible, as in the case of alternative vowel pronunciations, different readers may opt for different pronunciations, as may the same reader on different occasions. The commonest examples are collected in the table on the following page. The defining factor is often (but not necessarily) a matter of stress: column 2 shows the pronunciation that is most probable when the word is stressed; column 3 shows the pronunciation when it is unstressed or lightly stressed. In many instances readers may wish to substitute the alternative form for the form used in the transcripts of the poems in the main part of the book. 


\section{TABLE OF COMMON ALTERNATIVES}

The -es ending on plural nouns (when syllabic) may be either / Iz/ or / $\mathrm{oz} /$. The -est ending on superlative adjectives may be either /Ist/ or / əst/. The ending -ess in -ness, -less, etc. may be either /IS/ or /os/.

\begin{tabular}{|c|c|c|}
\hline Word & Stressed & Unstressed \\
\hline as & $\mathrm{az}$ & $\partial \mathrm{Z}$ \\
\hline at & at & ot \\
\hline but & $\mathrm{b} \Lambda \mathrm{t}$ & bət \\
\hline do & du: & də \\
\hline dost & $\mathrm{d}_{\Lambda} \mathrm{st}$ & dəst \\
\hline for $(v a r, v o r)$ & va:r & var, vər \\
\hline from & vrom & vrəm \\
\hline ha' ('have') & ha & hə \\
\hline he, 'e & (h)i: & ə \\
\hline must & $\mathrm{m} \Lambda \mathrm{s}(\mathrm{t})$ & $\operatorname{mos}(t)$ \\
\hline nor $($ nar, nor $)$ & nar & nar, nər \\
\hline or $(a r, o r)$ & a:r & ar, or \\
\hline so ('to that extent') & so: & So \\
\hline some & $\mathrm{s} \Lambda \mathrm{m}$ & səm \\
\hline than & ðan & ðən \\
\hline that & ðat & ðət \\
\hline the & $\begin{array}{l}\text { ði (before a } \\
\text { vowel) }\end{array}$ & $\begin{array}{l}\text { ðə (before a } \\
\text { consonant) }\end{array}$ \\
\hline their & ðعər, ðer & ðər \\
\hline there & ðعər, ðer & ðər \\
\hline to & $\operatorname{tu}(:)$ & to \\
\hline wher & (h)weər & (h)wər \\
\hline year & jərr, jiər & jiər \\
\hline you $(y o u, y a)$ & ju: & jə \\
\hline your & $\mathrm{ju}(\mathrm{s}) \partial \mathrm{r}$ & jər \\
\hline
\end{tabular}





\section{INTRODUCTION}

\section{The spelling and pronunciation of the modified form of the dialect}

Only three years elapsed between the publication of Barnes's second collection of Poems of Rural Life in the Dorset Dialect in 1859 and his third in 1862, but in those three years he made further changes in spelling beyond those he had already made in the second collection, almost all of them designed to bring the spelling still closer to that of StE. In several instances the StE spelling was itself adopted, as in father, path, half, and last in place of faether, paeth, haef, and laste or laest in 1859; day for 1859 dae; ridge and bridge for rudge and brudge; over for auver or awver; and -ow for -or in disyllabic words with unstressed final syllable, such as fellow, hollow, pillow, and window. In some other instances there was a partial move towards StE spelling, as in drough for 1859 droo ('through'); in others again, as in woone and woonce for oone and oonce ('one' and 'once'), the change appears to be designed to bring out the similarity with the initial sound of the words in RP rather than with the spelling of StE.

There were a few further changes in spelling in the second edition of the third collection (1869), and yet more (including the restoration of some broad forms that had earlier been abandoned) in the three-in-one collection of 1879, which became the standard edition of Barnes's dialect poems thereafter and from which the text in this book is taken. These individual changes do not concern us here; but I give below, in tabular form, a summary (repeated from Volume 2 of this series) of the chief spellings used in the final version of the modified form of the dialect in 1879, showing how they differ from the spellings of the broad form.

\section{Chief differences in spelling between the broad form of the dialect in 1844 and the modified form in 1879}

The table below is arranged alphabetically according to the spellings found in column 2-the spellings used in the poems appearing in this book-with occasional alternative spellings in parentheses. These are the spellings of the modified form of the dialect preferred by Barnes in 1879, his last published book of poems, containing revised versions of all three of his collections of 
Poems of Rural Life in the Dorset Dialect brought together in one volume. ${ }^{1}$ The spellings are followed by the intended pronunciation and selected examples. Column 1 gives the equivalent spellings used in the broad form of the dialect in 1844; column 3 shows the equivalent spelling in StE, with the pronunciation in RP; and column 4 gives references to those parts of $W B P G$ (a summary of which may be found in the Appendix to this volume) where the suggested pronunciation in Barnes's day is explained. Where no additional examples are given (as for after and among), the word in bold is itself the example. Words that are spelled and pronounced as in RP are omitted.

No attempt is made to record in the table the various changes Barnes made in his spelling in the years from 1856 (when he first began publishing poems written in the modified form of the dialect) to 1879 (when he published his last book of poems in dialect). For a detailed account of some of the major changes involved see WBCP ii, Appendix 3.

\begin{tabular}{|c|c|c|c|}
\hline $\begin{array}{c}1844 \text { spelling, } \\
\text { pronunciation, \& } \\
\text { examples }\end{array}$ & $\begin{array}{l}1879 \text { spelling, } \\
\text { pronunciation, \& } \\
\text { examples }\end{array}$ & $\begin{array}{l}\text { StE spelling, RP } \\
\text { pronunciation } \& \\
\text { examples }\end{array}$ & $\begin{array}{c}W B P G \\
\text { ref }\end{array}$ \\
\hline $\begin{array}{c}\text { a } \\
\text { /a/ } \\
\text { agg, bag, drashel, } \\
\text { lag, langth, stratch }\end{array}$ & $\begin{array}{c}\text { a } \\
\text { /a/ } \\
\text { agg, bag, drashel, } \\
\text { lag, langth, stratch }\end{array}$ & $\begin{array}{c}\mathbf{e} \\
/ \varepsilon / \\
\text { egg, beg, threshold, } \\
\text { leg, length, stretch }\end{array}$ & 7.2.3 \\
\hline $\begin{array}{l}\text { abrode } \\
\text { /abro:d/ }\end{array}$ & $\begin{array}{l}\text { abrode, abroad } \\
\text { /abro:d/ }\end{array}$ & $\begin{array}{l}\text { abroad } \\
\text { /abro:d/ }\end{array}$ & 7.13 .7 \\
\hline $\begin{array}{l}\text { à'ter, āter } \\
\text { / s:tor/ }\end{array}$ & $\begin{array}{l}\text { after } \\
\text { / } \varepsilon: \text { tər/ }\end{array}$ & $\begin{array}{l}\text { after } \\
\text { /a:ftor/ }\end{array}$ & 7.7.4 \\
\hline $\begin{array}{c}\text { age } \\
\text { /ع:d3/ } \\
\text { cage, wages }\end{array}$ & $\begin{array}{c}\text { age } \\
\text { /ع:d3/ } \\
\text { cage, wages }\end{array}$ & $\begin{array}{c}\text { age } \\
\text { /erd3/ } \\
\text { cage, wages }\end{array}$ & 7.11 .13 \\
\hline $\begin{array}{l}\text { agen, agiën, again } \\
/ \text { og\&n/,/ogjen/ }\end{array}$ & $\begin{array}{l}\text { ageän } \\
\text { /ogjen/ }\end{array}$ & $\begin{array}{c}\text { again } \\
\text { /ogern/, /ogen/ }\end{array}$ & 7.11 .4 \\
\hline
\end{tabular}

\footnotetext{
${ }^{1}$ For a more detailed discussion of the differences in spelling and grammar between 1844 and 1879 see T. L. Burton, "What William Barnes Done: Dilution of the Dialect in Later Versions of the Poems Of Rural Life," Review of English Studies 58 (2007): 338-63.
} 


\begin{tabular}{|c|c|c|c|}
\hline $\begin{array}{l}\text { agoo } \\
\text { /ogu:/ }\end{array}$ & $\begin{array}{l}\text { agoo } \\
\text { /ogu:/ }\end{array}$ & $\begin{array}{l}\text { ago } \\
\text { /agəu/ }\end{array}$ & 7.14 .6 \\
\hline $\begin{array}{c}\text { âi } \\
\text { /æi/ } \\
\text { afrâid, hâil, mâid, } \\
\text { prâise, râin, strâiight, } \\
\text { tâil, trâin, wâit }\end{array}$ & $\begin{array}{c}\text { aï } \\
\text { /æI/ } \\
\text { afraï, hail, maïd, } \\
\text { praïse, raïn, straïght, } \\
\text { taill, traïn, waït }\end{array}$ & $\begin{array}{c}\text { ai } \\
\text { /eI/ } \\
\text { afraid, hail, maid, } \\
\text { praise, rain, straight, } \\
\text { tail, train, wait }\end{array}$ & 7.11 .6 \\
\hline $\begin{array}{c}\text { âi } \\
\text { /æi/ } \\
\text { nâighbour, âight, } \\
\text { wâight, vâil }\end{array}$ & $\begin{array}{c}\text { aï } \\
\text { /æi/ } \\
\text { naïghbour, aïght, } \\
\text { waïght, vail }\end{array}$ & $\begin{array}{c}\text { ei } \\
\text { /eI/ } \\
\text { neighbour, eight, } \\
\text { weight, veil }\end{array}$ & 7.11.6 \\
\hline $\begin{array}{l}\text { âir } \\
\text { /æir/ }\end{array}$ & $\begin{array}{l}\text { aïr } \\
\text { /æir/ }\end{array}$ & $\begin{array}{l}\text { air } \\
/ \varepsilon \partial /\end{array}$ & $\begin{array}{l}7.20 .5 \\
8.8 .1\end{array}$ \\
\hline $\begin{array}{c}\text { afe, āfe, āf } \\
\text { /ع:f/ } \\
\text { cafe, hafe, hāfe, lāf, } \\
\text { lāfe, lafe }\end{array}$ & $\begin{array}{c}\text { alf, augh } \\
\text { / ع:f/ } \\
\text { calf, half, laugh }\end{array}$ & $\begin{array}{c}\text { alf, augh } \\
\text { /a:f/ } \\
\text { calf, half, laugh }\end{array}$ & 7.7.4 \\
\hline $\begin{array}{c}\text { āk(e), } \bar{a}^{\prime} \mathbf{k}(\mathbf{e}) \\
\text { / ع:k/, /a:k/ } \\
\text { chāk, stā'k, tā'k(e), } \\
\text { ta'k(e), wā'k(e), } \\
\text { wa'k(e) }\end{array}$ & $\begin{array}{c}\text { alk } \\
/ \text { \&:k/ } \\
\text { chalk, stalk, talk, } \\
\text { walk }\end{array}$ & $\begin{array}{c}\text { alk } \\
\text { / ok } / \\
\text { chalk, stalk, talk, } \\
\text { walk }\end{array}$ & 7.13 .2 \\
\hline $\begin{array}{c}\text { al, al', âl, āl, all, āll } \\
\text { /a:l/, / ع:l/ } \\
\text { al, al', āl, cal, call, } \\
\text { cāll, val, vall, vāl, } \\
\text { hal, hall, smal, small, } \\
\text { smāl, squal, sqâl, } \\
\text { squāl }\end{array}$ & $\begin{array}{c}\text { all } \\
\text { /a:l/ } \\
\text { all, call, fall, hall, } \\
\text { small, squall }\end{array}$ & $\begin{array}{c}\text { all } \\
\text { /o:l/ } \\
\text { all, call, fall, hall, } \\
\text { small, squall }\end{array}$ & 7.13.1 \\
\hline $\begin{array}{c}\text { always, ālwiz } \\
\text { /a:lwe:z/, / \&:lwı/ }\end{array}$ & $\begin{array}{l}\text { always } \\
\text { /a:lwe:z/ }\end{array}$ & $\begin{array}{l}\text { always } \\
\text { /o:lweız/ }\end{array}$ & 7.11 .8 \\
\hline $\begin{array}{l}\text { among } \\
\text { /əmpy/ }\end{array}$ & $\begin{array}{l}\text { among } \\
\text { /ompy/ }\end{array}$ & $\begin{array}{l}\text { among } \\
/ \mathrm{\partial m} \wedge \mathrm{y} /\end{array}$ & 7.8.3 \\
\hline
\end{tabular}




\begin{tabular}{|c|c|c|c|}
\hline $\begin{array}{c}\text { ānce, āns } \\
\text { / E:ns / } \\
\text { dānce, glānce, } \\
\text { ānswer }\end{array}$ & $\begin{array}{c}\text { ance, ans } \\
\text { / E:ns } / \\
\text { dance, glance, } \\
\text { answer }\end{array}$ & $\begin{array}{c}\text { ance, ans } \\
\text { /ains/ } \\
\text { dance, glance, } \\
\text { answer }\end{array}$ & 7.7 .4 \\
\hline $\begin{array}{c}\text { annge } \\
\text { /andz/ } \\
\text { anngel, channge, } \\
\text { dannger, strannge(r) }\end{array}$ & $\begin{array}{c}\text { ange } \\
\text { /and3/ } \\
\text { angel, change, } \\
\text { danger, strange }(r)\end{array}$ & $\begin{array}{c}\text { ange } \\
\text { /eindz/ } \\
\text { angel, change, } \\
\text { danger, strange(r) }\end{array}$ & 7.11 .12 \\
\hline $\begin{array}{c}\text { ar } \\
\text { /arr } / \\
\text { warm, swarm, } \\
\text { toward }\end{array}$ & $\begin{array}{c}\text { ar } \\
\text { /air } / \\
\text { warm, swarm, } \\
\text { toward }\end{array}$ & $\begin{array}{c}\text { ar } \\
\text { / s: } / \\
\text { warm, swarm, } \\
\text { toward }\end{array}$ & $\begin{array}{c}7.22 .2 \\
8.8 .1\end{array}$ \\
\hline $\begin{array}{c}\text { ar } \\
\text { /arr } / \\
\text { larn, sar, sarve, } \\
\text { sarch }\end{array}$ & $\begin{array}{c}\text { ar, ear } \\
\text { /arr/ } \\
\text { larn, learn, sar, } \\
\text { sarve, sarch }\end{array}$ & $\begin{array}{c}\text { er, ear } \\
/ \text { ə:/ } \\
\text { learn, serve, search }\end{array}$ & $\begin{array}{l}7.9 .2 \\
8.8 .1\end{array}$ \\
\hline $\begin{array}{c}\text { ar, ear } \\
\text { /arr/ } \\
\text { cart, dark, farm, } \\
\text { harm, heart }\end{array}$ & $\begin{array}{c}\text { ar, ear } \\
\text { /arr/ } \\
\text { cart, dark, farm, } \\
\text { harm, heart }\end{array}$ & $\begin{array}{c}\text { ar, ear } \\
\text { /a:/ } \\
\text { cart, dark, farm, } \\
\text { harm, heart }\end{array}$ & $\begin{array}{c}7.21 .1 \\
8.8 .1\end{array}$ \\
\hline $\begin{array}{c}\text { are, ear } \\
\text { / } \varepsilon r r / \\
\text { square, ware, bear, } \\
\text { wear }\end{array}$ & $\begin{array}{c}\text { are, ear } \\
\text { / } \text { cor } / \\
\text { square, ware, bear, } \\
\text { wear }\end{array}$ & 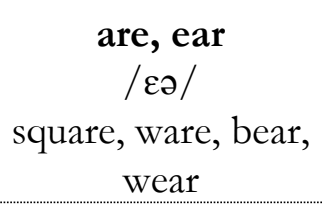 & $\begin{array}{c}7.20 .1 \\
8.8 .1\end{array}$ \\
\hline $\begin{array}{c}\text { ass } \\
\text { /ais } / \\
\text { brass, glass, grass, } \\
\text { pass }\end{array}$ & $\begin{array}{c}\text { ass } \\
\text { /a:s } / \\
\text { brass, glass, grass, } \\
\text { pass }\end{array}$ & $\begin{array}{c}\text { ass } \\
\text { /ars } / \\
\text { brass, glass, grass, } \\
\text { pass }\end{array}$ & 7.7 .1 \\
\hline $\begin{array}{c}\text { ass } \\
/ \mathrm{a}(\mathrm{:}) \mathrm{s} / \\
\text { ass, lass, cassen }\end{array}$ & $\begin{array}{c}\text { ass } \\
/ \mathrm{a}(\mathrm{i}) \mathrm{s} / \\
\text { ass, lass, cassen }\end{array}$ & $\begin{array}{c}\text { ass } \\
\text { /æs } / \\
\text { ass, lass, canst not }\end{array}$ & 7.7.2 \\
\hline $\begin{array}{c}\text { āth, aeth } \\
/ \varepsilon: ð /, / \varepsilon: \theta / \\
\text { fāther, faether, pāth }\end{array}$ & $\begin{array}{c}\text { ath } \\
/ \varepsilon: ð /, / \varepsilon: \theta / \\
\text { father, path }\end{array}$ & $\begin{array}{l}\text { ath } \\
\text { /a:ð/, /a: } \theta / \\
\text { father, path }\end{array}$ & 7.7 .4 \\
\hline
\end{tabular}




\begin{tabular}{|c|c|c|c|}
\hline $\begin{array}{l}\text { athirt } \\
\text { /əðə:rt/ }\end{array}$ & $\begin{array}{l}\text { ath irt } \\
\text { /əðə:rt/ }\end{array}$ & 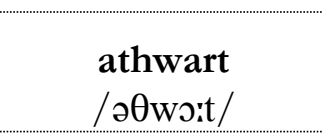 & $\begin{array}{l}8.16 .2 \\
8.8 .1\end{array}$ \\
\hline $\begin{array}{c}\text { al, a'l, āl } \\
\text { /a:l/, / ع:l/ } \\
\text { bal, crâl, hal, hāl, } \\
\text { ma'l, spra'l, sprāl }\end{array}$ & $\begin{array}{c}\text { aul, awl } \\
\text { /o:l/ } \\
\text { bawl, crawl, haul } \\
\text { (hawl), mawl, sprawl }\end{array}$ & $\begin{array}{c}\text { aul, awl } \\
\text { / o:l/ } \\
\text { bawl, crawl, haul, } \\
\text { maul, sprawl }\end{array}$ & 7.13 .1 \\
\hline $\begin{array}{c}\text { àn, āen } \\
\text { / } \mathbf{e}: n / \\
\text { flānt, hānt(e), } \\
\text { sānter, māen }\end{array}$ & $\begin{array}{c}\text { aun, awn, an } \\
\text { / E:n/ } \\
\text { flant, haunt, saunter, } \\
\text { mawn }\end{array}$ & $\begin{array}{c}\text { aun, awn } \\
\text { /o:n/ } \\
\text { flaunt, haunt, } \\
\text { saunter, mawn } \\
\text { ('basket') }\end{array}$ & 7.13 .3 \\
\hline $\begin{array}{c}\text { ānt, an't } \\
\text { /ع:nt / } \\
\text { ānt, cānt, can't, slānt }\end{array}$ & $\begin{array}{l}\text { aunt, ant, an't } \\
\quad \text { / ع:nt/ } \\
\text { aunt, can't, slant }\end{array}$ & $\begin{array}{l}\text { aunt, ant, an't } \\
\quad \text { /a:nt/ } \\
\text { aunt, can't, slant }\end{array}$ & 7.7.4 \\
\hline $\begin{array}{c}\text { avore } \\
\text { /ovuər/, /ovo:r/ }\end{array}$ & $\begin{array}{c}\text { avore } \\
\text { /ovuər/, /ovorr/ }\end{array}$ & $\begin{array}{l}\text { afore } \\
\text { /ofo:/ }\end{array}$ & $\begin{array}{l}7.23 .4 \\
8.8 .1\end{array}$ \\
\hline $\begin{array}{l}\text { awoy } \\
\text { /əwə:I/ }\end{array}$ & $\begin{array}{l}\text { away (awoy) } \\
\text { /owe:/, / owə:I/ }\end{array}$ & $\begin{array}{l}\text { away } \\
\text { /oweI/ }\end{array}$ & 7.11 .8 \\
\hline $\begin{array}{c}\text { ax } \\
\text { /a:ks/ }\end{array}$ & $\begin{array}{c}\text { ax } \\
/ \mathrm{a} k \mathrm{ks} /\end{array}$ & $\begin{array}{l}\text { ask } \\
\text { /a:sk/ }\end{array}$ & 8.9 .2 \\
\hline $\begin{array}{c}\text { ây } \\
\text { /æı/ } \\
\text { bây, gây, hây, mây, } \\
\text { pây, plây, prây(er), } \\
\text { sprây, stây, swây }\end{array}$ & 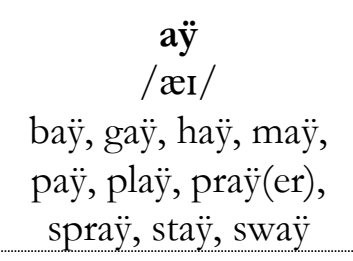 & $\begin{array}{c}\text { ay } \\
\text { /eI/ } \\
\text { bay, gay, hay, may, } \\
\text { pay, play, pray(er), } \\
\text { spray, stay, sway }\end{array}$ & 7.11.6 \\
\hline $\begin{array}{c}\text { à, a, āe, ae, æe, è } \\
\text { /e:/ } \\
\text { clāa , lāe, lae, zāa, zae, } \\
\text { grē (in grēgole } \\
\text { 'bluebell'), whē }\end{array}$ & $\begin{array}{c}\text { ay, ey } \\
\text { /e:/ } \\
\text { clay, lay, zay, grey } \\
\text { (gray), whey }\end{array}$ & $\begin{array}{c}\text { ay, ey } \\
\text { /ei/ } \\
\text { clay, lay, say, grey, } \\
\text { whey }\end{array}$ & 7.11.7 \\
\hline $\begin{array}{c}\text { beät } \\
\text { /biət/,/bjet/ }\end{array}$ & $\begin{array}{c}\text { beät } \\
\text { /biət/,/bjet/ }\end{array}$ & $\begin{array}{l}\text { beat } \\
\text { /bitt/ }\end{array}$ & 7.11 .3 \\
\hline $\begin{array}{l}\text { bekiaze, bekiase } \\
\text { /bikje:z/ }\end{array}$ & $\begin{array}{l}\text { because } \\
\text { /bikje:z/ }\end{array}$ & $\begin{array}{l}\text { because } \\
\text { /bıkbz/ }\end{array}$ & 7.13 .4 \\
\hline
\end{tabular}




\begin{tabular}{|c|c|c|c|}
\hline $\begin{array}{c}\text { bin, ben } \\
/ \text { bin/,/ben/ }\end{array}$ & $\begin{array}{l}\text { been (ben) } \\
\text { /bin/,/ben/ }\end{array}$ & $\begin{array}{l}\text { been } \\
\text { /bi:n/ }\end{array}$ & 7.10 .1 \\
\hline $\begin{array}{l}\text { bewar } \\
\text { /biwa:r/ }\end{array}$ & $\begin{array}{l}\text { bewar } \\
\text { /biwa:r/ }\end{array}$ & $\begin{array}{l}\text { beware } \\
\text { /biweə/ }\end{array}$ & $\begin{array}{l}7.20 .7 \\
8.8 .1\end{array}$ \\
\hline $\begin{array}{c}\text { beyand, beyond } \\
\text { /bijand/ }\end{array}$ & $\begin{array}{c}\text { beyond (beyand) } \\
\text { /bijand/ }\end{array}$ & $\begin{array}{l}\text { beyond } \\
\text { /bijpnd/ }\end{array}$ & 7.4 \\
\hline $\begin{array}{l}\text { blather } \\
\text { /bladər/ }\end{array}$ & $\begin{array}{l}\text { blath er } \\
\text { /blaðər/ }\end{array}$ & $\begin{array}{l}\text { bladder } \\
\text { /blædər/ }\end{array}$ & $\begin{array}{l}8.2 .3 \\
8.8 .1\end{array}$ \\
\hline $\begin{array}{l}\text { bote, bo'te } \\
\text { /bo:t/ }\end{array}$ & $\begin{array}{c}\text { bought } \\
\text { /bo:t/,/bo:t/ }\end{array}$ & $\begin{array}{l}\text { bought } \\
\text { /bort/ }\end{array}$ & $7.13 .8 \mathrm{~b}$ \\
\hline $\begin{array}{c}\text { brēak, brē'k, break } \\
\text { /bre:k/,/brjek/ }\end{array}$ & $\begin{array}{l}\text { break } \\
\text { /bre:k/ }\end{array}$ & $\begin{array}{l}\text { break } \\
\text { /bresk/ }\end{array}$ & 7.11.11 \\
\hline $\begin{array}{l}\text { brudge } \\
\text { /brıd3/ }\end{array}$ & $\begin{array}{c}\text { bridge (brudge) } \\
\text { /brAd } 3 /\end{array}$ & $\begin{array}{l}\text { bridge } \\
\text { /brid3/ }\end{array}$ & 7.1.4a \\
\hline $\begin{array}{l}\text { brode } \\
\text { /bro:d/ }\end{array}$ & $\begin{array}{l}\text { broad, brode } \\
\text { /bro:d/ }\end{array}$ & $\begin{array}{l}\text { broad } \\
\text { /bro:d/ }\end{array}$ & 7.13 .7 \\
\hline $\begin{array}{l}\text { brote, brōte, } \\
\text { brought } \\
\text { /bro:t/,/bro:t/ }\end{array}$ & $\begin{array}{l}\text { brought (brote) } \\
\text { /bro:t/, /bro:t/ }\end{array}$ & $\begin{array}{l}\text { brought } \\
\text { /bro:t/ }\end{array}$ & $7.13 .8 \mathrm{~b}$ \\
\hline $\begin{array}{l}\text { buoy } \\
\text { /bwə:I/ }\end{array}$ & $\begin{array}{l}\text { bwoy } \\
\text { /bwə:I/ }\end{array}$ & $\begin{array}{l}\text { boy } \\
\text { /boi/ }\end{array}$ & 7.17 .4 \\
\hline $\begin{array}{l}\text { cage } \\
/ \mathrm{k} \varepsilon: \mathrm{d} 3 /\end{array}$ & $\begin{array}{l}\text { cage } \\
/ \mathrm{k} \varepsilon: \mathrm{d} 3 /\end{array}$ & $\begin{array}{l}\text { cage } \\
\text { / keId3/ }\end{array}$ & 7.11 .13 \\
\hline $\begin{array}{c}\text { car } \\
/ \text { karr/ }\end{array}$ & $\begin{array}{c}\text { car } \\
/ \text { ka:r/ }\end{array}$ & $\begin{array}{l}\text { carry } \\
\text { /kæri/ }\end{array}$ & 7.3.4 \\
\hline $\begin{array}{l}\text { kiard } \\
\text { /kja:rd/ }\end{array}$ & $\begin{array}{c}\text { ceärd } \\
\text { /kja:rd/ }\end{array}$ & $\begin{array}{l}\text { card } \\
/ \mathrm{ka}: \mathrm{d} /\end{array}$ & $\begin{array}{c}7.21 .2 \\
8.8 .1\end{array}$ \\
\hline $\begin{array}{l}\text { chammer } \\
\text { /tfamor/ }\end{array}$ & $\begin{array}{l}\text { chammer } \\
\text { /tfamor/ }\end{array}$ & $\begin{array}{l}\text { chamber } \\
\text { /t termbo/ }\end{array}$ & 7.11 .12 \\
\hline $\begin{array}{l}\text { cheäk } \\
\text { /tfiək/ }\end{array}$ & $\begin{array}{l}\text { cheäk } \\
\text { /tfiək/ }\end{array}$ & $\begin{array}{l}\text { cheek } \\
/ \mathrm{t} \text { ji:k/ }\end{array}$ & 7.10 .13 \\
\hline
\end{tabular}




\begin{tabular}{|c|c|c|c|}
\hline $\begin{array}{l}\text { cheem } \\
\text { /t fi:m/ }\end{array}$ & $\begin{array}{l}\text { cheem } \\
\text { /t fi:m/ }\end{array}$ & $\begin{array}{l}\text { chime } \\
/ \mathrm{t} \text { Sam/ }\end{array}$ & 7.10 .2 \\
\hline 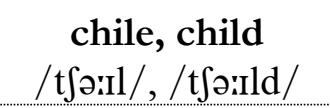 & 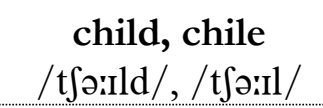 & $\begin{array}{l}\text { child } \\
\text { /tfarld/ }\end{array}$ & 7.16 .4 \\
\hline $\begin{array}{l}\text { clavy } \\
\text { /klavi/ }\end{array}$ & $\begin{array}{l}\text { clavy } \\
\text { /klavi/ }\end{array}$ & $\begin{array}{c}\text { clavel } \\
\text { /klævəl/ }\end{array}$ & 7.3.4 \\
\hline $\begin{array}{l}\text { clim, clim' } \\
\text { / klim/ }\end{array}$ & $\begin{array}{c}\text { clim' (climb) } \\
\text { / klim/ }\end{array}$ & $\begin{array}{l}\text { climb } \\
\text { /klaim/ }\end{array}$ & 7.16 .4 \\
\hline $\begin{array}{c}\operatorname{clum}(p p l .) \\
/ \mathrm{k} l_{\wedge \mathrm{m} /}\end{array}$ & $\begin{array}{c}\operatorname{clom}(p p l .) \\
/ \mathrm{kl} \Lambda \mathrm{m} /\end{array}$ & $\begin{array}{l}\text { climbed } \\
\text { /klaimd/ }\end{array}$ & 7.16 .10 \\
\hline $\begin{array}{c}\text { clomb (past tense) } \\
/ \mathrm{kl} \Lambda \mathrm{m} /\end{array}$ & $\begin{array}{c}\text { clomb (past tense) } \\
/ \mathrm{kl} \Lambda \mathrm{m} /\end{array}$ & $\begin{array}{l}\text { climbed } \\
\text { / klaimd/ }\end{array}$ & 7.16 .10 \\
\hline $\begin{array}{l}\text { cloas, cloaz } \\
\text { /klo:z/ }\end{array}$ & $\begin{array}{l}\text { clothes } \\
\text { /klo:z/ }\end{array}$ & $\begin{array}{l}\text { clothes } \\
\text { /klouðz/ }\end{array}$ & 8.13 .3 \\
\hline $\begin{array}{l}\text { coose } \\
\text { / kuis/ }\end{array}$ & $\begin{array}{l}\text { coo'se } \\
\text { / ku:s/ }\end{array}$ & $\begin{array}{l}\text { course } \\
/ \mathrm{kos} /\end{array}$ & $7.23 .6 \mathrm{~b}$ \\
\hline $\begin{array}{l}\text { curdle } \\
\text { /kərrdəl/ }\end{array}$ & $\begin{array}{c}\text { curl } \\
\text { /kə:rdəl/, / kə:rl/ }\end{array}$ & $\begin{array}{l}\text { curl } \\
/ \mathrm{k} ə \mathrm{ll} /\end{array}$ & $\begin{array}{l}8.8 .4 \\
8.8 .1\end{array}$ \\
\hline $\begin{array}{c}\text { daeter, dāter, } \\
\text { dā'ter } \\
\text { /de:tor/ }\end{array}$ & $\begin{array}{c}\text { daughter (dā’ter) } \\
\text { /de:tər/ }\end{array}$ & $\begin{array}{c}\text { daughter } \\
\text { /doito/ }\end{array}$ & $\begin{array}{l}7.13 .5 \\
8.8 .1\end{array}$ \\
\hline $\begin{array}{c}\text { dā, dae, dāe, da', } \\
\text { dây } \\
/ \text { de: } /, / d æ i /\end{array}$ & $\begin{array}{c}\text { day (daÿ) } \\
\text { /de:/ }\end{array}$ & $\begin{array}{l}\text { day } \\
\text { /deI/ }\end{array}$ & 7.11.7 \\
\hline $\begin{array}{c}\text { da (unstressed) } \\
/ \text { do/ }\end{array}$ & $\begin{array}{c}\text { do (unstressed) } \\
/ \text { do/ }\end{array}$ & $\begin{array}{l}\text { do } \\
\text { /du:/ }\end{array}$ & 7.15 .5 \\
\hline $\begin{array}{l}\text { dont, don't } \\
\text { /do:nt/ }\end{array}$ & $\begin{array}{c}\text { don't (dont) } \\
\text { /do:nt/ }\end{array}$ & $\begin{array}{l}\text { don't } \\
\text { /dount/ }\end{array}$ & 7.14 .14 \\
\hline $\begin{array}{c}\text { door } \\
\text { /duər/,?/də:uər/ }\end{array}$ & $\begin{array}{c}\text { door } \\
\text { /duər/,?/dəruər/ }\end{array}$ & $\begin{array}{l}\text { door } \\
\text { /do:/ }\end{array}$ & $\begin{array}{l}7.23 .2 \\
8.8 .1\end{array}$ \\
\hline
\end{tabular}




\begin{tabular}{|c|c|c|c|}
\hline $\begin{array}{c}\mathbf{d r} \text { (initial) } \\
/ \mathrm{dr} / \\
\text { drash, drashel, } \\
\text { dreat, dree, droat, } \\
\text { droo, drow }\end{array}$ & $\begin{array}{c}\text { dr (initial) } \\
/ \text { dr/ } \\
\text { drash, drashel, } \\
\text { dreat, dree, droat, } \\
\text { droo, drow }\end{array}$ & $\begin{array}{c}\text { thr (initial) } \\
/ \text { Or/ } \\
\text { thrash, threshold, } \\
\text { threat, three, throat, } \\
\text { through, throw }\end{array}$ & 8.14 \\
\hline $\begin{array}{l}\text { drēve } \\
\text { /dre:v/ }\end{array}$ & $\begin{array}{c}\text { dreve (drēve) } \\
\text { /dre:v/ }\end{array}$ & $\begin{array}{l}\text { drive } \\
\text { /draiv/ }\end{array}$ & 7.10 .6 \\
\hline $\begin{array}{c}\mathbf{e} \\
/ \varepsilon / \\
\text { peck, het, spet, ef }\end{array}$ & $\begin{array}{c}\mathbf{e} \\
/ \varepsilon / \\
\text { peck, het, spet }\end{array}$ & $\begin{array}{c}\mathbf{i} \\
/ \mathrm{I} / \\
\text { pick, hit, spit, if }\end{array}$ & $7.1 .4 \mathrm{~b}$ \\
\hline $\begin{array}{c}\text { èa, è } \\
\text { /e:/, /i:/ } \\
\text { dēal, drēm, ēat, } \\
\text { rēach, strēam }\end{array}$ & $\begin{array}{c}\text { ea } \\
/ \mathrm{i}: /, / \mathrm{e}: / \\
\text { deal, dream, eat, } \\
\text { reach, stream }\end{array}$ & $\begin{array}{c}\text { ea } \\
/ \mathrm{i}: / \\
\text { deal, dream, eat, } \\
\text { reach, stream }\end{array}$ & 7.10 .4 \\
\hline $\begin{array}{c}\text { ya }(\text { initial) } \\
/ \mathbf{j} \varepsilon / \\
\text { yable, yacre, yache, } \\
\text { yal(e), yapern }\end{array}$ & $\begin{array}{c}\text { eä (initial) } \\
/ \text { je/ } \\
\text { eäble, eäcre, eäche, } \\
\text { eäle, eäpern, eäpron }\end{array}$ & $\begin{array}{c}\text { a (initial) } \\
\text { /eI/ } \\
\text { able, acre, ache, ale, } \\
\text { apron }\end{array}$ & 7.11 .5 \\
\hline $\begin{array}{c}\text { eä (medial) } \\
\text { /iə/ } \\
\text { beän, feäst, leäd, } \\
\text { leäve, meäd }\end{array}$ & $\begin{array}{c}\text { eä (medial) } \\
\text { /iə/ } \\
\text { beän, feäst, leäd, } \\
\text { leäve, meäd }\end{array}$ & $\begin{array}{c}\text { ea (medial) } \\
\text { /i:/ } \\
\text { bean, feast, lead, } \\
\text { leave, mead }\end{array}$ & $\begin{array}{l}7.10 .8 \\
7.11 .2\end{array}$ \\
\hline $\begin{array}{l}\mathbf{i a}+\mathbf{C}+\mathbf{e}, \mathbf{i a}+\mathbf{C}+\mathbf{y} \\
\qquad / \mathbf{j} \varepsilon / \\
\text { biake, griace, griave, } \\
\text { liady, miake, niame, } \\
\text { shiade, shiape, siake, } \\
\text { siame, riace }\end{array}$ & $\begin{array}{c}\text { eä+C+e, eä+C+y } \\
\text { /je/ } \\
\text { beäke, greäce, } \\
\text { greäve, leädy, } \\
\text { meäke, neäme, } \\
\text { sheäde, sheäpe, } \\
\text { seäke, seäme, reäce }\end{array}$ & $\begin{array}{c}\text { a+C+e, a+C+y } \\
\text { /eI/ } \\
\text { bake, grace, grave, } \\
\text { lady, make name, } \\
\text { shade, shape, sake, } \\
\text { same, race }\end{array}$ & 7.11.1-2 \\
\hline $\begin{array}{c}\text { iair, iare } \\
\text { /jøər/ } \\
\text { fiair, hiair, piair, } \\
\text { diairy, viairy, } \\
\text { biare, bliare, miare, } \\
\text { shiare }\end{array}$ & $\begin{array}{c}\text { eäir, eäre } \\
\text { /jeər/ } \\
\text { feäir, heäir, peäir, } \\
\text { deäiry, veäiry, } \\
\text { beäre, bleäre, meäre, } \\
\text { sheäre }\end{array}$ & $\begin{array}{c}\text { air, are } \\
\text { / əə/ } \\
\text { fair, hair, pair, dairy, } \\
\text { fairy, } \\
\text { bare, blare, mare, } \\
\text { share }\end{array}$ & $\begin{array}{l}7.20 .2 \\
8.8 .1\end{array}$ \\
\hline
\end{tabular}




\begin{tabular}{|c|c|c|c|}
\hline $\begin{array}{c}\text { ear, yer (final or } \\
\text { medial) } \\
\text { /ior/,/jar/ }\end{array}$ & $\begin{array}{c}\text { ear (final or medial) } \\
\text { /iər/ }\end{array}$ & $\begin{array}{c}\text { ear (final or medial) } \\
\text { /Iə/ }\end{array}$ & $\begin{array}{l}7.19 .3 \\
8.5 .5 \\
8.8 .1\end{array}$ \\
\hline $\begin{array}{c}\text { yar (initial) } \\
\text { /jarr/ } \\
\text { yarn, yarnest, yarbs }\end{array}$ & $\begin{array}{c}\text { eär (initial) } \\
\text { /ja:r/ } \\
\text { eärn, eärnest, eärbs }\end{array}$ & $\begin{array}{l}\text { ear, (h)er (initial) } \\
\text { /orr/ } \\
\text { earn, earnest, herbs }\end{array}$ & 7.9.3 \\
\hline $\begin{array}{l}\text { yer, ear (word) } \\
\text { /jərr/, /iər/ }\end{array}$ & $\begin{array}{l}\text { ear (word) } \\
\text { /jərr/, /iər/ }\end{array}$ & $\begin{array}{l}\text { ear (word) } \\
/ \text { Iə/ }\end{array}$ & $\begin{array}{l}7.19 .3 \\
8.5 .5 \\
8.8 .1\end{array}$ \\
\hline $\begin{array}{l}\text { ear, eer, ere } \\
\text { /iər/ } \\
\text { clear, dear, hear, } \\
\text { near, beer, cheer, } \\
\text { here }\end{array}$ & $\begin{array}{c}\text { ear, eer, ere } \\
\text { /iər/ } \\
\text { clear, dear, hear, } \\
\text { near, beer, cheer, } \\
\text { here }\end{array}$ & $\begin{array}{c}\text { ear, eer, ere } \\
\text { /ıə/ } \\
\text { clear, dear, hear, } \\
\text { near, beer, cheer, } \\
\text { here }\end{array}$ & $\begin{array}{l}7.19 .1 \\
8.8 .1\end{array}$ \\
\hline $\begin{array}{l}\text { yarm } \\
\text { /ja:rm/ }\end{array}$ & $\begin{array}{l}\text { eärm } \\
\text { /ja:rm/ }\end{array}$ & $\begin{array}{l}\operatorname{arm} \\
\text { /a:m/ }\end{array}$ & $\begin{array}{l}7.21 .6 \\
8.8 .1\end{array}$ \\
\hline $\begin{array}{c}\text { i, ee } \\
/ \mathrm{I} /, / \mathrm{i}(\mathrm{i}) / \\
\text { kip, mit, sim, swit, } \\
\text { wik } \\
\text { keep, meet, seem, } \\
\text { sweet, week }\end{array}$ & $\begin{array}{c}\text { ee } \\
/ \mathrm{I} /, / \mathrm{i}(\mathrm{s}) / \\
\text { keep, meet, seem, } \\
\text { sweet, week }\end{array}$ & $\begin{array}{c}\text { ee } \\
\text { /i:/ } \\
\text { keep, meet, seem, } \\
\text { sweet, week }\end{array}$ & 7.10.11 \\
\hline $\begin{array}{l}\text { elem } \\
\text { / } \text { clom/ }\end{array}$ & $\begin{array}{l}\text { elem } \\
\text { /Eləm/ }\end{array}$ & $\begin{array}{l}\mathrm{elm} \\
/ \varepsilon \operatorname{lm} /\end{array}$ & 8.6 \\
\hline $\begin{array}{l}\text { èn, en (final) } \\
\text { /on/ } \\
\text { buildèn, doèn, } \\
\text { veedèn, zettèn, } \\
\text { zingèn, marnen, } \\
\text { woaken }\end{array}$ & $\begin{array}{l}\text { èn, en (final) } \\
\text { /ən/ } \\
\text { buildèn, doèn, } \\
\text { veedèn, zettèn, } \\
\text { zingèn, mornèn, } \\
\text { woaken }\end{array}$ & $\begin{array}{c}\text { ing, en (final) } \\
\text { /Iy/, /on/ } \\
\text { building, doing, } \\
\text { feeding, setting, } \\
\text { singing, morning, } \\
\text { oaken }\end{array}$ & $\begin{array}{l}7.1 .5 \\
8.4 .3\end{array}$ \\
\hline $\begin{array}{c}\text { er+C } \\
\text { /arr/ } \\
\text { herd, kern }\end{array}$ & $\begin{array}{c}\text { er+C } \\
\text { /arr/ } \\
\text { herd, kern }\end{array}$ & $\begin{array}{c}\text { er+C } \\
\text { /a:/ } \\
\text { herd, kern }\end{array}$ & $\begin{array}{l}7.9 .1 \\
8.8 .1\end{array}$ \\
\hline
\end{tabular}




\begin{tabular}{|c|c|c|c|}
\hline $\begin{array}{c}\text { eth } \\
/ \varepsilon \theta / \\
\text { eth, beth, meth }\end{array}$ & $\begin{array}{c}\text { e'th } \\
/ \varepsilon \theta / \\
\text { eth, beth, meth }\end{array}$ & $\begin{array}{c}\text { earth, irth } \\
\text { / }: \theta / \\
\text { earth, birth, mirth }\end{array}$ & $\begin{array}{l}7.9 .5 \mathrm{~d} \\
8.8 .5\end{array}$ \\
\hline $\begin{array}{l}\text { evemen } \\
\text { /iivmon/ }\end{array}$ & $\begin{array}{l}\text { evenèn } \\
\text { /i:vmən/ }\end{array}$ & $\begin{array}{l}\text { evening } \\
\text { /i:vnin/ }\end{array}$ & 8.7 .1 \\
\hline $\begin{array}{l}\text { fakket } \\
\text { /fakot/ }\end{array}$ & $\begin{array}{l}\text { faggot (fakket) } \\
\text { /fagot/,/fakət/ }\end{array}$ & $\begin{array}{l}\text { faggot } \\
\text { / fægat/ }\end{array}$ & 8.4 .2 \\
\hline $\begin{array}{l}\text { food } \\
\text { / fud/ }\end{array}$ & $\begin{array}{l}\text { food } \\
\text { / fud/ }\end{array}$ & $\begin{array}{l}\text { food } \\
\text { / fu:d/ }\end{array}$ & 7.6.2 \\
\hline $\begin{array}{c}\text { foüght, föwght } \\
\text { /fə:ut/ }\end{array}$ & $\begin{array}{l}\text { foüght } \\
\text { / fo:ut/ }\end{array}$ & $\begin{array}{l}\text { fought } \\
\text { / fo:t/ }\end{array}$ & 7.13.8c \\
\hline $\begin{array}{l}\text { ghiame } \\
\text { /gjem/ }\end{array}$ & $\begin{array}{l}\text { geäme } \\
\text { /gjem/ }\end{array}$ & $\begin{array}{l}\text { game } \\
\text { /germ/ }\end{array}$ & 8.4 .1 \\
\hline $\begin{array}{c}\text { giarden, ghiarden } \\
\text { /gjairdən/, } \\
\text { /giərdən/ }\end{array}$ & $\begin{array}{l}\text { geärden } \\
\text { /gja:rdən/ }\end{array}$ & $\begin{array}{l}\text { garden } \\
\text { /ga:dən/ }\end{array}$ & $\begin{array}{c}7.21 .2-3 \\
8.4 .1 \\
8.8 .1\end{array}$ \\
\hline $\begin{array}{c}\text { geät(e), ghiate } \\
\text { /giat/,/gjet/ }\end{array}$ & $\begin{array}{l}\text { geäte (geät) } \\
\text { /giat/,/gjet/ }\end{array}$ & $\begin{array}{l}\text { gate } \\
\text { /geit/ }\end{array}$ & $\begin{array}{l}7.11 .3 \\
8.4 .1\end{array}$ \\
\hline $\begin{array}{l}\text { gi'e } \\
\text { /gi:/ }\end{array}$ & $\begin{array}{l}\text { gi'e } \\
\text { /gi:/ }\end{array}$ & $\begin{array}{l}\text { give } \\
\text { /giv/ }\end{array}$ & $\begin{array}{l}7.1 .8 \\
8.15 .1\end{array}$ \\
\hline $\begin{array}{l}\text { gilcup, gil'cup } \\
\text { /gilkıp/ }\end{array}$ & $\begin{array}{l}\text { gil'cup (gilcup) } \\
\text { /gilkıp/ }\end{array}$ & $\begin{array}{l}\text { gilt-cup } \\
\text { /giltkıp/ }\end{array}$ & 8.4 .4 \\
\hline $\begin{array}{l}\text { girt } \\
\text { /gə:rt/ }\end{array}$ & $\begin{array}{l}\text { girt } \\
\text { /gəirt/ }\end{array}$ & $\begin{array}{l}\text { great } \\
\text { /greit/ }\end{array}$ & $\begin{array}{c}7.9 .4 \\
7.11 .11 \\
8.8 .3\end{array}$ \\
\hline $\begin{array}{l}\text { gnot } \\
\text { /nat/ }\end{array}$ & $\begin{array}{c}\text { gnot (gnat) } \\
/ \text { nat } /\end{array}$ & $\begin{array}{l}\text { gnat } \\
\text { /næt/ }\end{array}$ & 7.3.2 \\
\hline $\begin{array}{c}\text { goo, go } \\
\text { /gu: / }\end{array}$ & $\begin{array}{c}\text { goo (go) } \\
\text { /gu:/ (/go:/) }\end{array}$ & $\begin{array}{l}\text { go } \\
\text { /gov/ }\end{array}$ & 7.14 .6 \\
\hline $\begin{array}{l}\text { gookoo } \\
\text { /guku:/ }\end{array}$ & $\begin{array}{c}\text { goocoo, gookoo } \\
\text { /guku:/ }\end{array}$ & $\begin{array}{l}\text { cuckoo } \\
\text { /kuku:/ }\end{array}$ & 8.1 \\
\hline
\end{tabular}




\begin{tabular}{|c|c|c|c|}
\hline $\begin{array}{l}\text { goold } \\
\text { /guild/ }\end{array}$ & $\begin{array}{l}\text { goold } \\
\text { /guild/ }\end{array}$ & $\begin{array}{l}\text { gold } \\
\text { /gould/ }\end{array}$ & 7.14 .5 \\
\hline $\begin{array}{l}\text { gramfer } \\
\text { /gramfor/ }\end{array}$ & $\begin{array}{l}\text { gramfer } \\
\text { /gramfor/ }\end{array}$ & $\begin{array}{l}\text { grandfather } \\
\text { /græn(d)fa:ðə/ }\end{array}$ & 8.13 .2 \\
\hline $\begin{array}{l}\text { grammer } \\
\text { /gramor/ }\end{array}$ & $\begin{array}{l}\text { grammer } \\
\text { /gramər/ }\end{array}$ & $\begin{array}{l}\text { grandmother } \\
\text { /græn(d)m^ðə/ }\end{array}$ & 8.13 .2 \\
\hline $\begin{array}{l}\text { Grange } \\
\text { /gre:nd3/ }\end{array}$ & $\begin{array}{l}\text { Grange } \\
\text { /gre:nd3/ }\end{array}$ & $\begin{array}{l}\text { Grange } \\
\text { /greind3/ }\end{array}$ & 7.11 .12 \\
\hline $\begin{array}{l}\text { gwâin } \\
\text { /gwæin/ }\end{array}$ & $\begin{array}{l}\text { gwaïn } \\
\text { /gwæin/ }\end{array}$ & $\begin{array}{l}\text { going } \\
\text { /gouin/ }\end{array}$ & 7.14 .7 \\
\hline $\begin{array}{l}\text { ha' } \\
\text { /ha/ }\end{array}$ & $\begin{array}{l}\text { ha' } \\
\text { /ha/ }\end{array}$ & $\begin{array}{c}\text { has, have } \\
/ \text { hæz/, /hæv/ }\end{array}$ & 8.15 .1 \\
\hline $\begin{array}{c}\text { 'e (unstressed) } \\
/ \mathrm{\partial} /, / \mathrm{i}(\mathrm{s}) /\end{array}$ & $\begin{array}{l}\text { he (unstressed) } \\
/ \mathrm{o} /, / \mathrm{i}(\mathrm{i}) /, / \mathrm{hi} /\end{array}$ & $\begin{array}{l}\text { he } \\
\text { /hi:/ }\end{array}$ & 7.10 .1 \\
\hline $\begin{array}{l}\text { hear } \\
\text { /hior/ }\end{array}$ & $\begin{array}{c}\text { hear (heär) } \\
\text { /hiər/ }\end{array}$ & $\begin{array}{l}\text { hear } \\
\text { /hiə/ }\end{array}$ & $\begin{array}{c}7.19 .3 \\
8.5 .5 \\
8.8 .1\end{array}$ \\
\hline $\begin{array}{l}\text { heärd } \\
\text { /hiord/ }\end{array}$ & $\begin{array}{c}\text { heärd } \\
\text { /hiərd/, /hjərrd/ }\end{array}$ & $\begin{array}{l}\text { heard } \\
\text { /hə:d/ }\end{array}$ & $\begin{array}{c}7.9 .6 \\
7.19 .4 \\
8.5 .5 \\
8.8 .1\end{array}$ \\
\hline $\begin{array}{l}\text { here } \\
\text { /hior/ }\end{array}$ & $\begin{array}{l}\text { here } \\
\text { /hiər/ }\end{array}$ & $\begin{array}{l}\text { here } \\
\text { / hiə/ }\end{array}$ & $\begin{array}{c}7.19 .3 \\
8.5 .5 \\
8.8 .1\end{array}$ \\
\hline $\begin{array}{l}\text { het } \\
\text { /het/ }\end{array}$ & $\begin{array}{l}\text { het } \\
\text { /het/ }\end{array}$ & $\begin{array}{l}\text { heat } \\
\text { /hi:t/ }\end{array}$ & 7.10 .10 \\
\hline $\begin{array}{l}\text { heth } \\
/ \text { he } \theta /\end{array}$ & $\begin{array}{l}\text { he'th } \\
\text { /he } \theta /\end{array}$ & $\begin{array}{l}\text { hearth } \\
\text { /ha: } \theta /\end{array}$ & 7.21 .4 \\
\hline $\begin{array}{l}\text { hoss } \\
\text { /hps/ }\end{array}$ & $\begin{array}{l}\text { ho'se hoss } \\
\text { /hps/ }\end{array}$ & $\begin{array}{l}\text { horse } \\
\text { /ho:s/ }\end{array}$ & $\begin{array}{c}7.8 .4 \\
7.22 .4 \\
8.8 .5\end{array}$ \\
\hline
\end{tabular}




\begin{tabular}{|c|c|c|c|}
\hline $\begin{array}{l}\text { hovel } \\
\text { /h^vəl/ }\end{array}$ & $\begin{array}{l}\text { hovel } \\
\text { /h^val/ }\end{array}$ & $\begin{array}{c}\text { hovel } \\
\text { /hpvəl/,/h^vəl/ }\end{array}$ & 7.4.2 \\
\hline $\begin{array}{c}\overline{\mathbf{1}}, \mathbf{i}+\mathbf{C}+\mathbf{e}, \mathbf{i g h}(\text { etc.: } \\
\text { long } i) \\
\text { / ə:I/ } \\
\text { drìth, ice, eye, } \\
\text { height, light, smile, } \\
\text { try, vind }\end{array}$ & $\begin{array}{c}\mathbf{i}+\mathbf{C}+\mathbf{e}, \text { igh }(\text { etc.: } \\
\text { long } i) \\
\text { /ais/ } \\
\text { drith, ice, eye, } \\
\text { height, light, smile, } \\
\text { try, vind }\end{array}$ & $\begin{array}{c}\mathbf{i}+\mathbf{C}+\mathbf{e}, \mathbf{i g h}(\text { etc.: } \\
\text { long } i) \\
\text { /aI/ } \\
\text { dryness, ice, eye, } \\
\text { height, light, smile, } \\
\text { try, find }\end{array}$ & $\begin{array}{c}7.16 \\
7.16 .1\end{array}$ \\
\hline $\begin{array}{l}\text { idden } \\
\text { /Idən/ }\end{array}$ & $\begin{array}{l}\text { idden } \\
\text { /Idən/ }\end{array}$ & $\begin{array}{l}\text { isn't } \\
\text { /Izənt / }\end{array}$ & 8.9 .3 \\
\hline $\begin{array}{c}\text { ir+C } \\
\text { / } \mathrm{ar} / \\
\text { bird, dirt, shirt, stir }\end{array}$ & $\begin{array}{c}\text { ir+C } \\
\text { / } \mathrm{ar} / \\
\text { bird, dirt, shirt, stir }\end{array}$ & $\begin{array}{c}\text { ir+C } \\
\text { /ə:/ } \\
\text { bird, dirt, shirt, stir }\end{array}$ & $\begin{array}{l}7.9 .1 \\
8.8 .1\end{array}$ \\
\hline $\begin{array}{c}\text { ire, ier } \\
\text { /ə:Iər/ } \\
\text { vire, vier, squire, tire }\end{array}$ & $\begin{array}{c}\text { ire, ier } \\
\text { /ə:Iər/ } \\
\text { vire, vier, squire, tire }\end{array}$ & $\begin{array}{c}\text { ire } \\
\text { /aiə/ } \\
\text { fire, squire, tire }\end{array}$ & $\begin{array}{c}7.16 .2 \\
8.8 .1\end{array}$ \\
\hline $\begin{array}{c}\text { 'ithin, within } \\
\text { /(w)ıın/ }\end{array}$ & $\begin{array}{c}\text { 'ithin, within } \\
\text { /(w)rðIn } /\end{array}$ & $\begin{array}{l}\text { within } \\
\text { /wIðIn/ }\end{array}$ & 8.16 .1 \\
\hline $\begin{array}{c}\text { 'ithout, without } \\
\text { /(w)ıə:ut/ }\end{array}$ & $\begin{array}{c}\text { 'ithout, without } \\
\text { /(w)ґə:ut/ }\end{array}$ & $\begin{array}{l}\text { without } \\
\text { /wıðaut/ }\end{array}$ & 8.16 .1 \\
\hline $\begin{array}{c}\text { jây } \\
\text { /dzæa/ }\end{array}$ & $\begin{array}{c}\text { jä̈ } \\
/ \text { dzæI/ }\end{array}$ & $\begin{array}{l}\text { joy } \\
\text { /dzoI/ }\end{array}$ & 7.17.3 \\
\hline $\begin{array}{c}\text { jis', jist, just } \\
\text { /dzIs/, /dzist/, } \\
\text { /dzムst/ }\end{array}$ & $\begin{array}{c}\text { jist, just (jis', jus') } \\
\text { /d } \mathrm{d}_{\mathrm{ISt}} /, / \mathrm{d}_{3} \Lambda \mathrm{st} / \\
/ \mathrm{d}_{3} \mathrm{IS} /, / \mathrm{d}_{3} \Lambda \mathrm{s} /\end{array}$ & $\begin{array}{c}\text { just } \\
/ \mathrm{d}_{3} \wedge \mathrm{st} /\end{array}$ & 7.5.6 \\
\hline $\begin{array}{c}\text { Jahn, John } \\
\text { /dzan } /\end{array}$ & $\begin{array}{c}\text { John (Jahn) } \\
/ \mathrm{d}_{3} \mathrm{an} /\end{array}$ & $\begin{array}{l}\text { John } \\
\text { /dzpn/ }\end{array}$ & 7.4 \\
\hline $\begin{array}{l}\text { laid } \\
/ 1 \varepsilon d /\end{array}$ & $\begin{array}{l}\text { laid } \\
/ 1 \varepsilon d /\end{array}$ & $\begin{array}{l}\text { laid } \\
\text { /lerd/ }\end{array}$ & 7.11.7 \\
\hline $\begin{array}{c}\text { lāste, laste, lēste } \\
/ 1 \text { : :st } /\end{array}$ & $\begin{array}{l}\text { laste } \\
\text { /le:st/ }\end{array}$ & $\begin{array}{l}\text { last } \\
\text { /la:st/ }\end{array}$ & 7.7.4 \\
\hline $\begin{array}{l}\text { lather } \\
\text { /laðər/ }\end{array}$ & $\begin{array}{l}\text { lather } \\
\text { /laðər/ }\end{array}$ & $\begin{array}{l}\text { ladder } \\
\text { /lædər/ }\end{array}$ & $\begin{array}{l}8.2 .3 \\
8.8 .1\end{array}$ \\
\hline
\end{tabular}




\begin{tabular}{|c|c|c|c|}
\hline $\begin{array}{c}\text { lik' (adv., past tense) } \\
\text { /lik/ }\end{array}$ & $\begin{array}{c}\text { lik', like }(a d v ., \text { past } \\
\text { tense }) \\
/ \text { I }_{\mathbf{~}} /\end{array}$ & $\begin{array}{l}\text { like } \\
\text { /laık/ }\end{array}$ & 7.16 .5 \\
\hline $\begin{array}{c}\text { lo'k, look } \\
\text { /luk/ }\end{array}$ & $\begin{array}{c}\text { look, (lo'k) } \\
\text { /luk/ }\end{array}$ & $\begin{array}{l}\text { look } \\
\text { /luk/ }\end{array}$ & 7.6 .5 \\
\hline $\begin{array}{c}\text { meäd } \\
/ \mathrm{miəd} /, / \mathrm{mi} \mathrm{d} /, \\
/ \mathrm{mj} \varepsilon \mathrm{d} /\end{array}$ & $\begin{array}{c}\text { meäd } \\
/ \operatorname{miəd} /, / \text { mi:d } /, \\
/ \operatorname{mj} \varepsilon d /\end{array}$ & $\begin{array}{l}\text { mead } \\
/ \mathrm{mild} /\end{array}$ & 7.11 .3 \\
\hline $\begin{array}{l}\text { miaster } \\
\text { /mjaistər/ }\end{array}$ & $\begin{array}{l}\text { meäster } \\
\text { /mjaistər/ }\end{array}$ & $\begin{array}{l}\text { master } \\
\text { /maistə/ }\end{array}$ & $\begin{array}{l}7.7 .3 \\
8.8 .1\end{array}$ \\
\hline $\begin{array}{c}\min (\text { 'mate') } \\
/ \mathrm{min} /\end{array}$ & $\begin{array}{c}\min (\text { 'mate') } \\
/ \mathrm{min} /\end{array}$ & & 7.1 .6 \\
\hline $\begin{array}{c}\text { moot ('tree-stump') } \\
\text { / mut } /\end{array}$ & $\begin{array}{c}\text { moot ('tree-stump') } \\
\text { /mut }\end{array}$ & $\begin{array}{c}\text { moot ('tree-stump') } \\
\text { /muit } /\end{array}$ & 7.6 .2 \\
\hline $\begin{array}{c}\text { moorn } \\
\text { /mo:rn/,/muərn/ }\end{array}$ & $\begin{array}{l}\text { murn } \\
\text { /mo:rn/ }\end{array}$ & $\begin{array}{l}\text { mourn } \\
/ \text { mo:n/ }\end{array}$ & $\begin{array}{l}7.9 .7 \\
7.23 .5\end{array}$ \\
\hline $\begin{array}{l}\text { nâise } \\
\text { /næiz/ }\end{array}$ & $\begin{array}{l}\text { naïse } \\
\text { /næız/ }\end{array}$ & $\begin{array}{l}\text { noise } \\
\text { /norz/ }\end{array}$ & 7.17 .2 \\
\hline $\begin{array}{c}\text { noo ('not any’) } \\
\text { /nu: }\end{array}$ & $\begin{array}{c}\text { noo ('not any’) } \\
\text { /nu: }\end{array}$ & $\begin{array}{c}\text { no } \\
/ \text { nov/ }\end{array}$ & 7.14 .6 \\
\hline $\begin{array}{c}\text { nuone } \\
/ \text { nunn/,/nuon/ }\end{array}$ & $\begin{array}{c}\text { nwone } \\
/ \text { nunn/,/nuon/ }\end{array}$ & $\begin{array}{l}\text { none } \\
/ \mathrm{n} \wedge \mathrm{n} /\end{array}$ & 7.5 .8 \\
\hline $\begin{array}{l}\mathbf{o}^{\prime} \\
/ 2 /\end{array}$ & $\begin{array}{l}\mathbf{o}^{\prime} \\
/ \partial /\end{array}$ & $\begin{array}{c}\text { of } \\
/ \mathrm{pv} /, / \mathrm{ov} /\end{array}$ & 8.3 .2 \\
\hline $\begin{array}{c}\text { a, o } \\
\text { /a/ } \\
\text { drap, Jahn, John, } \\
\text { beyand, beyond, } \\
\text { yander }\end{array}$ & $\begin{array}{c}\text { o, a } \\
/ \mathrm{a} /, / \mathrm{p} / \\
\text { drop (drap), John } \\
\text { (Jahn), beyond } \\
\text { (beyand), yonder } \\
\text { (yander) }\end{array}$ & $\begin{array}{c}\mathbf{o} \\
/ \mathrm{p} / \\
\text { drop, John, beyond, } \\
\text { yonder }\end{array}$ & 7.4 \\
\hline
\end{tabular}




\begin{tabular}{|c|c|c|c|}
\hline $\begin{array}{c}\text { o, oa, o+C+e } \\
\text { /o:/ } \\
\text { broke, coal, hole, } \\
\text { poll, stole, voke, } \\
\text { vo'ke }\end{array}$ & $\begin{array}{c}\text { o, oa, o+C+e } \\
\text { /o:/ } \\
\text { broke, coal, hole, } \\
\text { poll, stole, vo'ke }\end{array}$ & $\begin{array}{c}\text { o, oa, o+C+e } \\
\text { /əu/ } \\
\text { broke, coal, hole, } \\
\text { poll, stole, folk }\end{array}$ & 7.14.1-2 \\
\hline $\begin{array}{c}\overline{\mathbf{o}}^{\prime} \mathrm{m}, \overline{\mathbf{o}} \mathbf{n}, \overline{\mathbf{o}} \mathbf{s}, \overline{\mathbf{o}}^{\prime} \mathbf{t} \\
\text { /o:m/, /o:n/, /o:s/, } \\
\text { /o:t/ }\end{array}$ & 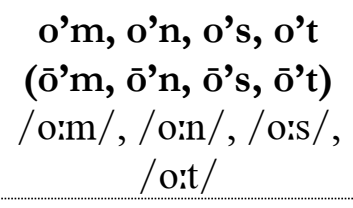 & $\begin{array}{c}\text { of 'em, of 'im, of } \\
\text { us, of it } \\
\text { /pv əm/, /pv Im/, } \\
\text { /pv əs/,/pv it/ }\end{array}$ & 8.3 .3 \\
\hline $\begin{array}{l}\text { oben } \\
\text { /o:bon/ }\end{array}$ & $\begin{array}{c}\text { oben, open } \\
\text { /o:bon/, /o:pon/ }\end{array}$ & $\begin{array}{l}\text { open } \\
\text { /oupon/ }\end{array}$ & 8.7 .3 \\
\hline $\begin{array}{l}\operatorname{ar}(\text { final) } \\
\text { /a:r/, /ar/, /or/ } \\
\text { ar, var, nar }\end{array}$ & $\begin{array}{l}\text { or (final) } \\
\text { /arr/, /ar/, /or/ } \\
\text { or, vor (for), nor }\end{array}$ & $\begin{array}{l}\text { or (final) } \\
\text { /o:/,/ə/ } \\
\text { or, for, nor }\end{array}$ & $\begin{array}{l}7.22 .3 \\
8.8 .1\end{array}$ \\
\hline $\begin{array}{c}\text { ar (medial) } \\
\text { /arr/ } \\
\text { carn, fark, lard, } \\
\text { marnen, archet, } \\
\text { shart, starm }\end{array}$ & $\begin{array}{c}\text { or (medial) } \\
\text { /arr/ } \\
\text { corn, fork, lord, } \\
\text { mornèn, orcha'd, } \\
\text { short, storm }\end{array}$ & $\begin{array}{c}\text { or (medial) } \\
\text { /o:/ } \\
\text { corn, fork, lord, } \\
\text { morning, orchard, } \\
\text { short, storm }\end{array}$ & $\begin{array}{l}7.22 .1 \\
8.8 .1\end{array}$ \\
\hline $\begin{array}{c}\text { or+C } \\
\text { /orr/ } \\
\text { word, work, worthy }\end{array}$ & $\begin{array}{c}\text { or+C } \\
\text { / orr/ } \\
\text { word, work, worthy }\end{array}$ & $\begin{array}{c}\text { or+C } \\
\text { /ə:/ } \\
\text { word, work, worthy }\end{array}$ & $\begin{array}{l}7.9 .1 \\
8.8 .1\end{array}$ \\
\hline $\begin{array}{l}\text { archet } \\
\text { /arrt」ət/ }\end{array}$ & 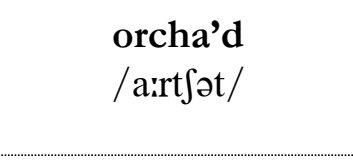 & 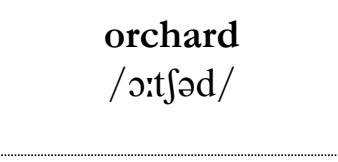 & $\begin{array}{c}7.22 .1 \\
8.2 .4 \\
8.8 .7\end{array}$ \\
\hline $\begin{array}{c}\text { ore, uore, our } \\
\text { /uər/ } \\
\text { bevore, bore, } \\
\text { m(u)ore, court }\end{array}$ & $\begin{array}{c}\text { ore, uore, our } \\
\text { /uər/ } \\
\text { bevore, bore, } \\
\text { mwore, fourth }\end{array}$ & $\begin{array}{c}\text { or, ore, our } \\
\text { /o:/ } \\
\text { before, bore, more, } \\
\text { court, fourth }\end{array}$ & $\begin{array}{l}7.23 .1 \\
8.8 .1\end{array}$ \\
\hline $\begin{array}{c}\text { ou, ow } \\
\text { /o:u/ } \\
\text { bough, cloud, } \\
\text { groun', house, out, } \\
\text { cow, how, now, } \\
\text { down }\end{array}$ & $\begin{array}{c}\text { ou, ow } \\
\text { /əu/ } \\
\text { bough, cloud, } \\
\text { groun(d), house, } \\
\text { out, cow, how, now, } \\
\text { down }\end{array}$ & $\begin{array}{c}\text { ou, ow } \\
\text { /au/ } \\
\text { bough, cloud, } \\
\text { ground, house, out, } \\
\text { cow, how, now, } \\
\text { down }\end{array}$ & 7.18 .1 \\
\hline
\end{tabular}




\begin{tabular}{|c|c|c|c|}
\hline $\begin{array}{c}\text { our, ower, ow'r } \\
\text { / oruər/ } \\
\text { our, hour, flower, } \\
\text { flow'r, shower, } \\
\text { show'r, tower }\end{array}$ & $\begin{array}{c}\text { our, ower, ow'r } \\
\text { / o:uər/ } \\
\text { our, hour, flower, } \\
\text { flow'r, shower, } \\
\text { show'r, tower, tow'r }\end{array}$ & $\begin{array}{c}\text { our, ower } \\
\text { /auə/ } \\
\text { our, hour, flower, } \\
\text { shower, tower }\end{array}$ & $\begin{array}{l}7.18 .2 \\
8.8 .1\end{array}$ \\
\hline $\begin{array}{c}\text { oust, ust } \\
\text { /o:ust/, / } \mathrm{st} / \\
\text { crust, doust, dust }\end{array}$ & $\begin{array}{c}\text { oust (ust) } \\
\text { / orust/, / } \Lambda \text { st/ } \\
\text { crust, doust, dust }\end{array}$ & $\begin{array}{c}\text { ust } \\
/ \Lambda \mathrm{st} / \\
\text { crust, dust }\end{array}$ & 7.5 .5 \\
\hline $\begin{array}{c}\text { out } \\
\text { /o'ut/ } \\
\text { rout, strout, astrout }\end{array}$ & $\begin{array}{c}\text { out } \\
\text { /o:ut/ } \\
\text { rout, strout, a-strout }\end{array}$ & $\begin{array}{c}\text { ut } \\
/ \Lambda \mathrm{t} / \\
\text { rut, strut, a-strut }\end{array}$ & 7.5 .4 \\
\hline 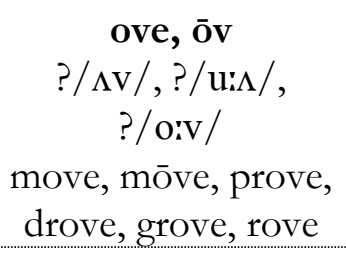 & 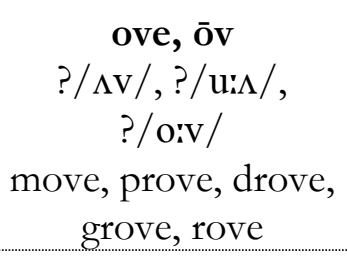 & $\begin{array}{c}\text { ove } \\
\text { /ui } \Lambda /, / \text { / } \Lambda \Lambda / \\
\text { move, prove, drove, } \\
\text { grove, rove }\end{array}$ & 7.5 .3 \\
\hline $\begin{array}{l}\text { auver } \\
\text { /orvor/ }\end{array}$ & $\begin{array}{c}\text { over } \\
\text { /orvor/ }\end{array}$ & $\begin{array}{l}\text { over } \\
\text { /ouvə/ }\end{array}$ & $\begin{array}{c}7.14 .10 \\
8.8 .1\end{array}$ \\
\hline $\begin{array}{l}\text { er (final, unstressed) } \\
\text { /ə(r)/ } \\
\text { feller, holler, shaller, } \\
\text { winder, yaller, } \\
\text { yoller, zwaller }\end{array}$ & $\begin{array}{c}\text { ow (final, unstressed) } \\
\text { /ə(r)/ } \\
\text { fellow, hollow, } \\
\text { shallow, window, } \\
\text { yellow, yollow, } \\
\text { zwallow }\end{array}$ & $\begin{array}{c}\text { ow (final, unstressed) } \\
\text { /ou/ } \\
\text { fellow, hollow, } \\
\text { shallow, window, } \\
\text { yellow, swallow }\end{array}$ & $\begin{array}{l}7.14 .8 \\
8.8 .2\end{array}$ \\
\hline $\begin{array}{l}\text { pank } \\
/ \text { pank/ }\end{array}$ & $\begin{array}{l}\text { pank (pant) } \\
/ \text { pank/ }\end{array}$ & $\begin{array}{l}\text { pant } \\
\text { /pænt/ }\end{array}$ & 8.12 .2 \\
\hline $\begin{array}{l}\text { parrick } \\
\text { /parik/ }\end{array}$ & $\begin{array}{c}\text { parrock (parrick) } \\
/ \text { parik } /\end{array}$ & $\begin{array}{l}\text { paddock } \\
\text { /pædək/ }\end{array}$ & 8.2 .1 \\
\hline $\begin{array}{l}\text { piart } \\
\text { /pjarrt/ }\end{array}$ & $\begin{array}{l}\text { peärt } \\
\text { /pja:rt/ }\end{array}$ & $\begin{array}{l}\text { part } \\
\text { /pa:t/ }\end{array}$ & $\begin{array}{l}7.21 .2 \\
8.8 .1\end{array}$ \\
\hline $\begin{array}{c}\text { poor } \\
/ \mathrm{pu}(\mathrm{s}) \partial \mathrm{r} /\end{array}$ & $\begin{array}{l}\text { poor } \\
/ \mathrm{pu}(\mathrm{s}) \partial \mathrm{r} /\end{array}$ & $\begin{array}{c}\text { poor } \\
/ \text { po:/,/puə/ }\end{array}$ & $\begin{array}{l}7.24 .1 \\
8.8 .1\end{array}$ \\
\hline
\end{tabular}




\begin{tabular}{|c|c|c|c|}
\hline $\begin{array}{l}\text { pirty } \\
\text { /porti/ }\end{array}$ & $\begin{array}{c}\text { pretty, perty } \\
\text { (pirty) } \\
\text { /porti/ }\end{array}$ & $\begin{array}{l}\text { pretty } \\
\text { /priti/ }\end{array}$ & $\begin{array}{l}7.9 .4 \\
8.8 .3\end{array}$ \\
\hline $\begin{array}{l}\text { pwison } \\
\text { /pwə:Izən/ }\end{array}$ & $\begin{array}{l}\text { pweison } \\
\text { (pwoison) } \\
\text { /pwəizən/ }\end{array}$ & $\begin{array}{l}\text { poison } \\
\text { /porzən/ }\end{array}$ & $\begin{array}{l}7.17 .1 \\
8.16 .3\end{array}$ \\
\hline $\begin{array}{l}\text { quâits } \\
/ \mathrm{k}(\mathrm{w}) \mathfrak{\text { Its }} /\end{array}$ & $\begin{array}{c}\text { quaïts } \\
/ \mathrm{k}(\mathrm{w}) æ \mathrm{Its} /\end{array}$ & $\begin{array}{c}\text { quoits } \\
/ \mathrm{k}(\mathrm{w}) \text { ○ts / }\end{array}$ & 7.17.2 \\
\hline $\begin{array}{l}\text { quarrel } \\
\text { /kwarəl/ }\end{array}$ & $\begin{array}{c}\text { quarrel } \\
\text { /kwarəl/,/kwarəl/ }\end{array}$ & $\begin{array}{l}\text { quarrel } \\
\text { /kwbrəl/ }\end{array}$ & 7.22.5 \\
\hline $\begin{array}{c}\mathbf{r} \\
/ \mathrm{r} / \text { (always } \\
\text { sounded) }\end{array}$ & $\begin{array}{l}\quad \mathbf{r} \\
/ \mathbf{r} / \text { (always } \\
\text { sounded) }\end{array}$ & $\begin{array}{l}\mathbf{r} \\
/ \mathrm{r} / \text { (mute before a } \\
\text { consonant or at the } \\
\text { end of a word) }\end{array}$ & 8.8 .1 \\
\hline $\begin{array}{l}\text { rear } \\
\text { /rear/ }\end{array}$ & $\begin{array}{l}\text { rear } \\
\text { /reor/ }\end{array}$ & $\begin{array}{l}\text { rear } \\
\text { /ria/ }\end{array}$ & $\begin{array}{c}7.19 .5 \\
8.8 .1\end{array}$ \\
\hline $\begin{array}{l}\text { rejâice } \\
\text { /ridzæis/ }\end{array}$ & $\begin{array}{l}\text { rejaïce } \\
\text { /ridzæis/ }\end{array}$ & $\begin{array}{l}\text { rejoice } \\
\text { /ridzoIs/ }\end{array}$ & 7.17.2 \\
\hline $\begin{array}{l}\text { rudge } \\
/ \mathrm{r} \wedge \mathrm{d} 3 /\end{array}$ & $\begin{array}{c}\text { ridge (rudge) } \\
/ \mathrm{r} \wedge \mathrm{d}_{3} /\end{array}$ & $\begin{array}{l}\text { ridge } \\
\text { /rid3/ }\end{array}$ & 7.1.4a \\
\hline $\begin{array}{c}\text { rdle } \\
\text { /[ə:]rdəl/ } \\
\text { curdle, twirdle, } \\
\text { whirdle }\end{array}$ & $\begin{array}{c}\text { rl, rrel } \\
\text { /[ə:]r[ə]1/, /[ə:]rdəl/ } \\
\text { curl (currel), twirl, } \\
\text { whirl }\end{array}$ & $\begin{array}{c}\mathbf{r l} \\
/[ə:] 1 / \\
\text { curl, twirl, whirl }\end{array}$ & 8.8 .4 \\
\hline $\begin{array}{l}\text { ruf } \\
/ \mathrm{r} \Delta \mathrm{f} /\end{array}$ & $\begin{array}{l}\operatorname{ruf}(\text { roof) } \\
\quad / \mathrm{r} \wedge \mathrm{f} /\end{array}$ & $\begin{array}{l}\text { roof } \\
\text { /ruif/ }\end{array}$ & 7.5.2 \\
\hline $\begin{array}{l}\text { sass } \\
\text { /sa:s/ }\end{array}$ & $\begin{array}{l}\text { sa's, sauce } \\
\quad / \text { sa:s/ }\end{array}$ & $\begin{array}{l}\text { sauce } \\
\text { /so:s/ }\end{array}$ & 7.13 .3 \\
\hline $\begin{array}{l}\text { sar } \\
/ \text { sa:r/ }\end{array}$ & $\begin{array}{l}\text { sar } \\
\text { /sa:r/ }\end{array}$ & $\begin{array}{l}\text { serve } \\
\text { /so:v/ }\end{array}$ & $\begin{array}{l}7.9 .2 \\
8.15 .1\end{array}$ \\
\hline $\begin{array}{l}\text { sheen } \\
/ \text { Si:n/ }\end{array}$ & $\begin{array}{l}\text { sheen } \\
/ \text { /inn/ }\end{array}$ & $\begin{array}{l}\text { shine } \\
\text { / Sain/ }\end{array}$ & 7.10 .2 \\
\hline
\end{tabular}




\begin{tabular}{|c|c|c|c|}
\hline $\begin{array}{c}\text { shoot } \\
/ \text { sut } /, / \text { su:t } /\end{array}$ & $\begin{array}{c}\text { shoot } \\
\text { / Sut/,/Su:t/ }\end{array}$ & $\begin{array}{l}\text { shoot } \\
\text { / Suit/ }\end{array}$ & 7.6.3 \\
\hline $\begin{array}{l}\text { Shodon } \\
\text { / pdon/ }\end{array}$ & $\begin{array}{c}\text { Shroton (Sho'ton) } \\
\text { / } \text { pdən/ }\end{array}$ & $\begin{array}{l}\text { Shroton } \\
\text { / } \text { roton/ }\end{array}$ & 8.11 \\
\hline $\begin{array}{l}\text { sich, such } \\
/ \text { sit } /, / \text { s } \Delta t 5 /\end{array}$ & $\begin{array}{l}\text { sich, such } \\
/ \text { sit } / \text { /,/s } \Delta \text { t } \int /\end{array}$ & $\begin{array}{l}\text { such } \\
/ \text { s } \Delta \mathrm{t} S /\end{array}$ & 7.5.6 \\
\hline $\begin{array}{l}\text { skia'ce } \\
\text { /skjes/ }\end{array}$ & $\begin{array}{l}\text { skeä'ce } \\
\text { /skjes/ }\end{array}$ & $\begin{array}{l}\text { scarce } \\
\text { /skeəs/ }\end{array}$ & $\begin{array}{c}7.20 .4 \\
8.8 .5 \\
\end{array}$ \\
\hline $\begin{array}{l}\text { sloo } \\
\text { /slu:/ }\end{array}$ & $\begin{array}{l}\text { sloo } \\
\text { /slu:/ }\end{array}$ & $\begin{array}{l}\text { sloe } \\
\text { /slov/ }\end{array}$ & 7.14 .6 \\
\hline $\begin{array}{l}\text { sloth } \\
/ \operatorname{sln} \theta /\end{array}$ & $\begin{array}{l}\text { sloth } \\
/ \operatorname{sln} \theta /\end{array}$ & $\begin{array}{l}\text { sloth } \\
\text { /sləu } \theta /\end{array}$ & 7.14 .13 \\
\hline $\begin{array}{c}\text { sate, soft } \\
/ \text { sc:t/,/spft/ }\end{array}$ & $\begin{array}{c}\text { soft } \\
/ \mathrm{se}: \mathrm{t} /, / \mathrm{spft} /\end{array}$ & $\begin{array}{l}\text { soft } \\
\text { /spft/ }\end{array}$ & 7.8 .5 \\
\hline $\begin{array}{c}\text { sarra } \\
\text { /sa(:)rə/,/sarə/ }\end{array}$ & $\begin{array}{c}\text { sorrow } \\
\text { /sa(:)rə/,/sarə/ }\end{array}$ & $\begin{array}{l}\text { sorrow } \\
\text { /sprou/ }\end{array}$ & 7.22 .5 \\
\hline $\begin{array}{l}\text { spiarde } \\
\text { /spja:rd/ }\end{array}$ & $\begin{array}{l}\text { speäde } \\
\text { /spjed/ }\end{array}$ & $\begin{array}{l}\text { spade } \\
\text { /speid/ }\end{array}$ & $\begin{array}{l}7.21 .2 \\
8.8 .1\end{array}$ \\
\hline $\begin{array}{l}\text { speer } \\
\text { /spior/ }\end{array}$ & $\begin{array}{l}\text { speer } \\
\text { /spiar/ }\end{array}$ & $\begin{array}{l}\text { spire } \\
\text { /spara/ }\end{array}$ & $\begin{array}{c}7.16 .3 \\
8.8 .1\end{array}$ \\
\hline $\begin{array}{l}\text { spwile } \\
\text { /spwə:Il/ }\end{array}$ & $\begin{array}{l}\text { spweil } \\
\text { /spwə:Il/ }\end{array}$ & $\begin{array}{l}\text { spoil } \\
\text { /sporl/ }\end{array}$ & $\begin{array}{l}7.17 .1 \\
8.16 .3\end{array}$ \\
\hline $\begin{array}{l}\text { squerrel } \\
\text { /skwə:rəl/ }\end{array}$ & $\begin{array}{l}\text { squirrel } \\
\text { /skwərrəl/ }\end{array}$ & $\begin{array}{l}\text { squirrel } \\
\text { /skwirəl/ }\end{array}$ & 7.1 .9 \\
\hline $\begin{array}{l}\text { strik, strik' } \\
\text { /strik/ }\end{array}$ & $\begin{array}{c}\text { strik, strik', strike } \\
\text { /strik/ }\end{array}$ & $\begin{array}{l}\text { strike } \\
\text { /straik/ }\end{array}$ & 7.16 .5 \\
\hline $\begin{array}{c}\text { sure } \\
/ \int \mathrm{u}(:) \partial r /\end{array}$ & $\begin{array}{c}\text { sure } \\
/ \int \mathrm{u}(:) \partial r /\end{array}$ & $\begin{array}{c}\text { sure } \\
/ \text { So:/, / / Uo/ }\end{array}$ & $\begin{array}{c}7.24 .1 \\
8.8 .1\end{array}$ \\
\hline
\end{tabular}




\begin{tabular}{|c|c|c|c|}
\hline $\begin{array}{c}\text { th (voiced) } \\
\text { /ð/ } \\
\text { tharn, thatch, thin, } \\
\text { thing, think, athirt, } \\
\text { thissle, thought }(v .)\end{array}$ & $\begin{array}{c}\text { th }(\text { voiced }) \\
/ \text { /ठ } \\
\text { thorn, thatch, thin, } \\
\text { thing, think, } \\
\text { athwart, thistle, } \\
\text { thought }(v .)\end{array}$ & $\begin{array}{c}\text { th }(\text { voiceless }) \\
/ \theta / \\
\text { thorn, thatch, thin, } \\
\text { thing, think, } \\
\text { athwart, thistle, } \\
\text { thought }\end{array}$ & 8.13 .1 \\
\hline $\begin{array}{l}\text { theös } \\
\text { /ðiəs/ }\end{array}$ & $\begin{array}{l}\text { theäse } \\
\text { /ðiəs/ }\end{array}$ & $\begin{array}{l}\text { this } \\
\text { /ðIS/ }\end{array}$ & 7.10 .9 \\
\hline $\begin{array}{l}\text { ther, their } \\
\text { /ðər/,/ðعər/ }\end{array}$ & $\begin{array}{l}\text { their (ther) } \\
\text { /ðər/,/ðعər/ }\end{array}$ & $\begin{array}{l}\text { their } \\
\text { /ðعə/ }\end{array}$ & $\begin{array}{l}7.20 .3 \\
8.8 .1\end{array}$ \\
\hline $\begin{array}{l}\text { vlee, vlees } \\
\text { /vli:/, /vli:z/ }\end{array}$ & $\begin{array}{l}\text { vlee, vlees } \\
\text { /vli:/,/vli:z/ }\end{array}$ & $\begin{array}{c}\text { fly, flies } \\
\text { /flai/, / flaiz/ }\end{array}$ & 7.16 .6 \\
\hline $\begin{array}{c}\text { vlour } \\
\text { /vluər/,?/vləruər/ }\end{array}$ & $\begin{array}{l}\text { vloor } \\
\text { /vluor/ }\end{array}$ & $\begin{array}{l}\text { floor } \\
\text { /flo:/ }\end{array}$ & $\begin{array}{l}7.23 .3 \\
8.8 .1\end{array}$ \\
\hline $\begin{array}{l}\text { vust } \\
\text { /vast/ }\end{array}$ & $\begin{array}{l}\text { vu'st } \\
\text { /vast/ }\end{array}$ & $\begin{array}{c}\text { first } \\
\text { /farst/ }\end{array}$ & $\begin{array}{l}7.9 .5 c \\
8.8 .5\end{array}$ \\
\hline $\begin{array}{l}\text { vuzz } \\
\text { /vız/ }\end{array}$ & $\begin{array}{l}\text { vuzz } \\
\text { /vız/ }\end{array}$ & $\begin{array}{l}\text { furze } \\
\text { /fə:z/ }\end{array}$ & $\begin{array}{l}7.9 .5 \mathrm{f} \\
8.8 .5\end{array}$ \\
\hline $\begin{array}{l}\text { wages } \\
\text { /we:dzIz/ }\end{array}$ & $\begin{array}{c}\text { wages } \\
\text { /we:dzIz/ }\end{array}$ & $\begin{array}{l}\text { wages } \\
\text { / weIdzIz/ }\end{array}$ & 7.11 .13 \\
\hline $\begin{array}{c}\text { way, woy } \\
\text { /we:/, /wa:I/, } \\
\text { /wæi/ }\end{array}$ & $\begin{array}{c}\text { way, waÿ, woy } \\
\text { /we:/, /wæi/, } \\
\text { /wə: / }\end{array}$ & $\begin{array}{l}\text { way } \\
\text { /weI/ }\end{array}$ & 7.11 .8 \\
\hline $\begin{array}{c}\text { wēak, weak } \\
\text { /we:k/,/wi:k/ }\end{array}$ & $\begin{array}{l}\text { weak (weäk) } \\
\text { /we:k/,/wiək/ }\end{array}$ & $\begin{array}{l}\text { weak } \\
\text { /wi:k/ }\end{array}$ & 7.10 .14 \\
\hline $\begin{array}{c}\text { weir } \\
\text { /weər/ }\end{array}$ & $\begin{array}{c}\text { weir } \\
\text { /weər/ }\end{array}$ & $\begin{array}{l}\text { weir } \\
\text { /wiə/ }\end{array}$ & $\begin{array}{c}7.19 .5 \\
8.8 .1\end{array}$ \\
\hline $\begin{array}{c}\text { wher, where } \\
\text { /(h)wor/,/(h)weər/ }\end{array}$ & $\begin{array}{c}\text { wher, where } \\
\text { /(h)wor/,/(h)weər/ }\end{array}$ & $\begin{array}{l}\text { where } \\
\text { /(h)weə/ }\end{array}$ & $\begin{array}{c}7.20 .3 \\
8.8 .1\end{array}$ \\
\hline $\begin{array}{c}\text { whirdle } \\
\text { /(h)wə:rdəl/ }\end{array}$ & $\begin{array}{l}\text { whirl } \\
\text { /(h)wə:rl/, } \\
\text { /(h)wə:rdəl/ }\end{array}$ & $\begin{array}{l}\text { whirl } \\
\text { /(h)wə:l/ }\end{array}$ & $\begin{array}{l}8.5 .3 \\
8.8 .4\end{array}$ \\
\hline
\end{tabular}




\begin{tabular}{|c|c|c|c|}
\hline $\begin{array}{l}\text { huosse } \\
\text { /huəs/ }\end{array}$ & $\begin{array}{l}\text { whoa'se } \\
\text { /huəs/ }\end{array}$ & $\begin{array}{l}\text { hoarse } \\
\text { /ho:s/ }\end{array}$ & 7.23.6a \\
\hline $\begin{array}{l}\text { wi' } \\
\text { /wi/ }\end{array}$ & $\begin{array}{l}\text { wi' } \\
\text { /wi/ }\end{array}$ & $\begin{array}{l}\text { with } \\
\text { /wıð/ }\end{array}$ & $\begin{array}{l}7.1 .7 \\
8.13 .2\end{array}$ \\
\hline $\begin{array}{c}\text { wo, woa (initial) } \\
/(\text { w)uə/ } \\
\text { wold, woak, woats, } \\
\text { woath }\end{array}$ & $\begin{array}{c}\text { wo, woa (initial) } \\
/(\text { w)uə/ } \\
\text { wold, woak, woats, } \\
\text { woath }\end{array}$ & $\begin{array}{c}\text { o, oa (initial) } \\
/ \text { ov/ } \\
\text { old, oak, oats, oath }\end{array}$ & 7.14 .4 \\
\hline $\begin{array}{c}\text { uo, uoa, uo+C+e } \\
\text { / uə/ } \\
\text { buold, cuomb, } \\
\text { huome, luoad, luoaf, } \\
\text { ruope, stuone }\end{array}$ & $\begin{array}{c}\text { wo, woa, wo+C+e } \\
\text { /uə/ } \\
\text { bwold, cwomb, } \\
\text { hwome, lwoad, } \\
\text { lwoaf, rwope, } \\
\text { stwone }\end{array}$ & $\begin{array}{c}\text { o, oa, o+C+e } \\
\text { /ov/ } \\
\text { bold, comb, home, } \\
\text { load, loaf, rope, } \\
\text { stone }\end{array}$ & 7.14.1-3 \\
\hline $\begin{array}{l}\text { wust } \\
\text { /w } \Lambda \text { st/ }\end{array}$ & $\begin{array}{c}\text { wo'st (worst) } \\
\text { /w } \Lambda \text { st } /\end{array}$ & $\begin{array}{l}\text { worst } \\
\text { /warst/ }\end{array}$ & $\begin{array}{l}7.9 .5 \mathrm{c} \\
8.8 .5\end{array}$ \\
\hline $\begin{array}{c}\text { wo'th } \\
\text { /woth/, /wsth/ }\end{array}$ & $\begin{array}{c}\text { wo'th } \\
\text { /woth/, /w } \Delta \text { th/ }\end{array}$ & $\begin{array}{l}\text { worth } \\
\text { /wə: } \theta /\end{array}$ & $\begin{array}{l}7.9 .5 \mathrm{e} \\
8.8 .5\end{array}$ \\
\hline $\begin{array}{c}\text { women } \\
\text { /womin/,/wumin/ }\end{array}$ & $\begin{array}{c}\text { women } \\
\text { /womin/,/wumin/ }\end{array}$ & $\begin{array}{l}\text { women } \\
\text { /wimin/ }\end{array}$ & 7.1.10 \\
\hline $\begin{array}{c}\text { won't } \\
\text { /wu(:)nt/ }\end{array}$ & $\begin{array}{c}\text { won't, wont } \\
\text { /wu(:)nt/ }\end{array}$ & $\begin{array}{l}\text { won't } \\
\text { /wount/ }\end{array}$ & 7.14.14 \\
\hline $\begin{array}{l}\text { woose } \\
\text { /wuis/ }\end{array}$ & $\begin{array}{c}\text { woo'se (woose) } \\
\text { /wuis/ }\end{array}$ & $\begin{array}{l}\text { worse } \\
\text { /wo:s/ }\end{array}$ & $\begin{array}{l}7.9 .5 \mathrm{~b} \\
8.8 .5\end{array}$ \\
\hline $\begin{array}{c}\text { wool } \\
\text { /wul/,/wul// }\end{array}$ & $\begin{array}{c}\text { wool } \\
\text { /wul/, /wu:l/ }\end{array}$ & $\begin{array}{l}\text { wool } \\
\text { /wol/ }\end{array}$ & 7.6.4 \\
\hline $\begin{array}{c}\text { oonce } \\
\text { /(w)u:ns / }\end{array}$ & $\begin{array}{l}\text { woonce } \\
\text { /(w)u:ns/ }\end{array}$ & $\begin{array}{l}\text { once } \\
\text { /w } \Lambda \text { ns/ }\end{array}$ & 7.5.7 \\
\hline $\begin{array}{l}\text { oon, oone } \\
\text { /(w)u:n/ }\end{array}$ & $\begin{array}{l}\text { woone (oone) } \\
\text { /(w)u:n/ }\end{array}$ & $\begin{array}{c}\text { one } \\
\text { /wAn/ }\end{array}$ & 7.5.7 \\
\hline $\begin{array}{c}\text { wordle } \\
\text { /wə:rdəl/ }\end{array}$ & $\begin{array}{l}\text { worold } \\
\text { /wərrdəl/ }\end{array}$ & $\begin{array}{l}\text { world } \\
\text { /wə:ld/ }\end{array}$ & 8.8 .4 \\
\hline
\end{tabular}




\begin{tabular}{|c|c|c|c|}
\hline $\begin{array}{c}\text { 'ood, 'od, woud, } \\
\text { would } \\
/(\mathrm{w}) \mathrm{ud} /\end{array}$ & $\begin{array}{l}\text { would (woud) } \\
\text { /(w)ud/ }\end{array}$ & $\begin{array}{l}\text { would } \\
\text { /wud/ }\end{array}$ & 8.16 .1 \\
\hline $\begin{array}{l}\text { 'ool, 'ul, 'ull, wull, } \\
\text { will } \\
\text { /(w)ul/, /wil/ }\end{array}$ & $\begin{array}{l}\text { wull ('ull), will } \\
\text { /(w)ul/, /wil/ }\end{array}$ & $\begin{array}{l}\text { will } \\
\text { /wil/ }\end{array}$ & 8.16 .1 \\
\hline $\begin{array}{c}\text { ye (attached to } \\
\text { antecedent) } \\
\text { /i:/ } \\
\text { can ye, tell ye, var ye }\end{array}$ & $\begin{array}{c}\text { ye (attached to } \\
\text { antecedent) } \\
\text { /i: } / \\
\text { can ye, tell ye, vor } \\
\text { ye }\end{array}$ & $\begin{array}{c}\text { ye } \\
/ \mathrm{ji}(:) /\end{array}$ & 8.18 \\
\hline $\begin{array}{c}\text { year } \\
\text { /jior/,/jarr/ }\end{array}$ & $\begin{array}{c}\text { year } \\
\text { /jior/,/jə:r/ }\end{array}$ & $\begin{array}{l}\text { year } \\
\text { /jı/ }\end{array}$ & $\begin{array}{c}7.19 .3 \\
8.8 .1\end{array}$ \\
\hline $\begin{array}{c}\text { yaller, yoller } \\
\text { /jalər/ }\end{array}$ & $\begin{array}{l}\text { yollow (yollor, } \\
\text { yellow) } \\
\text { /jalər/ }\end{array}$ & $\begin{array}{l}\text { yellow } \\
\text { /jeləu/ }\end{array}$ & $\begin{array}{c}7.4 \\
7.14 .8 \\
8.8 .2\end{array}$ \\
\hline $\begin{array}{l}\text { yander } \\
\text { /jandər/ }\end{array}$ & $\begin{array}{l}\text { yonder } \\
\text { /jandər/ }\end{array}$ & $\begin{array}{l}\text { yonder } \\
\text { /jpndə/ }\end{array}$ & $\begin{array}{c}7.4 \\
8.8 .1\end{array}$ \\
\hline $\begin{array}{c}\text { ya (unstressed) } \\
/ \mathrm{j} ə /\end{array}$ & $\begin{array}{c}\text { you (unstressed) } \\
/ \mathrm{jo} /\end{array}$ & $\begin{array}{l}\text { you } \\
\text { /ju:/ }\end{array}$ & 7.15 .5 \\
\hline $\begin{array}{l}\text { your, yer, yar } \\
\text { /ju(:)ər/,/jor/ }\end{array}$ & $\begin{array}{c}\text { your } \\
/ \text { ju(:)ər/,/jər/ }\end{array}$ & $\begin{array}{c}\text { your } \\
/ \text { jo:/, /juə/,/jə/ }\end{array}$ & $\begin{array}{c}7.24 .2 \\
8.8 .1\end{array}$ \\
\hline $\begin{array}{c}\text { z (initial) } \\
\text { /z/ } \\
\text { zack, zaid, zee, zell, } \\
\text { zing, zit, zong, zoo, } \\
\text { zummer, zun }\end{array}$ & $\begin{array}{c}\text { z (initial) } \\
\text { /z/ } \\
\text { zack, zaid, zee, zell, } \\
\text { zing, zit, zong, zoo, } \\
\text { zummer, zun }\end{array}$ & $\begin{array}{c}\text { s (initial) } \\
\text { /s/ } \\
\text { sack, said, see, sell, } \\
\text { sing, sit, song, so, } \\
\text { summer, sun }\end{array}$ & 8.9 .1 \\
\hline $\begin{array}{c}\text { zuf, zelf } \\
\text { /zuf/ }\end{array}$ & $\begin{array}{c}\text { zelf (zuf) } \\
/ \mathrm{z} \wedge \mathrm{f} /\end{array}$ & $\begin{array}{l}\text { self } \\
\text { /self/ }\end{array}$ & 7.5.2 \\
\hline $\begin{array}{c}\text { zome'hat, zummat } \\
\text { /zımət/ }\end{array}$ & $\begin{array}{c}\text { zome'hat } \\
\text { (zome'at) } \\
\text { /zımət/ }\end{array}$ & $\begin{array}{l}\text { somewhat } \\
/ \mathrm{s} \Lambda \mathrm{m}(\mathrm{h}) \mathrm{wbt} /\end{array}$ & $\begin{array}{l}8.16 .2 \\
8.17 .2\end{array}$ \\
\hline
\end{tabular}




\begin{tabular}{|c|c|c|c|}
\hline $\begin{array}{c}\text { zoo ('and so, } \\
\text { therefore') } \\
\text { /zui/ }\end{array}$ & $\begin{array}{c}\text { zoo ('and so, } \\
\text { therefore') } \\
\text { /zui/ }\end{array}$ & $\begin{array}{c}\text { so } \\
\text { /səu/ }\end{array}$ \\
\hline $\begin{array}{c}\text { zot } \\
\text { zat/ }\end{array}$ & $\begin{array}{c}\text { zot } \\
\text { /zat/ }\end{array}$ & 7.14 .6 \\
\hline
\end{tabular}

\section{A note on the text}

The text of the poems follows that of 1879. Minor mechanical errors are silently corrected (unpaired quotation marks, apostrophes omitted where spaces have been left for them, full stops used where commas are evidently intended, etc.); more substantial emendations are recorded in the Textual Notes. Marginal glosses are supplied in italics for words that may cause temporary hesitation; where the same word occurs within a few lines of an earlier gloss, the gloss is not repeated. Double quotation marks are used for direct speech, for quotations, and for titles of poems and journal articles; single quotation marks are reserved for definitions and translations.

The phonemic transcripts on the pages facing the poems are based on the findings recorded in WBPG. They show the target pronunciation that is aimed at (though doubtless not always achieved) in the accompanying audio recordings. In numerous instances alternative pronunciations would be equally acceptable: most such alternatives are listed in the table of Common Alternatives on p. xvii.

\section{"Zummer stream": a line-by-line phonemic analysis}

References in parentheses are to line numbers in the poem; those in square brackets are to sections and subsections in WBPG and to the summary of those sections in the Appendix to this volume. No comment is made on words that have the same pronunciation as in RP. Dialect pronunciations are normally pointed out only on their first occurrence in the poem.

Title Zummer stream

z^mər stri:m 
Zummer-. (i) " $S$ before a vowel often but not universally becomes in Dorset its smooth kinsletter ₹, making sand, zand; sap, zeap; send, zend; set, zet; ...” (1844 Dissertation, §36; [8.9.1]). Barnes consistently spells words or word-stems with $;-$ when the initial sound is voiced, as in zummer here, zides (7), zun (10), beride (24), etc., in contrast to those in which the /s/ remains voiceless, as in stream (title), still and sträj (4), sceäly (7), etc. (ii) The $r$ is sounded in Barnes's dialect, though silent in RP [8.8.1]. This applies to all words in which Barnes retains the $r$ in spelling where it would be silent in RP, whether at the end of a word, as in zummer here, year (2), over (6), etc., or before a consonant, as in warm (2), -dartèn (8), buttervlees (12), etc., or when followed only by mute $e$, as in there (5), gleäre (7), mwore (18), etc. In such cases the $e$ is often omitted from the spelling, as in wer $(12,15$, etc.). When the $r$ is not sounded in the dialect (as in birth, hearth, horse, etc.), Barnes omits it from the spelling [8.8.5].

1 AH! then the grassy-meäded Mä̈

\section{a: ðعn ðə gra:simiədıd mæI}

Ah, grassy. (i) Long $a$ in the dialect, as in both these words, passèn (2), -dartèn (8), etc. is generally /a:/, as in Australian car park, rather than /a/ as in current RP [7.7.1], but a different vowel in some phonetic environments (cf. path in line 11). (ii) The vowel of the unstressed $y$ ending in grassy, sceäly (7), giddy (12), etc., is not / $\mathrm{I} /$ as in old-fashioned RP, but /i/ [7.1.2].

meäded. Words spelled with $e a$ in StE and pronounced /ii/ in RP may in Barnes's dialect have either the same spelling and pronunciation, as in stream (title and throughout), gleam (2), leaves (6), etc., or the diphthong /ir/ spelled eä in both the broad and the modified forms of the dialect, as in meäd here, leän, leäve (verb), etc. [7.10.8]. But the distinction is not always maintained: cf. mead-grass with no diaeresis (29).

Majy. Words spelled with ai or ay in StE and pronounced/eI/ in RP are normally spelled $a \ddot{i}$ or $a \ddot{y}$ in the modified form of the dialect, like Mäj here, sträj (4), pläj (6), maïd (16), etc. (sometimes $\ddot{a} i$ or $\ddot{a} y$ ), replacing the $\hat{a} i$ and $\hat{a} y$ spellings of the broad form. The pronunciation in Barnes's dialect 
is /æI/ as in Australian G'day [7.11.6]. (For day, say, and other words spelled with ay in Barnes's poems as opposed to ay see WBPG 7.11.7.)

\section{Did warm the passèn year, an' gleam dıd wa:rm ðə pa:sən jiər ən gli:m}

warm. The vowel sound in words spelled with ar in StE representing /o:(r)/ in RP (e.g. warm, swarm, toward), is /arr/ in Barnes's dialect; hence the rhyme sound in storm/ warm ("Don't Ceäre", 2/ 4) is not /orm/ as in RP but /a:rm/ [7.22.2]. See also or (14).

passèn. (i) For the stressed vowel see $A h$ and grassy in line 1. (ii) In both the broad and the modified forms of the dialect Barnes uses the spelling -in for the unstressed -ing ending on present participles and verbal nouns, as in a-runnèn (5) and a-slidèn (9), though the accent on the $e$ is sometimes omitted. The pronunciation, as for other words ending in unstressed -en (past participles of strong verbs, nouns such as garden, etc.), is /on/ [7.1.5].

an'. Final /d/ is frequently lost from the consonant cluster /nd/ [8.2.2], as shown by its omission from and here and in lines 7, 9, and 17 . This allows words ending in -nd in StE to rhyme with words ending in either $n$ or $n d$; hence groun' with final $d$ lost rhymes with down in the first stanza of "Fall time" but round rhymes with -brown'd (with obligatory final $d$ in the past participle) in the second.

year. Usually /jior/, much as in StE, but with a higher starting point for the diphthong and the final $r$ always sounded; sometimes /jarr/ [7.19.3].

3 Upon the yellow-grounded stream, әppn ðə jalərgrə:un(d)Id stri:m

yellow. (i) The usual spelling in the modified form of the dialect is yollow, replacing yaller or yoller in the broad form. The vowel of the stressed syllable is /a/, intermediate between /a/ and / $/$ / [7.4]. (ii) The 
unstressed second syllable in disyllabes ending in ow, like yellow here, shallow (8), window (21), etc. is generally weakened to /or/ or / / / [7.14.8].

grounded. (i) The diphthong of the first syllable, pronunced /av/ in RP, as also in out- (10), brow (15), now (18), sound (22), etc. is in Barnes's dialect /oru/, similar to that in RP go, blow, boe, etc. [7.18.1]. (ii) the /d/ in ground is optional (see $a n^{\prime}$ in line 2), perhaps more likely to be sounded here than not because of the inflexional ending that follows.

4 That still by beech-tree sheädes do strä̈.

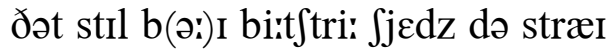

by. Either /bi/ (unstressed) or /bəil/ (stressed) [7.16.9]. For the diphthong of the stressed form see light in line 5 .

sheädes. The spelling in the modified form of the dialect for the diphthong in the sequence spelled $\mathrm{C}+a+\mathrm{C}+e$ and pronounced / $\mathrm{eI} / \mathrm{in} \mathrm{StE}$ is $e \ddot{a}$, as in weäves (5), sceäly (7), pleäce (25), etc. replacing the broad form's $i a$. The pronunciation in Barnes's dialect is / $\mathrm{j} \varepsilon /$ [7.11.1]. The disadvantage of the decision to replace $i a$ with $e \ddot{a}$ is the potential confusion of this diphthong with the /iə/ of words such as lead and lean, spelled with eä in both the broad and the modified forms of the dialect and pronounced /i:/ in RP (like meäded in line 1).

do. When used as an auxiliary, as here in the normal form of the present tense in the dialect, do is normally the unstressed /də/ [7.15.5]; when stressed, on the other hand, it is /du:/ as in RP. In 1844 Barnes consistently uses the spelling $d a$ for the unstressed auxiliary and $d o$ elsewhere, but in the modified form of the dialect the da spellings are gradually phased out until they are entirely replaced by do (see WBCP ii, Appendix 3).

5 The light o' weäves, a-runnèn there, ðə lə:It ə wjevz ər^nən ðعər 
light. The usual pronunciation in Barnes's dialect of the diphthong pronounced / aI/ in current RP, as in by when stressed (4), zides (7), -slidèn (9), time (10), etc. is/a:I/ [7.16.1].

$o^{\prime} . \quad / \mathrm{v} /$ in of is commonly lost before a consonant, yielding the pronunciation /a/ [8.3.2].

there. Where, there, and their are usually spelled wher and ther in 1844, suggesting pronunciation with / or/, particularly when the word is unstressed; when stressed, however (as in the rhyme with gleäre in line 7), the pronunciation after the initial consonant sound is / عər/ [7.20.3].

6 Did plaÿ on leaves up over head, did plæı pn liivz $\Lambda$ p o:vər hed

over. The complete consistency of the spelling auver in 1844 shows that the preferred pronunciation in the dialect was / ovvr/ [7.14.10].

7 An' vishes sceäly zides did gleäre, ən VIfIZ skjeli zə:Idz did gljeər

vishes. Initial / $\mathrm{f} /$ is voiced in the dialect in most native English words or word-stems [8.3.1]. Barnes uses $v$ to show this voicing, as in vishes for fishes' here, -vlees (12), -vled (20), vrom (21), etc. His spelling shows, however, that the initial /f/ is not normally voiced in words adopted from French, such as feäce (27), and that there are some native English words, such as flight (12), in which it is rarely or never voiced.

gleäre. The word ('glare') belongs with mare, share, fair, pair, etc., normally spelled with -iare or -iair in 1844 and -eäre or -eäir in the modified form of the dialect. The diphthong is pronounced as in RP / $\mathrm{\varepsilon a/}$ but with an introductory $i$-glide, creating the triphthong $/ \mathrm{j} \varepsilon a /$, followed by $/ \mathrm{r} /$ (see Zummer in the title), hence /jeər/[7.20.2].

8 A-dartèn on the shallow bed, əda:rtən pn ðə Jalər bed 
shallow. (i) Stressed short $a$ in Barnes's dialect, as in the first syllable here and in man (16), stand (23), etc. is /a/ as opposed to old-fashioned RP

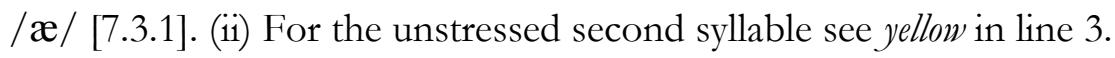

9 An' like the stream a-slidèn on, ən lik ðə stri:m əslə:Idən pn

like. Both spelling and rhyme in 1844 show that climb, strike, and like (as an adverb or in the past tense) have a short $i, / \mathrm{I} /$. As an infinitive, however, like appears to have the usual diphthong / a:I/ [7.16.5].

10 My zun-out-measur'd time's agone.

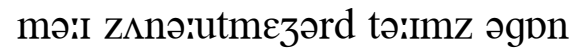

11 There by the path, in grass knee-high,

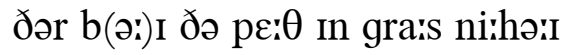

path. Many words that have the vowel /a:/ in RP have / $\varepsilon$ : in Barnes's dialect, including path and father, laugh, half, after, aunt, last, etc. A variety of different spellings is used to indicate the pronunciation in the broad form of the dialect; most are repelled as in StE in the modified form [7.7.4].

12 Wer buttervlees in giddy flight, wər bムtərvli:z In gidi flə:It

vlees. (i) The vowel is probably to be explained by the long-standing confusion in English between between the verbs fly and flee and the nouns fly and flea [7.16.6]. (ii) For the voiced initial consonant see vishes in line 7.

13 All white above the deäisies white,

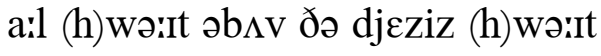

white. The initial consonant sound in words with initial $w h$ may be either aspirated /hw/, as in careful RP, or unaspirated /w/ [8.5.3]. 
deäisies. As in StE, where the diphthong in the stressed syllable of daisy (/eI/) is the same as that in shade, the diphthong of the stressed syllable in deäisies (/je/) is the same as that in sheädes (4).

14 Or blue below the deep blue sky. ar blu: bilo: ðə di:p blu: skə:I

Or. Words spelled with or in StE representing /o:/ or / or / in RP, such as or here, corm and storm elsewhere, etc. are consistently spelled with ar in 1844, indicating the pronunciation /arr/ (cf. warm in line 2). When the syllable is unstressed, however (as frequently with for, or, nor), the pronunciation is reduced (as here) to /ar/ or /or/ [7.22.1-3].

below. (i) The first syllable is as in RP. (ii) Since the second syllable is stressed, its vowel is not reduced to $/ \mathrm{\partial}(\mathrm{r}) /$ as in yellow (3) and shallow (8); but that vowel, which has become the diphthong /ov/ in RP was in some words in Barnes's dialect the pure vowel /o:/, as here and in glowèn and glow $(15,17)$, etc., and in others the diphthong / uo/, spelled wo in the modified form of the dialect, as in cwold, hwome, woak, etc. [7.14, 7.14.1-3, 7.14.14].

15 Then glowèn warm wer ev'ry brow, ðદn glo:ən wa:rm wər عvri brə:u

16 O' maïd, or man, in zummer het,

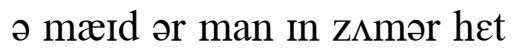

bet. In both the broad and the modified forms of the dialect beat is spelled bet and rhymed with words ending in /et/; the vowel is thus clearly not the /i:/ of StE but / $\varepsilon /[7.10 .10]$.

17 An' warm did glow the cheäks I met ən wa:rm did glo: ðə t fiəks ə:I met 
cheäks. The vowel in words spelled with ee in StE is normally pronounced /i:/ as in RP (but cf. meet in line 18). The eä spelling in cheek (indicating /iə/) suggests that the dialect form is derived from the West Saxon ceace (as might be expected in the southwest), whereas the $\mathrm{StE}$ form is from Anglian cèce. [7.10.8, 7.10.13].

18 That time, noo mwore to meet em now. ðat tə:Im nu: muər tə mi(:)t əm nə:u

noo. In both the broad and the modified forms of the dialect Barnes maintains a distinction between no (the opposite of yes), rhymed only with words ending in /o: / and always spelled no, and noo ('not any'), always so spelled and evidently pronounced /nu:/ [7.14.6].

mwore. The pronunciation in Barnes's dialect of the vowel $+r$ combination in most words with a stressed syllable spelled or $+C$, ore, oar, oor, or our that has the sound / o:/ in RP (/orr/ when followed by a vowel) is / uər/ [7.23, 7.23.1]. See also avore (28).

meet. Like keep, seem, sweet, and week, the vowel in meet may be either /i:/ as in $\mathrm{RP}$ or $/ \mathrm{I} /$, as shown in the broad form of the dialect by both spelling and rhyme. The transcription /i(:)/ allows for both possibilities [7.10.11].

$\mathrm{em}$. Loss of initial / $/$ in them and reduction of the vowel to $/ \mathrm{\partial} / \mathrm{as}$ here is common in colloquial English in all dialects as well as StE.

19 As brooks, a-slidèn on their bed, az bruks əslə:Idən pn ðər bed

20 My season-measur'd time's a-vled. mə:I si:zənmezərd tə:Imz əvled

21 Vrom yonder window, in the thatch, vrəm jandər windər in ðə ðat 
yonder. Yond (in beyond and yonder) belongs with a group of words in which the stressed vowel is sometimes spelled $o$, sometimes $a$. Since these words are rhymed sometimes on the sound $/ \mathrm{p} /$, sometimes $/ \mathrm{a} /$, the logical conclusion is that their stressed vowel is $/ \mathrm{a} /$, intermediate between these two sounds [7.4].

thatch. StE voiceless th is often voiced in SW dialects, as in thatch, thin, thistle and a number of other words. In 1844 Barnes shows this voicing by italicizing the th and in 1847 by replacing it with $\delta$; but in the modified form of the dialect-as in StE-there is nothing to indicate when th will be voiced and when it will not [8.13.1].

22 Did sound the maidens' merry words, did sə:un(d) ðə mæIdənz meri wə:rdz

23 As I did stand, by zingèn birds, əz ə:I did $\operatorname{stan}(d)$ b(ə:)I ZIngən bə:rdz

24 Bezide the elem-sheäded hatch.

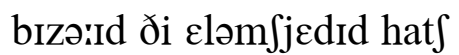

elem. "The liquids $l m$ at the end of a word are sometimes parted by a vowel, as in elem, elm; auverwhelem, overwhelm; helem, helm" (1844 Diss., \$32); accordingly elm is always disyllabic in Barnes's poems whereas in elmy, where $l m$ is not in final position, there is no epenthetic vowel separating the consonant cluster [8.6].

25 'Tis good to come back to the pleäce, tIz gud tə kım bak tə ðə pljes

26 Back to the time, to goo noo mwore; bak tə ðə tə:Im tə gu: nu: muər 
goo. Go and ago, no (in the sense 'not any'), so (in the sense 'and so, therefore'), sloe, and toe are almost invariably spelled with oo or ooe in both the broad and the modified forms of the dialect, and are rhymed with words ending in the sound /u:/, such as blue, shoe, two, etc. [7.14.6]. The pronunciation of goo is evidently/gu:/, though rare exceptions, such as the rhyme rwose/ nose/ goes in "The shy man" (41-3), show /go:/ as a possible variant.

27 'Tis good to meet the younger feäce tız gud tə mi(:)t ðə jıygər fjes

28 A-mentèn others here avore. əmentən $\Lambda$ ðrz hiər əvuər

avore. (i) Barnes's usage shows a marked preference for avore over bevore, the former outnumbering the latter in his poems in a ratio of nearly five to one. (ii) For the pronunciation of -ore see mwore (18). (iii) For the voicing of the StE $f$ (in both words) see vishes (7).

29 As streams do glide by green mead-grass, az stri:mz də glə:Id b(ə:)I gri:n miədgra:s

30 My zummer-brighten'd years do pass. mə:I zımərbrə:Itənd jiərz də pa:s 


\section{THIRD-COLLECTION POEMS}

WITH

\section{PHONEMIC TRANSCRIPTS}


O! MEÄRY, when the zun went down,

Woone night in Spring, wi' vi'ry rim,

Behind thik nap wi' woody crown,

fiery

that billock.

An' left your smilèn feäce so dim;

Your little sister there, inside,

Wi' bellows on her little knee,

Did blow the vier, a-glearèn wide

Drough window-peänes, that I could zee,-

fire

through

As you did stan' wi' me, avore

The house, a-peärten,-woone smile mwore.

The chatt'rèn birds, a-risèn high,

An' zinkèn low, did swiftly vlee

fly

Vrom shrinkèn moss, a-growèn dry,

Upon the leänèn apple tree.

An' there the dog, a-whippèn wide

His heäiry tail, an' comèn near,

Did fondly lay ageän your zide

His coal-black nose an' russet ear:

To win what I'd a-won avore,

Vrom your gaÿ feäce, his woone smile mwore.

An' while your mother bustled sprack,

briskly

A-gettèn supper out in hall,

An' cast her sheäde, a-whiv'rèn black

shadow, quivering

Avore the vier, upon the wall;

Your brother come, wi' easy peäce,

In drough the slammèn geäte, along

through

The path, wi' healthy-bloomèn feäce,

A-whis'lèn shrill his last new zong;

An' when he come avore the door,

He met vrom you his woone smile mwore. 
(w)u:n smə:il muər

o: mjeəri (h)wعn ðə zın went də:un

(w)u:n nə:It in sprin wi və:ıวri rim

bihə:In(d) ðık nap wi wudi krə:un

ən left jər smə:ilən fjes sə dim

jər litəl sistər ðعər Insə:Id

wi bilız on (h)or litəl ni:

did blo: ðə və:ıər əgljerən wə:Id

dru: windərpjenz ðət ə:I kud zi:

az ju: did stan wi mi: əvuər

ðə hə:us əpjairtən (w)uin smə:il muər

ðə t fatrən bə:rdz ərə:Izən hə:I

on zinkən lo: did swif(t)li vli:

vrəm frinkən mps əgro:ən drə:I

əppn ðә liənən apəl tri:

ən ðعər ðə dog ə(h)wipən wə:Id

(h)Iz hjeəri tæil ən kımən niər

did fon(d)li le: əgjen jər zə:Id

(h)Iz ko:lblak no:z on r $\Lambda$ sət iər

tə win (h)wDt ə:Id əw⿳n әvuər

vrəm ju(:)ər gæi fjes (h)IZ (w)uin smə:Il muər

ən (h)wə:ıl jər m^ðər bısəld sprak

əgetən s $\Lambda$ pər ə:ut in ha:l

ən kaist (h)ər fjed ə(h)wivrən blak

əvuər ðə və:ıər əppn ðə wa:l

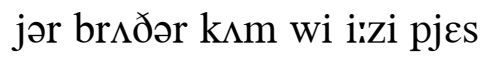

In dru: ðə slamən gjet əlpn

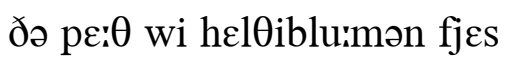

ə(h)wislən fil (h)Iz le:st nju: zDy

ən (h)wen hi: kım əvuər ðə duər

hi: met vrəm ju: (h)Iz (w)uin smə:Il muər 
Now you that wer the daughter there,

Be mother on a husband's vloor, An' mid ye meet wi' less o' ceäre

Than what your hearty mother bore;

An' if abroad I have to rue

The bitter tongue, or wrongvul deed,

Mid I come hwome to sheäre wi' you

share

What's needvul free o' pinchèn need:

An' vind that you ha' still in store,

My evenèn meal, an' woone smile mwore. 
nə:u ju: ðət wər ðə de:tər ðعər

bi: $\mathrm{m} \Lambda$ ðə pn ə h^zbən(d)z vluər ən mId i: mi(:)t wi les ə kjeər

ðən (h)wpt jər ha:rti $\mathrm{m} \Lambda$ ðr buər ən If əbro:d əit hav to ru:

ðə bitər tıy ar royvul didd

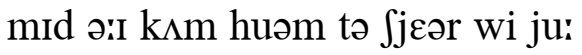

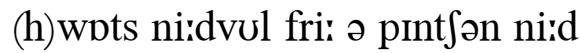
ən və:In(d) ðət ju: ha stıl in stuər mə:I i:vmən mi:l ən (w)u:n smə:Il muər 
THE ECHO

ABOUT the tow'r an' churchyard wall,

Out nearly overright our door,

A tongue ov wind did always call

Whatever we did call avore.

The vaïce did mock our neämes, our cheers,

opposite

Our merry laughs, our hands' loud claps, An' mother's call "Come, come, my dears"

Or "Do as I do bid, bad chaps"

—my dears;

—bad chaps.

An' when o' Zundays on the green,

In frocks an' cwoats as gaÿ as new,

We walk'd wi' shoes a-meäde to sheen

So black an' bright's a vull-ripe slooe

shine

sloe

We then did hear the tongue ov air

A-mockèn mother's vaïce so thin,

"Come, now the bell do goo vor praÿ'r"

"Tis time to goo to church; come in"

—vor praÿr,

- come in.

The night when little Anne, that died,

Begun to zickèn, back in Maÿ,

An' she, at dusk ov evenèn-tide,

Wer out wi' others at their plaÿ,

Within the churchyard that do keep

Her little bed, the vaïce o' thin

Dark air, mock'd mother's call "To sleep"

一to sleep;

"'Tis bed time now, my love, come in"

- come in. 
ði عko:

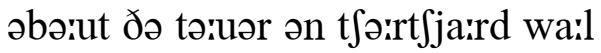

ə:ut niərli s:vərə:It ə:uər duər

ə t $\Lambda$ y $\partial \mathrm{v}$ win(d) did a:lwe:z ka:l

(h)wptevər wi: did kail əvuər

ðə væIs did mpk ə'uər njemz ə:uər t tjiərz

ə:uər meri le:fs ə:uər han(d)z lə:ud klaps

ən m^ðərz ka:l kım kım mə:I diərz

mə:I diərz

ar du: əz ə:I də bid bad t faps

bad t taps

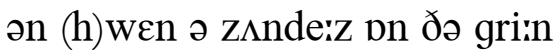

In froks ən kuəts əz gæi əz nju:

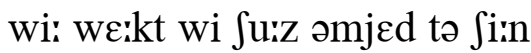

sə blak ən brə:Its ə vulrə:Ip slu:

wi: ðعn did hiər ðə t $\Lambda$ y əv æIr

əmpkən m $\Lambda$ ðərz væIs sə ðIn

kım nə:u ðə bel də gu: vər præIr

vər præIr

tIz tə:Im to gu: to t $\int \partial$ :rt $\int \mathrm{k} \wedge \mathrm{m}$ in

$\mathrm{k} \wedge \mathrm{m}$ in

ðə nə:It (h)wعn litəl an ðət də:Id

big $n$ tə zikən bak in mæI

ən $\int \mathrm{ii}$ ət $\mathrm{d} \Lambda \mathrm{sk}$ əv i:vməntə:Id

wər ə:ut wi $\Lambda$ ðrz ət ðər plæI

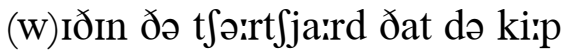

(h)ər litəl bed ðə væIs ə ðIn

da:rk ærr mpkt m^ðərz ka:l tə sli:p

to sli:p

tIz bed tə:Im nə:u mə:I $1 \Lambda \mathrm{v} \mathrm{k} \wedge \mathrm{m}$ in

kım in 
An' when our Jeäne come out so smart

A-married, an' we help'd her in

To Henry's newly-païnted cart,

The while the wheels begun to spin, An' her gaÿ nods, vor all she smil'd,

Did sheäke a tear-drop vrom each eye, The vaïce mock'd mother's call, "Dear child"

mimicked

— dear child;

"God bless ye evermwore; good bye"

-good bye. 
ən (h)wen əruər djjen kım ərut sə smarrt əmarid ən wi: helpt (h)ər in to henriz nju:lipæintıd ka:rt

ðə (h)wə:Il ðə (h)wi:lz big^n tə spin ən (h)ər gæı nodz vər a:l Si: smə:Ild

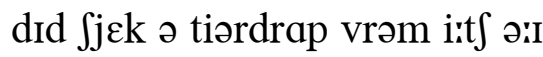
ðə væIs mpkt m^ðərz ka:l diər tfəiıl(d)

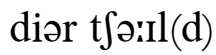

gpd bles i: عvərmuər gud bə:I

gud bə:I 
No, I'm a man, I'm vull a man,

You beät my manhood, if you can.

You'll be a man if you can teäke

All steätes that household life do meäke.

The love-toss'd child, a-croodlèn loud, cooing

The bwoy a-screamèn wild in plaÿ, The tall grown youth a-steppèn proud,

The father staïd, the house's staÿ. mature

No; I can boast if others can,

I'm vull a man.

A young-cheäk'd mother's tears mid vall, may

When woone a-lost, not half man-tall, one

Vrom little hand, a-called vrom plaÿ,

Do leäve noo tool, but drop a taÿ, toy

An' die avore he's father-free

To sheäpe his life by his own plan;

An' vull an angel he shall be,

But here on e'th not vull a man,

earth

No; I could boast if others can,

I'm vull a man.

I woonce, a child, wer father-fed, once

An' I've a-vound my childern bread;

My eärm, a sister's trusty crook, arm Is now a faïthvul wife's own hook; An' I've a-gone where vo'k did zend, folk

An' gone upon my own free mind, An' of en at my own wits' end,

A-led o' God while I wer blind.

No; I could boast if others can

I'm vull a man. 
vul ə man

no: ว:Im ə man ə:Im vul ə man ju: biət mə:I manhud If jə kan jəl bi: ə man If ju: kən tjek a:l stjets ðət hə:ushuəld lə:If də mjek ðə luvtnst tfə:Il(d) əkrudlən lə:ud ðə bwə:I əskri:mən wə:Ild in plæI ðə ta:lgrə:un ju: $\theta$ əstepən prə:ud ðə fє:ðər stæId ðə hə:usIz stæI no: ə:I kən bo:st If $\Lambda$ ðərz kan ə:Im vul ə man

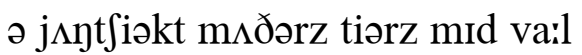

(h)wen (w)u:n əlpst npt he:f manta:l vrəm litəl han(d) əka:ld vrəm plæı də liəv nu: tu:l bət drap ə tæI ən də:I əvuər hi:z fє:ðərfri:

to $\int j \varepsilon p(h) I z$ lə:If b(ə:)I (h)IZ o:n plan ən vul ən andzəl hi: $\int \partial l$ bi:

bət hiər pn $\varepsilon \theta$ npt vul ə man no: ə:I kud bo:st If $\Lambda$ ðərz kan ə:Im vul ə man

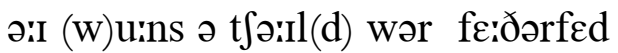
ən ว:IV əvə:un(d) məiI tfildərn bred mə:I ja:rm ə sistərz tr $\Lambda$ sti kruk Iz nə:u ə fæi $\theta v u l$ wə:Ifs o:n huk ən ə:Iv əgpn (h)wər vo:k did zen(d) ən gpn əppn mə:I o:n fri: mə:In(d) ən pfən ət mə:I o:n wits $\varepsilon n(d)$ əled ə gpd (h)wə:Il ə:I wər blə:In(d) no: ə:I kud bo:st If $\Lambda$ ðərz kan ə:Im vul ə man 
An' still, ov all my tweil ha' won,

My lovèn maïd an' merry son,

daughter

Though each in turn's a jaÿ an' ceäre,

joy

'Ve a-had, an' still shall have, their sheäre;

share

An' then, if God should bless their lives,

Why I mid zend vrom son to son

may

My life, right on drough men an' wives,

As long, good now, as time do run.

No; I could boast if others can,

I'm vull a man. 
ən strl əv a:l mə:I twə:Il hə wAn

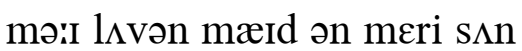
ðо: i:t $\int$ in tə:rnz ə dzæi ən kjeər v əhad ən stil $\int a l$ hav ðər $\int j \varepsilon ə r$ ən ðعn If gpd Jud bles ðər lə:IVz

(h)Wə:I ə:I mId zen(d) vrəm s $\Lambda \mathrm{n}$ tə $\mathrm{s} \Lambda \mathrm{n}$ mə:I lə:If rə:It pn dru: men ən wə:IVZ

əz lpy gud nə:u əz tə:Im də r $\wedge$ n no: ə:I kud bo:st If $\Lambda$ ðərz kan ə:Im vul ə man 


\section{NAÏGHBOUR PLAŸMEÄTES}

O JAŸ betide the dear wold mill, joy, old

My naïghbour plaÿmeätes' happy hwome, Wi' rollèn wheel, an' leäpèn foam,

Below the overhangèn hill,

Where, wide an' slow,

The stream did flow,

An' flags did grow, an' lightly vlee

Below the grey-leav'd withy tree,

fly

willow

While clack, clack, clack, vrom hour to hour,

Wi' whirlèn stwone, an' streamèn flour,

Did goo the mill by cloty Stour.

An' there in geämes by evenèn skies,

When Meäry zot her down to rest,

The broach upon her pankèn breast,

Did quickly vall an' lightly rise,

While swans did zwim

In steätely trim.

An' swifts did skim the water, bright

Wi' whirlèn froth, in western light;

An' clack, clack, clack, that happy hour,

Wi' whirlèn stwone, an' streamèn flour,

Did goo the mill by cloty Stour.

Now mortery jeints, in streaks o' white, joints

Along the geärden wall do show

In Maÿ, an' cherry boughs do blow,

bloom

Wi' bloomèn tutties, snowy white,

Where rollèn round,

Wi' rumblèn sound,

The wheel woonce drown'd the vaïce so dear

once

To me. I faïn would goo to hear 
næibər plæımjets

o: dzæi bitə:Id ðə diər (w)uəld mil mə:I næibər plæImjets hapi huəm wi ro:lən (h)will ən liəpən fo:m

bilo: ðə ১:vərhayən hil

(h)wər wə:Id ən slo:

ðə stri:m did flo:

ən flagz did gro: ən lə:tlli vli:

bılo: ðə gre:liivd wıði tri:

(h)wəril klak klak klak vrəm əruər tu ə:uər wi (h)wərr(d)lən stuən ən stri:mən flə:uər did gu: ðə mIl b(ə:)I klo:ti stə:uər

ən ðعər In gjemz b(ə:)I i:vmən skə:Iz

(h)wen mjeəri zat (h)ər də'un tə rest ðə bro:t

did kwıkli va:l ən lə:Itli rə:Iz

(h)wəril swonz did zwim In stjetli trim

ən $\operatorname{swif}(t) s$ did skim ðə wə:tər brə:it wi (h)wər(d)lən fro $\theta$ in westərn lə:it on klak klak klak ðat hapi ə:uər wi (h)wər(d)lən stuən ən stri:mən flə:uər did gu: ðə mil b(ə:)I klo:ti stə:uər

nə:u ma:rtri dzə:Ints in striəks ə (h)wə:It əlpy ðə gja:rdən wa:l də Jo: In mæi ən t $\int \varepsilon r i$ bə:uz də blo: wi blu:mən t $\Lambda$ tiz sno:i (h)wə:It

(h)wər ro:lən rə:und wi rımblən sə:und ðə (h)wi:l (w)u:ns drə:und ðə væIs sə diər to mi: ə:I fæIn wud gu: to hiər 
The clack, clack, clack, vor woone short hour,

Wi' whirlèn stwone, an' streamèn flour,

Bezide the mill on cloty Stour.

But should I vind a-heavèn now

Her breast wi' aïr o' thik dear pleäce?

that

Or zee dark locks by such a brow,

Or het o' plaÿ on such a feäce?

beat

No! She's now staid,

grown up

An' where she plaÿ'd,

There's noo such maid that now ha' took

The pleäce that she ha' long vorsook,

Though clack, clack, clack, vrom hour to hour,

Wi' whirlèn stwone an' streamèn flour,

Do goo the mill by cloty Stour.

An' still the pulley rwope do heist

hoist

The wheat vrom red-wheeled waggon beds.

An' ho'ses there wi' lwoads of grist,

Do stand an' toss their heavy heads;

But on the vloor,

Or at the door,

Do show noo mwore the kindly feäce

Her father show'd about the pleäce,

As clack, clack, clack, vrom hour to hour,

Wi' whirlèn stwone, an' streamèn flour,

Did goo his mill by cloty Stour. 
ðə klak klak klak vər (w)u:n Sa:rt ə:uər wi (h)wərr(d)lən stuən ən stri:mən flə:uər bIzə:Id ðə mil pn klo:ti stə:uər

bət $\int u d$ əII və:In(d) əhi:vən nə:u

(h)ər brest wi æir ə ðık diər pljes

ar zi: darrk lpks b(ə:)I sit $\int$ ə brə:u

ar het ə plæi pn sit $\int$ ə fjes

no: $\int i: z$ nə:u stæid

ən (h)wər fi: plæId

ðərz nu: sit $\int$ mæid ðət nə:u hə tuk

ðə pljes ðət $\int i$ ii hə lpy varsuk

ðo: klak klak klak vrəm ə:uər tə ə:uər

wi (h)wərr(d)lən stuən ən stri:mən fləruər

də gu: ðə mil b(ə:)I klo:ti stə:uər

ən stıl ðə puli ruəp də hə:Ist

ðə (h)wiit vrəm red(h)wild wagən bedz

ən hpsiz ðər wi luədz əv grə:Ist

də $\operatorname{stan}(d)$ ən tos ðər hevi hedz

bət pn ðə vluər

ar at ðə duər

də So: nu: muər ðə kə:In(d)li fjes

(h)ər fe:ðər fo:d əbə:ut ðə pljes

əz klak klak klak vrəm ə:uər to ə:uər

wi (h)wərr(d)lən stuən ən stri:mən flə:uər

did gu: (h)Iz mil b(ə:)I klo:ti stəuər 
THE LARK

As I, below the mornèn sky,

Wer out a workèn in the lew

shelter

O' black-stemm'd thorns, a-springèn high,

Avore the worold-boundèn blue,

A-reäkèn, under woak tree boughs,

oak

The orts a-left behin' by cows,

left-overs of hay

Above the grey-grow'd thistle rings,

An' deäisy-buds, the lark, in flight,

Did zing a-loft, wi' flappèn wings,

Tho' mwore in heärèn than in zight;

The while my bwoys, in plaÿvul me'th,

mirth

Did run till they wer out o' breath.

Then woone, wi' han'-besheäded eyes, one

A-stoppèn still, as he did run,

Look'd up to zee the lark arise

A-zingèn to the high-gone zun;

The while his brother look'd below

Vor what the groun' mid have to show.

Zoo woone did watch above his head

The bird his hands could never teäke;

An' woone, below, where he did tread,

Vound out the nest within the breäke;

But, aggs be only woonce a-vound,

eggs, once

An' uncaught larks ageän mid sound. 
ðə la:rk

az ə:I bilo: ðə ma:rnən skə:I

wər ə:ut ə wərrkən In ðə lu:

ə blakstemd ða:rnz əsprinən hə:I

əvuər ðə wə:rdəlbə:undən blu:

ərjekən $\Lambda$ ndər (w)uək tri: bəruz

ði a:rts əleft bihə:In b(ə:)I kə:uz

әb么v ðə gre:grə:ud ðısəl rinz

ən djezib $\Lambda \mathrm{dz}$ ðə la:rk in flə:it

did zin əlpft wi flapon winz

ðo: muər in hiərən ðən in zə:It

ðə (h)wə:Il mə:ı bwə:Iz in plæIvul me $\theta$

did rAn til ðe: wər əiut ə bre $\theta$

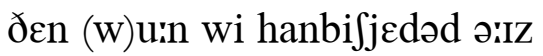

əstppən strl əz hi: did r $\wedge n$

lukt $\Lambda p$ tə zi: ðə la:rk ərə:Iz

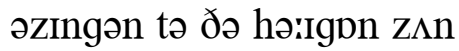

ðə (h)wə:Il (h)Iz br^ðər lukt bilo:

vər (h)wpt ðə grə:un mid hav tə fo:

zu: (w)u:n did wpt $\partial \mathrm{b} \Lambda \mathrm{v}$ (h)Iz hed

ðə bə:rd (h) Iz han(d)z kud nevər tjek

on (w)u:n bilo: (h)wər hi: did tred

və:un(d) ə:ut ðə nest (w)Iðın ðə brjek

bət agz bi: o:nli (w)u:ns əvə:un(d)

ən $\Lambda$ nkə:t lairks əgjen mid sə:un(d) 
A HAPPY day, a happy year,

A zummer Zunday, dazzlèn clear,

I went athirt vrom Lea to Noke,

across

To goo to church wi' Fanny's vo'k:

folk

The sky o' blue did only show

A cloud or two, so white as snow,

An' aïr did swaÿ, wi' softest strokes,

The eltrot roun' the dark-bough'd woaks.

cow-parsley, oaks

O day o' rest when bells do toll!

O day a-blest to ev'ry soul!

How sweet the zwells o' Zunday bells.

An' on the cowslip-knap at Creech, billock.

Below the grove o' steätely beech,

I heärd two tow'rs a-cheemèn clear, chiming

Vrom woone I went, to woone drew near, one

As they did call, by flow'ry ground,

The bright-shod veet vrom housen round,

A-drownèn wi' their holy call,

The goocoo an' the water-vall.

cuckoo

Die off, O bells o' my dear pleäce,

Ring out, $\mathrm{O}$ bells avore my feäce,

Vull sweet your zwells, $\mathrm{O}$ ding-dong bells.

Ah! then vor things that time did bring

My kinsvo'k, Lea had bells to ring;

kinsfolk

An' then, ageän, vor what bevell

My wife's, why Noke church had a bell;

But soon wi' hopevul lives a-bound

In woone, we had woone tower's sound,

Vor our high jaÿs all vive bells rung,

Our losses had woone iron tongue. 


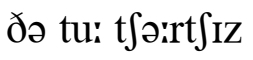

ə hapi de: ə hapi jiər

ə zımər zınde: dazlən kliər

ว:I went əðə:rt vrəm li: to no:k

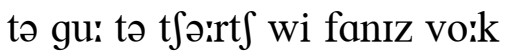

ðə skə:I ə blu: did o:nli Jo:

ə klə'ud ər tu: sə (h)wə:It əz sno:

ən æIr did swæI wi spftıst stro:ks

ði عltrpt rə:un ðə da:rkbə:ud (w)uəks

o: de: ə rest (h)wen belz də to:l

o: de: əblest tu evri so:l

hə:u swi(:)t ðə zwelz ə zムnde: belz

ən pn ðə kə:uslip nap ət kritt

bilo: ðə gro:v a stjetli bi:t

ə:I hiərd tu: tə'uərz ət ji:mən kliər

vrəm (w)u:n əiI went to (w)u:n dru: niər

əz ðe: did ka:l b(ə:) I flə:uri grə:un(d)

ðə brə:It fpd vi:t vrəm hə:uzən rə:un(d)

ədrə:unən wi ðər ho:li ka:l

ðə guku: ən ðə wə:tərva:l

də:I pf o: belz ə mə:I diər pljes

rin ə:ut o: belz əvuər mə:I fjes

vul swi(:)t jər zwelz o: dindpy belz

a: ðعn vər ðıңz ðət tə:Im did brin mə: kinzvo:k li: had belz to rin ən ðعn əgjen vər (h)wpt bivel

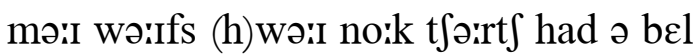
bət su:n wi ho:pvol lə:Ivz əbə:un(d) In (w)u:n wi: had (w)u:n tə:uərz sə:un(d) vər ə'uər hə:I dzæız a:l və:Iv belz rıy ə:uər losiz had (w)uin ə:Iərn t $\Lambda$ y 
Oh! ring all round, an' never mwoän

So deep an' slow woone bell alwone,

Vor sweet your swells o' vive clear bells. 
o: rin a:l rə:un(d) ən nevər muən

sə di:p ən slo: (w)uin bel əluən

vər swi(:)t jər swelz ə və:Iv kliər belz 
WHEN sycamore leaves wer a-spreadèn,

Green-ruddy, in hedges,

Bezide the red doust o' the ridges,

dust

A-dried at Woak Hill;

I packed up my goods all a-sheenèn

shining

Wi' long years o' handlèn,

On dousty red wheels ov a waggon,

To ride at Woak Hill.

The brown thatchen ruf o' the dwellèn,

roof

I then wer a-leävèn,

Had shelter'd the sleek head o' Meäry,

My bride at Woak Hill.

But now vor zome years, her light voot-vall

'S a-lost vrom the vloorèn.

floors

Too soon vor my jaÿ an' my childern,

joy

She died at Woak Hill.

But still I do think that, in soul,

She do hover about us;

To ho vor her motherless childern, care

Her pride at Woak Hill.

Zoo-lest she should tell me hereafter

so

I stole off 'ithout her,

An' left her, uncall'd at house-riddèn,

moving house

To bide at Woak Hill_-

I call'd her so fondly, wi' lippèns

lip-movements

All soundless to others, 
(w)uək hil

(h)wen sIkəmuər liivz wər əspredən gri:nr $\Lambda$ di in hedzIz

bIzə:Id ðə rعd də:ust ə ðə $\mathrm{r} \Lambda \mathrm{d} 3 \mathrm{IZ}$ ədrə:Id ət (w)uək hil

ə:I pakt $\Lambda$ p mə:I gudz a:l ə९i:nən wi lpy jiərz ə handlən pn dərusti red (h)wi:lz əv ə wagən tə rə:Id ət (w)uək hil ðə brə:un ðatfən $\mathrm{r} \Lambda \mathrm{f}$ ə ðə dwعlən əiI ðعn wər əliəvən

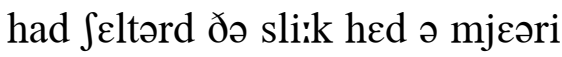
mə:I brə:Id ət (w)uək hil

bət nə:u vər zムm jiərz (h)ər lə:it vutva:l

z əlpst vrəm ðə vluərən

tu: su:n vər mə:I dzæi ən mə:I t $t$ Ildərn

fi: də:Id ət (w)uək hil

bət strl ə:I də ðınk ðat in so:l

fi: də hpvər əbərut əs

tə ho: vər (h)ər m^ðərlis tfildərn

(h)ər prəitd ət (w)uək hil

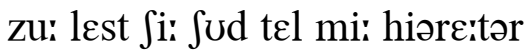
ə:I sto:l pf Iðə:ut hər

ən left hər $\Lambda$ ka:ld ət hə:usridən to bə:Id ət (w)uək hil

ə:I ka:ld (h)ər sə fon(d)li wi lipənz a:l sə:un(d)les tu $\Lambda$ ðərz 
An' took her wi' airr-reachèn hand,

To my zide at Woak Hill.

On the road I did look round, a-talkèn

To light at my shoulder,

An' then led her in at the door-way,

Miles wide vrom Woak Hill.

An' that's why vo'k thought, vor a season,

My mind wer a-wandrèn

Wi' sorrow, when I wer so sorely

A-tried at Woak Hill.

But no; that my Meäry mid never

Behold herzelf slighted,

I wanted to think that I guided

My guide vrom Woak Hill. 


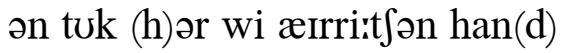

to mə:I zə:Id ət (w)uək hil

pn ðə ro:d ə:I did luk rə:un(d) ətc:kən

to lə:It ət mə:I fo:ldər

ən ðعn led (h)ər in ət ðə duərwə:I

mə:Ilz wə:Id vrəm (w)uək hil

ən ðats (h)wə:I vo:k ðo:t vər ə si:zən

mə:I mə:In(d) wər əwbndrən

wi sarə(r) (h)wen ə:I wər sə suərli

ətrə:Id ət (w)uək hil

bət no: ðət mə:I mjeəri mid nevər

bihuəld hərzıf slə:itid

ə:I wontıd tə ðınk ðət ə:I gə:IdId

mə:I gə:Id vrəm (w)uək hil 


\section{THE HEDGER}

UPON the hedge theäse bank did bear,

this

Wi' lwonesome thought untwold in words,

I woonce did work, wi' noo sound there

once

But my own strokes, an' chirpèn birds;

As down the west the zun went wan,

An' days brought on our Zunday's rest,

When sounds o' cheemèn bells did vill

chiming

The aï, an' hook an' axe wer still.

Along the wold town-path vo'k went,

old, folk

An' met unknown, or friend wi' friend,

The maild her busy mother zent,

The mother wi' noo maïd to zend;

An' in the light the gleäzier's glass,

As he did pass, wer dazzlèn bright,

Or woone went by wi' down-cast head,

one

A-wrapp'd in blackness vor the dead.

An' then the bank, wi' risèn back,

That's now a-most a-troddèn down,

Bore thorns wi' rind o' sheeny black,

bark, shiny

An' meäple stems o' ribby brown;

An' in the lewth o' theäse tree heads,

Wer primrwose beds a-sprung in blooth,

shelter, these

bloom

An' here a geäte, a-slammèn to,

Did let the slow-wheel'd plough roll drough.

wagon, through

Ov all that then went by, but vew

Be now a-left behine', to beät

The mornèn flow'rs or evenèn dew,

Or slam the woakèn vive-bar'd geäte;

made of oak 
ðə hedzər

əppn ðə hed3 ðiəs bayk did beər

wi luənsəm ðo:t $\Lambda$ ntuəld in wə:rdz ว:I (w)u:ns did wərrk wi nu: sərun(d) ðعər

bət mə:I o:n stro:ks ən tfə:rpən bə:rdz

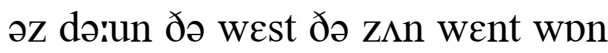
ən de:z bro:t pn ə:uər zınde:z rest (h)wen sərun(d)z ə t fi:mən belz did vil ði ærr ən huk ən aks wər strl

əlpy ðə (w)uəld tə:unpe: $\theta$ vo:k went on met $\Lambda$ nno:n ar fren(d) wi fren(d) ðə mæId (h)ər bızi m^ðər zent

ðə m^ðər wi nu: mæId tə zen(d) ən In ðə lə:It ðə gljєzjərz glais əz hi: did pais wər dazlən brə:it ar (w)uin went b(ə:)I wi də:unkaist hed ərapt in blaknəs vər ðə ded

ən ðعn ðə bayk wi rə:Izən bak ðəts nə:u a:məst ətrpdən də:un buər ða:rnz wi rə:In(d) ə Siini blak ən mjepəl stemz ə ribi brə:un ən In ðə lu: $\theta$ ə ðiəz tri: hedz wər primruəz bedz əspr $\wedge$ y in blu: $\theta$ ən hiər ə gjet əslamən tu: did let ðə slə:u(h)wi:ld plə:u ro:l dru:

əv a:l ðət ðعn went bə:I bət vju:

bi: nə:u əleft bihə:In to biət ðə ma:rnən flə:uərz ər iivmən dju: ar slam ðə (w)uəkən və:Ivba:rd gjet 
But woone, my wife, so litty-stepp'd,

light-

That have a-kept my path o' life,

Wi' her vew errands on the road,

Where woonce she bore her mother's lwoad.

once 
bət (w)u:n mə:I wə:If sə litistept

ðət hav əkept mə:I pe: $\theta$ ə lə:If

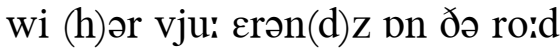

(h)wər (w)uins fi: buər (h)ər m^ðərz luəd 
MY love is the maïd ov all maïdens,

Though all mid be comely, may
jasmine

Her skin's lik' the jessamy blossom

A-spread in the Spring.

Her smile is so sweet as a beäby's

Young smile on his mother,

Her eyes be as bright as the dew drop

A-shed in the Spring.

O grey-leafy pinks o' the geärden,

Now bear her sweet blossoms;

Now deck wi' a rwose-bud, O briar,

Her head in the Spring.

O light-rollèn wind blow me hither,

The vaïce ov her talkèn,

Or bring vrom her veet the light doust,

dust

She do tread in the Spring.

O zun, meäke the gil'cups all glitter,

buttercups

In goold all around her;

An' meäke o' the deäisys' white flowers

A bed in the Spring.

O whissle gaÿ birds, up bezide her,

In drong-waÿ, an' woodlands,

narrow lane

$\mathrm{O}$ zing, swingèn lark, now the clouds,

Be a-vled in the Spring.

flown 
In ðə sprin

mə:I $1 \Lambda \mathrm{v}$ Iz ðə mæId əv a:l mæIdənz

ðo: a:l mid bi: kımli

(h)ər skınz lik ðə dzєsəmi blpsəm

əspred In ðə sprin

(h)ər smə:Il Iz sə swi(:)t əz ə bjદbiz

j $\Lambda$ y smə:Il pn (h)Iz m $\Lambda$ ðər

(h)ər ə:Iz bi: əz brə:It əz ðə dju: drap ə⿻टd In ðə sprin

o: gre:li:fi pınks ə ðə gja:rdən nə:u beər (h)ər swi(:)t blpsəmz nə:u dek wi ə ruəzb $\Lambda$ d o: brər:ər (h)ər hed In ðə sprin

o: lə:Itro:lən win(d) blo: mi: hıðər ðə væIS əv (h)ər tع:kən ar brin vrəm (h)ər vi:t ðə lə:it də:ust fi: də tred In ðə sprin

o: zın mjek ðə gilkıps a:l glitər In guild ail ərə:un(d) hər ən mjek ə ðə djeziz (h)wə:It flə:uərz ə bed In ðə sprin

o: (h)wisəl gæi bə:rdz $\Lambda$ p bizə:Id hər In droywær on (w)udlən(d)z o: zIy swinən larrk nə:u ðə klə:udz bi: əvled In ðə sprin 
An' who, you mid ax, be my praïses

A-meäkèn so much o',

An' oh! 'tis the maïd I'm a-hopèn

To wed in the Spring. 
ən hu: jə mid a:ks bi: mə:I præızəz əmjekən sə $\mathrm{m} \Lambda \mathrm{t} \int$ ə

ən o: tIz ðə mæId ə:Im əho:pən

to wed in ðə sprin 
THE FLOOD IN SPRING

LAST night below the elem in the lew

shelter

Bright the sky did gleam

On water blue, while air did softly blow

On the flowèn stream,

An' there wer gil'cups' buds untwold,

buttercups'

An' deäisies that begun to vwold

fold

Their low-stemm'd blossoms vrom my zight

Ageän the night, an' evenèn's cwold.

But, oh! so cwold below the darksome cloud

Soon the night-wind roar'd,

Wi' rainy storms that zent the zwollèn streams

Over ev'ry vword.

ford

The while the drippèn tow'r did tell

The hour, wi' storm-be-smother'd bell,

An' over ev'ry flower's bud

Roll'd on the flood, 'ithin the dell.

But when the zun arose, an' lik' a rwose

Shone the mornèn sky;

An' roun' the woak, the wind a-blowèn weak,

oak

Softly whiver'd by.

trembled

Though drown'd wer still the deäisy bed

Below the flood, its feäce instead

O' flow'ry grown', below our shoes

Show'd feäirest views o' skies o'er head.

An' zoo to try if all our faïth is true

so

Jaÿ mid end in tears,

joy may

An' hope, woonce feäir, mid saddèn into fear,

once

Here in e'thly years.

eartbly 
ðə flıd In sprin

le:st nə:It bilo: ði عləm in ðə lu: brə:It ðə skə:I did gli:m

pn wo:tər blu: (h)wə:Il æIr did spf(t)li blo:

pn ðə flo:ən stri:m

ən ðعər wər gilkıps b $\Lambda \mathrm{dz}$ nntuəld

ən djeziz ðət big

ðər lə:ustemd blpsəmz vrəm mə:I zə:It

əgjen ðə nə:It ən i:vmənz kuəld

bət o: sə kuəld bilo: ðə da:rksəm klərud

su:n ðə nə:Itwin(d) ruərd

wi ræıni sta:rmz ðət zent ðə zwo:lən stri:mz

o:vər عvri vuərd

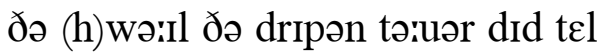

ði ə:uər wi sta:rmbi:sm^ðərd bel

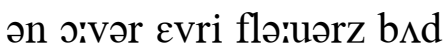

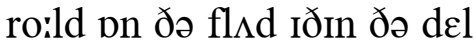

bət (h)wعn ðə z^n əro:z ən lik ə ruəz

Jpn ðə ma:rnən skə:I

ən rə:un ðə (w)uək ðə win(d) əblo:ən wi:k

$\operatorname{spf}(\mathrm{t})$ li (h)wivərd bə:I

ðo: drə:und wər stıl ðə djezi bed

bilo: ðə flıd its fjes Insted

ə flə:uri grə:un bilo: ə:uər Ju:z

fo:d fjeərəst vju:z ə skə:Iz orrhed

ən zu: to trə:I If a:l ə:uər fæi $\theta$ Iz tru:

dzæi mid $\varepsilon n(d)$ In tiorz

ən ho:p (w)u:ns fjeər mid sadən intə fiər

hiər In $\varepsilon \theta$ li jiərz 
But He that tried our soul do know

To meäke us good amends, an' show

Instead o' things a-took awaÿ,

Some higher jaÿ that He'll bestow.

joy 
bət hi: ðət trə:Id ə:uər so:l də no:

tə mjek əs gud əmen(d)z ən So:

Insted ə ðInz ətuk əwə:I

sım hə:ıər dzæı ðət hi:l bisto: 


\section{COMÈN HWOME}

As clouds did ride wi' heästy flight,

An' woods did swäy upon the height,

An' bleädes o' grass did sheäke, below

The hedge-row bremble's swingèn bow,

arc

I come back hwome where winds did zwell,

In whirls along the woody gleädes,

On primrwose beds, in windy sheädes,

To Burnley's dark-tree'd dell.

There hills do screen the timber's bough,

The trees do screen the leäze's brow,

meadow's

The timber-sheäded leäze do bear

A beäten path that we do wear.

The path do stripe the leäze's zide,

To willows at the river's edge,

Where hufflèn winds did sheäke the zedge,

gusty

An’ sparklèn weäves did glide.

An' where the river, bend by bend,

Do draïn our meäd, an' mark its end,

The hangèn leäze do teäke our cows,

sloping

An' trees do sheäde em wi' their boughs,

An' I the quicker beät the road,

To zee a-comèn into view,

Still greener vrom the sky-line's blue,

Wold Burnley our abode.

old 
kımən huəm

az klə:udz did rə:Id wi hjesti flə:It ən wudz did swæi əppn ðə hə:It ən bljedz ə gra:s did fjek bilo: ðə hedzro: brembəlz swinən bo: ə:I kım bak huəm (h)wər win(d)z did zwel In (h)wərrlz əlpy ðə wudi gljedz pn primruəz bedz in windi $\int j \varepsilon d z$ to bə:rnliz da:rktri:d del

ðعər hilz də skri:n ðə timbərz bə:u ðə triiz də skri:n ðə liəzız brə:u

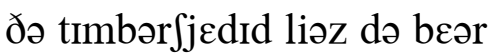
ə biətən pe: $\theta$ ðət wi: də weər

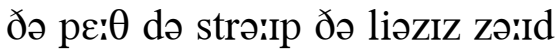
to wilərz ət ðə rivərz $\varepsilon d 3$

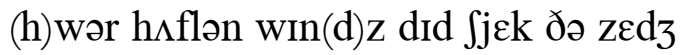
ən spa:rklən wjevz did glə:Id

ən (h)wər ðə rIvər ben(d) b(ə:)I ben(d) də dræIn ə:uər miəd ən ma:rk its $\varepsilon n(d)$ ðə hayən liəz də tjek ə;uər kə;uz ən tri:z də $\int j \varepsilon d$ əm wi ðər bə:uz ən ə:I ðə kwıkər biət ðə ro:d tə zi: əkımən intə vju:

stıl gri:nər vrəm ðə skə:Ilə:Inz blu: (w)uəld bə:rnli ə:uər əbo:d 
“THE zunny copse ha' birds to zing, The leäze ha' cows to low, meadow The elem trees ha' rooks on wing, The meäds a brook to flow, But I can walk noo mwore, to pass The drashel out abrode, To wear a path in theäse year's grass threshold, (to go) outside

Or tread the wheelworn road,"

Cried Grammer, "then adieu, $\mathrm{O}$ runnèn brooks, An' vleèn rooks,

I can't come out to you.

If 'tis God's will, why then 'tis well, That I should bide 'ithin a wall."

An' then the childern, wild wi' fun,

An' loud wi' jaÿvul sounds,

Sprung in an' cried, "We had a run,

A-plaÿèn heäre an' hounds;

But oh! the cowslips where we stopt

In Maÿcreech, on the knap!" billock.

An' vrom their little han's each dropt

Some cowslips in her lap.

Cried Grammer, "Only zee!

I can't teäke strolls, An' little souls

Would bring the vields to me.

Since 'tis God's will, an' mus' be well

That I should bide 'ithin a wall." 
gramər əkrıpəld

ðə zıni kpps ha bə:rdz tə zın

ðə liəz hə kə:uz to lo:

ði عləm tri:z ha ruks pn win

ðə miədz ə bruk to flo:

bət ə:I kən we:k nu: muər to pa:s

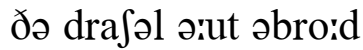

to weər ə pe: $\theta$ in ðiəs jiərz grais

ar tred ðə (h)willwa:rn ro:d

krə:Id gramər ðen adju:

o: rınən bruks

on vli:ən ruks

ə:I ke:nt kım ə:ut tə ju:

If tIz gpdz wil (h)wə:I ðعn tIz wel

ðat ə:I sud bə:Id ıðın ə wa:l

ən ðعn ðə tfrldərn wə:ıl(d) wi f $\Lambda$ n

ən lə:ud wi dzæıvul sə:un(d)z

$\operatorname{spr} \wedge$ y In ən krə:Id wi: had ə r $\wedge n$

əplæıən hjeər ən hə:un(d)z

bət o: ðə kə:uslips (h)wər wi: stppt

In mærkritt pn ðə nap

ən vrəm ðər litəl hanz i:t drapt

səm kə;uslips in (h)ər lap

krə:Id gramər o:nli zi:

ә:I ke:nt tjek stro:lz

ən litəl so:lz

wud brin ðə vi:l(d)z tə mi:

sins tIz godz wil on mıs bi: wel

ðat ə:I Jud bə:Id ıðın ə wa:l 
“Oh! there be prison walls to hold

The han's o' lawless crimes,

An' there be walls arear'd vor wold

raised, old

An' zick in tryèn times;

But oh! though low mid slant my ruf,

may, roof

Though hard my lot mid be,

Though dry mid come my daily lwoaf,

Mid mercy leäve me free!”

Cried Grammer, "Or adieu

To jaÿ; O grounds,

joy, fields

An' birds' gaÿ sounds

If I mus' gi'e up you,

give

Although 'tis well, in God's good will,

That I should bide 'ithin a wall."

“Oh! then," we answer'd, "never fret,

If we shall be a-blest,

We'll work vull hard drough het an' wet

through beat

To keep your heart at rest:

The woaken chair's vor you to vill,

oak

For you shall glow the coal,

An' when the win' do whissle sh'ill

We'll screen it vrom your poll."

shrilly

head

Cried Grammer, "God is true.

I can't but feel

He smote to heal

My wounded heart in you;

An' zoo 'tis well, if 'tis His will,

so

That I be here 'ithin a wall." 
o: ðər bi: prizən wailz tə huəld ðə han(d)z ə le:lis krə:Imz ən ठər bi: wa:lz əreərd var (w)uəld ən zik in trə:Iən tə:Imz bət o: ðo: lo: mid sle:nt mə:I $\mathrm{r} \Lambda \mathrm{f}$ ðo: ha:rd mə:i lpt mid bi: ðo: drə:I mid kım mə:I de:li luəf mid mərrsi liəv mi: fri: krə:Id gramər ar adju: tə dzæi o: grə:un(d)z ən bə:rdz gæi sə:un $(d) z$ If ə:I $m \Lambda s$ gi: $\Lambda p$ ju: a:lðo: tız wel in gpdz gud wil ðat ə:I sud bə:Id ıðın ə wa:l

o: ðعn wi: ع:nsərd nevər fret If wi: Səl bi: əblest wiil wərrk vol haird dru: het on wet to ki(:)p jor ha:rt ot rest ðə (w)uəkən t $\int \varepsilon ə r z$ var ju: tə vil var ju: Jəl glo: ðə ko:l ən (h)wen ðə win(d) də (h)wisəl fil wi:l skri:n it vrəm jər po:l krəild gramər gpd iz tru: ə:I ke:nt bət vi:l hi: smo:t to hi:l mə:I wu:ndid ha:rt in ju: ən zu: tız wel If tız (h)IZ wil ðat ə:I bi: hiər Iðın ə wa:l 
A HAPPY day at Whitsuntide,

As soon's the zun begun to vall,

We all stroll'd up the steep hill-zide

To Meldon, girt an' small;

great

Out where the castle wall stood high

A-mwoldrèn to the zunny sky.

mouldering

An' there wi' Jenny took a stroll

Her youngest sister, Poll, so gaÿ,

Bezide John Hind, ah! merry soul,

An' mid her wedlock faÿ;

An' at our zides did plaÿ an' run

My little maïd an' smaller son.

may, prosper

daughter

Above the beäten mwold upsprung earth

The driven doust, a-spreadèn light, dust

An' on the new-leav'd thorn, a-hung,

Wer wool a-quiv'rèn white;

An' corn, a sheenèn bright, did bow,

On slopèn Meldon's zunny brow.

shining, bend

There, down the rufless wall did glow roofless

The zun upon the grassy vloor,

An' weakly-wandrèn winds did blow,

Unhinder'd by a door;

An' smokeless now avore the zun

Did stan' the ivy-girded tun.

chimney

My bwoy did watch the daws' bright wings

jackdaw's

A-flappèn vrom their ivy bow'rs;

My wife did watch my maïd's light springs,

danghter's

Out here an' there vor flow'rs; 
ðə ka:səl ru:Inz

ə hapi de: ət (h)witsəntə:Id

əz suinz ðə z^n big $\Lambda$ tə va:l

wi: a:l stro:ld $\Lambda$ p ðə sti:p hilzə:Id

tə meldən gə:rt ən sma:l

ə:ut (h)wər ðə ka:səl wa:l stud hə:I

əmuəldrən tə ðə z^ni skə:I

ən ðعər wi dzєni tuk ə stro:l

(h)ər j jџgIst sistər ppl sə gæi

bizə:Id dzan hə:In(d) a: meri so:l

ən mId (h)ər wedlpk fæi

ən at ə:uər zə:Idz did plæı ən r $\wedge$ n

mə:I litəl mæid ən sma:lər s $\Lambda$ n

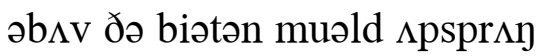

ðə drivən də:ust əspredən lə:ıt

ən pn ðə nju:li:vd ða:rn əh^y

wər wul əkwIVrən (h)wəit

ən ka:rn ə९i:nən brə:It did bə:u

pn slo:pən meldənz zıni brə:u

ðعər də:un ðə rıflıs wa:l did glo:

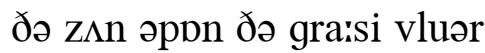

ən wikkliwpndrən win (d)z did blo:

$\Lambda$ nhindərd b(ə:) I ə duər

ən smo:klis nə:u əvuər ðə z^n

did stan ðə ə:Ivigə:rdıd t $\Lambda$ n

mə:I bwə:I did wpt

əflapən vrəm ðər ə:Ivi bə:uərz

mə:I wə:If did wpt $\int$ mə:I mæIdz lə:It sprinz

ə:ut hiər ən ðعər vər flə:uərz 
And John did zee noo tow'rs, the pleäce Vor him had only Polly's feäce.

An' there, of all that pried about

The walls, I overlook'd em best, An' what o' that? Why, I meäde out

Noo mwore than all the rest:

That there wer woonce the nest of zome once

That wer a-gone avore we come,

When woonce above the tun the smoke chimney-top

Did wreathy blue among the trees, An' down below, the livèn vo'k, folk

Did tweil as brisk as bees; toil

Or zit wi' weary knees, the while

The sky wer lightless to their tweil. 
ən(d) dzan did zi: nu: tə:uərz ðə pljes vər hIm had o:nli ppliz fjes

ən ðعər əv a:l ðət prə:Id əbə:ut ðә wa:lz ə:I ə:vərlukt əm best ən (h)wpt ə ðat (h)wə:I ə:I mjed ə:ut nu: muər ðən a:l ðə rest

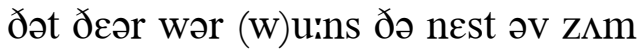
ðət wər əgpn əvuər wi: kım

(h)wen (w)u:ns əb $\Lambda$ v ðə tın ðə smo:k did ri:ði blu: əmpy ðə tri:z ən də:un bilo: ðə livən vo:k did twə:il əz brisk əz bi:z ər zit wi wiəri ni:z ðə (h)wə:Il ðə skə:I wər lə:Itlis tə ðər twə:Il 
ECLOGUE

JOHN, JEALOUS AT SHROTON FEÄIR

Jeäne; her Brother; John, her Sweetheart; and Racketèn Joe

\section{JEÄNE}

I'M thankvul I be out o' that

Thick crowd, an' not asquot quite flat.

squashed

That ever we should plunge in where the vo'k do drunge

folk, crowd

So tight's the cheese-wring on the veät!

vat

I've sca'ce a thing a-left in pleäce.

'Tis all a-tore vrom pin an' leäce.

My bonnet's like a wad, a-beät up to a dod, beap

An' all my heäir's about my feäce.

HER BROTHER

Here, come an' zit out here a bit, An' put yourzelf to rights.

JOHN

No, Jeäne; no, no! Now you don't show

The very wo'st o' plights.

HER BROTHER

Come, come, there's little harm adone;

Your hoops be out so roun's the zun.

\section{JOHN}

An' there's your bonnet back in sheäpe.

HER BROTHER

An' there's your pin, and there's your ceäpe. 
Eklpg

dzan dzeləs ət $\int$ pdən fjeər

dzjen (h)ər br^ðər dzan (h)ər swi(:)tha:rt ən(d) rakətən dzo:

JEÄNE

ə:Im $\theta$ aykvul ə:I bi: ə:ut ə ðat

Өrk krə:ud ən npt əskwpt kwəit flat

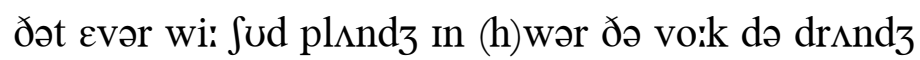

sə tə:its ðə tfiizrin pn ðə vjat

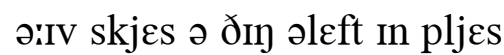

tIz a:l ətuər vrəm pin ən ljes

mə:I bpnits lik $ə$ wpd əbiət $\Lambda p$ tu $ə$ dpd

ən a:l mə:I hjeərz əbə:ut mə:I fjes

HER BROTHER

hiər kım ən zit ərut hiər ə bit

ən pst jərzıf to rə:Its

JOHN

no: dzjen no: no: nə:u jə do:nt fo:

ðə veri W $\Lambda$ st ə plə:its

HER BROTHER

$\mathrm{k} \wedge \mathrm{m} \mathrm{k} \wedge \mathrm{m}$ ðərz litəl ha:rm əd $\Lambda \mathrm{n}$

jər hu:ps bi: ə’ut sə rə:unz ðə z^n

JOHN

ən ðərz jər bpnit bak in Jjep

HER BROTHER

ən ðərz jər pın ən(d) ðərz jər kjep 
JOHN

An' there your curls do match, an' there

'S the vittiest maïd in all the feäir.

properest

JEÄNE

Now look, an' tell us who's a-spied

Vrom Sturminster, or Manston zide.

HER BROTHER

There's rantèn Joe! How he do stalk,

An' zwang his whip, an' laugh, an' talk!

swing violently

JOHN

An' how his head do wag, avore his steppèn lag.

Jist like a pigeon's in a walk!

HER BROTHER

Heigh! there, then, Joey, ben’t we proud!

JEÄNE

He can't hear you among the crowd.

HER BROTHER

Why, no, the thunder peals do drown the sound o' wheels.

His own pipe is a-pitched too loud.

What, you here too?

RACKETÈN JOE

Yes, Sir, to you.

All o' me that's a-left. 
JOHN

ən ðعər jər kərrlz də mat

z ðə vitisst mæId In a:l ðə fjeər

JEÄNE

nə:u luk ən tel əs hu:z əspə:Id

vrəm stə:rmistər ər mansən zə:Id

HER BROTHER

ðعərz re:ntən dzo: hə:u hi: də ste:k

ən zway (h)Iz (h)wip ən le:f ən te:k

JOHN

ən hə:u (h)Iz hed də wag əvuər (h)Iz stepən lag

dzIst lik ə pidzənz in ə we:k

HER BROTHER

hæi ðعər ðعn dzo:i be:nt wi: prə:ud

JEÄNE

hi: ke:nt hiər ju: əmpy ðə krə:ud

HER BROTHER

(h)wə:ı no: ðə $\theta \Lambda$ ndər pi:lz də drə:un ðə sə:un(d) ə (h)willz

(h)Iz o:n pə:Ip Iz əpitft tu: lə:ud

(h)wpt ju: hiər tu:

RACKETÈN JOE

its sə:r to ju:

a:l ə mi: ðəts əleft 
JEÄNE

A body plump's a goodish lump

Where reämes ha' such a heft.

a skeleton, weight

JOHN

Who lost his crown a-racèn?

RACKETÈN JOE

Who?

Zome silly chap abackèn you.

Well, now, an' how do vo'k treat Jeäne?

folk

JEÄNE

Why not wi' feärèns.

gifts bought at a fair

RACKETÈN JOE

What d'ye meän,

When I've a-brought ye such a bunch

O' theäse nice ginger-nuts to crunch?

these

An' here, John, here! you teäke a vew.

JOHN

No, keep em all vor Jeäne an' you!

\section{RACKETÈN JOE}

Well, Jeäne, an' when d'ye meän to come

An' call on me, then, up at hwome.

You han't a-come athirt, since I'd my voot a-hurt, across A-slippèn vrom the tree I clomb. 
JEÄNE

ə bpdi pl $\Lambda \mathrm{mp}$ s a gudis $1 \Lambda \mathrm{mp}$

(h)wər rjemz hə sit $\int$ ə heft

JOHN

hu: lost (h)Iz krə:un ərjesən

RACKETÈN JOE

hu:

z^m sili tfap əbakən ju:

wel nə:u ən hə:u də vo:k tri:t dzjen

JEÄNE

(h)wə:I not wi fjeərənz

RACKETÈN JOE

(h)wpt dji: miən

(h)wen ə:Iv əbro:t i: sit $\int$ ə b $\Lambda$ t $\int$

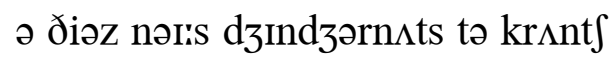

ən hiər dzan hiər ju: tjek ə vju:

JOHN

no: $k i(:) p$ əm a:l vər dzjen ən ju:

RACKETÈN JOE

wel dzjen ən (h)wen dji: miən to kım

ən ka:l pn mi: ðعn $\Lambda$ p ət huəm

jə hant əkım əðə:rt sins ə:Id mə:I vut əhə:rt

əslipən vrəm ðə tri: ə:I kl $\Lambda \mathrm{m}$ 
JEÄNE

Well, if so be that you be stout

On voot ageän, you'll vind me out.

JOHN

Aye, better chaps woont goo, not many steps vor you,

If you do hawk yourzelf about.

RACKETÈN JOE

Wull John, come too?

JOHN

No, thanks to you.

Two's company, dree's nwone.

three's

HER BROTHER

There don't be stung by his mad tongue,

'Tis nothèn else but fun.

JEÄNE

There, what d'ye think o' my new ceäpe?

JOHN

Why, think that'tis an ugly sheäpe.

JEÄNE

Then you should buy me, now theäse feäir,

this

A mwore becomèn woone to wear.

one 
JEÄNE

wel If so: bi: ðət jə bi: stə:ut

pn vot əgjen ju:l və:In(d) mi: ə:ut

JOHN

æI betər t $\int$ aps wu(:)nt gu: not meni steps vər ju:

If jə də he:k jərzıf əbə:ut

RACKETÈN JOE

wol dzan kım tu:

JOHN

no: $\theta$ ayks to ju:

tu:z kımpəni dri:z nuən

HER BROTHER

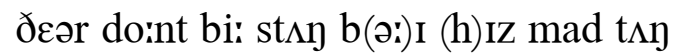

tız n $\Lambda \theta ə n$ els bət f $\Lambda \mathrm{n}$

JEÄNE

ðعər (h)wpt dji: ðınk ə mə:I nju: kjep

JOHN

(h)wə:I ðınk ðət tIz ən $\Lambda$ gli $\int j \varepsilon p$

JEÄNE

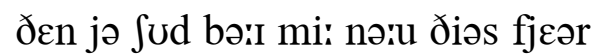

ə muər bikımən (w)u:n tə weər 


\section{JOHN}

I buy your ceäpe! No; Joe wull screäpe

Up dibs enough to buy your ceäpe.

coins

As things do look, to meäke you fine

Is long Joe's business mwore than mine.

JEÄNE

Lauk, John, the mwore that you do pout

Lord

The mwore he'll glēne.

sneer

JOHN

A yelpèn lout. 
JOHN

ə:I bə:I juər kjep no: dzo: wul skrjep

$\Lambda \mathrm{p}$ dibz in $\Lambda \mathrm{f}$ to bə:I jər kjep

az ðInz do luk to mjek ju: fə:In

Iz lpy dzo:z biznis muər ðən mə:In

JEÄNE

lə:k dzan ðə muər ðət ju: də pərut ðə muər hi:l gle:n

JOHN

ə jelpən lə:ut 
EARLY PLAŸMEÄTE

AFTER many long years had a-run,

The while I wer a-gone vrom the pleäce,

I come back to the vields, where the zun

Ov her childhood did show me her feäce.

There her father, years wolder, did stoop.

older

An' her brother, wer now a-grow'd staid, mature

An' the apple tree lower did droop.

Out in the orcha'd where we had a-plaÿd,

There wer zome things a-seemèn the seäme,

But Meäry's a-married awaÿ.

There wer two little childern a-zent,

Wi' a message to me, oh! so feäir

As the mother that they did zoo ment,

When in childhood she plaÿ'd wi' me there.

Zoo they twold me that if I would come so take after

Down to Coomb, I should zee a wold friend, so

Vor a plaÿmeäte o' mine wer at hwome,

An' would staÿ till another week's end.

At the dear pworchèd door, could I dare

To zee Meäry a-married awaÿ!

On the flower-not, now all a-trod

Stwony hard, the green grass wer a-spread,

An' the long-slighted woodbine did nod

Vrom the wall, wi' a loose-hangèn head.

An' the martin's clay nest wer a-hung

Up below the brown oves, in the dry, eaves

An' the rooks had a-rock'd broods o' young

On the elems below the Maÿ sky;

But the bud on the bed, coulden bide,

Wi' young Meäry a-married awaÿ. 
jə:rli plæımjet

ع:tər meni lon jiərz had ər $\Lambda$ n

ðə (h)wə:Il ə:I wər əgpn vrəm ðə pljes

ə:I kım bak tə ðə vi:l(d)z (h)wər ðə z^n

əv (h)ər tfəril(d)hud did fo: mi: (h)ər fjes

ðعər (h)ər fe:ðər jiərz (w)uəldər did stu:p

ən (h)ər br^ðər wər nə:u əgro:d stæıd

ən ði apəl tri: lo:ər did dru:p

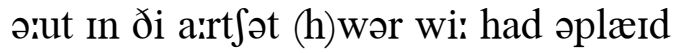

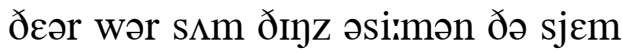

bət mjeəriz əmarid əwæI

ðər wər tu: litəl tfIldərn əzent

wi ə mesid 3 to mi: o: sə fjeər

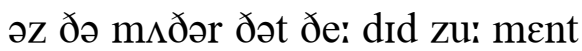

(h)wen in t fə:Il(d)hud Ji: plæId wi mi: ðعər

zu: ðe: tuəld mi: ðət If ə:I wud kım

də:un tə ku:m ə:I Sud zi: ə (w)uəld fren(d)

vər ə plæimjet ə mə:In wər at huəm

ən wud stæı tIl ən^ðər wi(:)ks عn(d)

ət ðə diər puərtfəd duər kud ə:I djeər

to zi: mjeəri əmarid əwæI

pn ðə flə:uərnpt nə:u a:l ətrpd

stuəni ha:rd ðə gri:n gra:s wər əspred

ən ðə lpyslə:itıd wudbə:In did nod

vrəm ðə wa:l wi ə lusshayən hed

ən ðə ma:rtınz kle: nest wər əh^y

$\Lambda$ p bilo: ðə brə:un o:vz In ðə drə:I

ən ðə ruks had ərokt bru:dz ə j $\Lambda$

pn ði عləmz bilo: ðə mæI skə:I

bət ðə bᄉd pn ðə bed kudən bə:Id

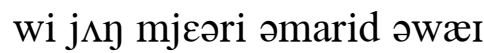


There the copse-wood, a-grow'd to a height, Wer a-vell'd, an' the primrwose in blooth, bloom Among chips on the ground a-turn'd white,

Wer a-quiv'rèn, all beäre ov his lewth.

bare, shelter

The green moss wer a-spread on the thatch,

That I left yollow reed, an' avore

The small green, there did swing a new hatch, wicket-gate

Vor to let me walk into the door.

Oh! the rook did still rock o'er the rick,

But wi' Meäry a-married awaÿ. 
ðعər ðə kppswud əgro:d tu ə hə:It

wər əveld ən ðə primruəz in blu: $\theta$

əmpy t $\int$ Ips pn ðə grə:un(d) ətə:rnd (h)wə:It

wər əkwivrən a:l bjeər əv (h)Iz lu: $\theta$

ðə gri:n mps wər əspred pn ðə ðat

ðət ə:I left jalər ri:d ən əvuər

ðə sma:l gri:n ðər did swin ə nju: hat

vər tə let mi: we:k intə ðə duər

o: ðə ruk did stıl rok orr ðə rik

bət wi mjeəri əmarid əwæI 
OH! the wood wer a-vell'd in the copse,

An' the moss-bedded primrwose did blow;

bloom
tall-trunked
shadows
through

An' the sky wer a-showèn, in drough

By the tree-stems, the deepest o' blue,

Wi' a light that did vall on an' off

The dry ground, a-strew'd over wi' scroff.

There the hedge that wer leätely so high,

Wer a-plush'd, an' along by the zide, with half-cut stems interlaced

Where the waggon ' $\mathrm{d}$ a-haul'd the wood by,

There did reach the deep wheelrouts, a-dried. wheel-ruts

An' the groun' wi' the sticks wer bespread,

Zome a-cut off alive, an' zome dead.

An' vor burnèn, well wo'th reäkèn off,

By the childern a-pickèn o' scroff.

In the tree-studded leäze, where the woak

meadow, oak

Wer a-spreadèn his head out around,

There the scrags that the wind had a-broke,

Wer a-lyèn about on the ground.

Or the childern, wi' little red hands,

Wer a-tyèn em up in their bands;

Vor noo squier or farmer turn'd off

turned away

Little childern a-pickèn o' scroff.

There wer woone bloomèn child wi' a cloak

one

On her shoulders, as green as the ground;

An' another, as gray as the woak,

Wi' a bwoy in a brown frock, a-brown'd. 
prkən ə skrof

o: ðə wud wər əveld in ðə kpps

ən ðə mpsbedid primruəz did blo:

ən vrəm ta:lsteməd triiz lifflis tops

ðər did lə:I bət slə:it $\int j \varepsilon d z$ də:un bilo:

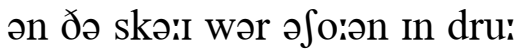

b(ә:)I ðə trisstemz ðə di:pıst ə blu:

wi ə lə:It ðət did va:l pn ən pf

ðə drə:I grə氵un(d) əstru:d ə:vər wi skrpf

ðعər ðə hedz ðət wər ljetli sə hə:I

wər əpl $\Lambda \int t$ ən əlpy b(ə:)I ðə zə:Id

(h)wər ðə wagən d əha:ld ðə wud bə:I

ðər did ritt ðə di:p (h)wi:lrə:uts ədrə:Id

ən ðə grə:un wi ðə stıks wər bispred

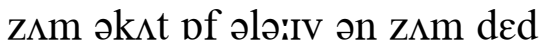

ən vər bə:rnən wel wpð rjekən of

b(ə:)I ðə t fildərn apıkən ə skrof

In ðə trisst $\Lambda$ dId liəz (h)wər ðə (w)uək

wər əspredən (h)Iz hed ərut ərə:un(d)

ðər ðə skragz ðət ðə wIn(d) had əbro:k

wər ələ:Iən əbə:ut pn ðə grə:un(d)

ar ðə t fildərn wi litəl red han(d)z

wər ətə:Iən əm $\Lambda$ p in ठər ban(d)z

vər nu: skwə:ıər ar fa:rmər tə:rnd $\mathrm{pf}$

litəl t fildərn apıkən ə skrpf

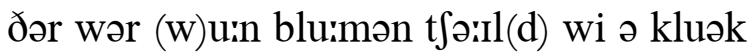

pn (h)ər fo:ldərz əz gri:n əz ðə grə:und

ən ən^ðər əz gre: əz ðə (w)uək

wi ə bwว:I In ə brə:un frok əbrə:und 
An’ woone got up, in plaÿ, vor to taït,

On a woak-limb, a-growèn out straïght.

But she soon wer a-taïted down off,

By her meätes out a-pickèn o’ scroff.

When they childern do grow to staïd vo'k,

adult folk

An' goo out in the worold, all wide

Vrom the copse, an' the zummerleäze woak,

summer-pasture

Where at last all their elders ha' died,

They wull then vind it touchèn to bring,

To their minds, the sweet springs o' their spring,

Back avore the new vo'k did turn off

The poor childern a-pickèn o’ scroff. 
ən (w)uin gpt $\Lambda$ p in plæi vər to tæit pn ə (w)uəklim əgro:ən ə:ut stræit bət $\int i$ i: suin wər ətæitıd də:un pf b(ə:)I (h)ər mjets ə:ut apıkən ə skrof

(h)wen ðe: t f Ildərn də gro: to stæId vo:k ən gu: ə:ut In ðə wərrdəl a:l wərid vrəm ðə kpps ən ðə zムmərliəz (w)uək

(h)wər at le:st a:l ðər eldərz hə də:Id ðе: wul ठعn və:In(d) it t $\Lambda$ t $\int ә n$ to brin tə ðər mə:In(d)z ðə swi(:)t sprinz ə ðər sprıy bak əvuər ðə nju: vo:k did tə:rn pf ðə pu(:)ər tfildərn apıkən ə skrpf 


\section{GOOD NIGHT}

WHILE down the meäds wound slow,

Water vor green-wheel'd mills,

Over the streams bright bow,

arc

Win' come vrom dark-back'd hills.

Birds on the win' shot along down steep

Slopes, wi' a swift-swung zweep.

Dim weän'd the red streak'd west.

Lim'-weary souls “Good-rest."

Up on the plough'd hill brow,

Still wer the zull's wheel'd beam,

Still wer the red-wheel'd plough,

Free o' the strong limb'd team,

Still wer the shop that the smith meäde ring,

Dark where the sparks did spring;

Low shot the zun's last beams.

Lim'-weary souls “Good dreams.”

Where I vrom dark bank-sheädes

Turn'd up the west hill road,

Where all the green grass bleädes

Under the zunlight glow'd,

Startled I met, as the zunbeams plaÿ'd

Light, wi' a zunsmote maid,

Come vor my day's last zight.

Zun-brighten'd maïd "Good night." 
gud nə:It

(h)wə:ıl də:un ðə miədz wə:un(d) slo:

wo:tər vər gri:n(h)wild milz

ว:vər ðə stri:mz brə:It bo:

win(d) kım vrəm darrkbakt hilz

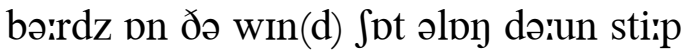

slo:ps wi ə swif(t)sw

dim wjend ðə red strikt west

limwiori so:lz gudrest

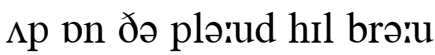

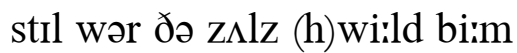

stıl wər ðə $\operatorname{red}(\mathrm{h})$ wi:ld plə:u

fri: ə ðə strpy $\lim (\mathrm{d})$ ti:m

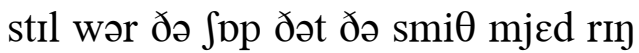

da:rk (h)wər ðə spa:rks did sprin

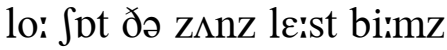

limwiori so:lz gud dri:mz

(h)wər ə:I vrəm darrk bayk jjedz

tə:rnd $\Lambda \mathrm{p}$ бə west hil ro:d

(h)wər a:l ðə gri:n gra:s bljedz

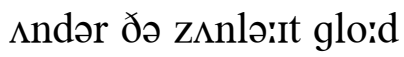

sta:rtəld ə:I met əz ðə z $\Lambda$ nbi:mz plæId

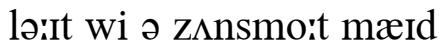

kım vər mə:I de:z le:st zə:It

zınbrə:Itənd mæid gud nə:It 
UPON the slope, the hedge did bound The vield wi' blossom-whited zide, An' charlock patches, yollow-dyed,

Did reach along the white-soil'd ground;

An' vo'k, a-comèn up vrom meäd,

Brought gil'cup meal upon the shoe;

folk
buttercup

thick dust

Wi' smeechy doust from heel to tooe,

As noon did smite, wi' burnèn light,

The road so white, to Meldonley.

An' I did tramp the zun-dried ground,

By hedge-climb'd hills, a-spread wi' flow'rs,

An' watershootèn dells, an' tow'rs,

By elem-trees a-hemm'd all round,

To zee a vew wold friends, about

old

Wold Meldon, where I still ha' zome,

That bid me speed as I come out,

wished me success

An' now ha' bid me welcome hwome,

As I did goo, while skies wer blue,

Vrom view to view, to Meldonley.

An' there wer timber'd knaps, that show'd

billocks

Cool sheädes, vor rest, on grassy ground,

An' thatch-brow'd windows, flower-bound,

Where I could wish wer my abode.

I pass'd the maild avore the spring,

An' shepherd by the thornèn tree;

An' heärd the merry dréver zing,

But met noo kith or kin to me,

Till I come down, vrom Meldon's crown

To rufs o' brown, at Meldonley.

roofs 
went huəm

əppn ðə slo:p ðə hed3 did bə:un(d)

ðə vi:l(d) wi blpsəm(h)wə:ItId zə:Id

ən t $\int a$ arlpk pat $\int \mathrm{Iz}$ jalərdə:Id

did ri:t əlpy ðə (h)wə:Itswə:Ild grə:un(d)

ən vo:k əkımən $\Lambda$ p vrəm miəd

bro:t gilkıp mi:l əppn ðə Ju:

ar went pn (h)wər ðə ro:d did liəd

wi smi:t $\int i$ dərust vrom hisl to tu:

az nu:n did smə:It wi bə:rnən lə:it

ðə ro:d sə (h)wə:It tə meldənli:

ən ə:I did tramp ðə zیndrə:Id grə:un(d) b(ə:)I hedzklimd hilz əspred wi flə:uərz ən wo:tərكutən delz ən tə:uərz b(ə:)I عləmtri:z əhemd a:l rə:un(d) to zi: ə vju: (w)uəld fren(d)z əbərut

(w)uəld meldən (h)wər ə:I strl ha z^m ðət bId mi: spi:d əz ə:I kım ərut

ən nə:u hə bid mi: welkəm huəm əz ə:I did gu: (h)wə:Il skə:Iz wər blu: vrəm vju: to vju: tə meldənli:

ən ðعər wər tımbərd naps ðət fo:d ku:l $\int j \varepsilon d z$ vər rest pn graisi grə:un(d) ən ðat5brə:ud windərz flə:uərbə:un(d) (h)wər ə:I kud wI w wər mə:I əbo:d ə:I paist ठə mæId əvuər ðə sprin

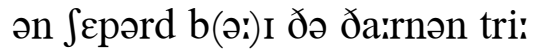
ən hiərd ðə meri dre:vər zIn bət met nu: ki $\theta$ or kin to mi: tıl ə:I kım dəiun vrəm meldənz krəiun tə $\mathrm{r} \Lambda \mathrm{fs}$ ə brə:un ət meldənli: 
THE woaken tree, so hollow now, oak

To souls ov other times wer sound, An' reach'd on ev'ry zide a bough

Above their heads, a-gather'd round, But zome light veet That here did meet

In friendship sweet, vor rest or jaÿ, joy Shall be a-miss'd another Maÿ.

My childern here, in plaÿvul pride

Did zit 'ithin his wooden walls, A-mentèn steätely vo'k inside its

O' castle towers an' lofty halls.

But now the vloor

An' mossy door

That woonce they wore would be too small once

To teäke em in, so big an' tall.

Theäse year do show, wi' snow-white cloud, this An' deäsies in a sprinkled bed, An' green-bough birds a-whislèn loud,

The looks o' zummer days a-vled;

An' grass do grow, An' men do mow,

An' all do show the wold times' feäce old

Wi' new things in the wold things' pleäce. 
ðə hplər (w)uək

ðə (w)uəkən tri: sə hplər nə:u

tə so:lz əv $\Lambda$ ðr tə:Imz wər sə:un(d)

ən ritt $\int \mathrm{d}$ pn evri zə:Id ə bə:u

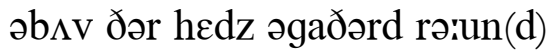

bət zムm lə:It vi:t

ðət hiər did mi:t

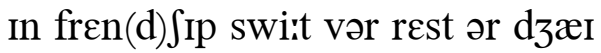

Səl bi: əmıst ən^ðər mæI

mə:I t $f$ Ildərn hiər in plæivul prə:Id

did zit Iðın (h)Iz wudən wa:lz

əmentən stjetli vo:k insə:Id

ə ka:səl tə:uərz ən lpfti ha:lz

bət nə:u ðə vluər

ən mpsi duər

ðət (w)u:ns ðe: wuər wod bi: tu: sma:l

to tjek əm In sə big ən ta:l

ðiəs jiər də fo: wi sno:(h)wə:It klə:ud

ən djeziz In ə sprinkəld bed

ən gri:nbə:u bə:rdz ə(h)wislən lə:ud

ðə luks ə zımər de:z əvled

ən gra:s də gro:

ən men də mo:

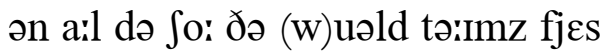

wi nju: ðınz In ðə (w)uəld ðınz pljes 


\section{CHILDERN'S CHILDERN}

OH! if my ling'rèn life should run,

Drough years a-reckoned ten by ten, through

Below the never-tirèn zun,

Till beäbes ageän be wives an' men;

An' stillest deafness should ha' bound

My ears, at last, vrom ev'ry sound;

Though still my eyes in that sweet light,

Should have the zight o' sky an' ground:

Would then my steäte

In time so leäte,

Be jaÿ or païn, be païn or jaỹ?

When Zunday then, a-weänèn dim,

As theäse that now's a-clwosèn still,

Mid lose the zun's down-zinkèn rim,

In light behind the vier-bound hill;

waning

this one, closing might

An' when the bells' last peal's a-rung,

An' I mid zee the wold an' young fire-

A-vlockèn by, but shoulden hear,

However near, a voot or tongue:

Mid zuch a zight,

In that soft light

Be jaÿ or païn, be païn or jaÿ?

If I should zee among em all,

In merry youth, a-glidèn by,

My son's bwold son, a-grown man-tall,

Or daughter's daughter, woman-high;

An' she mid smile wi' your good feäce,

Or she mid walk your comely peäce,

But seem, although a-chattèn loud,

So dumb's a cloud, in that bright pleäce: 


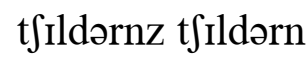

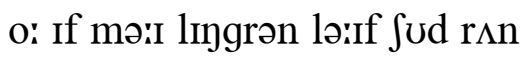

dru: jiərz ərekənd ten $b(\partial:)$ I ten

bilo: ðə nعvərtə:Irən $\mathrm{z} \Lambda \mathrm{n}$

tıl bjebz əgjen bi: wə:IVz ən men

ən strlist defnis $\int u d$ hə bə:un(d)

mə:I iərz ət le:st vrəm عvri sə'un(d)

ðo: stıl mə:I ə:Iz In ðat swi(:)t lə:It

\ud hav ðə zə:It ə skə:I ən grə:un(d)

wud ðعn mə:I stjet

In tə:Im sə ljet

bi: dzæI ər pæIn bi: pæIn ər dzæI

(h)wen zınde: ðعn əwjenən dim

əz ðiəs ðət nə:uz əkluəzən stıl

mid lu:z ðə z^nz də:unzınkən rIm

In lə:It bihə:In(d) ðə və:Irbə:un(d) hil

ən (h)wen ठə belz le:st pi:lz ər $\wedge$ y

ən ə:I mId zi: ðə (w)uəld ən j $\wedge$ y

əvlpkən bə:I bət $\int u d ə n$ hiər

həruevor niər a vut ar t $\Lambda$ y

mid zut ə zə:It

In ðat spft lə:it

bi: dzæi ər pæIn bi: pæIn or dzæI

If ə:I Jud zi: əmpy əm a:l

In meri ju: $\theta$ əglə:Idən bə:I

mə:I s $\Lambda \mathrm{nz}$ buəld s $\Lambda \mathrm{n}$ əgro:n manta:l

ar de:tərz de:tər wumənhə:I

ən fi: mid smə:Il wi ju(:)ər gud fjes

ər fi: mId we:k ju(:)ər kımli pjes

bət si(:)m a:lðo: ət Jatən lə:ud

sə d $\Lambda \mathrm{mz}$ ə klə:ud in ðat brə:It pljes 
Would youth so feäir,

A-passèn there,

Be jaÿ or païn, be païn or jaÿ?

'Tis seldom strangth or comeliness

Do leäve us long. The house do show

Men's sons wi' mwore, as they ha' less,

An' daughters brisk, vor mothers slow.

A dawn do clear the night's dim sky,

Woone star do zink, an' woone goo high,

An' livèn gifts o' youth do vall,

Vrom girt to small, but never die:

great

An' should I view,

What God mid do,

may

Wi' jaÿ or païn, wi' païn or jaÿ? 
wud jui $\theta$ sə fjeər

әpaisən ðعər

bi: dzæi ər pæIn bi: pæIn ər dzæI

tIz seldəm stray $\theta$ ər kımlines

də liəv əs lpy ðə hə‘us də Jo:

menz s $n z$ wi muər əz ðe: ha les

ən de:tərz brisk vər $\mathrm{m} \Lambda$ ðəz slo:

ə de:n də kliər ðə nə:Its dim skə:I

(w)u:n sta:r də zink ən (w)uin gu: hə:I

ən livən gifts ə ju: $\theta$ də va:l

vrəm gə:rt to sma:l bət nevər də:I

on Sud ə:I vju:

(h)wpt gpd mid du:

wi dzæi ər pæIn wi pæIn ər dzæI 
THE RWOSE IN THE DARK

IN zummer, leäte at evenèn tide,

I zot to spend a moonless hour sat

'Ithin the window, wi' the zide

A-bound wi' rwoses out in flow'r,

Bezide the bow'r, vorsook o' birds,

An' listen'd to my true-love's words.

A-risèn to her comely height,

She push'd the swingèn ceäsement round;

And I could hear, beyond my zight,

The win'-blow'd beech-tree softly sound,

On higher ground, a-swaÿèn slow,

On drough my happy hour below.

through

An' tho' the darkness then did hide

The dewy rwose's blushèn bloom,

He still did cast sweet aïr inside

it

To Jeäne, a-chattèn in the room;

An' though the gloom did hide her feäce,

Her words did bind me to the pleäce.

An' there, while she, wi' runnèn tongue,

Did talk unzeen 'ithin the hall,

I thought her like the rwose that flung

His sweetness vrom his darken'd ball,

'Ithout the wall, an' sweet's the zight

Ov her bright feäce by mornèn light. 
ðə ruəz in ðə da:rk

In zムmər ljet ət iivmən tə:Id

ə:I zat to $\operatorname{spcn}(\mathrm{d})$ ə mu:nlis ə:uər

IðIn ðə windər wi ðə zə:Id

əbə:un(d) wi ruəziz ə:ut in flə:uər

bizə:Id ðə bə:uər varsuk ə bə:rdz

ən lisənd to mə:I tru:l $\Lambda \mathrm{vz}$ wə:rdz

ərə:Izən tu (h)ər kımli hə:It

ji: puft ðə swinən kjesmənt rə氵un(d)

ən(d) ə:I kud hiər bijand mə:I zə:It

ðə winblo:d bittftri: spf(t)li sə:un(d)

pn hə:ıər grə:un(d) əswæiən slo:

pn dru: mə:I hapi ə:uər bilo:

ən ðо: ðə da:rknıs ðعn did hə:Id

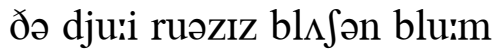

hi: strl did kaist swi(:)t æir Insə:Id

tə dzjen ət $\int a t ə n$ in ðə ru:m

ən ðо: ðə glu:m did hə:Id (h)ər fjes

(h)ər wə:rdz did bə:ın(d) mi: tə ðə pljes

ən ðər (h)wə:ıl Si: wi rınən t $\Lambda$ y

dıd te:k $\Lambda$ nzi:n Iðın ðə ha:l

ə:I ðว:t (h)ər lik ðə ruəz ðət flı

(h)Iz swi(:)tnis vrəm (h)Iz da:rkənd ba:l

ıðə:ut ðə wa:l ən swi(:)ts ðə zə:It

əv (h)ər brə:It fjes b(ə:)I ma:rnən lə:It 
COME

Wull ye come in eärly Spring,

Come at Easter, or in Maÿ?

Or when Whitsuntide mid bring

may

Longer light to show your waÿ?

Wull ye come, if you be true,

Vor to quicken love anew?

Wull ye call in Spring or Fall?

Come now soon by zun or moon?

Wull ye come?

Come wi' vaïce to vaïce the while

All their words be sweet to hear;

Come that feäce to feäce mid smile,

While their smiles do seem so dear;

Come within the year to seek

Woone you have sought woonce a week?

Come while flow'rs be on the bow'rs,

And the bird o' zong's a-heärd.

Wull ye come?

Ees come to ye, an' come vor ye, is my word,

I wull come. 
$\mathrm{k} \wedge \mathrm{m}$

wul i: k^m In jə:rli sprin

kım ət isstər ar in mæi

ar (h)wen (h)witsəntə:Id mid brin

lpygər ləit to fo: jər wæI

wol i: kım If ju: bi: tru:

var to kwikən $1 \Lambda$ v ənju:

wol i: ka:l in sprin ar fa:l

kım nə:u su:n b(ə:) I z $\wedge$ ar mu:n

wul i: kım

kım wi væIs tə væIs ðə (h)wə:ıl

a:l ðər wərrdz bi: swi(:)t to hiər

kım ðət fjes tə fjes mid smə:Il

(h)wə:Il ðər smə:Ilz də si(:)m sə diər

kım (w)rðIn ðə jiər tə si:k

(w)u:n jə hav so:t (w)uins ə wi(:)k

k^m (h)wə:Il flə;uərz bi: pn ðə bə:uərz

ən(d) ðə bə:rd ə zpyz əhjə:rd

wul i: kım

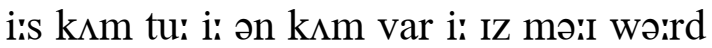

ə:I wul kım 


\section{ZUMMER WINDS}

LET me work, but mid noo tie

may

Hold me vrom the oben sky,

When zummer winds, in plaÿsome flight,

Do blow on vields in noon-day light,

Or ruslèn trees, in twilight night.

Sweet's a stroll,

By flow'ry knowl, or blue-feäc'd pool

That zummer win's do ruffle cool.

When the moon's broad light do vill

Plaïns, a-sheenèn down the hill;

shining

A-glitterèn on window glass,

O then, while zummer win's do pass

The rippled brook, an' swaÿèn grass,

Sweet's a walk,

Where we do talk, wi' feäces bright,

In whispers in the peacevul night.

When the swaÿèn men do mow

Flow'ry grass, wi' zweepèn blow,

In het a-most enough to dry

beat

The flat-spread clote-leaf that do lie

yellow water-lily

Upon the stream a-stealèn by,

Sweet's their rest,

Upon the breast o' knap or mound

billock

Out where the goocoo's vaïce do sound.

cuck.oo's

Where the sleek-heäir'd maïd do zit

Out o' door to zew or knit,

Below the elem where the spring

'S a-runnèn, an' the road do bring

The people by to hear her zing, 


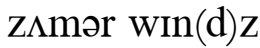

let mi: wərk bət mid nu: tə:I huəld mi: vrəm ði o:bən skə:I (h)wen z^mər win(d)z in plæIsəm flə:It do blo: pn vi:l(d)z in nuinde: lə:it ar ruslən tri:z in twə:Ilə:It nə:It swi(:)ts a stro:l b(ə:)I flə:uri no:l ar blu:fjest pu:l ðət z^mər win(d)z də r $\Lambda$ fəl ku:l

(h)wعn ðə mu:nz bro:d lə:It də vil

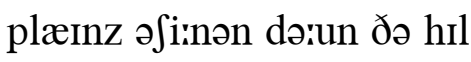
əglitərən pn windər gla:s o: ðعn (h)wə:Il z^mər win(d)z də pa:s ðə ripəld bruk ən swæiən gra:s swi(:)ts a we:k (h)wər wi: də te:k wi fjesız brə:It In (h)wispərz in ðə pissvul nə:It

(h)wen ðə swæIən men də mo: flə:uri gra:s wi zwi:pən blo: In het a:məst in $\Lambda$ fo drə:I ðə flatspred klo:tliff ðət də lə:I әpрn ðə stri:m əsti:lən bə:I swi(:)ts ðər rest əppn ðə brest ə nap ər mə:un(d) ə:ut (h)wər ðə guku:z væIs də sə:un(d)

(h)wər ðə sli:khjeərd mæId də zIt ə:ut a duor to zo: or nit bılo: ði عləm (h)wər ðə sprin z ərムnən ən ðə ro:d də brin ðə pi:pəl bə:I tə hiər (h)ər zIn 
On the green,

Where she's a-zeen, an' she can zee,

O gaÿ is she below the tree.

Come, O zummer wind, an' bring

Sounds o' birds as they do zing,

An' bring the smell o' bloomèn maÿ,

An' bring the smell o' new-mow'd hä̈;

Come fan my feäce as I do straÿ,

Fan the heäir

O’ Jessie feäir; fan her cool,

By the weäves o' stream or pool. 
pn ðə gri:n

(h)wər Ji:z əzi:n ən Ji: kən zi:

o: gæI IZ Ji: bılo: ðə tri:

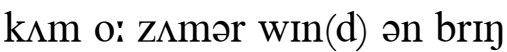
sə:un(d)z ə bə:rdz əz ðe: də zIn ən brin ðə smel ə blu:mən mæI ən brin ðə smel ə nju: mo:d hæI k^m fan mə:I fjes əZ əII də stræI fan ठə hjeər ə dzesi fjeər fan (h)ər ku:l b(ə:)I ðə wjevz ə stri:m ər pu:l 
WHEN high-flown larks wer on the wing,

A warm-aïr'd holiday in Spring,

We stroll'd, 'ithout a ceäre or frown,

Up roun' the down at Meldonley;

An' where the hawthorn-tree did stand

Alwone, but still wi' mwore at hand,

We zot wi' sheädes o' clouds on high sat, shadows

A-flittèn by, at Meldonley.

An' there, the while the tree did sheäde

Their gigglèn heads, my knife's keen bleäde

Carved out, in turf avore my knee,

J. L., * T. D., at Meldonley.

’Twer Jessie Lee J. L. did meän,

T. D. did stan' vor Thomas Deäne;

The "L" I scratch'd but slight, vor he

Mid soon be $\mathrm{D}$, at Meldonley.

might

An' when the vields o' wheat did spread

Vrom hedge to hedge in sheets o' red,

An' bennets wer a-sheäkèn brown,

Upon the down at Meldonley,

We stroll'd ageän along the hill,

An' at the hawthorn-tree stood still,

To zee J. L. vor Jessie Lee,

An' my T. D., at Meldonley.

The grey-poll'd bennet-stems did hem

grey-headed

Each half-hid letter's zunken rim,

By leädy's-vingers that did spread

grass-stalks

In yollow red, at Meldonley. 
ðə njєm letərz

(h)wen hə:Iflo:n la:rks wər pn ðə win

ə wa:rmærrd hplide: in sprin

wi: stro:ld ıðə:ut ə kjeər ər frə:un

$\Lambda p$ rə:un ðə də:un ət meldənli:

ən (h)wər ðə hع:ða:rntri: did stan(d)

əluən bət strl wi muər ət han(d)

wi: zat wi $\int j \varepsilon d z$ ə klə:udz pn hə:I

əflitən bə:I ət meldənli:

ən ðər ðə (h)wə:Il ðə tri: did $\int j \varepsilon d$ ðər giglən hedz mə:I nə:Ifs ki:n bljed ka:rvd ə:ut In tə:rf əvuər mə:I ni:

dze: $\varepsilon 1$ ti: di: ot meldənli: twər dzesi li: dze: $\varepsilon l$ did miən ti: di: did stan vor toməs diən ði $\varepsilon$ l əiI skratft bət slə:It vər hi: mid suin bi: di: ət meldənli:

ən (h)wعn ठə vill(d)z ə (h)wi:t did spred vrəm hedz to hedz In Ji:ts ə red ən benits wər əरjekən brə:un əppn ðə də:un ət meldənli: wi: stro:ld əgjen əlpy ðə hıl ən at ðə hع:ða:rntri: stud stıl tə zi: dze: $\varepsilon$ l vər dzesi li: ən mə:I ti: di: ət meldənli:

ðə gre:po:ld benitstemz did hem i:t he:fhid letərz z^ykən rIm b(ə:)I ljedizvingərz ðət did spred In jalər red ət meldənli: 
An' heärebells there wi' light blue bell

Shook soundless on the letter $\mathrm{L}$,

To ment the bells when $\mathrm{L}$ vor Lee

imitate

Become a $\mathrm{D}$ at Meldonley.

Vor Jessie, now my wife, do strive

Wi' me in life, an' we do thrive;

Two sleek-heäired meäres do sprackly pull

horses, briskly

My waggon vull, at Meldonley;

An' small-hoofd sheep, in vleeces white,

Wi' quickly-pankèn zides, do bite

panting

My thymy grass, a-mark'd vor me

In black, T.D., at Meldonley. 
ən hjeərbelz ðər wi lə:It blu: bel

Suk sərun(d)les pn ðə letər $\varepsilon$ l

tə ment ðə belz (h)wen عl vər li:

bikım ə di: ət meldənli:

vər dzesi nə:u mə:I wə:If də strə:IV

wi mi: in lə:If ən wi: də $\theta$ rə:Iv

tu: sli:khjeərd mjeərz də sprakli pul

mə:I wagən vul ət meldənli:

ən sma:lh $\Lambda \mathrm{ft} \int \mathrm{i}: \mathrm{p}$ in vlissız (h)wərit

wi kwrklipaykən zə:Idz də bə:It

mə:I tə:Imi gra:s əma:rkt vər mi:

In blak ti: di: ot meldənli: 
AH! when our wedded life begun,

Theäse cleän-wall'd house of ours wer new;

this
yellow

Wi' thatch as yollor as the zun

Avore the cloudless sky o' blue;

The sky o' blue that then did bound

The blue-hilled worold's flow'ry ground.

An' we've a-vound it weather-brown'd,

As Spring-tide blossoms oben'd white,

Or Fall did shed, on zunburnt ground,

Red apples from their leafy height:

Their leafy height, that Winter soon

Left leafless to the cool-feäced moon.

An' raï-bred moss ha' staïn'd wi' green

The smooth-feäced wall's white-morter'd streaks,

The while our childern zot between

Our seats avore the fleäme's red peaks:

The fleäme's red peaks, till axan white

ashes

Did quench em vor the long-sleep'd night.

The bloom that woonce did overspread

once

Your rounded cheäk, as time went by,

A-shrinkèn to a patch o' red,

Did feäde so soft's the evenèn sky:

The evenèn sky, my faithful wife,

O' days as feäir's our happy life. 
ðə nju: hə:us əgetən (w)uəld

a: (h)wen ə:uər wedıd lə:ıf big $n$

ðiəs klinnwa:ld hə:us əv ə‘uərz wər nju:

wi ðat $\int \mathrm{z}$ jalər əz ðə zムn

əvuər ðə klə:udlıs skə:I ə blu:

ðə skə:I ə blu: ðət ðعn did bə:un(d)

ðə blu:hıld wə:rdəlz flə:uri grə:un(d)

ən wi:v əvə:un(d) it weðərbrə:und

əz sprintə:Id blpsəmz o:bənd (h)wə:It

ar fa:l did $\int \varepsilon d$ pn zınbərrnt grə:und

red apəlz vrəm ðər li:fi hə:It

ðər li:fi hə:It ðət wintər su:n

left li:flıs tə ðə kuilfjest mu:n

ən ræinbred mps hə stæInd wi gri:n

ðə smu:ðfjest wa:lz (h)wə:Itma:rtərd striks

ðə (h)wə:Il ə:uər tfrldərn zat bitwi:n

ə:uər si:ts əvuər ðə fljemz red pi:ks

ðə fljemz red pi:ks tıl aksən (h)wə:It

did kwent $\int$ əm vər ðə lpysli:pt nə:It

ðə blu:m ðət (w)uins did ə:vərspred

jər rə:undid t $f i ə k$ əz tə:Im went bə:I

əरrinkən tu $ə$ pat $\int$ ə red

did fjed sə spf(t)s ði i:vmən skə:I

ði i:vmən skə:I mə:I fæi $\theta v u l$ wə:If

ə de:z əz fjeərz ə:uər hapi lə:If 
IN zummer, when the sheädes do creep

shadows

Below the Zunday steeple, round

The mossy stwones, that love cut deep

Wi' neämes that tongues noo mwore do sound,

The leäne do lose the stalkèn team,

An' dry-rimm'd waggon-wheels be still,

An' hills do roll their down-shot stream

Below the restèn wheel at mill.

O holy day, when tweil do ceäse,

toil

Sweet day o' rest an' greäce an' peäce!

The eegrass, vor a while unwrung

By hoof or shoe, 's a sheenèn bright, grass regrown after mowing shining An' clover flowers be a-sprung

On new-mow'd knaps in beds o' white, billocks

An' sweet wild rwoses, up among

The hedge-row boughs, do yield their smells,

To aïer that do bear along

The loud-rung peals o' Zunday bells,

Upon the day o' days the best,

The day o' greäce an' peäce an' rest.

By brightshod veet, in peäir an' peäir,

Wi' comely steps the road's a-took

To church, an' work-free han's do beär

Woone's walkèn stick or sister's book;

one's

An' there the bloomèn niece do come

To zee her aunt, in all her best;

Or married daughter do bring hwome

Her vu'st sweet child upon her breast, first

As she do seek the holy pleäce,

The day o' rest an' peäce an' greäce. 
zınde:

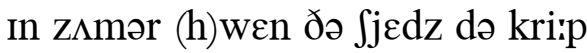

bilo: ðə zınde: sti:pəl rə:un(d)

ðə mpsi stuənz ðət $1 \Lambda \mathrm{v}$ k $\Lambda$ t di:p

wi njemz dət tıyz nu: muər də sə:un(d)

ðə ljen də lu:z ðə ste:kən ti:m

ən drə:IrImd wagən(h)willz bi: stil

ən hilz də ro:l ðər də:un $\int p t$ stri:m

bilo: ðə restən (h)will ət mil

o: ho:li de: (h)wen twə:Il də siəs

swi(:)t de: ə rest ən grjes ən piəs

ði irgra:s vər ə (h)wə:Il $\Lambda$ nr $\Lambda$ y

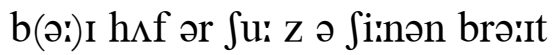

ən klə:vər flə:uərz bi: əspr $\wedge$ y

pn nju: mo:d naps in bedz ə (h)wə:It

ən swi(:)t wə:Il(d) ruəzız $\Lambda$ p əmpy

ðə hedzro: bə:uz də jiil(d) ðər smelz

tu æiər ðət də beər əlpy

ðə lə:udr $\wedge$ p pilz ə zınde: belz

әppn ðə de: ə de:z ðə best

ðə de: ə grjes ən piəs ən rest

b(ə:)I brə:It $\int p d$ vi:t In pjeər ən pjeər

wi kımli steps ðə ro:dz ətuk

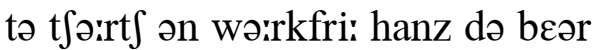

(w)u:nz we:kən stik ar sistərz buk

ən ðər ðə blu:mən ni:s də kım

tə zi: (h)ər ع:nt in a:l (h)ər best

ar marid de:tər də brin huəm

(h)ər v $\Lambda$ st swi(:)t t $\int \partial: I l(d)$ əppn (h)ər brest

əz Ji: də si:k ðə ho:li pljes

ðə de: ə rest ən piəs ən grjes 
THE PILLAR’D GEÄTE

As I come by, zome years agoo,

A-burnt below a sky o' blue,

'Ithin the pillar'd geäte there zung

A vaïce a-soundèn sweet an' young,

That meäde me veel awhile to zwim

In weäves o' jaÿ to hear its hymn;

Vor all the zinger, angel-bright,

Wer then a-hidden vrom my zight, An' I wer then too low

To seek a meäte to match my steäte

'Ithin the lofty-pillar'd geäte,

Wi' stwonèn balls upon the walls:

Oh, no! my heart, no, no.

Another time as I come by

The house, below a dark-blue sky,

The pillar'd geäte wer oben wide,

An' who should be a-show'd inside,

But she, the comely maïd whose hymn

Woonce meäde my giddy braïn to zwim,

A-zittèn in the sheäde to zew,

A-clad in robes as white as snow.

What then? could I so low

Look out a meäte ov higher steäte

So gaÿ 'ithin a pillar'd geäte,

Wi' high walls round the smooth-mow'd ground?

Oh, no! my heart, no, no.

Long years stole by, a-glidèn slow,

Wi' winter cwold an' zummer glow,

An' she wer then a widow, clad

In grey; but comely, though so sad; 
ðə pilərd gjet

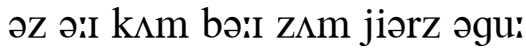

əbə:rnt bilo: a skə:I ə blu:

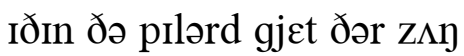

ə væIs əsə:un(d)ən swi(:)t ən j $\Lambda$ y

ðət mjed mi: vi:l ə(h)wə:Il tə zwIm

In wjevz ə dzæi to hiər Its hIm

vər a:l ðə zIyər andzəlbrə:It

wər ðદn əhIdən vrəm mə:I zə:It

ən ə:I wər ठen tu: lo:

to sikk ə mjet to mat $\int$ mə:I stjet

ıðIn ðə lpftipılərd gjet

wi stuənən ba:lz əppn ðə wa:lz

o: no: mə:I ha:rt no: no:

ən^ðər tə:Im əz ə:I kım bə:I

ðə hə:us bilo: ə da:rkblu: skə:I

ðə pilərd gjet wər o:bən wə:Id

ən hu: $\int u d$ bi: $ə \int o: d$ Insə:Id

bət Si: ðə kımli mæId hu:z hım

(w)uins mjed mə:I gidi bræIn to zwIm

əzitən in ðə $\int j \varepsilon d$ to zo:

əklad in ro:bz əz (h)wə:It əz sno:

(h)wpt ðعn kud ə:I sə lo:

luk ə:ut ə mjet əv hə:Iər stjet

sə gæı Iðın ə pilərd gjet

wi hə:I wa:lz rə:un(d) ðә smu:ðmo:d grə:un(d)

o: no: mə:I ha:rt no: no:

loy jiərz sto:l bə:I əglə:Idən slo:

wi wintər kuəld ən zımər glo:

ən $\int \mathrm{i}:$ wər ठعn ə widər klad

In gre: bət kımli ðo: sə sad 
Her husband, heartless to his bride,

Spent all her store an' wealth, an' died;

Though she noo mwore could now rejaïce,

Yet sweet did sound her zongless vaïce.

But had she, in her woe,

The higher steäte she had o' leäte

'Ithin the lofty pillar'd geäte,

Wi' stwonèn balls upon the walls?

Oh, no! my heart, no, no.

But while she vell, my Meäker's greäce

Led me to teäke a higher pleäce,

An' lighten'd up my mind wi' lore,

An' bless'd me wi' a worldly store;

But still noo winsome feäce or vaïce,

Had ever been my wedded chaïce;

An' then I thought, why do I mwope

Alwone without a jaÿ or hope?

Would she still think me low?

Or scorn a meäte, in my feäir steäte,

In here 'ithin a pillar'd geäte,

A happy pleäce wi' her kind feäce?

Oh, no! my hope, no, no.

I don't stand out 'tis only feäte

maintain

Do gi'e to each his wedded meäte;

give

But eet there's woone above the rest, yet, one

That every soul can like the best.

An' my wold love's a-kindled new,

An' my wold dream's a-come out true;

But while I had noo soul to sheäre

share

My good an' ill, an' jäy an ceäre,

joy

Should I have bliss below, 
(h)ər hızbən(d) ha:rtlis tu (h)Iz brə:Id

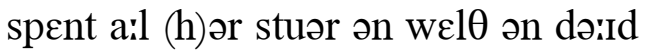
ðo: $\int i:$ nu: muər kud nə:u ridzæIs i:t swi(:)t did sə:un(d) (h)ər zpylis væIs bət had Si: in (h)ər wo:

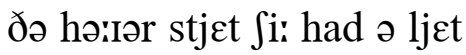
ıðın ðə lpfti pilərd gjet wi stuənən ba:lz əppn ðə wa:lz o: no: mə:I ha:rt no: no:

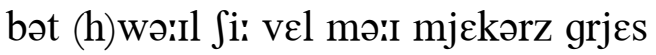
led mi: to tjek ə hə:Iər pljes ən lə:itənd $\Lambda$ p mə:I mə:In(d) wi luər ən blest mi: wi ə wərrdli stuər bət strl nu: winsəm fjes ər væIs had عvər bin mə:I wedid tfæis әn ठعn ә:I ðว:t (h)wə:I du: ə:I muәp əluən (w)ıə’ut ə dzæi ar ho:p wud Sii stıl Jınk mi: lo: ar ska:rn ə mjet in mə:I fjeər stjet In hiər IðIn ə pilərd gjet ə hapi pljes wi (h)ər kə:In(d) fjes o: no: mə:I ho:p no: no:

ə:I do:nt $\operatorname{stan}(\mathrm{d})$ ə:ut tIz o:nli fjet də gi: tu i:t (h)Iz wedid mjet bət i:t ðərz (w)u:n əb $\Lambda \mathrm{v}$ ðə rest ðət عvri so:l kən lə:ik ðə best ən mə:I (w)uəld $1 \Lambda \mathrm{vz}$ əkindəld nju: ən mə:I (w)uəld driimz əkım ərut tru: bət (h)wə:Il ə:I had nu: so:l tə fjeər mə:I gud ən il ən dzæi ən kjeər ऽud ə:i hav blis bilo: 
In gleämèn pleäte an' lofty steäte

'Ithin the lofty pillar'd geäte,

Wi' feäirest flow'rs, an' ponds an' tow'rs?

Oh, no! my heart, no, no. 
In gliəmən pljet ən lpfti stjet

ıðın ðə lpfti pilərd gjet

wi fjeərəst flə:uərz ən ppn(d)z ən tə:uərz

o: no: mə:I ha:rt no: no: 
AH! then the grassy-meäded Maÿ

Did warm the passèn year, an' gleam

Upon the yellow-grounded stream,

That still by beech-tree sheädes do sträy.

shadows

The light o' weäves, a-runnèn there,

Did plaÿ on leaves up over head,

An' vishes sceäly zides did gleäre,

A-dartèn on the shallow bed,

An' like the stream a-slidèn on,

My zun-out-measur'd time's agone.

There by the path, in grass knee-high,

Wer buttervlees in giddy flight,

butterflies

All white above the deäisies white,

Or blue below the deep blue sky.

Then glowèn warm wer ev'ry brow,

O' maïd, or man, in zummer het,

beat

An' warm did glow the cheäks I met

That time, noo mwore to meet em now.

As brooks, a-slidèn on their bed,

My season-measur'd time's a-vled.

flown by

Vrom yonder window, in the thatch,

Did sound the maïdens' merry words,

As I did stand, by zingèn birds,

Bezide the elem-sheäded hatch.

wicket-gate

'Tis good to come back to the pleäce,

Back to the time, to goo noo mwore;

'Tis good to meet the younger feäce

A-mentèn others here avore.

taking after

As streams do glide by green mead-grass,

My zummer-brighten'd years do pass. 
a: ðعn ðə gra:simiədıd mæI dıd wa:rm ðə pa:sən jiər ən gli:m əppn ðə jalərgrə:un(d)Id stri:m ðət stıl b(ə:)I bi:t ftri: $\int j \varepsilon d z$ də stræI ðə lə:It ə wjevz ərınən ðعər did plæI pn li:vz $\Lambda$ p oivər hed ən vifız skjeli zə:Idz did gljeər əda:rtən pn ðə كalər bed ən lik ðə stri:m əslə:Idən pn

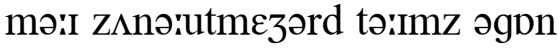

ðər b(ə:)I ðə pe: $\theta$ In gra:s ni:hə:I wər bıtərvli:z In gidi flə:It a:l (h)wə:It əbムv ðə djeziz (h)wə:It ar blu: bilo: ðə di:p blu: skə:I ðعn glo:ən wa:rm wər عvri brə:u ə mæId ər man In zımər het ən wa:rm did glo: ðə t fiəks ə:I met ðat tə:Im nu: muər to mi(:)t əm nə:u az bruks əslə:Idən pn ðər bed mə:I si:zənmezərd tə:Imz əvled

vrəm jandər windər In ðə ðat dıd sə:un(d) ðə mæıdənz meri wərrdz əz ə:I did $\operatorname{stan}(d)$ b(ə:)I zIngən bə:rdz

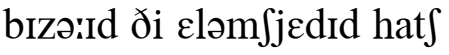
tız gud to kım bak to ठə pljes bak to ðə tə:Im to gu: nu: muər tIz gud tə mi(:)t ðə j $\Lambda$ ggər fjes әmєntən $\Lambda$ ðrz hiər əvuər az stri:mz də glə:Id b(ə:)I gri:n miədgra:s mə:I Zムmərbrə:Itənd jiərz də pa:s 
THE bright-tunn'd house, a-risèn proud, -chimneyed

Stood high avore a zummer cloud, An' windy sheädes o' tow'rs did vall shadows

Upon the many-window'd wall;

An' on the grassy terrace, bright

Wi' white-bloom'd zummer's deäisy beds, An' snow-white lilies' noddèn heads,

Sweet Linda Deäne did walk in white;

But ah! avore too high a door,

Wer Linda Deäne ov Ellendon.

When sparklèn brooks an' grassy ground, By keen-aïr'd Winter's vrost wer bound, An' star-bright snow did streak the forms O' beäre-lim'd trees in darksome storms, bare-limbed

Sweet Linda Deäne did lightly glide,

Wi' snow-white robe an' rwosy feäce,

Upon the smooth-vloor'd hall, to treäce

The merry dance o' Chris'mas tide;

But oh! not mine be balls so fine

As Linda Deäne's at Ellendon.

Sweet Linda Deäne do match the skies

Wi' sheenèn blue o' glisnèn eyes, shining An' feäirest blossoms do but show

Her forehead's white, an' feäce's glow;

But there's a winsome jaÿ above,

The brightest hues ov e'th an' skies.

The dearest zight o' many eyes,

Would be the smile o' Linda's love;

But high above my lowly love

Is Linda Deäne ov Ellendon. 
lində diən

ðə brə:It tınd hə:us ərə:Izən prə:ud stud hə:I əvuər ə zımər klə:ud ən windi $\int j \varepsilon d z$ ə tə:uərz did va:l әppn ðə meniwindərd wa:l ən pn ðə gra:si terəs brə:It wi (h)wə:Itblu:md zımərz djezi bedz ən sno:(h)wə:It liliz nodən hedz swi(:)t lində diən did we:k in (h)wə:It bət a: əvuər tu: hə:I ə duər wər lində diən əv عləndən

(h)wen sparklən bruks ən gra:si grə:un(d) b(ə:)I ki:næIrd wintərz vrost wər bə:un(d) ən sta:rbrə:It sno: did stri:k ðə fa:rmz ə bjeərlımd tri:z in da:rksəm sta:rmz swi(:)t lində diən did lə:itli glə:Id wi sno:(h)wə:It ro:b ən ruəzi fjes әppn ðə smu:ðvluərd ha:l tə trjes ðə meri de:ns ə krisməs tə:Id bət o: npt mə:In bi: ba:lz sə fə:In əz lində diənz ət عləndən

swi(:)t lində diən də mat ðə skə:Iz wi finən blu: a glisnən ə:Iz ən fjeərəst blosəmz də bət $\int o$ : (h)ər fpridz (h)wə:It on fjesız glo: bət dərz ə winsəm dzæi əb ðə brə:ItIst hju:z əv $\varepsilon \theta$ ən skə:Iz ðə diərıst zə:It ə meni ə:IZ wud bi: ðə smə:ıl ə lindəz $1 \Lambda \mathrm{v}$ bət hə:I əbムv mə:I lo:li $1 \Lambda \mathrm{v}$ Iz lində diən əv عləndən 
ECLOGUE

COME AND ZEE US IN THE ZUMMER

John; William; William's Bwoy; and William's Maïd at Feä̈r

son, daughter

JOHN

Zoo here be your childern, a-sheärèn

Your feäir-day, an' each wi' a feäirèn.

so, sharing

gift bought at the fair

WILLIAM

Aye, well, there's noo peace 'ithout comèn

To stannèn an' show, in the zummer.

stall

JOHN

An' how is your Jeäne? still as merry

As ever, wi' cheäks lik' a cherry?

WILLIAM

Still merry, but beauty's as feädesome

'S the raïn's glowèn bow in the zummer.

rainbow

JOHN

Well now, I do hope we shall vind ye

Come soon, wi' your childern behind ye,

To Stowe, while o' bwoth zides o' hedges,

The zunsheen do glow in the zummer.

sunshine

\section{WILLIAM}

Well, aye, when the mowèn is over,

An' ee-grass do whiten wi' clover.

grass regrown after mowing

A man's a-tired out, vor much walken,

The while he do mow in the zummer. 
$\varepsilon k \operatorname{lng}$

$\mathrm{k} \Lambda \mathrm{m}$ ən(d) zi: əs In ðə zımər

dzan wiləm wiləmz bwə: ən(d) wiləmz mæid ət fjeər

JOHN

zu: hiər bi: jər $\mathrm{t} \int \mathrm{Ild}$ ldrn $ə \int \mathrm{j} \varepsilon ə r ə n$

jər fjeərde: ən i:t $\int$ wi ə fjeərən

WILLIAM

æI wel ðərz nu: piss Iðə:ut kımən

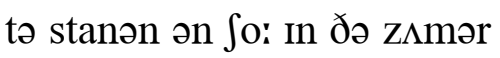

JOHN

ən hə:u Iz jər d3jen strl əz meri

əz Evər wi t fiəks lik a t $\int \varepsilon r i$

WILLIAM

stıl meri bət bju:tiz əz fjedsəm

z ðə ræInz glo:ən bo: In ðə z^mər

JOHN

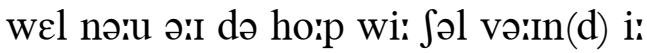

kım su:n wi jər t fildərn bihə:In(d) i:

tə sto: (h)wə:Il ə buəð zə:Idz ə hedzIz

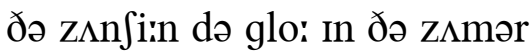

WILLIAM

wel æI (h)wen ðə mo:ən IZ ว:vər

ən i:gra:s də (h)wə:itən wi klo:vər

ə manz ətə:Iərd ə:ut vər $\mathrm{m} \Lambda \mathrm{t} \int \mathrm{w}$ w:kən

ðə (h)wə:Il hi: də mo: In ðə zımər 
I'll goo, an' we'll zet up a wicket, An' have a good innèns at cricket;

An' teäke a good plounce in the water,

Where clote-leaves do grow in the zummer.

I'll goo, an' we'll plaÿ “Thread the needle"

Or "Huntèn the slipper," or wheedle

Young Jemmy to fiddle, an' reely

So brisk to an' fro in the zummer.

\section{JOHN}

An' Jeäne. Mind you don't come 'ithout her,

My wife is a-thinkèn about her;

At our house she'll find she's as welcome

'S the rwose that do blow in the zummer. 
WILLIAM'S BWOY

ว:Il gu: ən wiil zet $\Lambda$ p ə wikıt

on hav $ә$ gud inənz ət krikit

ən tjek ə gud plə:uns in ðə wə:tər

(h)wər klo:tli:vz də gro: In ðə zムmər

WILLIAM'S MAID

ə:Il gu: ən wi:l plæı dred ðə ni:dəl

ar hıntən ðə slipər ar (h)wi:dəl

$\mathrm{j} \Lambda \mathrm{y} \mathrm{d} z \varepsilon m i$ tə fidəl on riili

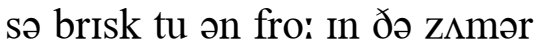

JOHN

ən dzjen mə:in(d) jə do:nt kım ıðə:ut hər

mə:I Wə:If IZ əðı๊kən əbə:ut hər

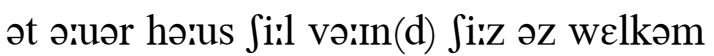

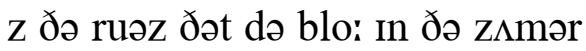




\section{LINDENORE}

AT Lindenore upon the steep,

Bezide the trees a-reachèn high,

The while their lower limbs do zweep

The river-stream a-flowèn by;

By grægle bells in beds o' blue,

bluebell

Below the tree-stems in the lew, shelter

Calm air do vind the rwose-bound door,

Ov Ellen Dare o’ Lindenore.

An' there noo foam do hiss avore

Swift bwoats, wi' water-plowèn keels,

An' there noo broad high-road's a-wore

By vur-brought trav'lers' cracklèn wheels;

from afar

Noo crowd's a-passèn to and fro,

Upon the bridge's high-sprung bow:

$\operatorname{arch}$

An' vew but I do seek the door

Ov Ellen Dare o’ Lindenore.

Vor there the town, wi' zun-bright walls,

Do sheen vur off by hills o' grey,

shine

An' town-vo'k ha' but seldom calls

-folk

O' business there, from day to day:

But Ellen didden leäve her ruf

didn't, roof

To be admir'd, an' that's enough-

Vor I've a-vound 'ithin her door,

Feäir Ellen Dare o’ Lindenore. 
lindənuər

ət lindənuər əppn ðə sti:p

bizə:Id ðə triiz ərittðən hə:I

ðə (h)wə:Il ðər lo:ər limz də zwi:p

ðə rIvərstri:m əflo:ən bə:I

b(ə:)I gre:gəl belz in bedz ə blu:

bilo: ðə tristemz in ðə lu:

ka:m æIr də və:In(d) ðə ruəzbə:un(d) duər

əv عlən djeər ə lindənuər

ən ðər nu: fo:m də his əvuər

$\operatorname{swIf(t)} b(w)$ uəts wi wo:tərplə:uən ki:lz

ən ðər nu: bro:d hə:Iro:dz əwuər

b(ə:)I və:rbro:t travlərz kraklən (h)willz

nu: krə:udz əpa:sən tu: ən(d) fro:

әppn ðə brıdżz hə:Isprıy bo:

ən vju: bət ə:I də si:k ðə duər

əv عlən djeər ə lindənuər

vər ðər ðə tə:un wi zınbrə:It wa:lz

də Siin və:r of b(ə:)I hilz ə gre:

ən tə:unvo:k ha bət seldəm ka:lz

a biznis ðər vrəm de: tə de:

bət عlən didən liəv (h)ər $\mathrm{r} \Lambda \mathrm{f}$

to bi: ədmə:Ird ən ðats in $\Lambda f$

vər ə:IV əvə:un(d) IðIn (h)ər duər

fjeər عlən djeər ə lindənuər 
O WHEN theäse elems' crooked boughs, this A'most too thin to sheäde the cows, Did slowly swing above the grass As winds o' Spring did softly pass, An' zunlight show'd the shiftèn sheäde, While youthful me'th wi' laughter loud, Did twist his lim's among the crowd Down there below; up there above Wer bright-ey'd me'th below the tree.

Down there the merry vo'k did vill folk The stwonèn doorway, now so still; An' zome did joke, wi' ceäsement wide, Wi' other vo'k a-stood outside, Wi' words that head by head did heed.

Below blue sky an' blue-smok'd tun, 'Twer jaÿ to zee an' hear their fun, chimney-top

But sweeter jaÿ up here above Wi' bright-ey'd me'th below the tree.

Now unknown veet do beät the vloor, An' unknown han's do shut the door, An' unknown men do ride abrode, An' hwome ageän on thik wold road, out and about Drough geätes all now a-hung anew. that old through

Noo mind but mine ageän can call

Wold feäces back around the wall, Down there below, or here above, Wi' bright-ey'd me'th below the tree.

Aye, pride mid seek the crowded pleäce may To show his head an' frownèn feäce, 
me $\theta$ bilo: ðə tri:

o: (h)wen ðiəz عləmz krukıd bə:uz a:məst tu: ठın to $\int j \varepsilon d$ ðə kə:uz did slo:li swin əbıv ðə gra:s az $\operatorname{win}(\mathrm{d}) \mathrm{z}$ ə sprin did $\operatorname{spf}(\mathrm{t}) \mathrm{li}$ pa:s

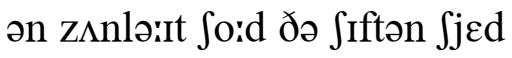

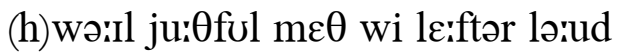
did twist (h)Iz limz əmpy ðə krə'ud də:un ðər bilo: $\Lambda$ p ðər əb $\Lambda \mathrm{V}$ wər brə:itə:Id me $\theta$ bilo: ðə tri:

də:un ðər ðə meri vo:k did vil ðə stuənən duərwə:I nə:u sə stıl ən z^m did d3o:k wi kjesmənt wə:Id wi $\Lambda$ ðr vo:k əstud ərutsə:Id wi wərrdz ठət hed b(ə:)I hed did hi:d bilo: blu: skə:I ən bluismo:kt t $\Lambda \mathrm{n}$ twər dzæi to zi: ən hiər ðər f $\Lambda \mathrm{n}$ bət swi(:)tər dzæI $\Lambda p$ hiər əb $\Lambda \mathrm{v}$ wi brə:Itə:Id me $\theta$ bilo: ðə tri:

nə:u ^nno:n vi:t də biət ðə vluər ən $\Lambda$ nno:n hanz də $\int \Lambda \mathrm{t}$ ðə duər ən $\Lambda$ nno:n men də rə:Id əbro:d ən huəm əgjen pn ðrk (w)uəld ro:d dru: gjets a:l nə:u əh^y ənju: nu: mə:In(d) bət mə:In əgjen kən ka:l (w)uəld fjesız bak ərə:un(d) дә wa:l dərun ðər bilo: ər hiər əb $\mathrm{v}$ wi brə:Itə:Id me $\theta$ bilo: ðə tri:

æI prə:Id mId si:k ðə krə:udıd pljes tə $\int o:(h) r z$ hed ən frə:unən fjes 
An' pleasure vlee, wi' goold in hand,

Vor zights to zee vrom land to land,

Where winds do blow on seas o' blue:-

Noo wealth wer mine to travel wide

Vor jaÿ, wi' Pleasure or wi' Pride:

My happiness wer here above

The feäst, wi' me'th below the tree.

The wild rwose now do hang in zight,

To mornèn zun an' evenèn light,

The bird do whissle in the gloom,

Avore the thissle out in bloom,

But here alwone the tree do leän.

The twig that woonce did whiver there

once, tremble

Is now a limb a-wither'd beäre:

bare

Zoo I do miss the sheäde above

so

My head, an' me'th below the tree. 
ən plezər vli: wi gu:ld in han(d)

vər zəits to zi: vrəm lan(d) to lan(d)

(h)wər win(d)z də blo: pn si:z ə blu:

nu: wel $\theta$ wər məin to travəl wə:Id

vər dzæI wi plezər ar wi prə:Id

mə:I hapinis wər hiər $\partial \mathrm{b} \Lambda \mathrm{v}$

ðə fiəst wi me $\theta$ bilo: ðə tri:

ðə wə:Il(d) ruəz nə:u də hay In zə:It

tə ma:rnən zムn ən i:vmən lə:it

ðə bə:rd də (h)wisəl In ðə glu:m

әvuər ðə ठısəl ə;ut In blu:m

bət hiər əluən ðə tri: də liən

ðə twig ðət (w)uins did (h)wivər ðعər

IZ nə:u ə lim əwıðərd bjeər

zu: ə:I də mIs ðə $\int j \varepsilon d ~ ə b \Lambda v$

mə:I hed ən me$\theta$ bilo: ðə tri: 
No, no, good Meäster Collins cried,

Why you've a good wife at your zide;

Zoo do believe the heart is true

That gi'ed up all bezide vor you, gave

An' still beheäve as you begun

To seek the love that you've a-won

When woonce in dewy June, once

In hours o' hope soft eyes did flash,

Each bright below his sheädy lash, A-glisnèn to the moon.

Think how her girlhood met noo ceäre

To peäle the bloom her feäce did weär,

An' how her glossy temple prest

Her pillow down, in still-feäced rest,

While sheädes o' window bars did vall

shadows

In moonlight on the gloomy wall,

In cool-aïr'd nights o' June;

The while her lids, wi' bendèn streäks

O' lashes, met above her cheäks, A-bloomèn to the moon.

Think how she left her childhood's pleäce, An' only sister's long-known feäce, An' brother's jokes so much a-miss'd, An' mother's cheäk, the last a-kiss'd;

An' how she lighted down avore

Her new abode, a husband's door,

Your weddèn night in June;

Wi' heart that beät wi' hope an' fear,

While on each eye-lash hung a tear, A-glisnèn to the moon. 
tri:t wel jər wə:If

no: no: gud mja:stər kplinz krə:Id

(h)wə:I ju:v ə gud wə:If ət jər zə:Id

zu: du: bilisv ðə hairt Iz tru:

ðət gi:d $\Lambda p$ a:l bizə:Id vər ju:

ən stıl bihjev əz jə big n

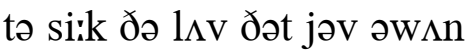

(h)wen (w)u:ns in djui dzu:n

In ə:uərz ə ho:p spft ə:Iz did flas

i:t bra:It bilo: (h)Iz Jjedi las

әglisnən tə ðə mu:n

ðınk hə:u (h)ər gə:rlhud met nu: kjeər

tə pjel ðə blu:m (h)ər fjes did weər

ən həuu (h)or glpsi tempəl prest

(h)ər pilər də:un in strlfjest rest

(h)wə:Il jjedz ə windər ba:rz did va:l

In mu:nlə:It pn ðə glu:mi wa:l

In ku:lærrd nə:ts ə dzuin

ðə (h)wə:Il (h)ər lidz wi bendən striəks

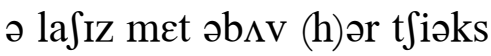

əblu:mən tə ठə mu:n

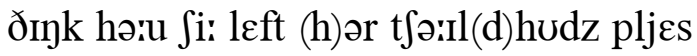

ən o:nli sistərz lpyno:n fjes

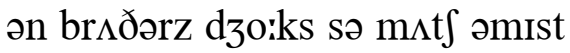

ən m^ðərz t fiək ðə le:st əkıst

ən hə:u Si: lə:ItId də:un əvuər

(h)ər nju: əbo:d ə h^zbən(d)z duər

jər wedən nə:It in dzuin

wi hairt ðət biət wi ho:p ən fiər

(h)wə:Il pn i:t ərilas hıy ə tiər

aglisnən tə ðə mu:n 
Think how her father zot all dum',

A-thinkèn on her, back at hwome,

The while grey axan gather'd thick,

ashes

On dyèn embers, on the brick;

An' how her mother look'd abrode,

out

Drough window, down the moon-bright road,

through

Thik cloudless night o' June,

that

Wi' tears upon her lashes big

As raïn-drops on a slender twig,

A-glisnèn to the moon.

Zoo don't zit thoughtless at your cup

so

An' keep your wife a-wäitèn up,

The while the clock's a-tickèn slow

The chilly hours o' vrost an' snow,

Until the zinkèn candle's light

Is out avore her drowsy sight,

A-dimm'd wi' grief too soon;

A-leävèn there alwone to murn

mourn

The feädèn cheäk that woonce did burn,

fading, once

A-bloomèn to the moon. 
ðınk hə:u (h)ər fe:ðər zat a:l d $\Lambda \mathrm{m}$ əðınkən pn hər bak ət huəm ðə (h)wəril gre: aksən gaðərd $\theta_{\mathrm{rk}}$ pn də:ıən embərz pn ðə brik ən hə:u (h)ər m^ðər lukt əbro:d dru: windər də:un ðə mu:nbrə:It ro:d ðIk klə:udlıs nə:It ə dzu:n wi tiərz əppn (h)ər la la iz big əz ræIndraps pn ə slendər twig əglisnən tə ðə mu:n

zu: do:nt zit $\theta$ ortlis at jər k $\wedge p$ ən ki(:)p jər wə:If əwæitən $\Lambda \mathrm{p}$ ðə (h)wə:ıl ðə klpks ətıkən slo: ðə tfrli ə:uərz ə vrost ən sno: ıntıl ðə zınkən kandəlz lə:It IZ ə'ut əvuər (h)ər drə:uzi zə:It adimd wi griff tu: suin əliəvən ðər əluən tə mə:rn ðə fjedən t $\int i ə k$ ðət (w)u:ns did bə:rn əblu:mən tə ठə mu:n 
O, AYE! they had woone child bezide, An' a finer your eyes never met,

'Twer a dear little fellow that died

In the zummer that come wi' such het;

beat

By the mowers, too thoughtless in fun,

He wer then a-zent off vrom our eyes,

Vrom the light ov the dew-dryèn zun,-

Aye! vrom days under blue-hollow'd skies.

He went out to the mowers in meäd,

When the zun wer a-rose to his height,

An' the men wer a-swingèn the sneäd,

Wi' their eärms in white sleeves, left an' right;

scythe bandle

An' out there, as they rested at noon,

O! they drench'd en vrom eäle-horns too deep,

Till his thoughts wer a-drown'd in a swoon;

arms

Aye! his life wer a-smother'd in sleep.

Then they laid en there-right on the ground,

On a grass-heap, a-zweltrèn wi' het,

Wi' his heäir all a-wetted around

His young feäce, wi' the big drops o' zweat;

In his little left palm he'd a-zet,

Wi' his right hand, his vore-vinger's tip,

As for zome'hat he woulden vorget,-

Aye! zome thought that he woulden let slip.

Then they took en in hwome to his bed,

An' he rose vrom his pillow noo mwore,

Vor the curls on his sleek little head

To be blown by the wind out o' door. 


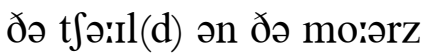

o: æı ðe: had (w)u:n tfə:Il(d) bIzə:Id

ən ə fə:Inər jər ə:Iz nevər met

twər a diər litəl felər ðət də:Id

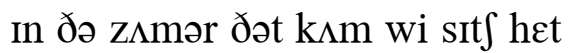

b(ə:)I ठə mo:ərz tu: $\theta$ o:tlis in f $\Lambda \mathrm{n}$

hi: wər ðعn əzent pf vrəm ə:uər ə:Iz

vrəm ðə lə:It əv ðə dju:drə:ıən zムn

æI vrəm de:z $\Lambda$ ndər blu:hplərd skə:Iz

hi: went ərut to ठə mo:ərz In miəd

(h)wen ðə zın wər əro:z tə (h)Iz hə:It

ən ðə men wər əswinən ðə sniəd

wi ðər ja:rmz in (h)wə:It sli:vz left ən rə:It

ən ə:ut ðər əz ðe: restıd ət nu:n

o: ðe: drentft ən vrəm jelharrnz tu: di:p

til (h)Iz ðo:ts wər ədrə:und in ə swu:n

æI (h)Iz lə:If wər əsm^ðərd In sli:p

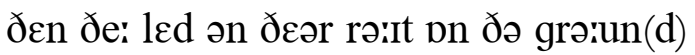

pn o graishi:p əzweltron wi het

wi (h)Iz hjeər a:l awetıd ərə:un(d)

(h)Iz j^y fjes wi ðə bıg draps ə zwet

In (h)Iz litəl left pa:m hi:d əzet

wi (h)Iz rə:It han(d) (h)Iz vuərvingərz tip

az vər z^mət hi: (w)Udən vərget

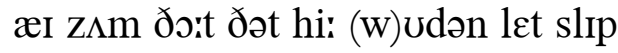

ðعn ðe: tuk ən In huəm tu (h)Iz bed

ən hi: ro:z vrəm (h)Iz pilər nu: muər

vər ðə kə:rlz pn (h)Iz slisk litəl hed

tə bi: blo:n b(ə:)I ðə wIn(d) ə'ut ə duər 
Vor he died while the häy russled grey

On the staddle so leätely begun:

baystack-base

Lik' the mown-grass a-dried by the day,-

Aye! the zwath-flow'r's a-killed by the zun. 
vər hi: də:Id (h)wə:Il ðə hæI rısəld gre:

pn ðə stadəl sə ljetli big $\Lambda$ n

lik ðə mo:ngra:s ədrə:Id b(ə:)I ðə de:

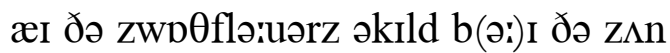


WHERE the bridge out at Woodley did stride,

Wi' his wide arches' cool sheäded bow, span

Up above the clear brook that did slide

By the popples, befoam'd white as snow:

As the gilcups did quiver among pebbles

The white deäisies, a-spread in a sheet, There a quick-trippèn maïd come along,Aye, a girl wi' her light-steppèn veet.

An' she cried "I do praÿ, is the road

Out to Lincham on here, by the meäd?" An' "oh! ees," I meäde answer, an' show'd yes

Her the way it would turn an' would leäd:

"Goo along by the beech in the nook,

Where the childern do plaÿ in the cool, To the steppèn stwones over the brook,Aye, the grey blocks o' rock at the pool."

Then, "You don't seem a-born an' a-bred,"

I spoke up, "at a place here about;" An' she answer'd wi' cheäks up so red

As a pi'ny but leäte a-come out, "No, I liv'd wi' my uncle that died Back in Eäpril, an' now I'm a-come Here to Ham, to my mother, to bide,Aye, to her house to vind a new hwome."

I'm asheämed that I wanted to know Any mwore of her childhood or life, But then, why should so feäir a child grow

Where noo father did bide wi' his wife; 


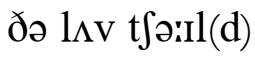

(h)wər ðə brıd3 ə'ut ət wudli did strə:Id

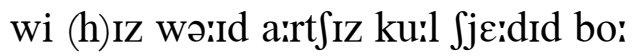

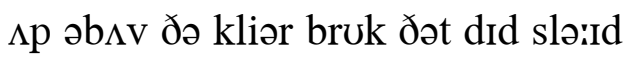

b(ə:)I ðə pppəlz bifo:md (h)wə:It əz sno:

az ðə gilkıps did kwivər əmpy

ðә (h)wə:It djeziz əspred in ə ji:t

ðər ə kwiktrıpən mæid kım əlpy

æI ə gə:rl wi (h)ər lə:Itstepən vi:t

ən Ji: krə:Id ə:I də præı Iz ðə ro:d

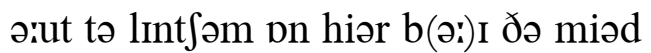

ən o: i:s ə:I mjed ع:nsər ən Jo:d

(h)ər ðə we: It wud tərrn ən wud liəd

gu: əlpy b(ə:)I ðə bi:t In ðə nuk

(h)wər ðə t t Ildərn də plæI In ðə kuil

tə ðə stepən stuənz э:vər ðə bruk

æI ðə gre: blpks ə rok ət ðə pu:l

ðદn jə do:nt si(:)m əba:rn ən əbred

ə:I spo:k $\Lambda \mathrm{p}$ ət ə pljes hiər əbə:ut

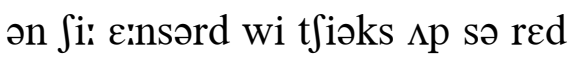

əz ə pə:Ini bət ljet əkım ə:ut

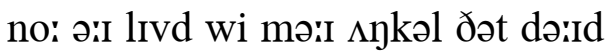

bak in jeprəl ən nə:u ə:Im əkım

hiər to ham to mə:I mıðər to bə:Id

æI tə (h)ər hə:us tə və:In(d) ə nju: huəm

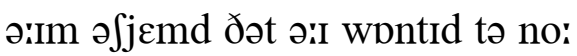

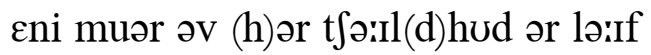

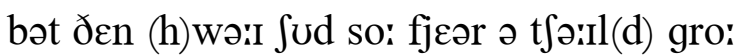

(h)wər nu: fe:ðər did bə:Id wi (h)Iz wə:If 
Then wi' blushes of zunrisèn morn,

She replied "that it midden be known,

Oh! they zent me awaÿ to be born,_-*

Aye, they hid me when zome would be shown."

Oh! it meäde me a'most teary-ey'd,

An' I vound I a'most could ha' groan'd-

What! so winnèn, an' still cast a-zide-

What! so lovely, an' not to be own'd;

Oh! a God-gift a-treated wi' scorn,

Oh! a child that a squier should own;

An' to zend her awaÿ to be born!-

Aye, to hide her where others be shown!

* Words once spoken to the writer. 


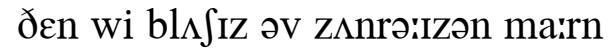

Si: riplə:Id ðat it midən bi: no:n

o: ðe: zent mi: əwə:I to bi: bairn

æI ðe: hId mi: (h)wen zım wud bi: Jo:n

o: It mjed mi: a:məst tiəriə:Id

ən ə:I və:un(d) ə:I a:məst kud hə gro:nd

(h)wpt so: winən ən strl ka:st əzə:Id

(h)wpt so: $1 \Lambda$ vli on not to bi: o:nd

o: a gpdgift atri:tid wi ska:rn

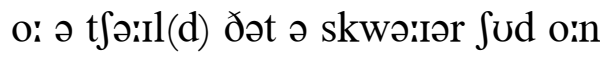

ən to $z \varepsilon n(d)(h) \partial r$ əwə:I to bi: ba:rn

æI to hə:Id (h)ər (h)wər $\Lambda$ ðrz bi: Jo:n 


\section{HAWTHORN DOWN}

AlL up the down's cool brow

I work'd in noontide's gleäre,

On where the slow-wheel'd plow

wagon

'D a-wore the grass half bare.

An' gil'cups quiver'd quick,

buttercups

As aïr did pass,

An' deäisies huddled thick

Among the grass.

The while my eärms did swing

arms

Wi' work I had on hand,

The quick-wing'd lark did zing

Above the green-tree'd land,

An' bwoys below me chafed

The dog vor fun,

An' he, vor all they laefd,

laughed

Did meäke em run.

The south zide o' the hill,

My own tun-smoke rose blue,-

chimney-

In North Coomb, near the mill,

My mother's wer in view-

Where woonce her vier vor all

once, fire

Ov us did burn,

As I have childern small

Round mine in turn.

An' zoo I still wull cheer

Her life wi' my small store,

As she do drop a tear

Bezide her lwonesome door. 
he:ða:rn də:un

a:l $\Lambda$ р ðə də:unz kuil brə:u

ə:I wə:rkt In nu:ntə:Idz gljeər

pn (h)wər ðə sle:u(h)willd plə:u

d əwuər ðə gra:s he:f bjeər

ən gilkıps kwivərd kwik

əz æIr did pa:s

ən djeziz hıdəld $\theta \mathrm{rk}$

әmpy ðə gra:s

ðə (h)wə:Il mə:ı ja:rmz did swin

wi wərrk ə:I had pn han(d)

ðə kwıkwınd la:rk did zIn

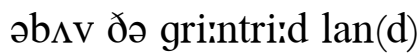

ən bwə:Iz bilo: mi: t $t \varepsilon: \mathrm{ft}$

ðə dpg vər f $\Lambda \mathrm{n}$

ən hi: vər a:l ðe: le:ft

did mjek əm r $\mathrm{n}$

ðə sə:u $\theta$ zə:Id ə ðə hIl

mə:I o:n tınsmo:k ro:z blu:

In np $\theta$ ku:m niər ðə mil

mə:I $\mathrm{m} \Lambda$ ðərz wər In vju:

(h)wər (w)u:ns (h)ər vəriər vər a:l

əv əs did bə:rn

əZ ə:I hav tfildərn sma:l

rə:un(d) mə:In in tə:rn

ən zu: ə:I strl wol tfior

(h)ər lə:If wi mə:I sma:l stuər

əz Ji: də drap ə tiər

bizə:Id (h)ər luənsəm duər 
The love that I do owe

Her ruf, I'll paÿ,

roof

An' then zit down below

My own wi' jaÿ.

joy 
ðə $1 \Lambda v$ ठət ə:I du: o:

(h)ər r $\Lambda$ f əsil pæI

ən ðعn zit də:un bilo:

mə:I o:n wi dzæI 


\section{OBEN VIELDS}

WeLL, you mid keep the town an' street,

may

Wi' grassless stwones to beät your veet,

An' zunless windows where your brows

Be never cooled by swaÿèn boughs;

An' let me end, as I begun,

My days in oben aïr an' zun,

Where zummer win's a-blowèn sweet,

Wi' blooth o' trees as white's a sheet;

blossom

Or swaÿèn boughs, a-bendèn low

Wi' rip'nèn apples in a row,

An' we a-risèn rathe do meet

early

The bright'nèn dawn wi' dewy veet,

An' leäve, at night, the vootless groves,

To rest 'ithin our thatchen oves.

eaves

An' here our childern still do bruise

The deäisy buds wi' tiny shoes,

As we did meet avore em, free

Vrom ceäre, in plaÿ below the tree.

An' there in me'th their lively eyes

mirth

Do glissen to the zunny skies,

As aïr do blow, wi' leäzy peäce

To cool, in sheäde, their burnèn feäce.

Where leaves o' spreadèn docks do hide

The zawpit's timber-lwoaded zide,

An' trees do lie, wi' scraggy limbs,

Among the deäisy's crimson rims.

An' they, so proud, wi' eärms a-spread

arms

To keep their balance good, do tread

Wi' ceäreful steps o' tiny zoles

The narrow zides o' trees an' poles. 
o:bən vi:l(d)z

wel jə mid ki(:)p ðə tə:un ən stri:t wi graislis stuənz to biət jər vi:t ən z^nlis windərz (h)wər jər brə:uz bi: nevər kuild b(ə:)I swæiən bə:uz ən let mi: $\varepsilon n(d)$ əz əII big $\Lambda n$ mə:I de:z in o:bən æIr ən zAn

(h)wər z^mər win(d)z əblo:ən swi:t

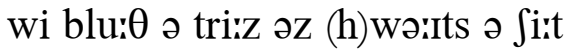
ar swæiən bə:uz əbendən lo: wi rə:Ipnən apəlz in ə ro: ən wi: ərə:Izən rjeð də mi:t ðə brə:itnən de:n wi djuii vi:t ən liəv ət nə:It ðə vutlis gro:vz tə rest IðIn ə:uər ðat〕ən o:vZ ən hiər ə:uər tfildərn strl də bru:z

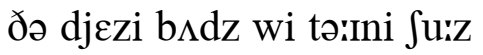
əz wi: did mi(:)t əvuər əm fri: vrəm kjeər in plæı bılo: ðə tri: ən ðər In me $\theta$ ðər lə:Ivli ə:Iz də glısən tə ðə zıni skə:Iz əz æIr də blo: wi ljezi pjes

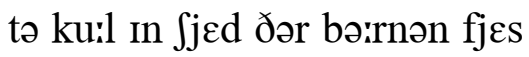
(h)wər li:vz ə spredən doks də hə:Id ðə zع:pits timbərluədıd zə:Id ən triz də lə:I wi skragi limz әmрy ðə djeziz krimzən rımz ən ðe: sə prə:ud wi ja:rmz əspred tə $\mathrm{ki}(:) \mathrm{p}$ ðər baləns gud də tred wi kjeərvul steps ə tə:Ini zo:lz ðə narə(r) zə:Idz ə tri:z ən po:lz 
An' zoo I'll leäve vor your light veet

The peävement o' the zunless street, While I do end, as I begun,

My days in oben aïr an' zun. 
ən zu: ə:Il liəv vər ju:r lə:It vi:t ðə pjevmənt ə ðə z^nlıs stri:t (h)wว:Il ə:I du: $\varepsilon$ (d) əZ ə:I big $\Lambda$ n mə:I de:z In o:bən æIr ən zın 


\section{WHAT JOHN WER A-TELLÈN HIS MIS'ESS}

AH! mam! you woonce come here the while

once

The zun, long years agoo, did shed

His het upon the wheat in hile,

heat, stook ${ }^{2}$

Wi' yollow hau'm an' ears o' red, stalk

Wi' little shoes too thin vor walks

Upon the scratchèn stubble-stalks;

You hardly reach'd wi' glossy head,

The vore wheel's top o' dousty red.

dusty

How time's a-vled! How years do vlee!

An' there you went an' zot inzide sat

A hile, in aïr a-streamèn cool,

As if 'ithin a room, vull wide

An' high, you zot to guide an' rule.

You leäz'd about the stubbly land, gleaned

An' soon vill'd up your small left hand

Wi' ruddy ears your right hand vound,

An' trail'd the stalks along the ground.

How time's a-gone! How years do goo!

Then in the waggon you did teäke

A ride, an' as the wheels vell down

Vrom ridge to vurrow, they did sheäke

On your small head your poppy crown,

An' now your little maïd, a dear,

Your childhood's very daps, is here,

Zoo let her stä̈, that her young feäce

Mid put a former year in pleäce.

How time do run! How years do roll!

\footnotetext{
${ }^{2}$ Hile: 'Ten sheaves of corn set up in the field, four on each side and one at each end, and forming a kind of roof (1844 Glossary).
} 
(h)wpt dzan wər ətદlən (h)Iz misis ə:ut In ðə kairn grə:un(d)

a: mam ju: (w)u:ns kım hiər ðə (h)wə:ıl ðə z^n lpy jiərz əgu: did $\int \varepsilon d$ (h)Iz het əppn ðə (h)wi:t In hə:Il wi jalər ha:m ən iərz ə red wi litəl Ju:z tu: ðın vər we:ks әppn ðə skratfən st $\Lambda$ bəlste:ks

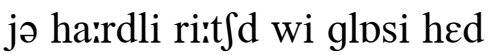
ðə vuər(h)willz tpp ə də:usti red hə:u tə:Imz əvled hə:u jiərz də vli:

ən ðər jə went ən zat Inzə:Id ə hə:Il In æIr əstri:mən ku:l əZ If IðIn ə ru:m vul wə:Id ən hə:I jə zat tə gə:Id ən ru:l jə liəzd əbə‘ut ðə st $\Lambda$ bli lan(d)

ən su:n vild $\Lambda p$ jər sma:l left han(d) wi rıdi iərz jər rə:It han(d) vərun(d) ən træild ðə ste:ks əlpy ðə grə:un(d) hə:u tə:Imz əgpn hə:u jiərz də gu:

ðعn In ðə wagən jə did tjek

ə rə:Id ən az ðə (h)willz vel də:un vrəm $\mathrm{r} \Lambda \mathrm{d} Z$ tə v $\Lambda$ rə ðe: did $\int j \varepsilon k$ pn jər sma:l hed jər pppi krə:un ən nə:u jər litəl mæid ə diər jər tfəill(d)hudz veri daps Iz hiər zu: let (h)ər stær dət (h)ər j $\wedge$ y fjes mid p $\Lambda \mathrm{t}$ ə fa:rmər jiər In pljes hə:u tə:Im də rın hə:u jiərz də ro:l 


\section{SHEÄDES}

Come here an' zit a while below

Theäse tower, grey and ivy-bound, this In sheäde, the while the zun do glow So hot upon the flow'ry ground; An' winds in flight, Do briskly smite

The blossoms bright, upon the gleäde, But never stir the sleepèn sheäde.

As when you stood upon the brink

O' yonder brook, wi' back-zunn'd head, Your zunny-grounded sheäde did zink shadow

Upon the water's grav'lly bed, Where weäves could zweep Away, or keep, The gravel heap that they'd a-meäde, But never wash awaÿ the sheäde.

An' zoo, when you can woonce vulvil so, once fulfil

What's feäir, a-tried by heaven's light, Why never fear that evil will

Can meäke a wrong o' your good right.

The right wull stand,

Vor all man's hand,

Till streams on zand, an' wind in gleädes, Can zweep awaÿ the zuncast sheädes. 
$\int j \varepsilon d z$

kım hiər ən zit ə (h)wə:I bilo:

ðiəs tə:uər gre: ən(d) ərivibə:un(d)

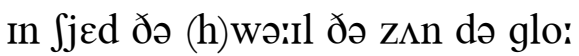

sə hpt əppn ðə flə:uri grə:un(d)

ən win(d)z in fla:it

də briskli smə:It

ðə blpsəmz brə:It əppn ðə gljed

bət nevər stə:r ðə sli:pən $\int j \varepsilon d$

az (h)wen ju: stud əppn ðə brink

ə jandər bruk wi bakzınd hed

jər zınigrə:undid Sjed did zink

əppn ðə wə:tərz gravli bed

(h)wər wjevz kud zwi:p

әพə:I ar ki(:)p

ðə gravəl hi:p ðət ðe:d əmjed

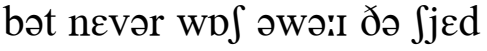

ən zu: (h)wen ju: kən (w)u:ns vulvil

(h)wpts fjeər ətrə:Id b(əi)I hevənz lə:It

(h)wə:I nevər fiər ðət iivəl wil

kən mjek ə roy ə ju:r gud rə:It

ðə rə:It wul stan(d)

vər a:l manz han(d)

trl stri:mz pn zan(d) ən win(d) In gljedz

kən zwi:p әwə:ı ðə z^nka:st $\int j \varepsilon d z$ 
HERE did swäy the eltrot flow'rs, cow-parsley

When the hours o' night wer vew, An' the zun, wi' eärly beams

Brighten'd streams, an' dried the dew, An' the goocoo there did greet

Passers by wi' dousty veet. cuckoo dusty

There the milkmaïd hung her brow

By the cow, a-sheenèn red;

An' the dog, wi' upward looks,

Watch'd the rooks above his head,

An' the brook, vrom bow to bow, bend

Here went swift, an' there wer slow.

Now the cwolder-blowèn blast,

Here do cast vrom elems' heads

Feäded leaves, a-whirlèn round,

Down to ground, in yollow beds,

Ruslèn under milkers' shoes,

When the day do dry the dews.

Soon shall grass, a-vrosted bright,

Glisten white instead o' green, An' the wind shall smite the cows,

Where the boughs be now their screen.

Things do change as years do vlee;

What ha' years in store vor me? 
tə:Imz ə jiər

hiər did swæi ði عltrpt flə:uərz

(h)wen ði ə'uərz ə nəit wər vju:

ən ठə zムn wi jərrli bi:mz

brə:Itənd stri:mz ən drə:Id ðə dju:

ən ðə guku: ðər did griit

paisərz bə:I wi də:usti viit

ðər ðə mılkmæId hıy (h)ər brə:u

b(ə:)I ðə kə'u ə९i:nən red

ən ðə dpg wi $\Lambda$ pərd luks

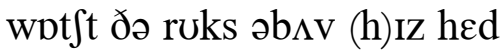

ən ठə bruk vrəm bo: to bo:

hiər went swift ən ðعər wər slo:

nə:u ðə kuəldərblo:ən blaist

hiər də kaist vrəm عləmz hedz

fjedıd li:vz ə(h)wərr(d)lən rərun(d)

də:un to grə:un(d) in jalər bedz

r $\Lambda$ slən $\Lambda$ ndər milkərz Ju:z

(h)wen ðə de: də drə:I ðə dju:z

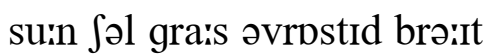

glisən (h)wə:It insted ə gri:n

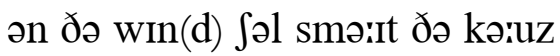

(h)wər ðə bə:uz bi: nə:u ðər skri:n

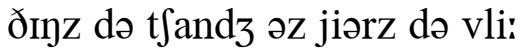

(h)wpt ha jiərz in stuər vər mi: 
ECLOGUE

RACKETÈN JOE

Racketèn Joe; his Sister; his Cousin Fanny; and the Dog

RACKETÈN JOE

HEIGH! heigh! here. Who's about?

HIS SISTER

Oh! lauk! Here's Joe, a rantèn lout,

Lord

A-meäkèn his wild randy-rout.

racket

RACKETÈN JOE

Heigh! Fanny! How d'ye do? (slaps her.)

\section{FANNY}

Oh! fie; why all the woo'se vor you

worse

A-slappèn o’ me, black an’ blue,

My back!

HIS SISTER

A whack! you loose-eärm'd chap,

-armed

To gi'e your cousin sich a slap!

give

\section{FANNY}

I'll pull the heäir o'n, I do vow;

his hair

HIS SISTER

I'll pull the ears o'n. There.

THE DOG

Wowh! wow! 
$\varepsilon k \operatorname{lng}$

rakətən dzo:

rakətən dzo: (h)Iz sistər (h)Iz kızən fani ən(d) ðə dpg

RACKETÈN JOE

hæI hæI hiər hu:z əbə:ut

HIS SISTER

o: lo:k hiorz dzo: ə re:ntən ləuut

əmjekən (h)Iz wə:Il(d) randirə:ut

RACKETÈN JOE

hæI fani hə:u dji: du: (slaps her.)

FANNY

o: fə:I (h)wə:ı a:l ðə wu:s vər ju:

əslapən ə mi: blak ən blu:

mə:I bak

HIS SISTER

ə (h)wak jə lussja:rmd t fap

to gi: jər kızən sit ə slap

FANNY

ə:Il pul ðə hjeər o:n ə:I də və:u

HIS SISTER

ə:Il pul ði iərz o:n ðعər

THE DOG

พว:น พว:น 


\section{FANNY}

A-comèn up the drong,

How he did smack his leather thong,

A-zingèn, as he thought, a zong;

\section{HIS SISTER}

An' there the pigs did scote

race

Azide, in fright, wi' squeakèn droat,

Wi' geese a pitchèn up a note.

Look there.

\section{FANNY}

His chair!

\section{HIS SISTER}

He thump'd en down,

As if he'd het en into ground.

RACKETÈN JOE

Heigh! heigh! Look here! the vier is out.

HIS SISTER

How he do knock the tongs about!

\section{FANNY}

Now theäre's his whip-nob, plum

Upon the teäble vor a drum;

\section{HIS SISTER}

An' there's a dent so big's your thumb. 
FANNY

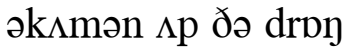

hə:u hi: did smak (h)Iz leðər ðpך

əzIngən əz hi: ơ:t ə zDク

HIS SISTER

ən ðər ðə pigz did skə:ut

əzə:Id in frə:It wi skwi:kən dro:t

wi girs $ә$ pitfon $\Lambda$ p ə no:t

luk ðعər

FANNY

$$
\text { (h) IZ t } \int \varepsilon \partial r
$$

HIS SISTER

$$
\text { ə } \theta \text { nmpt ən də:un }
$$

əZ If əd het ən Intə grə:un(d)

RACKETÈN JOE

hæı hæı luk hiər ðə və:ıər Iz ə:ut

HIS SISTER

hə:u hi: də nok ðə tonz əbə:ut

FANNY

nə:u ðعərz (h)IZ (h)wıpnob plım

әppn ðə tjebəl vər ə $\mathrm{dr} \Lambda \mathrm{m}$

HIS SISTER

ən ðərz ə dent sə bigz jər ð $\Lambda \mathrm{m}$ 
RACKETÈN JOE

My hat's awore so quaer.

HIS SISTER

'Tis quaer enough, but not wi' wear;

But dabs an' dashes he do bear.

knocks and blows it receives

RACKETÈN JOE

The zow!

HIS SISTER

$$
\text { What now? }
$$

\section{RACKETÈN JOE}

She's in the plot.

A-routèn up the flower knot.

bed

Ho! Towzer! Here, rout out the zow,

Heigh! here, hie at her. Tiss!

THE DOG

$$
\text { Wowh! wow! }
$$

\section{HIS SISTER}

How he do rant and roar,

An' stump an' stamp about the vloor,

An' swing, an' slap, an' slam the door!

He don't put down a thing,

But he do dab, an' dash, an' ding

thump and throw and smash

It down, till all the house do ring. 
RACKETÈN JOE

mə:I hats əwuər sə kweər

HIS SISTER

tIz kweər in $\Lambda$ f bət not wi weər

bət dabz ən dafiz hi: də beər

RACKETÈN JOE

ðә zə:u

HIS SISTER

(h)wpt nə:u

RACKETÈN JOE

Jiız In ðə plpt

ərə:utən $\Lambda$ д ðə flə:uər npt

ho: tə:uzər hiər rə:ut ə:ut ðə zə:u

hæi hiər hə:I at hər tIs

THE DOG

พว:u wว:u

HIS SISTER

hə:u ə də rant ən(d) ruər

ən st $\Lambda \mathrm{mp}$ ən stamp əbə'ut ðə vluər

ən swin ən slap ən slam ðə duər

ə do:nt p $\Lambda \mathrm{t}$ də:un ə ðı门

bət $ə$ də dab ən das ən din

It də:un trl a:l ðə hə‘us də rın 
RACKETÈN JOE

She's out.

FANNY

Noo doubt.

HIS SISTER

Athirt the bank, across

Look! how the dog an' he do pank.

\section{FANNY}

Staÿ out, an' heed her now an' then,

To zee she don't come in ageän. 
RACKETÈN JOE

fi:z ərut

FANNY

nu: dərut

HIS SISTER

əðə:rt ðə bayk

luk hə'u ðə dpg ən hi: də payk

FANNY

stæI ə:ut ən hi:d (h)ər nə:u ən ðعn

to zi: $\int i:$ do:nt kım in əgjen 
WHEN I led by zummer streams

The pride o' Lea, as naïghbours thought her, While the zun, wi' evenèn beams,

Did cast our sheädes athirt the water; shadows across

Winds a-blowèn,

Streams a-flowèn,

Skies a-glowèn,

Tokens ov my jaÿ zoo fleetèn,

joy so

Heighten'd it, that happy meetèn.

Then, when maïd an' man took pleäces,

Gaÿ in winter's Chris'mas dances,

Showèn in their merry feäces

Kindly smiles an' glisnèn glances;

Stars a-winkèn,

Day a-shrinkèn,

Sheädes a-zinkèn,

Brought anew the happy meetèn,

That did meäke the night too fleetèn. 
(h)wen ə:I led b(ə:)I z^mər stri:mz

ðə prə:Id ə li: əz næibərz ðo:t hər

(h)wə:Il ðə z^n wi i:vmən bi:mz

dıd kaist ə:uər $\int j \varepsilon d z$ əðə:rt ðə wə:tər

win (d)z əblo:ən

stri:mz əflo:ən

skə:Iz əglo:ən

to:kənz əv mə:I dzæi zu: flistən

hə:itənd It ðat hapi mi:tən

ðعn (h)wen mæid ən man tuk pljesız

gæi in wintərz krisməs de:nsız

Jo:ən In ðər meri fjesız

kə:In(d)li smə:Ilz ən glisnən gle:nsız

sta:rz əwinkən

de: $2 \int r i n k ə n$

jjedz əzinkən

bro:t ənju: ðə hapi mi:tən

ðət did mjek ðə nə:It tu: fli:tən 
TO ME

AT night, as drough the meäd I took my waÿ, through

In aïr a-sweeten'd by the new-meäde haÿ,

A stream a-vallèn down a rock did sound,

Though out o' zight wer foam an' stwone to me.

Behind the knap, above the gloomy copse, billock

The wind did russle in the trees' high tops,

Though evenèn darkness, an' the risèn hill,

Kept all the quiv'rèn leaves unshown to me.

Within the copse, below the zunless sky,

I heärd a nightèngeäle, a-warblèn high

Her lwoansome zong, a-hidden vrom my zight,

An' showèn nothèn but her mwoan to me.

An' by a house, where rwoses hung avore

The thatch-brow'd window, an' the oben door,

I heärd the merry words, an' hearty laugh

O’ zome feäir maïd, as eet unknown to me.

High over head the white-rimm'd clouds went on,

Wi' woone a-comèn up, vor woone a-gone;

one

An' feäir they floated in their sky-back'd flight,

But still they never meäde a sound to me.

An' there the miller, down the stream did float

Wi' all his childern, in his white-sail'd bwoat,

Vur off, beyond the stragglèn cows in meäd,

But zent noo vaïce, athirt the ground, to me.

far

across

butterfly

fire- 
to $\mathrm{mi}:$

at nə:It əz dru: ðə miəd ə:I tuk mə:I wæI In æIr əswiitənd b(ə:)I ðə nju:mjєd hæı ə stri:m əvailən də:un ə rok did sə:un(d) ðо: ə:ut ə zə:It wər fo:m ən stuən tə mi:

bihə:In(d) ðə nap əbıv ðə glu:mi kpps ðə win(d) did r $\Lambda$ səl In ðə tri:z hə:I tpps ðо: i:vmən darrknis ən ðə rə:ızən hil kept a:l ðə kwıvrən liivz $\Lambda$ n Jo:n tə mi:

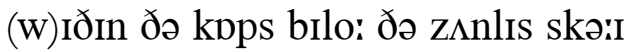
ə:I hiərd ə nə:Itəngjel əwa:rblən hə:I (h)ər luənsəm zpy əhIdən vrəm mə:I zə:It

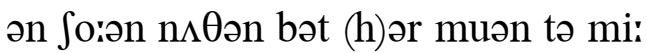

ən b(ə:)I ə hə:us (h)wər ruəzIz hıy əvuər ðə ðat $\int b r ə: u d$ windər ən ði o:bən duər ә:I hiərd ðə mعri wə:rdz ən ha:rti le:f

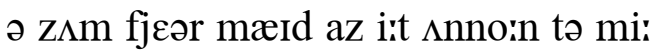

hə:I ว:vər hed ðə (h)wə:Itrimd klə:udz went pn wi (w)uin əkımən $\Lambda$ p vər (w)uin əgpn ən fjeər ðе: flo:tıd in ðər skə:ıbakt flə:ıt bət stıl ðe: nevər mjed ə sə:un(d) tə mi:

ən ðər ðə milər də:un ðə stri:m did flo:t wi a:l (h)Iz t flldərn in (h)Iz (h)wə:Itsæild b(w)uət və:r pf bijand ðə straglən kə:uz in miəd bət zent nu: væIs əðə:rt ðə grə:un(d) tə mi:

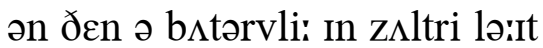
ə(h)willən pn əbə:ut mi: və:Iərbrə:It 
Did show the gaÿest colors to my eye,

But still did bring noo vaïce around to me.

I met the merry laugher on the down,

Bezide her mother, on the path to town,

An' oh! her sheäpe wer comely to the zight,

But wordless then wer she a-vound to me.

Zoo, sweet ov unzeen things mid be the sound,

An' feäir to zight mid soundless things be vound,

But I've the laugh to hear, an' feäce to zee,

Vor they be now my own, a-bound to me. 


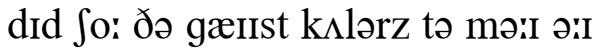

bət stıl did brin nu: væIs ərə:un(d) tə mi:

ə:I met ðə meri le:fər pn ðə də:un

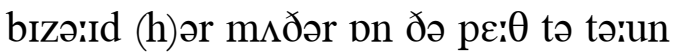

ən o: (h)ər Jjep wər kımli tə ðə zə:It

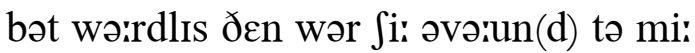

zu: swi(:)t əv nnzi:n ðınz mid bi: ðe sə:un(d)

ən fjeər to zə:It mid sə:un(d)les ðinz bi: və:un(d)

bət ə:IV ðə le:f tə hiər ən fjes tə zi:

vər ðe: bi: nə:u mə:I o:n əbə:un(d) tə mi: 
TWO AN' TWO

THE zun, O Jessie, while his feäce do rise

In vi'ry skies, a-sheddèn out his light

fiery

On yollow corn a-weävèn down below

His yollow glow, is gaÿ avore the zight.

By two an' two,

How goodly things do goo,

A-matchèn woone another to fulvill

one

The goodness ov their Meäkèr's will.

How bright the spreadèn water in the lew

shelter

Do catch the blue, a-sheenèn vrom the sky;

shining

How true the grass do teäke the dewy bead

That it do need, while dousty roads be dry.

dusty

By peäir an' peäir

Each thing's a-meäde to sheäre

share

The good another can bestow,

In wisdom's work down here below.

The lowest lim's o' trees do seldom grow

A-spread too low to gi'e the cows a sheäde;

give

The air's to bear the bird, the bird's to rise;

Vor light the eyes, vor eyes the light's a-meäde.

'Tis gi'e an' teäke,

An' woone vor others' seäke;

In peäirs a-workèn out their ends,

Though men be foes that should be friends. 
tu: on tu:

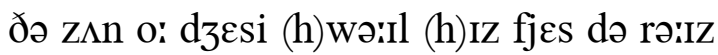

In və:Iəri skə:Iz ə $\int \varepsilon d \partial n$ ə:ut (h)Iz lə:It

pn jalər ka:rn əwjevən də:un bilo:

(h)Iz jalər glo: Iz gæı əvuər ðə zə:It

b(ว:) I tu: on tu:

hə:u gudli ðınz də gu:

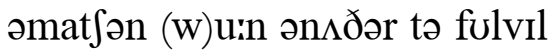

ðə gudnis əv ðər mjદkərz wil

hə:u brə:It ðə spredən wə:tər in ðə lu:

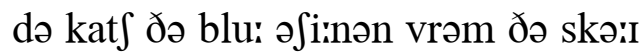

hə:u tru: ðə gra:s də tjek ðə djuii bi:d

ðət It də ni:d (h)wə:Il də:usti ro:dz bi: drə:I

b(ə:)I pjeər ən pjeər

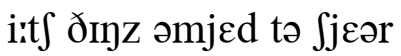

ðə gud ən^ðər kən bisto:

In wisdəmz wərrk də:un hiər bilo:

ðə lo:ist limz ə tri:z də seldəm gro:

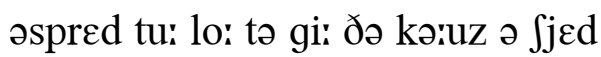

ði æIrz tə beər ðə bə:rd ðə bə:rdz tə rə:Iz

vər lə:It ði ə:Iz vər ə:Iz ðə lə:Its əmjed

tIz gi: on tjek

ən (w)uin vər $\Lambda$ ðərz sjek

In pjeərz əwə:rkən ə:ut ðər $\varepsilon \mathrm{n}(\mathrm{d}) \mathrm{z}$

ðo: men bi: fo:z ðət Jud bi: $\operatorname{fr\varepsilon n}(\mathrm{d}) \mathrm{z}$ 
AT eventide the wind wer loud

By trees an' tuns above woone's head, cbimneys, one's

An' all the sky wer woone dark cloud,

Vor all it had noo rain to shed;

An' as the darkness gather'd thick,

I zot me down below a rick, sat

Where straws upon the win' did ride

Wi' giddy flights, along my zide,

Though unmolestèn me a-restèn,

Where I laÿ'ithin the lew.

My wife's bright vier indoors did cast

Its fleäme upon the window peänes

That screen'd her teäble, while the blast

Vled on in music down the leänes; flew

An' as I zot in vaïceless thought

Ov other zummer-tides, that brought

The sheenèn grass below the lark,

Or left their ricks a-wearèn dark,

My childern voun' me, an' come roun' me, found

Where I laÿ' 'ithin the lew.

The rick that then did keep me lew sheltered

Would be a-gone another Fall, An' I, in zome years, in a vew,

Mid leäve the childern, big or small;

But He that meäde the wind, an' meäde

The lewth, an' zent wi' het the sheäde,

Can keep my childern, all alwone

Or under me, an' though vull grown

Or little lispers, wi' their whispers,

There a-lyèn in the lew. 
ðə lu: ə ðə rik

ət i:vəntə:Id ðə win(d) wər lə:ud

b(ว:)I tri:z ən t $\Lambda n z$ əb $\Lambda v$ (w)u:nz hed

ən a:l ðə skə:I wər (w)u:n da:rk klə:ud

vər ail it had nu: ræin to $\int \varepsilon d$

ən az ðə da:rknıs gaðərd $\theta \mathrm{rk}$

ə:I zat mi: dərun bilo: ə rik

(h)wər stre:z əppn ðə win(d) did rə:Id

wi gidi flə:Its əlpy mə:I zə:Id

ðo: $\Lambda$ nməlestən mi: ərestən

(h)wər ə:ı læı ıðın ðə lu:

mə:I wə:Ifs brə:It və:ıər Induərz did kaist

Its fljem əppn ðə windər pjenz

ðət skri:nd (h)ər tjebəl (h)wə:Il ðə bla:st

vled pn in mjuizık də:un ðə ljenz

ən az ə:I zat In væIslis ðว:t

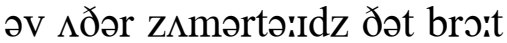

ðə Siinən gra:s bilo: ðə la:rk

ar left ðər riks əwعərən da:rk

mə:I t t Ildərn vərun(d) mi: ən $\mathrm{k} \Lambda \mathrm{m}$ rə:un mi:

(h)wər ə:ı læı ıðın ðə lu:

ðə rık ðət ðعn did ki(:)p mi: lu:

wud bi: əgpn ən^ðər fa:l

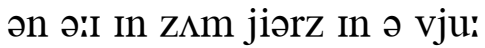

mid liəv ðə tfildərn big ər sma:l

bət hi: ðət mjed ðə wIn(d) ən mjed

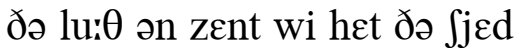

kən ki(:)p mə:I t fildərn a:l əluən

ər $\Lambda$ ndər mi: ən ðo: vol grə:un

ar litəl lispərz wi ðər (h)wispərz

ðər ələ:ıən In ðə lu: 
THERE lovely Jenny past, While the blast did blow

On over Ashknowle Hill

To the mill below;

A-blinkèn quick, wi' lashes long,

Above her cheäks o' red,

Ageän the wind, a-beätèn strong,

Upon her droopèn head.

Oh! let dry win' blow bleäk,

On her cheäk so heäle,

bale

But let noo raïn-shot chill

Meäke her ill an' peäle;

Vor healthy is the breath the blast

Upon the hill do yield,

An' healthy is the light a cast

Vrom lofty sky to vield.

An' mid noo sorrow-pang

may

Ever hang a tear

Upon the dark lash-heäir

Ov my feäirest dear;

An' mid noo unkind deed o' mine

Spweil what my love mid gaïn,

Nor meäke my merry Jenny pine

At last wi' dim-ey'd païn. 
ðə win(d) In (w)u:nz fjes

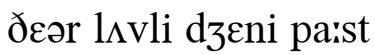

(h)wə:il ðə bla:st did blo:

pn oivor afno:l hil

tə ðə mil bilo:

əblınkən kwık wi lasız lon

əb $\Lambda \mathrm{v}$ (h)ər tfiəks ə red

əgjen ðə wIn(d) əbiətən stroy

əppn (h)ər dru:pən hed

o: let drə:I win(d) blo: bliək

pn (h)ər t fiək sə hjel

bət let nu: ræIn $\int \mathrm{pt} \mathrm{t} \int \mathrm{Il}$

mjek (h)ər Il ən pjel

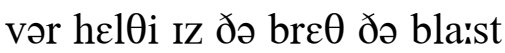

əppn ðə hıl də jill(d)

ən helӨi iz ðə lə:ıt əka:st

vrəm lpfti skə:I tə vi:l(d)

ən mid nu: sarə(r)pay

Evər hay ə tiər

əppn ðə da:rk laShjeər

əv mə:I fjeərəst diər

ən mid nu: $\Lambda$ nkə:In(d) diid ə mə:In

spwə:Il (h)wpt mə:I $1 \Lambda \mathrm{v}$ mid gæin

nar mjek mə:I meri dzzni pə:In

ot le:st wi dimə:Id pæin 


\section{TOKENS}

GREEN mwold on zummer bars do show

That they've a-dripp'd in Winter wet;

The hoof-worn ring o' groun' below

The tree, do tell o' storms or het;

The trees in rank along a ledge

Do show where woonce did bloom a hedge;

once

An' where the vurrow-marks do stripe

The down, the wheat woonce rustled ripe.

Each mark ov things a-gone vrom view-

To eyezight's woone, to soulzight two.

The grass ageän the mwoldrèn door

'S a tóken sad o' vo'k a-gone,

An' where the house, bwoth wall an' vloor,

'S a-lost, the well mid linger on.

What tokens, then, could Meäry gi'e

That she'd a-liv'd, an' liv'd vor me,

But things a-done vor thought an' view?

Good things that nwone ageän can do,

An' every work her love ha' wrought,

To eyezight's woone, but two to thought. 
to:kənz

gri:n muəld pn zımər ba:rz də Jo:

ðət ðe:v ədript in wintər wet

ðə h^fwa:rn rin ə grə:un bilo:

ðə tri: də tel ə sta:rmz ər het

ðə tri:z In rapk əlpy ə led3

də So: (h)wər (w)unns did blu:m ə hed3

ən (h)wər ðə v $\Lambda$ rəma:rks də strə:ıр

ðə də:un ðə (h)wi:t (w)uns rısəld rə:Ip

iit mark əv ðınz əgnn vrəm vju:

tu ə:Izə:Its (w)u:n to so:lzə:It tu:

ðə gra:s əgjєn ðə muəldrən duər

z ə to:kən sad ə vo:k əgpn

ən (h)wər ðə hə:us buəð wa:l ən vluər

z əlpst ðə wel mid lingər pn

(h)wpt to:kənz ðen kud mjeəri gi:

ðət $\int i$ i:d əlivd ən livd vər mi:

bət ðıyz əd $\Lambda$ n vər ðo:t ən vju:

gud ðınz ðət nuən əgjen kən du:

ən عvri wərrk (h)ər $1 \Lambda \mathrm{v}$ hə ro:t

tu ə:Izə:Its (w)u:n bət tu: tə ðっ:t 
THE rick ov our last zummer's haulèn

Now vrom grey's a-feäded dark, An' off the barken rail's a-vallèn,

Day by day, the rottèn bark.-

But short's the time our works do stand, So feäir's we put em out ov hand.

Vor time a-passèn, wet an' dry,

Do spweil em wi' his changèn sky,

The while wi' strivèn hope, we men,

Though a-ruèn time's undoèn,

Still do tweil an' tweil ageän.

In wall-zide sheädes, by leafy bowers,

Underneath the swaÿèn tree,

O' leäte, as round the bloomèn flowers,

Lowly humm'd the giddy bee,

My childern's small left voot did smite

Their tiny speäde, the while the right

Did trample on a deäisy head,

Bezide the flower's dousty bed,

An' though their work wer idle then,

They a-smilèn, an' a-tweilèn,

Still did work an' work ageän.

Now their little limbs be stronger,

Deeper now their vaïce do sound;

An' their little veet be longer,

An' do tread on other ground;

An' rust is on the little bleädes

Ov all the broken-hafted speädes,

An' flow'rs that wer my hope an' pride

Ha' long agoo a-bloom'd an' died, 
twว:Il

ðə rik əv ə:uər le:st zımərz ha:lən

nə:u vrəm gre:z əfjedid da:rk

ən pf ðə ba:rkən ræilz əva:lən

de: b(ə:)I de: ðə rotən ba:rk

bət Ja:rts ठə tə:Im ə:uər wə:rks də $\operatorname{stan}(\mathrm{d})$

sə fjeərz wi: p $\Lambda$ t əm ərut əv han(d)

vər tə:Im əpa:sən wet ən drə:I

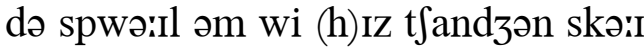

ðə (h)wə:Il wi strə:Ivən ho:p wi: men

ðо: əru:ən tə:Imz $\Lambda$ ndu:ən

strl də twəril ən twəiıl əgjen

In wa:lzə:Id $\int j \varepsilon d z$ b(ə:)I li:fi bə:uərz

$\Lambda$ ndərne: $\theta$ ðə swæıən tri:

ə ljet əz rə:un(d) ðə blu:mən flə:uərz

lo:li h^md ðə gidi bi:

mə:I t IIldərnz sma:l left vut did sməit

ðər tə:Ini spjed ðə (h)wə:Il ðə rə:It

did trampəl pn ə djezi hed

bızə:Id ðə flə:uərz də:usti bed

ən ðo: ðər wərrk wər ə:Idəl ðعn

ðе: əsmə:Ilən ən ətwə:Ilən

strl did wə:rk ən wərrk əgjen

nə:u ðər litəl limz bi: strpygər

di:pər nə:u ðər væIs də sə:un(d)

ən ðər litəl vi:t bi: longər

ən də tred pn $\Lambda$ ð๐ grə氵un(d)

ən r $\Lambda$ st Iz pn ðə litəl bljedz

əv a:l ðə bro:kənhe:ftId spjedz

ən flə:uərz ðət wər mə:I ho:p ən prə:Id

hə lpy əgu: əblu:md ən də:Id 
But still as I did leäbor then

Vor love ov all them childern small,

Zoo now I'll tweil an' tweil ageän.

When the smokeless tun's a-growèn

chimney's

Cwold as dew below the stars,

An' when the vier noo mwore's a-glowèn

fire

Red between the window bars,

We then do laÿ our weary heads

In peace upon their nightly beds,

An' gi'e woone sock, wi' heavèn breast,

give one sigh

An' then breathe soft the breath o' rest,

Till day do call the sons o' men

Vrom night-sleep's blackness, vull o' sprackness,

energy

Out abroad to tweil ageän.

Where the vaïce o' the winds is mildest,

In the plain, their stroke is keen;

Where their dreatnèn vaïce is wildest,

threatening

In the grove, the grove's our screen.

An' where the worold in their strife

Do dreatèn mwost our tweilsome life,

Why there Almighty ceäre mid cast

may

A better screen ageän the blast.

Zoo I woon't live in fear o' men,

so

But, man-neglected, God-directed,

Still wull tweil an' tweil ageän. 
bət stıl əZ ə:I did ljebər ðعn

vər $1 \Lambda \mathrm{v}$ əv a:l ðعm t fildərn sma:l

zu: nə:u ə:Il twə:ıl ən twə:Il əgjen

(h)wعn ðə smo:klis t^nz əgro:ən

kuəld əz dju: bilo: ðə sta:rz

ən (h)wen ðə və:ıər nu: muərz əglo:ən

red bitwi:n ðә windər ba:rz

wi: ðعn də le: ə:uər wiəri hedz

In pi:s əppn ðər nə:ttli bedz

ən gi: (w)uin spk wi hi:vən brest

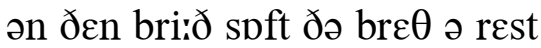

tıl de: də ka:l ðə sınz ə men

vrəm nə:Itsli:ps blaknəs vol ə spraknis

ə:ut əbro:d to twə:ıl əgjen

(h)wər ðə væIs ə ðə win(d)Z IZ mə:Ildist

In ðə plæIn ðər stro:k Iz ki:n

(h)wər ठər dretnən væIs IZ wə:Ildist

In ðə gro:v ðə gro:vz ə:uər skri:n

ən (h)wər ðə wə:rdəl in ðər strə:If

də dretən muəst ə:uər twə:Ilsəm lə:If

(h)wə:I ðعər a:lmə:Iti kjeər mId kaist

ə betər skriin əgjen ðə bla:st

zu: ə:I wu(:)nt liv In fiər ə men

bət man niglektıd god dərektıd

stıl wol twə:ıl ən twə:il əgjen 
FANCY

IN stillness we ha' words to hear,

An' sheäpes to zee in darkest night,

An' tongues a-lost can hail us near,

An' souls a-gone can smile in zight;

When Fancy now do wander back

To years a-spent, an' bring to mind

Zome happy tide a-left behind

In weästèn life's slow-beätèn track.

wasting

When feädèn leaves do drip wi' raïn,

fading

Our thoughts can ramble in the dry;

When Winter win' do zweep the plain

We still can have a zunny sky.

Vor though our limbs be winter-wrung,

We still can zee, wi' Fancy's eyes,

The brightest looks ov e'th an' skies,

earth

That we did know when we wer young.

In païn our thoughts can pass to eäse,

In work our souls can be at plaÿ,

An' leäve behind the chilly leäse

meadow

Vor warm-aïr'd meäds o' new mow'd haÿ,

When we do vlee in Fancy's flight

Vrom daily ills avore our feäce,

An' linger in zome happy pleäce

Ov me'th an' smiles, an' warmth an' light.

mirth 
fansi

In stilnis wi: ha wə:rdz to hiər ən $\int j \varepsilon p s$ to zi: in da:rkist nə:It ən t $\Lambda$ z əlpst kən hæil əs niər ən so:lz əgin kən smə:Il in zə:It (h)wen fansi nə:u də wondər bak tə jiərz əspent ən brin to mə:In(d) zムm hapi tə:Id əleft bihə:In(d) In wjestən ləiffs slo:biətən trak

(h)wen fjedən liivz də drıp wi ræIn ə:uər ðっ:ts kən rambəl in ðə drə:I (h)wen wintər win(d) də zwi:p ðə plæın wi: stıl kən hav ə zムni skə:I var ठo: ə:uər limz bi: wintər r $\wedge$ y wi: stıl kən zi: wi fansiz ə:IZ ðə brə:ItIst luks əv $\varepsilon \theta$ ən skə:IZ ðət wi: did no: (h)wen wi: wər j $\Lambda$ y

In pæIn əruər ðっ:ts kən pais tu iəz In wərrk ə:uər so:lz kən bi: ət plæI ən liəv bihə:In(d) ðə t fıli liəz vər wa:rmærrd miədz ə nju: mo:d hæI (h)wen wi: də vli: in fansiz flə:It vrəm de:li ilz əvuər ə:uər fjes ən lingər in z $\mathrm{m}$ hapi pljes əv $\operatorname{m\varepsilon } \theta$ ən smərilz ən wa:rm $\theta$ ən lə:It 
NEWS o' grief had overteäken

Dark-ey'd Fanny, now vorseäken;

There she zot, wi' breast a-heavèn, sat

While vrom zide to zide, wi'grievèn,

Vell her head, wi' tears a-creepèn

Down her cheäks, in bitter weepèn.

There wer still the ribbon-bow

She tied avore her hour ov woe,

An' there wer still the han's that tied it

Hangèn white,

Or wringèn tight,

In ceäre that drown'd all ceäre bezide it.

When a man, wi'heartless slightèn,

Mid become a maïden's blightèn,

He mid ceärlessly vorseäke her,

But must answer to her Meäker;

He mid slight, wi' selfish blindness,

All her deeds o' lovèn-kindness,

God wull waïgh em wi' the slightèn

That mid be her love's requitèn;

He do look on each deceiver,

He do know

What weight o' woe

Do breäk the heart ov ev'ry griever. 
ðə bro:kən ha:rt

nju:z ə gri:f had o:vərtjekən da:rkə:Id fani nə:u varsjekən ðər Si: zat wi brest əhi:vən (h)wə:il vrəm zə:Id to zə:Id wi griivən vel (h)ər hed wi tiərz əkri:pən də:un (h)ər t fiəks in bitər wi:pən ðər wər stıl ðə ribənbo: Si: tə:Id əvuər (h)ər ə:uər əv wo: ən ðər wər stıl ðə hanz ðət tə:Id It hayən (h)wərit ar ringən təit

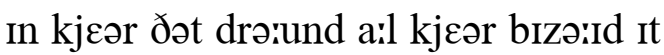

(h)wen ə man wi ha:rtlis slə:itən mid bikım ə mæIdənz blə:itən hi: mid kjeərlısli varsjek hər

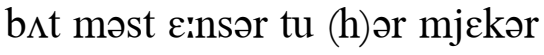
hi: mid slə:it wi selfi blə:In(d)nis

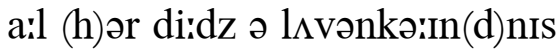
gpd wul wæi əm wi ðə sləittən ठət mid bi: (h)ər $1 \Lambda \mathrm{vz}$ rikwə:Itən hi: də luk pn iit disiivər hi: do no: (h)wDt wæit ə wo:

də bre:k ðə ha:rt əv عvri griivər 


\section{EVENÈN LIGHT}

THE while I took my bit o’ rest,

Below my house's eastern sheäde,

The things that stood in vield an' gleäde

Wer bright in zunsheen vrom the west.

sunshine

There bright wer east-ward mound an' wall,

An' bright wer trees, arisèn tall,

An' bright did break 'ithin the brook,

Down rocks, the watervall.

There deep 'ithin my pworches bow

arch

Did hang my heavy woaken door,

An' in beyond en, on the vloor,

oak

it

The evenèn dusk did gather slow;

But bright did gleäre the twinklèn spwokes

O' runnèn carriage wheels, as vo'ks

Out east did ride along the road,

Bezide the low-bough'd woaks,

oaks

An' I'd a-lost the zun vrom view,

Until ageän his feäce mid rise, might

A-sheenèn vrom the eastern skies

shining

To brighten up the rwose-borne dew;

But still his lingrèn light did gi'e

give

My heart a touchèn jaÿ, to zee

joy

His beams a-shed, wi' stratchèn sheäde,

On east-ward wall an' tree.

When jaÿ, a-zent me vrom above,

Vrom my sad heart is now agone,

An' others be a-walkèn on,

Amid the light ov Heavèn's love, 
i:vmən lə:it

ðə (h)wə:Il ə:I tuk mə:I bit ə rest bılo: mə:I hərusız isstərn $\int j \varepsilon d$

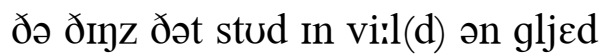

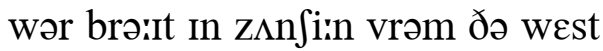
ðər brə:It wər isstwərd məiun(d) ən wa:l ən brə:It wər tri:z ərə:Izən ta:l ən brə:It did bre:k Iðın ðə bruk də:un roks ðə wə:tərva:l

ðər di:p ıðın mə:ı puərt $\int \mathrm{Iz}$ bo: did hay mə:I hevi (w)uəkən duər ən In bijand ən pn ठə vluər ði iivmən d $\Lambda$ sk did gaðər slo: bət brə:It did gljeər ðə twinklən spuəks ə rınən karid3 (h)willz əz vo:ks ərut iist did rə:Id əlpy ðə ro:d bizə:Id ðə lo:bə:ud (w)uəks

ən ə:Id əlpst ðə zムn vrəm vju: nntıl əgjen (h)Iz fjes mid rə:Iz ə)iinən vrəm ði i:stərn skə:Iz tə brə:itən $\Lambda p$ бə ruəzba:rn dju: bət strl (h)Iz lingrən lə:it did gi: mə: (h)Iz bi:mz $\partial \int \varepsilon d$ wi strat $\int ə n \int j \varepsilon d$ pn i:stwərd wa:l on tri:

(h)wen dzæi əzent mi: vrəm əb $\Lambda \mathrm{v}$ vrəm mə:I sad ha:rt Iz nə:u əgpn ən $\Lambda$ ðrz bi: əwع:kən pn əmid ðə lə:It əv hevənz $1 \Lambda \mathrm{v}$ 
Oh! then vor lovèn-kindness seäke,

Mid I rejäice that zome do teäke

may

My hopes a-gone, until ageän

My happy dawn do breäk. 


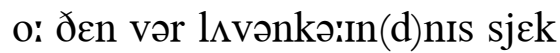
mId ə:I ridzæis ðət z $\Lambda \mathrm{m}$ də tjek mə:I ho:ps əgpn $\Lambda$ ntıl əgjen mə:I hapi de:n də bre:k 
VIELDS BY WATERVALLS

WHEN our downcast looks be smileless,

Under others' wrongs an' slightèns,

When our daily deeds be guileless,

An' do meet unkind requitèns,

You can meäke us zome amends

Vor wrongs o' foes, an' slights o' friends; -

O flow'ry-gleäded, timber-sheäded

Vields by flowèn watervalls!

Here be softest aïrs a-blowèn

Drough the boughs, wi' zingèn drushes,

through, thrushes

Up above the streams, a-flowèn

Under willows, on by rushes.

Here below the bright-zunn'd sky

The dew-bespangled flow'rs do dry,

In woody-zided, stream-divided

Vields by flowèn watervalls.

Waters, wi' their giddy rollèns;

Breezes wi' their plaÿsome wooèns;

Here do heal, in soft consolèns,

Hearts a-wrung wi' man's wrong doèns.

Day do come to us as gaÿ

As to a king ov widest swaÿ,

In deäisy-whitèn'd, gil'cup-brightèn'd

buttercup-

Vields by flowèn watervalls.

Zome feäir buds mid outlive blightèns, may

Zome sweet hopes mid outlive sorrow,

After days of wrongs an' slightèns

There mid break a happy morrow. 
vi:l(d)z b(ə:)I wə:tərva:lz

(h)wen ə:uər də:unka:st luks bi: smə:Illis

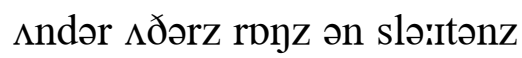

(h)wen ə:uər de:li di:dz bi: gə:Illıs ən də mi(:)t $\Lambda$ nkə:In(d) rikwə:Itənz ju: kən mjek əs $\mathrm{z} \Lambda \mathrm{m}$ əmen(d)z vər rpyz ə fo:z ən sləitts ə fren(d)z o: flə:uərigljedid tımbər $j$ jedid vi:l(d)z b(ə:)I flo:ən wo:tərva:lz

hiər bi: spftist æIrz əblo:ən dru: ðə bə:uz wi zingən $\operatorname{dr} \Lambda \int \mathrm{Iz}$

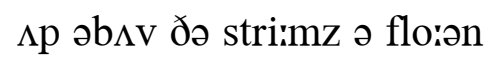
$\Lambda$ ndər wilərz pn b(əi) I $\mathrm{r} \Lambda \int \mathrm{Iz}$ hiər bilo: ðə brə:Itzınd skə:I ðə dju:bispaygəld flə:uərz də drə:I In wudizə:Idıd stri:mdivə:IdId vi:l(d)z b(ə:) I flo:ən wo:tərva:lz

wo:tərz wi ðər gidi ro:lənz bri:zız wi ðər plæIsəm wu:ənz hiər də hi:l in spft kənso:lənz ha:rts ər^y wi manz roy duiənz de: də kım tu $\Lambda$ s əz gæI əz tu ə kin əv wə:Idist swæI In djezi(h)wə:Itənd gilkıpbrə:Itənd vi:l(d)z b(ə:) I flo:ən wo:tərva:lz

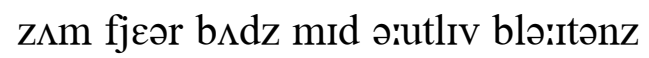
zım swi(:)t ho:ps mid əutliv sarə(r) ع:tər de:z əv ronz ən slə:itənz ðər mid bre:k ə hapi marə(r) 
We mid have noo e'thly love;

earthly

But God's love-tokens vrom above

Here mid meet us, here mid greet us.

In the vields by watervalls. 
wi: mid hav nu: $\varepsilon \theta 1 i 1 \Lambda \mathrm{v}$

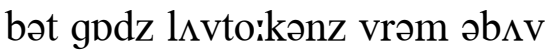

hiər mId mitt əs hiər mid gri:t əs

In ðə vi:l(d)z b(ə:)I wə:tərva:lz 
'Tis true I brought noo fortune hwome

Wi' Jenny, vor her honey-moon,

But still a goodish hansel come

wedding present

Behind her perty soon,

Vor stick, an' dish, an' spoon, all vell

To Jeäne, vrom Aunt o’ Camwy dell.

Zoo all the lot o' stuff a-tied

so

Upon the plow, a tidy tod, wagon, load

On gravel-crunchèn wheels did ride,

Wi' ho'ses, iron-shod,

That, as their heads did nod, my whip

Did guide along wi' lightsome flip.

An' there it rod 'ithin the rwope, rode

Astraïn'd athirt, an' straïn'd along, across

Down Thornhay's evenèn-lighted slope

An' up the beech-tree drong; lane

Where wheels a-bound so strong, cut out

On either zide a deep-zunk rout. rut

An' when at Fall the trees wer brown,

Above the bennet-bearèn land,

When beech-leaves slowly whiver'd down,

By evenèn winds a-fann'd;

The routs wer each a band o' red,

A-vill'd by drifted beech-leaves dead.

An' when, in Winter's leafless light,

The keener eastern wind did blow,

An' scatter down, avore my zight,

A chilly cwoat o' snow; 
ðə (h)will rə:uts

tIz tru: ə:I bro:t nu: fa:rtju:n huəm

wi dz๕ni vər (h)ər h^nimu:n

bət stil ə gudis hansəl kım

bihə:In(d) (h)ər pərrti su:n

vər strk on dif ən spu:n a:l vel

tə djjen vrəm $\varepsilon$ :nt ə kamwi del

zu: a:l ðə lpt ə st $\Lambda$ f ətə:Id

әppn ðə plə:u ə tə:Idi tod

pn gravəlkrıntfən (h)wi:lz did rə:Id

wi hpsiz ə:ıərn $\int p d$

ðət az ðər hedz did nod mə:I (h)wip

did gə:Id əlpy wi lə:Itsəm flıp

ən ðər It rpd IðIn ðə ruəp

əstræInd əðə:rt ən stræInd əlpy

dərun ða:rnhæız i:vmənlə:itıd slo:p

ən $\Lambda$ p ðə bi:tftri: dron

(h)wər (h)wi:lz əbə:un(d) sə strpy kıt ə:ut

pn ə:Iðər zə:Id ə di:pzıyk rə:ut

ən (h)wen ət fa:l ðə tri:z wər brə’un

əb $\Lambda \mathrm{v}$ ðə benitbeərən lan(d)

(h)wen bittfliivz slo:li (h)wivərd dərun

b(ə:)I i:vmən wIn(d)z əfand

ðə rə:uts wər itt ə ban(d) ə red

əvild b(ə:)I drIftıd bi:tfliivz ded

ən (h)wen In wintərz li:flıs lə:it

ðə ki:nər isstərn win(d) did blo:

ən skatər də:un əvuər mə:I zə:It

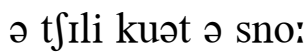


The routs ageän did show vull bright,

In two long streaks o' glitt'rèn white.

But when, upon our weddèn night,

The cart's light wheels, a-rollèn round,

Brought Jenny hwome, they run too light

To mark the yieldèn ground;

Or welcome would be vound a peäir

O' green-vill'd routs a-runnèn there.

Zoo let me never bring 'ithin

My dwellèn what's a-won by wrong,

An' can't come in 'ithout a sin;

Vor only zee how long

The waggon marks in drong, did show

lane

Wi' leaves, wi' grass, wi' groun' wi' snow. 
ðə rə:uts əgjen did fo: vul brə:It In tu: lpy stri:ks ə glitrən (h)wə:It

bət (h)wen əppn ə:uər wedən nə:It

ðə ka:rts lə:It (h)wi:lz əro:lən rə:un(d)

bro:t dzeni huəm ðe: rın tu: lə:it

tə ma:rk ðə jiildən grə:un(d)

ar welkəm wud bi: və:un(d) ə pjeər

ə gri:nvild rə:uts ər^nən ðعər

zu: let mi: nevər brı ıðın

mə:I dwelən (h)wots əwیn b(ə:)I roy

ən ke:nt kım In Iðə:ut ə sin

vər o:nli zi: hə:u lpy

ðə wagən ma:rks in droy did So:

wi li:vz wi gra:s wi grəun wi sno: 
Now day by day, at lofty height,

$\mathrm{O}$ zummer noons, the burnèn zun

'Ve a-show'd avore our eastward zight,

The sky-blue zide ov Hameldon,

An' shone ageän, on new-mow'd ground,

Wi' hay a-piled up grey in pook,

An' down on leäzes, bennet-brown'd,

An' wheat a-vell avore the hook;

a cone

meadows, dead grass-stalks

Till, under elems tall,

The leaves do lie on leänèn lands,

In leäter light o’ Fall.

An' last year, we did zee the red

O' dawn vrom Ash-knap's thatchen oves,

eaves

An' walk on crumpled leaves a-laid

In grassy rook-trees' timber'd groves,

Now, here, the cooler days do shrink

To vewer hours o' zunny sky,

While zedge, a-weävèn by the brink

O' shallow brooks, do slowly die.

An' on the timber tall,

The boughs, half beäre, do bend above

bare

The bulgèn banks in Fall.

There, we'd a spring o' water near,

Here, water's deep in wink-draïn'd wells,

winch-

The church 'tis true, is nigh out here,

Too nigh wi' vive loud-boomèn bells.

There, naïghbours wer vull wide a-spread,

But vo'k be here too clwose a-stow'd. 
naniz nju: əbo:d

nə:u de: b(ə:)I de: ət lpfti hə:It

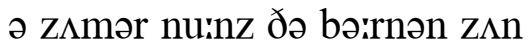

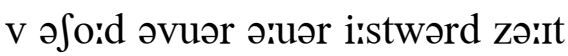

ðə skə:Iblu: zə:Id əv haməldən

ən $\int$ pn əgjen pn nju: mo:d grə:und

wi hæi әрә:Ild $\Lambda$ p gre: in puk

ən də:un pn liəzız benttbrə:und

ən (h)witt əvعl əvuər ðə huk

til $\Lambda$ ndər عləmz ta:l

ðə liivz də lə:ı pn liənən $\operatorname{lan}(\mathrm{d}) \mathrm{z}$

In ljetər lə:It ə fa:1

ən le:st jiər wi: did zi: ðə red

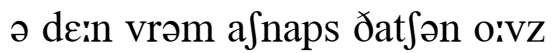

ən we:k pn krımpəld li:vz əled

In graisi ruktri:z timbərd gro:vz

nə:u hiər ðə ku:lər de:z də Jrınk

to vju:ər ə:uərz ə zムni skə:I

(h)wə:Il zedz əwjevən b(ə:)I ðə brıjk

ə Salər bruks də slo:li də:I

ən pn ðə tımbər ta:l

ðə bə:uz he:f bjeər də ben(d) əbムv

ðə bᄉldzən bayks in fa:l

ðعər wi:d ə sprın ə wo:tər niər

hiər wo:tərz disp in winkdræind welz

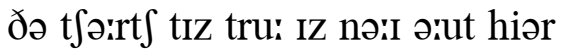

tu: nə:I wi və:IV lə:udbu:mən belz

ðعər næibərz wər vul wə:Id əspred

bət vo:k bi: hiər tu: kluəs əsto:d 
Vor childern now do stun woone's head, one's Wi' naiss plaÿ bezide the road, Where big so well as small, The little lad, an' lump'rèn lout, Do leäp an' laugh theäse Fall. this 
vər t t Ildərn nə:u də st $\Lambda$ n (w)u:nz hed wi næızi plæı bızə:Id ðə ro:d (h)wər brg sə wel əz sma:l ðə 1itəl lad ən 1^mprən lə:ut də liəp ən le:f ðiəs fa:l 
THERE the ash-tree leaves do vall

In the wind a-blowèn cwolder, An' my childern, tall or small,

Since last Fall be woone year wolder.

one, older

Woone year wolder, woone year dearer,

Till when they do leäve my he'th, bearth

I shall be noo mwore a hearer

O' their vaïces or their me'th.

mirth

There dead ash leaves be a-toss'd

In the wind, a-blowèn stronger,

An' our life-time, since we lost

Souls we lov'd, is woone year longer.

Woone year longer, woone year wider,

Vrom the friends that death ha' took,

As the hours do teäke the rider

Vrom the hand that last he shook.

No. If he do ride at night

Vrom the zide the zun went under,

Woone hour vrom his western light

Needen meäke woone hour asunder;

Woone hour onward, woone hour nigher

To the hopeful eastern skies,

Where his mornèn rim o vier

fire

Soon ageän shall meet his eyes.

Leaves be now a-scatter'd round

In the wind, a-blowèn bleaker, An' if we do walk the ground

Wi' our life-strangth woone year weaker. 
liivz əva:lən

ðər ði aftri: li:vz də va:l

In ðə $\operatorname{win}(\mathrm{d})$ əblo:ən kuəldər

ən mə:I t $t$ Ildorn ta:l or sma:l

sins le:st fa:l bi: (w)u:n jiər (w)uəldər

(w)u:n jiər (w)uəldər (w) unn jiər diərər

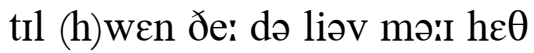

ə:I $\int ə l$ bi: nu: muər ə hiərər

ə ðər væIsIz ar ðər me $\theta$

ðər ded a li:vz bi: ətpst

In ðə wIn(d) əblo:ən strpygər

ən ə:uər lə:Iftə:Im sins wi: lost

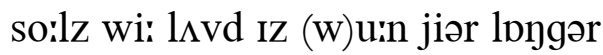

(w)u:n jiər lpygər (w)u:n jiər wə:Idər

vrəm ðə fren (d)z ðət $d \varepsilon \theta$ hə tuk

az ði ə:uərz də tjek ðə rə:Idər

vrəm ðə han(d) ðət le:st hi: Juk

no: If hi: də rə:Id ət nə:It

vrəm ðə zə:Id ðə z^n went $\Lambda$ ndər

(w)uin ə:uər vrəm (h)Iz westərn lə:It

ni:dən mjek (w)u:n ə:uər əs $\Lambda$ ndər

(w)u:n ə:uər pn(w)ərd (w)u:n ə:uər nə:ıər

ə ठə ho:pful iistərn skə:Iz

(h)wər (h)Iz ma:rnən rım ə və:ıər

su:n əgjen $\int \partial l \mathrm{mi}(:) \mathrm{t}(\mathrm{h}) \mathrm{IZ}$ ə:IZ

liivz bi: nə:u əskatərd rə:un(d)

In ðə $\operatorname{wIn}(d)$ əblo:ən blikkər

ən If wi: də we:k ðə grə:un(d)

wi ə:uər lə:Ifstray $\theta$ (w)uin jiər wi:kər 
Woone year weaker, woone year nigher

To the pleäce where we shall vind Woone that's deathless vor the dier,

Voremost they that dropp'd behind. 
(w)u:n jiər wi:kər (w)uin jiər nəiər

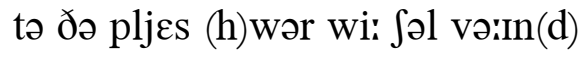

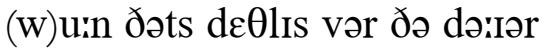

vuərmo:st ðe: ðət drapt bihə:In(d) 
O LIZZIE is so mild o' mind, Vor ever kind, an' ever true; A-smilèn, while her lids do rise

To show her eyes as bright as dew.

An' comely do she look at night, A-dancèn in her skirt o' white, An' blushèn wi' a rwose o' red

Bezide her glossy head.

Feäir is the rwose o' blushèn hue,

Behung wi' dew, in mornèn's hour,

Feäir is the rwose, so sweet below

The noontide glow, bezide the bow'r.

Vull feäir, an' eet I'd rather zee yet

The rwose a-gather'd off the tree,

An' bloomèn still with blossom red,

By Lizzie's glossy head.

Mid peace droughout her e'thly day, Betide her waÿ, to happy rest, An' mid she, all her weanèn life, may, throughout, earthly

Or maïd or wife, be loved and blest.

Though I mid never zing anew

To neäme the maïd so feäir an' true, A-blushèn, wi' a rwose o' red, Bezide her glossy head. 
lızi

o: lizi Iz sə mə:Ild ə mə:In(d)

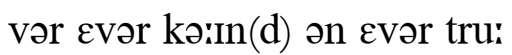

əsmə:Ilən (h)wə:Il (h)ər lidz də rə:Iz

tə fo: (h)ər ə:Iz əz brə:It əz dju:

ən kımli də Ji: luk ət nə:It

əde:nsən In (h)ər skərrt ə (h)wə:It

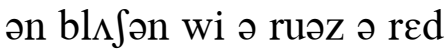

bizə:Id (h)ər glosi hed

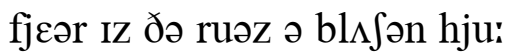

bihıy wi dju: in marnənz ə:uər

fjeər iz ðə ruəz sə swi(:)t bilo:

ðə nu:ntə:Id glo: bizə:Id ðə bə:uər

vul fjeər ən i:t ə:Id re:ðər zi:

ðə ruəz əgaðərd pf ðə tri:

ən bluimən stıl wi(ð) blpsəm red

b(ə:)I lıziz glpsi hed

mid piss dru:ərut (h)ər $\varepsilon \theta l i$ de:

bitəitd (h)ər we: to hapi rest

ən mId fi: a:l (h)ər wjenən lə:If

ar mæid ar wə:If bi: $1 \Lambda \mathrm{vd}$ ən(d) blest

ðo: ə:I mId nevər zIn ənju:

tə njem ðə mæId sə fjeər ən tru:

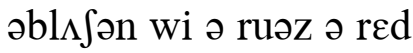

bizə:Id (h)ər glpsi hed 
LIK' souls a-toss'd at sea I bore

Sad strokes o' trial, shock by shock, An' now, lik' souls a-cast ashore

To rest upon the beäten rock, I still do seem to hear the sound

O' weäves that drove me vrom my track, An' zee my strugglèn hopes a-drown'd, An' all my jaÿs a-floated back.

By storms a-toss'd, I'll gi'e God praïse, give Wi' much a-lost I still ha' jaÿs.

My peace is rest, my faith is hope, An' freedom's my unbounded scope.

Vor faith mid blunt the sting o' fear, may An' peace the pangs ov ills a-vound, An' freedom vlee vrom evils near,

Wi' wings to vwold on other ground. fly

Wi' much a-lost, my loss is small,

Vor though ov e'thly goods bereft, A thousand times well worth em all Be they good blessèns now a-left. What e'th do own, to e'th mid vall, earth But what's my own my own I'll call, My faïth, an' peäce, the gifts o' greäce, An' freedom still to shift my pleäce.

When I've a-had a tree to screen

My meal-rest vrom the high zunn'd-sky,

Or ivy-holdèn wall between

My head an' win's a-rustlèn by, 
blesənz əleft

lik so:lz ətpst at si: ə:I buər sad stro:ks ə trə:ıəl $\int \mathrm{pk} b(\partial:) \mathrm{l} \int \mathrm{pk}$ ən nə:u lik so:lz əka:st əfuər tə rest əppn ðə biətən rok ə:I strl də si(:)m to hiər ðə sə:und ə wjevz ðət dro:v mi: vrəm mə:I trak ən zi: mə:I strıglən ho:ps ədrə:und ən ail mə:I dzæiz əflo:tıd bak b(ə:)I sta:rmz ətpst əsil gi: gpd præIz wi m $\Lambda$ t $\int$ əlpst ə:I stıl hə dzæIz mə:I piss iz rest mə:I fæi $\theta$ iz ho:p on friidəmz mə:i $\Lambda$ nbə:undid sko:p

vər fær $\theta$ mId blınt ðə stın ə fiər ən piss ðə payz əv ilz əvərun(d) ən fri:dəm vli: vrəm iivəlz niər wi winz to vuəld pn $\Lambda$ ðə grə:un(d) wi mıt $\int$ əlpst mə:I lps Iz sma:l vər ðo: əv ع $\theta$ li gudz bireft ə $\theta$ ว:uzən(d) tə:Imz wel wp $\theta$ əm a:l bi: ðe: gud blesənz nə'u əleft (h)wpt $\varepsilon \theta$ du o:n tu $\varepsilon \theta$ mid va:l bət (h)wpts mə:I o:n mə:I o:n ə:Il ka:l mə:I fæi $\theta$ ən piəs ðə gifts ə grjes ən fri:dəm stıl to $\mathrm{JIft}$ mə:I pljes

(h)wen ə:IV əhad ə tri: to skri:n mə:I mi:lrest vrəm ðə hə:I Zındskə:I ər ə:Ivihuəldən wail bitwi:n mə:I hed ən win(d)z ər $\Lambda$ slən bə:I 
I had noo call vor han's to bring

Their seäv'ry daïnties at my nod,

savoury

But stoop'd a-drinkèn vrom the spring,

An' took my meal, wi' thanks to God,

Wi' faith to keep me free o' dread,

An' peäce to sleep wi' steadvast head,

An' freedom's hands, an' veet unbound

To woone man's work, or woone seäme ground.

one 
ə:I had nu: ka:l vor hanz to brin ðər sjevri dæIntiz ət mə:I npd bət stu:pt ədrı̄kən vrəm ðə sprin ən tok mə:I mill wi $\theta$ ayks to gpd wi fær $\theta$ to ki(:)p mi: fri: ə dred ən piəs tə sli:p wi stedvaist hed ən fri:dəmz han(d)z ən vi:t $\Lambda$ nbərun(d) to (w)u:n manz wərrk or (w)u:n sjem grərun(d) 
FALL TIME

THE gather'd clouds, a-hangèn low,

Do meäke the woody ridge look dim;

An' raïn-vill'd streams do brisker flow,

Arisèn higher to their brim.

In the tree, vrom lim' to lim',

Leaves do drop

Vrom the top, all slowly down,

Yollow, to the gloomy groun'.

The rick's a-tipp'd an' weather-brown'd, rain-proofed $d^{3}$

An' thatch'd wi' zedge a-dried an' dead;

An' orcha'd apples, red half round,

Have all a-happer'd down, a-shed

Underneath the trees' wide head.

Ladders long,

Rong by rong, to clim' the tall

rung, climb

Trees, be hung upon the wall.

The crumpled leaves be now a-shed

In mornèn winds a-blowèn keen;

When they wer green the moss wer dead,

Now they be dead the moss is green.

Low the evenèn zun do sheen

shine

By the boughs,

Where the cows do swing their tails

Over the merry milkers' pails.

\footnotetext{
3 “"To tip a rick," to make its top conical and sharp so as to shoot the wet, by raking and pulling loose hay from its side and undercutting it and putting the hay gotten from these operations on the top' (1844 Glossary).
} 
fa:l tə:Im

ðə gaðərd klə:udz əhayən lo:

də mjek ðə wudi r $\Lambda$ d3 luk dim

ən ræinvild stri:mz də briskər flo:

ərə:Izən hə:Iər tə ðər brim

In ðə tri: vrəm lim to $1 \mathrm{Im}$

li:vz do drap

vrəm ðə top a:l slo:li də:un

jalər tə ðə glu:mi grə:un

ðə riks ətıpt ən weðərbrə:und

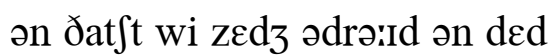

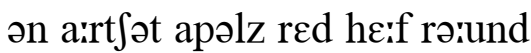

həv a:l əhapərd də:un $ə \int \varepsilon d$

$\Lambda$ ndərne: $\theta$ ðə tri:z wə:Id hed

laðərz lpy

roy b(ə:)I roy tə klım ðə ta:l

tri:z bi: h^y әppn ðə wa:l

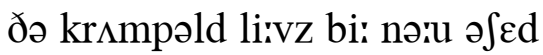

In ma:rnən win(d)z əblo:ən ki:n

(h)wen ðе: wər gri:n ðə mps wər ded

nə'u ðе: bi: ded ðə mps Iz gri:n

lo: ði i:vmən zAn də Siin

b(ə:)I ðə bə:uz

(h)wər ðə kə:uz də swiy ðər tæIlz

ə:vər ðə meri mılkərz pæılz 
FALL

Now the yollow zun, a-runnën

Daily round a smaller bow, $\operatorname{arc}$

Still wi' cloudless sky's a-zunnèn

All the sheenèn land below.

Vewer blossoms now do blow, shining bloom

But the fruit's a-showèn

Reds an' blues, an' purple hues,

By the leaves a-glowèn.

Now the childern be a-pryèn

Roun' the berried bremble-bow,

Zome a-laughèn, woone a-cryèn

one

Vor the slent her frock do show.

tear

Bwoys be out a-pullèn low

Slooe-boughs, or a-runnèn

sloe-

Where, on zides of hazzle-wrides, bazel-clumps

Nuts do hang a-zunnèn.

Where do reach roun' wheat-ricks yollow

Oves o' thatch, in long-drawn ring, eaves

There, by stubbly hump an' hollow,

Russet-dappled dogs do spring.

Soon my apple-trees wull fling

Bloomèn balls below em,

That shall hide, on ev'ry zide

Ground where we do drow em.

throw 
fa:l

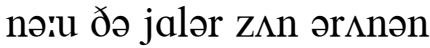

de:li rə:un(d) ə sma:lər bo:

stıl wi klə:udlıs skə:Iz əzムnən

a:l ðə fi:nən lan(d) bilo:

vju:ər blpsəmz nə:u də blo:

bət ðə fruits əरo:ən

redz ən blu:z ən pə:rpəl hju:z

b(ə:)I ðə liivz əglo:ən

nə:u ðə tfIldərn bi: əprə:ıən

rə:un ðə berid brembəlbo:

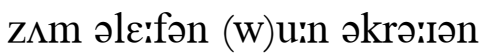

vər ðə slent (h)ər frok də Jo:

bwə:Iz bi: ə:ut əpulən lo:

slu:bə:uz ar ərınən

(h)wər pn zə:Idz əv hazəlrə:Idz

nıts də hay əzムnən

(h)wər də riit rə'un (h)wi:triks jalər

o:vz ə ðat $\int$ in lpydre:n rin

ðər b(ə:)I st $\lrcorner$ bli hımp ən hplər

r $\Lambda$ sətdapəld dogz də sprin

su:n mə:I apəltri:z wul flin

blu:mən ba:lz bilo: əm

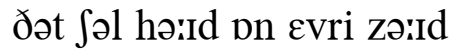

grə:un(d) (h)wər wi: də dro: əm 
THE zilver-weed upon the green,

Out where my sons an' daughters plaÿ'd,

Had never time to bloom between

The litty steps o' bwoy an' maid.

light

But rwose-trees down along the wall,

That then wer all the maïdens' ceäre,

An' all a-trimm'd an' traïn'd, did bear

Their bloomèn buds vrom Spring to Fall.

But now the zilver leaves do show

To zummer day their goolden crown,

Wi' noo swift shoe-zoles' litty blow,

In merry plaÿ to beät em down.

An' where vor years zome busy hand

Did train the rwoses wide an' high;

Now woone by woone the trees do die,

one by one

An' vew of all the row do stand. 
ðə zılvərwi:d

ðə zIlvərwi:d əppn ðə gri:n

ə:ut (h)wər mə:I s $\Lambda$ nz ən de:tərz plæıd had nevər tə:Im to blu:m bitwi:n

ðə liti steps ə bwə:I ən mæid bət ruəztri:z də:un əlpy ðə wa:l

ðət ðعn wər a:l ðə mæIdənz kjeər on a:l ətrimd on træind did beər

ðər blu:mən b^dz vrəm sprin tə fa:l

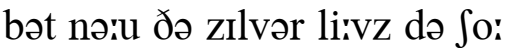

to z^mər de: ðər guildən krəiun

wi nu: swift $\int u: z o: l z$ liti blo:

In meri plæi tə biət əm də:un

ən (h)wər vər jiərz z^m bizi han(d)

did træIn ðə ruəzIz wə:Id ən hə:I

nə:u (w)u:n b(ə:)I (w)u:n ðə tri:z də də:I

ən vju: əv a:l ठə ro: də $\operatorname{stan}(\mathrm{d})$ 
I WENT hwome in the dead o' the night,

When the vields wer all empty o' vo'k, An' the tuns at their cool-winded height folk
chimney-tops

Wer all dark, an' all cwold 'ithout smoke;

An' the heads o' the trees that I pass'd

Wer a-swaÿèn wi' low-ruslèn sound, An' the doust wer a-whirl'd wi' the blast, dust Aye, a smeech wi' the wind on the ground.

thick dust

Then I come by the young widow's hatch,

Down below the wold elem's tall head, wicket-gate

But noo vinger did lift up the latch,

Vor the vo'k wer so still as the dead;

But inside, to a tree a-meäde vast, fast

Wer the childern's light swing, a-hung low, An' a-rock'd by the brisk-blowèn blast,

Aye, a-swung by the win' to an' fro.

Vor the childern, wi' pillow-borne head,

Had vorgotten their swing on the lawn, An' their father, asleep wi' the dead,

Had vorgotten his work at the dawn;

An' their mother, a vew stilly hours,

Had vorgotten where he sleept so sound,

Where the wind wer a-sheäkèn the flow'rs,

Aye, the blast the feäir buds on the ground.

shaking

Oh! the moon, wi' his peäle lighted skies,

Have his sorrowless sleepers below.

But by day to the zun they must rise

To their true lives o' tweil an' ov ho. 
ðə widərz hə’us

ə:I went huəm In ðə ded ə ðə nə:It

(h)wen ðə vi:l(d)z wər a:l $\varepsilon m(p)$ ti ə vo:k

ən ठə tムnz ət ðər ku:lwindid hə:It

wər a:l da:rk ən a:l kuəld ıðə:ut smo:k

ən ðə hedz ə ðə tri:z ðət ə:I pa:st

wər əswæiən wi lo:r $\Lambda$ slən sə:un(d)

ən ठə də:ust wər ə(h)wərrld wi ðə bla:st

æI ə smi:t $\int$ wi ðə win(d) pn ठə grə:un(d)

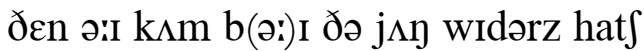

də:un bilo: ðə (w)uəld عləmz ta:l hed

bət nu: vingər did lift $\Lambda p$ ðə lat

vər ðə vo:k wər sə stıl əz ðə ded

bət InsəiId tu $ə$ tri: əmjed vaist

wər ðə tfildərnz lə:It swin əh^y lo:

ən ərpkt b(ə:)I ðə briskblo:ən blaist

æI əSWAy b(ə:)I ठə WIn(d) tu: ən fro:

var ðə t fildərn wi pilərba:rn hed

had vərgptən ðər swin pn ðə le:n

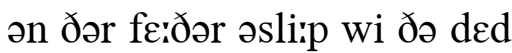

had vərgptən (h)IZ wərrk ət ðə de:n

ən ðər m^ðər ə vju: strli ə:uərz

had vərgptən (h)wər hi: sli:pt sə sə:un(d)

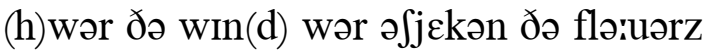

æI ðə bla:st ðə fjeər b $\Lambda \mathrm{dz}$ pn ðə grə:un(d)

o: ðə mu:n wi (h)Iz pjel lə:ItId skə:Iz

hav (h)Iz sarə(r)lis sli:pərz bilo:

bət b(ə:)I de: tə ðə zAn ðе: məst rə:Iz

tə ðər tru: lə:IVZ ə twəill ən əv ho: 
Then the childern wull rise to their fun, An' their mother mwore sorrow to veel, While the air is a-warm'd by the zun, Aye, the win' by the day's vi'ry wheel. 


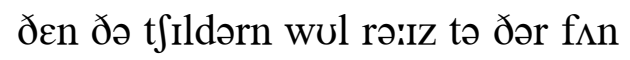
ən ðər $\mathrm{m} \Lambda$ ðər muər sarə(r) to vi:l

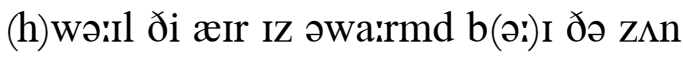

æI ðə wIn(d) b(əi)I ðə de:z və:ıəri (h)will 


\section{THE CHILD’S GREÄVE}

AVOrE the time when zuns went down

On zummer's green a-turn'd to brown,

When sheädes o' swaÿèn wheat-eärs vell shadows

Upon the scarlet pimpernel;

The while you still mid goo, an' vind might

'Ithin the geärden's mossy wall, Sweet blossoms, low or risèn tall, To meäke a tutty to your mind, nosegay

In churchyard heav'd, wi' grassy breast, The greäve-mound ov a beäby's rest.

An' when a high day broke, to call A throng 'ithin the churchyard wall, The mother brought, wi' thoughtvul mind, The feäirest buds her eyes could vind, To trim the little greäve, an' show

To other souls her love an' loss, An' meäde a Seävior's little cross O' brightest flow'rs that then did blow, bloom A-droppèn tears a-sheenèn bright, Among the dew, in mornèn light.

An' woone sweet bud her han' did pleäce one

Up where did droop the Seävior's feäce;

An' two she zet a-bloomèn bright,

Where reach'd His hands o' left an' right;

Two mwore feäir blossoms, crimson dyed,

Did mark the pleäces ov his veet, An' woone did lie, a-smellèn sweet, Up where the spear did wound the zide Ov Him that is the life ov all Greäve sleepers, whether big or small. 


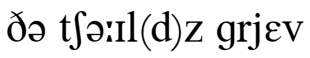

əvuər ठə tə:Im (h)wعn z^nz went də:un

pn zımərz griin ətərrnd to brə:un

(h)wen $\int j \varepsilon d z$ ə swæıən (h)wi:tiərz vel

əppn ðə ska:rlit pimpərnel

ðə (h)wə:Il jə stıl mid gu: ən və:In(d)

ıðın ðə gja:rdənz mpsi wa:l

swi(:)t blosəmz lo: ar rə:Izən ta:l

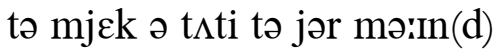

In tfə:rtfja:rd hi:vd wi gra:si brest

ðə grjevmə:un(d) əv ə bjebiz rest

ən (h)wen ə hə:I de: bro:k to ka:l

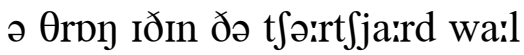

ðə m^ðər bro:t wi $\theta$ s:tvul mə:In(d)

ðə fjeərəst bıdz (h)ər ə:Iz kud və:In(d)

tə trim ðə litəl grjev ən Jo:

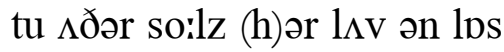

ən mjed ə sjevjərz litəl kros

ə brə:ItIst flə:uərz ðət ðعn did blo:

ədrapən tiərz əfi:nən brə:It

əmpy ðə dju: In ma:rnən lə:It

ən (w)u:n swi(:)t bıd (h)ər han did pljes

$\Lambda \mathrm{p}$ (h)wər did dru:p ðə sjevjərz fjes

ən tu: $\int i$ i: zet əblu:mən brə:It

(h)wər ri:t dd (h)Iz han(d)z ə left ən rə:It

tu: muər fjeər blosəmz krimzən də:Id

did marrk ðə pljesız əv (h)Iz vi:t

ən (w)u:n did lə:I əsmelən swi:t

$\Lambda \mathrm{p}$ (h)wər ðə spiər did wə:un(d) ðə zə:Id əv hIm ðət Iz ðə lə:If əv a:l

grjev sli:pərz (h)weðər big ər sma:l 
The mother that in faith could zee

The Seävior on the high cross tree

Mid be a-vound a-grievèn sore,

But not to grieve vor evermwore,

Vor He shall show her faïthvul mind,

His chaice is all that she should choose,

An' love that here do grieve to lose,

Shall be, above, a jaÿ to vind,

joy

Wi' Him that evermwore shall keep

The souls that He do lay asleep. 
ðə m^ðər ðət in fæiӨ kud zi:

ðə sjevjər pn ðə hə:I krps tri:

mid bi: əvə:un(d) əgriivən suər

bət npt to gri:v vər Evərmuər

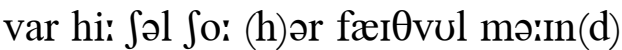

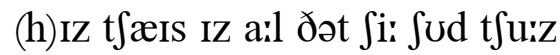

ən $1 \Lambda \mathrm{v}$ ðət hiər də griiv to lu:z

Səl bi: əbムv ə dzæi tə və:In(d)

wi hım ðət عvərmuər Jəl ki:p

ðә so:lz ðət hi: də le: əsli:p 
THE stream-be-wander'd dell did spread Vrom height to woody height, An' meäds did lie, a grassy bed, Vor elem-sheädèn light.

The milkmaïd by her white-horn'd cow, Wi' pail so white as snow, Did zing below the elem bough

A-swaÿèn to an' fro.

An' there the evenèn's low-shot light

Did smite the high tree-tops,

An' rabbits vrom the grass, in fright,

Did leäp 'ithin the copse.

An' there the shepherd wi' his crook, An' dog bezide his knee,

Went whisslèn by, in air that shook

The ivy on the tree.

An' on the hill, ahead, wer bars

A-showèn dark on high,

Avore, as eet, the evenèn stars

Did twinkle in the sky,

An' then the last sweet evenèn-tide

That my long sheäde vell there, shadow

I went down Brindon's thymy zide,

To my last sleep at Ware. 
went vrəm huəm

ðə stri:mbi:wpndərd del did spred

vrəm hə:It to wudi hə:It

ən miədz did lə:I ə gra:si bed

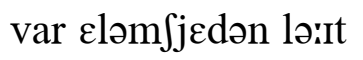

ðə milkmæId b(ə:)I (h)ər (h)wə:Itha:rnd kə:u

wi pæil sə (h)wə:It əz sno:

did zig bilo: ði عləm bə:u

əswæIən tu: ən fro:

ən ðər ði i:vmənz lo: $\int p t$ lə:It

did smə:It ðə hə:I tri:tpps

ən rabits vrəm ðə gra:s in frə:It

did liəp ıðın ðə kpps

ən ðər ðə $\int \varepsilon p ə r d$ wi (h)Iz kruk

ən dpg bizə:Id (h)Iz ni:

went (h)wislən bə:I In æIr ðət $\int u k$

ði ə:Ivi pn ðə tri:

ən pn ðə hil əhed wər ba:rz

əरo:ən darrk pn hə:I

əvuər az i:t ði iivmən sta:rz

did twinkəl in ðə skə:I

ən ðعn ðə le:st swi(:)t i:vməntə:Id

ðət mə:I lpy $\int j \varepsilon d ~ v \varepsilon l ~ ð \varepsilon ə r$

ว:I went də:un brindənz tə:Imi zə:Id

to mə:i le:st sli:p ət weər 
THE Frome, wi' ever-water'd brink,

Do run where shelvèn hills do zink:

sloping

Wi' housen all a-cluster'd roun'

The parish tow'rs below the down.

An' now, vor woonce, at leäst, ov all

The pleäcen where the stream do vall,

There's woone that zome to-day mid vind,

Wi' things a-suited to their mind.

An' that's out where the Fancy Feäir

Is on at Maïden Newton.

An' vo'k, a-smarten'd up, wull hop

Out here, as ev'ry traïn do stop,

Vrom up the line, a longish ride,

An' down along the river-zide.

An' zome do beät, wi' heels an' tooes,

The leänes an' paths, in nimble shoes,

An' bring, bezides, a biggish knot,

Ov all their childern that can trot,

A-vlockèn where the Fancy Feäir

Is here at Maïden Newton.

If you should goo, to-day, avore

A Chilfrome house or Downfrome door,

Or Frampton's park-zide row, or look

Drough quiet $W$ raxall's slopy nook,

through

Or elbow-streeted Catt'stock, down

By Castlebill's cwold-winded crown,

An' zee if vo'k be all at hwome,

You'd vind em out - they be a-come

Out hither, where the Fancy Feäir

Is on at Maïden Newton. 
ðə fansi fjeər ət mæIdən nju:tən

ðə fru:m wi عvərwə:tərd brınk də r $\Lambda$ n (h)wər $\int \varepsilon l v ə n$ hilz də zıjk wi hə:uzən a:l əklıstərd rə:un ðə pari $\int$ tə:uərz bilo: ðə də:un ən nə:u vər (w)u:ns ət liəst əv a:l ðə pljєzən (h)wər ðə stri:m də va:l ðərz (w)u:n ðət z^m təde: mId və:In(d) wi ðınz əsu:tıd tə ðər mə:In(d) ən ðats ə:ut (h)wər ðə fansi fjeər IZ pn ət mæidən nju:tən

ən vo:k əsma:rtənd $\Lambda p$ wul hpp ə:ut hiər $ə z$ evri træin də stpp vrəm $\Lambda$ р ðə lə:In ə lpyI rə:Id ən də:un əlpy ðə rIvərzə:Id ən z^m do biət wi hi:lz ən tu:z ðә ljenz ən pe:ðz in nimbəl Ju:z ən brin bizəiIdz ə bigi $\int \mathrm{nt}$ əv a:l ठər t fildərn ठət kən trpt əvlpkən (h)wər ðə fansi fjeər Iz hiər ət mæidən nju:tən

If ju: Sud gu: təde: əvuər ə t $\mathrm{t}$ Ilfru:m hə:us ər də:unfru:m duər ər framptənz pa:rkzə:Id ro: ar luk dru: kwə:Iət raksa:lz slo:pi nuk ər عlbə(r)strittıd katstok dəiun b(ə:)I ka:səlhılz kuəldwindıd krə:un ən zi: If vo:k bi: ail ot huəm jəd və:In(d) əm ə:ut ðe: bi: əkım ə:ut hıðər (h)wər ðə fansi fjeər IZ pn ət mæidən njuitən 
Come, young men, come, an' here you'll vind A gift to please a maïden's mind;

Come, husbands, here be gifts to please

Your wives, an' meäke em smile vor days;

Come, so's, an' buy at Fancy Feäir

A keepseäke vor your friends elsewhere;

You can't but stop an' spend a cwein

Wi' leädies that ha' goods so fine;

An' all to meäke, vor childern's seäke, The School at Maïden Newton. 
kım j $\wedge$ y men kım ən hiər jəl və:In(d) ə gIft tə ple:z ə mæIdənz mə:In(d) kım h $\wedge z b ə n(d) z$ hiər bi: gifts to ple:z jər wə:Ivz ən mjek əm sməril vər de:z kım so:z ən bə:I ot fansi fjeər ə ki(:)psjek vər jər fren(d)z عls(h)weər jə ke:nt bət stpp ən $\operatorname{sp\varepsilon n(d)~ə~kwə:In~}$ wi ljediz ðət hə gudz sə fə:In ən a:l tə mjek vər t fildərnz sjek ðə sku:l ət mæıdən nju:tən 
ABOvE the leafless hazzle-wride

The wind-drove rain did quickly vall, An' on the meäple's ribby zide

Did hang the raïn-drop's quiv'rèn ball;

Out where the brook o' foamy yollow

Roll'd along the meäd's deep hollow,

An' noo birds wer out to beät,

Wi' flappèn wings, the vleèn wet

flying

O' zunless clouds on flow'rless ground.

How time do bring the seasons round!

The moss, a-beät vrom trees, did lie

Upon the ground in ashen droves, An' western wind did huffle high,

Above the sheds' quick-drippèn oves.

ash-wood

blow in gusts

eaves

An' where the ruslèn straw did sound

So dry, a-shelter'd in the lew,

shelter

I staïed alwone, an' weather-bound,

An' thought on times, long years agoo,

Wi' water-floods on flow'rless ground.

How time do bring the seasons round!

We then, in childhood plaÿ, did seem

In work o' men to teäke a peärt,

A-drevèn on our wild bwoy team,

driving

Or lwoadèn o' the tiny cart.

Or, on our little refters, spread

The zedgen ruf above our head,

roof of sedges

But coulden tell, as now we can,

Where each would goo to tweil a man.

toil

O jaÿs a-lost, an' jaÿs a-vound,

joys

How Providence do bring things round! 
ðı⿰z də kım rə:un(d)

əbムv ðə li:flıs hazəlrə:Id

ðə winddro:v ræın did kwıkli va:l ən pn ðə mjepəlz ribi zə:Id

did hay ðə ræindraps kwivrən ba:l ə:ut (h)wər ðə bruk ə fo:mi jalər ro:ld əlpy ðə miədz di:p hplər ən nu: bə:rdz wər ə:ut to bjet wi flapən winz ðə vliiən wet ə zムnlıs klərudz pn flə:uərlıs grə:un(d) hə:u tə:Im də brın ðə si:zənz rə:un(d)

ðə mps əbiət vrəm tri:z did lə:I әppn ðə grə:un(d) In a aən dro:vz ən westərn win(d) did h^fəl hə:I əb $\Lambda$ v ðə $\int \varepsilon d z$ kwikdripən o:vz ən (h)wər ðə r $\Lambda$ slən stre: did sə:un(d) sə drə:I ə⿻上丨tərd In ðə lu: ə:I stæId əluən ən weðərbərun(d) ən ठว:t pn tə:Imz lpy jiərz əgu: wi wo:tərflıdz pn flə:uərlıs grə:un(d) hə:u tə:Im də brın ðə si:zənz rə:un(d)

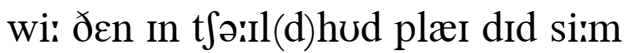
In wərrk a men to tjek ə pjairt ədre:vən pn ə:uər wə:Il(d) bwə:I ti:m ər luədən ə ðə tə:Ini ka:rt ar pn ə:uər litəl re:ftərz spred

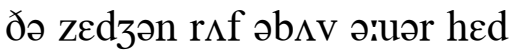
bət kudən tعl əz nə:u wi: kan (h)wər itt $\int$ wud gu: tə twəril ə man o: dzæIz əlpst ən dzæIz əvə:un(d) hə:u providəns də brin ðınz rə:un(d) 
Where woonce along the sky o' blue

The zun went roun' his longsome bow, $\operatorname{arc}$ An' brighten'd, to my soul, the view

About our little farm below,

There I did plaÿ the merry geäme,

Wi' childern ev'ry holitide,

But coulden tell the vaïce or neäme

That time would vind to be my bride.

$\mathrm{O}$ hwome a-left, $\mathrm{O}$ wife a-vound,

How Providence do bring things round!

An' when I took my manhood's pleäce,

A husband to a wife's true vow,

I never thought by neäme or feäce

O' childern that be round me now.

An' now they all do grow vrom small,

Drough life's feäir sheäpes to big an' tall,

I still be blind to God's good plan,

To pleäce em out as wife, or man.

O thread o' love by God unwound,

How $\mathrm{He}$ in time do bring things round! 
(h)wər (w)u:ns əlpy ðə skə:ı ə blu:

ðə zムn went rə:un (h)Iz lpysəm bo:

ən brə:Itənd to mə:I so:l ठə vju:

əbə:ut ə:uər litəl fa:rm bilo:

ðər ə:I did plæı ðə meri gjem

wi tfrldərn عvri ho:litə:Id

bət kudən tعl ðə væIS ər njem

ðət tə:Im wud və:In(d) tə bi: mə:I brə:Id

o: huəm əleft o: wə:If əvə:un(d)

hə:u providəns də brin ðınz rə:un(d)

ən (h)wen ə:I tuk mə:I manhudz pljes

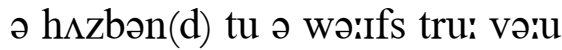

ว:I nevər ðo:t b(ə:)I njem ər fjes

ə t fildərn ðət bi: rə:un(d) mi: nə:u

ən nə:u ðе: a:l də gro: vrəm sma:l

dru: lə:Ifs fjeər $\int j \varepsilon p s$ to big ən ta:l

ə:I strl bi: blə:In(d) to godz gud plan

tə pljes əm ə:ut əz wə:If ər man

o: dred ə $1 \Lambda \mathrm{v} b(\partial:)$ I gpd $\Lambda$ nwərun(d)

hə:u hi: In tə:Im də brin ðınz rə:un(d) 
WELL, aye, last evenèn, as I shook

My locks ov haÿ by Leecombe brook,

The yollow zun did weakly glance

Upon the winter meäd askance,

A-castèn out my narrow sheäde

Athirt the brook, an' on the meäd.

shadow

across

The while ageän my lwonesome ears

Did russle weatherbeäten spears,

Below the withy's leafless head

willow's

That overhung the river's bed;

I there did think o' days that dried

The new-mow'd grass o' zummer-tide,

When white-sleev'd mowers' whetted bleädes

Rung sh'ill along the green-bough'd gleädes,

clearly

An' maïdens gaÿ, wi' plaÿsome chaps,

A-zot wi' dinners in their laps,

siting down

Did talk wi' merry words that rung

Around the ring, vrom tongue to tongue;

An' welcome, when the leaves ha' died,

Be zummer thoughts in winter-tide. 
z^mər ð๖:ts In wintər tə:Im

wel æi le:st iivmən əz ə:I Juk

mə:I lpks əv hæi b(ə:)I li:ku:m bruk

ðə jalər z^n did wi:kli gle:ns

əppn ðə wintər miəd əske:ns

əka:stən ə:ut mə:I narə(r) $\int j \varepsilon d$

əðə:rt ðə bruk ən pn ðə mjed

ðə (h)wə:Il əgjen mə: luənsəm iərz

did rısəl weðərbiətən spiərz

bılo: ðə wıðiz liiflıs hed

ðət ว:vərh^y ðə rivərz bed

ə:I ðər did ðınk ə de:z ðət drə:Id

ðə nju: mo:d gra:s ə zımərtə:Id

(h)wen (h)wəitsliivd mo:ərz (h)wetıd bljedz

rıy $\int \mathrm{Il}$ əlpy ðə gri:nbə:ud gljedz

ən mæIdənz gæi wi plæısəm t $\int a p s$

əzat wi dinərz in ðər laps

did te:k wi meri wərrdz ðət r $\wedge$ y

ərə:un(d) ठə rin vrəm t $\Lambda$ y tə t $\Lambda$ y

ən welkəm (h)wen ðə liivz hə də:Id

bi: zımər ðo:ts In wintərtə:Id 
I'M out, when, in the Winter's blast,

The zun, a-runnèn lowly round,

Do mark the sheädes the hedge do cast

shadows

At noon, in hoarvrost, on the ground.

I'm out when snow's a-lyèn white

In keen-aïr'd vields that I do pass,

An' moonbeams, vrom above, do smite

On ice an' sleeper's window-glass.

I'm out o' door,

When win' do zweep,

By hangèn steep,

Or hollow deep,

slope

At Lindenore.

O welcome is the lewth a-vound

shelter

By rustlèn copse, or ivied bank,

Or by the haÿ-rick, weather-brown'd

By barken-grass, a-springèn rank;

farmyard-

Or where the waggon, vrom the team

A-freed, is well a-housed vrom wet,

An' on the dousty cart-house beam

dusty

Do hang the cobweb's white-lin'd net.

While storms do roar,

An' win' do zweep,

By hangèn steep,

Or hollow deep,

At Lindenore.

An' when a good day's work 's a-done

An' I do rest, the while a squall

Do rumble in the hollow tun,

chimney

An' ivy-stems do whip the wall, 
ə:Im ə'ut ə duər

ə:Im ərut (h)wen In ðə wintərz bla:st

ðə z^n ər^nən lo:li rə'un(d)

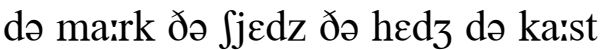

ət nuin in huərvrost pn ðə grə:un(d)

ว:Im ə:ut (h)wen sno:z ələ:Iən (h)wə:It

In ki:næird vi:l(d)z ðət ə:I də pa:s

ən mu:nbi:mz vrəm əb $\Lambda \mathrm{v}$ də smə:It

pn ə:Is ən sli:pərz windərgla:s

ə:Im əiut ə duər

(h)wen win(d) də zwi:p

b(ə:)I hayən sti:p

ar holər di:p

at lindənuər

o: welkəm Iz ðə lu: $\theta$ əvə:und

b(ə:)I r $\Lambda$ slən kpps ar ə:Ivid bayk

ar b(ə:)I ðə hæIrık weðərbrə:und

b(ə:)I ba:rkəngra:s əsprinən rank

ar (h)wər ðə wagən vrəm ðə ti:m

əfriid Iz wel ohə:uzd vrəm wet

ən pn ðə də:usti ka:rthə:us bi:m

də hạ ðə kpbwebz (h)wə:tllə:Ind net

(h)wə:Il sta:rmz də ruər

ən $w \ln (d)$ də zwi:p

b(ə:)I hayən sti:p

ar holər di:p

at lindənuər

ən (h)wen ə gud de:z wərrks əd $\Lambda$ n

ən ə:I də rest ðə (h)wə:Il ə skwa:l

də rımbəl In ðə hplər t $\Lambda$ n

ən ə:Ivistemz də (h)wıp ðə wa:l 
Then in the house do sound about

My ears, dear vaïces vull or thin, A praÿèn vor the souls vur out At sea, an' cry wi' bibb'rèn chin-

Oh! shut the door.

What soul can sleep,

Upon the deep,

When storms do zweep

At Lindenore. 
ðعn In ðə hə:us də sərun(d) əbərut mə:I iərz diər væIsIz vul ər ðın әpræıən vər ðə so:lz və:r ə:ut at si: ən krə:I wi bibrən $\mathrm{t} \int \mathrm{m}$ o: $\int \Lambda \mathrm{t}$ ðə duər (h)wpt so:l kən sli:p әppn ðə di:p

(h)wen sta:rmz də zwi:p at lindənuər 


\section{GRIEF AN' GLADNESS}

"CAN all be still, when win's do blow?

Look down the grove an' zee

The boughs a-swingèn on the tree,

An' beäten weäves below.

Zee how the tweilèn vo'k do bend toiling folk

Upon their windward track,

Wi' ev'ry string, an' garment's end,

A-flutt'rèn at their back,"

I cried, wi' sorrow sore a-tried,

An' hung, wi' Jenny at my zide,

My head upon my breast.

Wi' strokes o' grief so hard to bear,

'Tis hard vor souls to rest.

Can all be dull, when zuns do glow?

Oh! no; look down the grove,

Where zides o' trees be bright above;

An' weäves do sheen below;

shine

An' neäked stems o' wood in hedge

Do gleäm in streäks o' light,

An' rocks do gleäre upon the ledge

O' yonder zunny height,

"No, Jeäne, wi' trials now withdrawn,

Lik' darkness at a happy dawn,"

I cried, "Noo mwore despair;

Wi' our lost peace ageän a-vound,

'Tis wrong to harbour ceäre." 
griff ən gladnis

kan a:l bi: stıl (h)wen win(d)z də blo:

luk də:un ðə gro:v ən zi:

ðə bə:uz əswinən pn ðə tri:

ən biətən wjevz bilo:

zi: hə:u ðə twə:Ilən vo:k də ben(d)

əppn ðər win(d)wərd trak

wi عvri strın ən ga:rmənts $\varepsilon n(d)$

əflıtrən ət ðər bak

ว:I krə:Id wi sarə(r) suər ətrə:Id

ən h^y wi dzeni ət mə:I zə:Id

mə:I hed əppn mə:I brest

wi stro:ks ə griff sə ha:rd to beər

tIz ha:rd vər so:lz to rest

kan a:l bi: d^l (h)wen zınz də glo:

o: no: luk də:un ðə gro:v

(h)wər zə:Idz ə tri:z bi: brə:It $ə \mathrm{~b} \Lambda \mathrm{v}$

ən wjevz də Siin bilo:

ən njekıd stemz ə wud in hedz

də gliəm in striəks ə lə:It

ən roks də gljeər əppn ðə ledz

ə jandər zムni hə:It

no: dzjen wi trə:ıəlz nə:u wıðdre:n

lik da:rknis ət ə hapi de:n

ə:I krə:Id nu: muər dispeər

wi ə:uər lost pi:s əgjen əvə:un(d)

tIz ron to ha:rbər kjeər 


\section{SLIDÈN}

WHEN wind wer keen,

Where ivy-green

Did clwosely wind

Roun' woak-tree rind, oak-tree bark

An' ice shone bright,

An' meäds wer white, wi' thin-spread snow

Then on the pond, a-spreadèn wide,

We bwoys did zweep along the slide, A-strikèn on in merry row.

There ruddÿ-feäced,

In busy heäste,

We all did wag

move

A spankèn lag,

To win good speed,

When we, straight-knee'd, wi' foreright tooes,

pointing straight forward

Should shoot along the slipp'ry track,

Wi' grindèn sound, a-gettèn slack,

The slower went our clumpèn shoes.

Vor zome slow chap,

Did teäke mishap,

As he did veel

His hinder heel

A-het a thump,

Wi' zome big lump, o' voot an' shoe.

Down vell the voremost wi' a squall,

An' down the next went wi' a sprawl, An' down went all the laughèn crew. 
slə:Idən

(h)wen win(d) wər ki:n

(h)wər ə:Ivigri:n

did kluəsli wə:In(d)

rə:un (w)uəktri: rə:In(d)

ən ə:Is $\int \mathrm{pn}$ brə:It

ən miədz wər (h)wə:It wi ðInspred sno:

ðદn pn ðə ppn(d) əspredən wə:Id

wi: bwə:Iz did zwi:p əlpy ðə slə:Id

əstrikən pn In meri ro:

ðər r $\wedge$ difjest

In bizi hjest

wi: a:l did wag

ə spankən lag

to win gud spid

(h)wen wi: stræitni:d wi vuərrə:It tu:z

Sud Sut əlpy ðə slipri trak

wi grə:In(d)ən sə:un(d) əgetən slak

ðə slo:ər went ə:uər klımpən Ju:z

vər zım slo: t fap

did tjek mishap

əz hi: did vi:l

(h)Iz hə:Indər hi:l

əhet ə $\theta \Lambda \mathrm{mp}$

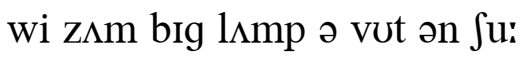

dərun vel ðə vuərmo:st wi ə skwa:l

ən də:un ðə neks(t) went wi ə spra:l

ən də:un went a:l ðə le:fən kru: 
As to an' fro,

In merry row,

We all went round

On ice, on ground

The maïdens nigh

A-stannèn shy, did zee us slide,

An' in their eäprons small, did vwold

fold

Their little hands, a-got red-cwold,

Or slide on ice o' two veet wide.

By leafless copse,

An' beäre tree-tops,

bare

An' zun's low beams,

An' ice-boun' streams,

An' vrost-boun' mill,

A-stannèn still, come wind, blow on,

An' gi'e the bwoys, this Chris'mas tide,

give

The glitt'rèn ice to meäke a slide,

As we had our slide, years agone. 
az tu: on fro:

In meri ro:

wi: a:l went rə:un(d)

pn ə:Is pn grə:un(d)

ðə mæIdənz nə:I

əstanən SəII did zi: əs slə:Id

ən In ठər jepərnz sma:l did vuəld

ðər litəl han(d)z əgpt redkuəld

ar slə:Id pn ə:Is ə tu: vi:t wə:Id

b(ə:)I li:flıs kpps

ən bjeər tri:tpps

ən zınz lo: bi:mz

ən ə:Isbə:un stri:mz

on $\operatorname{vrns}(\mathrm{t})$ bərun mil

əstanən stil k^m win(d) blo: pn

ən gi: ðə bwə:Iz ठıs krisməs tə:Id

ðə glitrən ə:Is tə mjek ə slə:Id

əz wi: had ə:uər slə:Id jiərz əgpn 


\section{LWONESOMENESS}

As I do zew, wi' nimble hand,

In here avore the window's light,

How still do all the housegear stand

Around my lwonesome zight.

How still do all the housegear stand

Since Willie now 've a-left the land.

The rwose-tree's window-sheädèn bow

$\operatorname{arch}$

Do hang in leaf, an' win'-blow'd flow'rs,

Avore my lwonesome eyes do show

Theäse bright November hours.

these

Avore my lwonesome eyes do show

Wi' nwone but I to zee em blow.

The sheädes o' leafy buds, avore shadows

The peänes, do sheäke upon the glass,

An' stir in light upon the vloor,

Where now vew veet do pass,

An' stir in light upon the vloor,

Where there's a-stirrèn nothèn mwore.

This win' mid dreve upon the maïn, may drive

My brother's ship, a-plowèn foam,

But not bring mother, cwold, nor raïn,

At her now happy hwome.

But not bring mother, cwold, nor rain,

Where she is out o' païn.

Zoo now that I'm a-mwopèn dumb,

A-keepèn father's house, do you

Come of en wi' your work vrom hwome,

Vor company. Now do. 
luənsənmnis

az ə:I də zo: wi nimbəl han(d)

In hiər əvuər ðə windərz lə:It

hə:u strl du: a:l ðə hə:usgiər $\operatorname{stan}(\mathrm{d})$

ərə:un(d) mə:I luənsəm zə:It

hə;u strl du: a:l ठə hə:usgiər $\operatorname{stan}(\mathrm{d})$

sins wıli nə:u v əleft ðə lan(d)

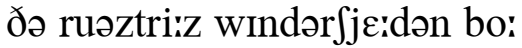

də hay In li:f ən winblo:d flə:uərz

əvuər mə:I luənsəm ə:Iz də So:

ðiəz brə:It no:vembər ə:uərz

əvuər mə:I luənsəm ə:Iz də אo:

wi nuən bət ə:I to zi: əm blo:

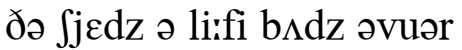

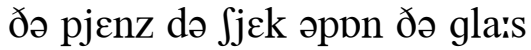

ən stə:r In lə:It əppn ðə vluər

(h)wər nə:u vju: vi:t də pais

ən stə:r In lə:it əppn ðə vluər

(h)wər ðərz əstərrən n $\Lambda$ Өən muər

ðIs wIn(d) mId dre:v əppn ðə mæIn

mə:I br^ðərz $\int \mathrm{p} p$ əplə:uən fo:m

bət npt brin m^ðər kuəld nar ræIn

ət (h)ər nə:u hapi huəm

bət npt brin m^ðər kuəld nər ræın

(h)wər fi: iz ə:ut ə pæin

zu: nə:u ðət ə:Im əmuəpən $\mathrm{d} \Lambda \mathrm{m}$

əki(:)pən fe:ðərz hə:us də ju:

kım pfən wi jər wərrk vrəm huəm

vər kımpəni nə:u du: 
Come of en wi' your work vrom hwome, Up here a-while. Do come. 
kım pfən wi jər wərrk vrəm huəm $\Lambda \mathrm{p}$ hiər ə(h)wə:Il du: kım 
'TwER at night, an' a keen win' did blow

Vrom the east under peäle-twinklèn stars,

All a-zweepèn along the white snow;

On the groun', on the trees, on the bars,

Vrom the hedge where the win' russled drough,

There a light-russlèn snow-doust did vall;

through

An' noo pleäce wer a-vound that wer lew,

But the shed, or the ivy-hung wall.

Then I knock'd at the wold passage door

old

Wi' the win'-driven snow on my locks;

Till, a-comèn along the cwold vloor,

There my Jenny soon answer'd my knocks.

Then the wind, by the door a-swung wide,

Flung some snow in her clear-bloomèn feäce,

An' she blink'd wi' her head all a-zide,

An' a-chucklèn, went back to her pleäce.

An' in there, as we zot roun' the brands,

sat, fire

Though the talkers wer maïnly the men,

Bloomèn Jeäne, wi' her work in her hands,

Did put in a good word now an' then.

An' when I took my leave, though so bleäk

Wer the weather, she went to the door,

Wi' a smile, an' a blush on the cheäk

That the snow had a-smitten avore. 
ว sno:i nə:It

twər ət nə:It ən ə ki:n win(d) did blo:

vrəm ði isst $\Lambda$ ndər pjeltwınklən sta:rz

a:l əzwi:pən əlpy ðə (h)wə:It sno:

pn ðə grə:un(d) pn ðə tri:z pn ðə ba:rz

vrəm ðə hed3 (h)wər ðə win(d) r rssəld dru:

ðər ə lə:itrıslən sno:də:ust did va:l

ən nu: pljes wər əvə:un(d) ðət wər lu:

bət ðə $\int \varepsilon d$ ar ठi ə:Ivihıy wa:l

ðعn ə:I npkt ət ðə (w)uəld pasid3 duər

wi ðə windrıvən sno: pn mə: lpks

til əkımən əlpy ðə kuəld vluər

ðər mə:I dzદni su:n ع:nsərd mə:I noks

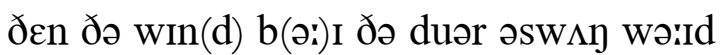

flıy səm sno: in (h)ər kliərblu:mən fjes

ən Si: blinkt wi (h)ər hed ail əzə:Id

ən ət $\int \Lambda k l ə n$ went bak tu (h) ər pljes

ən In ðعər əz wi: zat rə:un ðə bran $(\mathrm{d}) \mathrm{z}$

ðо: ðə te:kərz wər mæınli ðə men

blu:mən dzjen wi (h)ər wə:rk in (h)ər han(d)z

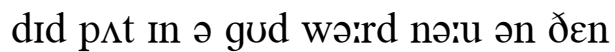

ən (h)wen ə:I tuk mə:ı li:v ðo: sə bliək

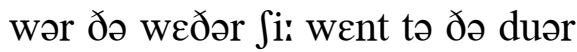

wi ə smə:ıl ən ə bl $\Lambda \int$ pn ðə t $f i ə k$

ðət ðə sno: had əsmitən əvuər 
WE zot bezide the leäfy wall,

Upon the bench at evenfall,

While aunt led off our minds vrom ceäre

Wi' veäiry teäles, I can't tell where:

An' vound us woone among her stock

O' feäbles, o' the girt Year-clock.

His feäce wer blue's the zummer skies, An' wide's the zight o' lookèn eyes, For hands, a zun wi' glowèn feäce, An' peäler moon wi' swifter peäce, Did wheel by stars o' twinklèn light, By bright-wall'd day, an' dark-treed night; An' down upon the high-sky'd land, A-reachèn wide, on either hand, Wer hill an' dell wi' win'-swaÿ'd trees, An' lights a-zweepèn over seas, An' gleamèn cliffs, an' bright-wall'd tow'rs, Wi' sheädes a-markèn on the hours;

An' as the feäce, a-rollèn round, Brought comely sheäpes along the ground, The Spring did come in winsome steäte Below a glowèn raïnbow geäte; An' fan wi' airr a-blowèn weak, Her glossy heäir, an' rwosy cheäk, As she did shed vrom oben hand, The leäpèn zeed on vurrow'd land;

The while the rook, wi' heästy flight, A-floatèn in the glowèn light, Did bear avore her glossy breast A stick to build her lofty nest, 
ðə jiərklpk

wi: zat bızə:Id ðə li:fi wa:l

əppn ðə bent $\int$ ət iivənfa:l

(h)wə:ıl ع:nt led pf ə:uər mə:In(d)z vrəm kjeər

wi vjeəri tjelz ə:I ke:nt tel (h)weər

ən və:un(d) əs (w)u:n əmpy (h)ər stpk

ə fjebəlz ə ðə gə:rt jiərklpk

(h)Iz fjes wər blu:z ðə z^mər skə:Iz

ən wə:Idz ðə zə:It ə lukən ə:Iz

vər han(d)z ə zın wi glo:ən fjes

ən pjelər mu:n wi swiftər pjes

did (h)will b(ə:)I sta:rz ə twinklən lə:it

b(ə:)I brə:Itwa:ld de: ən da:rktri:d nə:It

ən də:un əppn ðə hə:Iskə:Id lan(d)

əri:tfən wə:Id pn ə:Iðər han(d)

wər hil ən del wi winswæid tri:z

ən lə:tts əzwi:pən o:vər si:z

ən gli:mən klıfs ən brə:Itwa:ld tə:uərz

wi $\int j \varepsilon d z$ əma:rkən pn ði əruərz

ən az ðə fjes əro:lən rə:un(d)

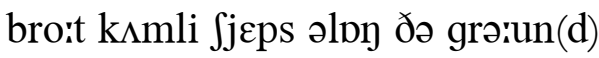

ðə sprin did kım in winsəm stjet

bilo: a glo:ən ræinbo: gjet

ən fan wi æIr əblo:ən wi:k

(h)ər glpsi hjeər ən ruəzi t fiək

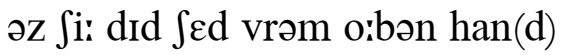

бә liəpən zi:d pn v $\Lambda$ rə(r)d lan(d)

ðə (h)wə:Il ðə ruk wi hjesti flə:It

əflo:tən in ðə glo:ən lə:it

did beər əvuər (h)ər glpsi brest

ə strk to bild (h)ər lofti nest 
An' strong-limb'd Tweil, wi' steady hands,

Did guide along the vallow lands

The heavy zull, wi' bright-sheär'd beam,

Avore the weary oxen team.

Wi' Spring a-gone there come behind

Sweet Zummer, jaÿ ov ev'ry mind,

Wi' feäce a-beamèn to beguile

Our weary souls ov ev'ry tweil.

While birds did warble in the dell

In softest air o' sweetest smell;

An' she, so winsome-feäir did vwold

Her comely limbs in green an' goold,

An' wear a rwosy wreath, wi' studs

O' berries green, an' new-born buds,

A-fring'd in colours vier-bright,

Wi' sheäpes o' buttervlees in flight.

When Zummer went, the next ov all

Did come the sheäpe o' brown-feäc'd Fall,

A-smilèn in a comely gown

O' green, a-shot wi' yellow-brown,

A-border'd wi' a goolden stripe

O' fringe, a-meäde o' corn-ears ripe,

An' up ageän her comely zide,

Upon her rounded eärm, did ride

arm

A perty basket, all a-twin'd

O' slender stems wi' leaves an' rind, A-vill'd wi' fruit the trees did shed, All ripe, in purple, goold, an' red; An' busy Leäbor there did come A-zingèn zongs ov harvest hwome, An' red-ear'd dogs did briskly run Roun' cheervul Leisure wi' his gun, Or stan' an' mark, wi' stedvast zight, The speckled pa'tridge rise in flight. 
ən stroylimd twə:Il wi stedi han (d)z did gə:Id əlpy ðə valə(r) lan(d)z

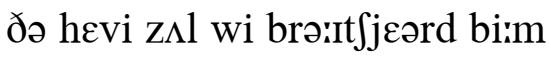
əvuər ðə wiəri pksən ti:m wi sprıy əgpn ðər kım bihə:In(d) swi(:)t z^mər dzæı əv عvri mə:In(d) wi fjes əbi:mən to bigə:il ə:uər wiəri so:lz əv عvri twə:Il (h)wə:Il bə:rdz did wa:rbəl In ðə del In spftıst æir ə swi(i)tıst smel ən fi: sə winsəmfjeər did vuəld (h)ər kımli limz in gri:n ən gu:ld ən weər ə ruəzi ri: $\theta$ wi st $\Lambda \mathrm{dz}$ ə beriz gri:n ən nju:ba:rn b $\mathrm{dz}$ əfrindzd In k^lərz və:Iərbrə:It

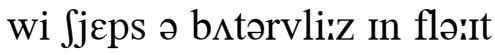
(h)wen zムmər went ðə neks(t) əv a:l

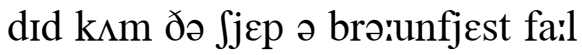
əsmə:Ilən In ə kımli gə:un ə gri:n əshpt wi jalərbrə:un əba:rdərd wi ə guildən strə:Ip ə frindz əmjed ə karniərz rə:ıp ən $\Lambda$ p əgjen (h)ər kımli zə:Id əppn (h)ər rə:undid ja:rm did rə:Id ə pərrti baiskit ail ətwə:In(d) ə slendər stemz wi liivz ən rə:In(d) əvild wi fruit ðə tri:z did $\int \varepsilon d$ a:l rə:Ip in pərrpəl guild ən red ən bızi ljєbər ðər dıd kım əzIngən zpyz əv ha:rvist huəm ən rediord dpgz did briskli r $\wedge n$ rə:un tfiərvul lezər wi (h)Iz g^n ar stan ən ma:rk wi stedvaist zəit ðə spekəld pe:trid3 rə:Iz in flə:It 
An' next ageän to mild-feäc'd Fall Did come peäle Winter, last ov all, A-bendèn down, in thoughtvul mood, Her head 'ithin a snow-white hood A-deck'd wi' icy-jewels, bright An' cwold as twinklèn stars o' night; An' there wer weary Leäbor, slack O' veet to keep her vrozen track, A-lookèn off, wi' wistful eyes, To reefs o' smoke, that there did rise A-meltèn to the peäle-feäc'd zun, Above the houses' lofty tun.

An' there the girt Year-clock did goo great

By day an' night, vor ever true,

Wi' mighty wheels a-rollèn round

'Ithout a beät, 'ithout a sound. 
ən neks(t) əgjen tə mə:Il(d)fjest fa:l did kım pjel wintər le:st əv a:l əbendən də:un in $\theta$ s:tvul mud (h)ər hed ıðın ə sno:(h)wə:It hud ədekt wi ə:Isi dzurəlz brə:It ən kuəld əz twinklən sta:rz ə nə:It ən ðər wər wiəri ljebər slak ə vi:t to ki(:)p (h)ər vro:zən trak əlukən pf wi wistful ə:Iz tə ri:fs ə smo:k ðət ðər did rə:IZ əmeltən tə ठə pjelfjest $\mathrm{z} \Lambda \mathrm{n}$ əb $\Lambda$ v ðə hə:uzIz lpfti t $\Lambda$ n ən ðər ðə gə:rt jiərklpk did gu: b(ə:)I de: ən nəit vər عvər tru: wi məriti (h)willz əro:lən rə:un(d) ıðə:ut ə biət Іðə:ut ə sə:un(d) 
No, no, why you've noo wife at hwome

Abidèn up till you do come,

Zoo leäve your hat upon the pin, so, peg

Vor I'm your waïter. Here's your inn,

Wi' chair to rest, an' bed to roost;

You have but little work to do

This vrosty time at hwome in mill, Your vrozen wheel's a-stannèn still, The sleepèn ice woont grind vor you.

No, no, you woont goo hwome to-night,

Good Robin White, o' Craglin mill.

As I come by, to-day, where stood

Wi' neäked trees, the purple wood,

The scarlet hunter's ho'ses veet

Tore up the sheäkèn ground, wind-fleet,

Wi' reachèn heads, an' pankèn hides;

as swift as wind

The while the flat-wing'd rooks in vlock, panting

Did zwim a-sheenèn at their height; shining

But your good river, since last night,

Wer all a-vroze so still's a rock.

No, no, you woont goo hwome to-night,

Good Robin White, o' Craglin mill.

Zee how the hufflèn win' do blow, gusty

A-whirlèn down the giddy snow:

Zee how the sky's a-weärèn dim,

Behind the elem's neäked lim'

That there do leän above the leäne;

Zoo teäke your pleäce bezide the dogs, so, fire-dogs

An' sip a drop o' hwome-brew'd eäle, ale

An' zing your zong or tell your teäle,

While I do bait the vier wi' logs. stoke, fire 
not gu: huəm tənə:It

no: no: (h)wə:I jəv nu: wə:If ət huəm

əbə:Idən $\Lambda$ p tıl ju: də k $\Lambda \mathrm{m}$

zu: liəv jər hat əppn ðə pin

var ə:Im jər wæitər hiərz jər in

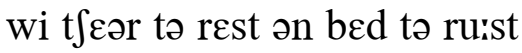

jə hav bət litəl wərrk to du:

ðIs vrosti tə:Im ot huəm in mil

jər vro:zən (h)wi:lz əstanən stıl

ðə sli:pən ə:Is wu(:)nt grə:In(d) vər ju:

no: no: jə wu(:)nt gu: huəm tənə:it

gud robin (h)wə:It ə kraglın mil

az ə:I kım b(ə:)I təde: (h)wər stud

wi njekıd tri:z ðə pərrpəl wud

ðə skarrlit hıntərz hpsiz vi:t

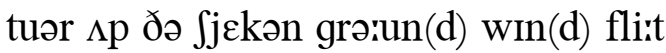

wi ritt〕n hedz ən paykən hə:Idz

ðə (h)wə:Il ðə flat wingd ruks in vlpk

did zwim ə⿻i:nən ət ðər hə:It

bət ju(:)ər gud rivər sins le:s(t) nə:It

wər a:l əvro:z sə stilz ə rok

no: no: jə wu(:)nt gu: huəm tənə:It

gud robin (h)wə:It ə kraglin mil

zi: hə:u ðə h^flən win(d) də blo:

ə(h)wə:r(d)lən də:un ðə gidi sno:

zi: hə:u ðə skə:Iz əwعərən dim

bihə:In(d) ði عləmz njekıd lim

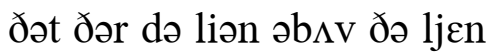

zu: tjek jər pljes bizə:Id ðə dpgz

ən sip ə drap ə huəm bru:d jel

ən zin jər zpy ar tel jər tjel

(h)wə:Il ə:I də bæit ðə və:ıər wi lpgz 
No, no, you woont goo hwome to-night,

Good Robin White, o' Craglin mill.

Your meäre's in steäble wi' her hocks

In straw above her vetterlocks,

A-reachèn up her meäney neck,

An' pullèn down good haÿ vrom reck,

covered with mane

A-meäkèn slight o' snow an' sleet;

She don't want you upon her back,

To vall upon the slippery stwones

On Hollyhill, an' break your bwones,

Or miss, in snow, her hidden track.

No, no, you woont goo hwome to-night,

Good Robin White, o' Craglin mill.

Here, Jenny, come pull out your key

An' hansel, wi' zome tidy tea,

The zilver pot that we do owe

To your prize butter at the show,

An' put zome bread upon the bwoard.

Ah! he do smile; now that 'ull do,

He'll staÿ. Here, Polly, bring a light,

We'll have a happy hour to-night,

I'm thankvul we be in the lew.

shelter

No, no, he woont goo hwome to-night,

Not Robin White, o' Craglin mill. 
no: no: jə wu(:)nt gu: huəm tənə:It gud robin (h)wə:It ə kraglin mil

jər mjeərz In stjebəl wi (h)ər hoks In stre: əb $\Lambda \mathrm{v}$ (h)ər vetərlpks

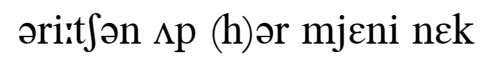
ən pulən də:un gud hæi vrəm rek əmjદkən slə:t ə sno: ən sli:t fi: do:nt wont ju: əppn (h)ər bak tə va:l əppn ðə slipri stuənz pn hpli hil ən bre:k jər buənz ar mis In sno: (h)ər hidən trak no: no: jə wu(:)nt gu: huəm tənə:It gud robin (h)wə:It ə kraglın mil

hiər dzeni kım pul ə:ut jər ke: ən hansəl wi zəm tə:Idi te: ðə zIlvər ppt ðət wi: də o:

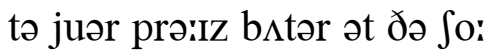
ən p $\Lambda$ t zəm bred əppn ðə buərd a: hi: də smə:Il nə:u ðat ul du: hi:l stæı hiər ppli brin ə lə:it wi:l hav ə hapi əuuər tənə:It ə:Im $\theta$ ankvol wi: bi: In ðə lu: no: no: hi: wu(:)nt gu: huəm tənə:It not robin (h)wə:It a kraglın mil 


\section{THE HUMSTRUM}

WHY woonce, at Chris'mas-tide, avore once

The wold year wer a-reckon'd out, old

The humstrums here did come about, A-soundèn up at ev'ry door.

But now a bow do never screäpe

A humstrum, any where all round, An' zome can't tell a humstrum's sheäpe,

An' never heärd his jinglèn sound.

As ing-an-ing did ring the string,

As ang-an-ang the wires did clang.

The strings a-tighten'd lik' to crack

Athirt the canister's tin zide,

Did reach, a glitt'rèn, zide by zide, Above the humstrum's hollow back. An' there the bwoy, wi' bended stick, A-strung wi' heäir, to meäke a bow,

Did dreve his elbow, light'nèn quick,

Athirt the strings from high to low.

As ing-an-ing did ring the string,

As ang-an-ang the wires did clang.

The mother there did stan' an' hush

Her child, to hear the jinglèn sound,

The merry maïd, a-scrubbèn round

Her white-steäv'd pail, did stop her brush.

-hooped

The mis'ess there, vor wold time's seäke,

Had gifts to gi'e, and smiles to show, give

An' meäster, too, did stan' an' sheäke

His two broad zides, a-chucklèn low,

While ing-an-ing did ring the string,

While ang-an-ang the wires did clang. 
ðə h^mstrım

(h)wə:I (w)u:ns ət krisməstə:Id əvuər

ðə (w)uəld jiər wər ərekənd ərut

ðə hımstrımz hiər did kım əbərut

əsə'un(d)ən $\Lambda \mathrm{p}$ ət $\varepsilon v r i$ duər

bət nə:u ə bo: də nevər skrjep

ə h^mstrım عni (h)wər a:l rə:un(d)

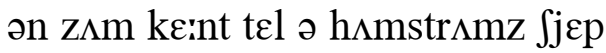

ən nevər hiərd (h)Iz dzInglən sə:un(d)

əZ Inənıy dıd rı刀 ðə strıy

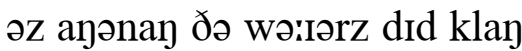

ðə strinz ətə:itənd lik to krak

əðə:rt ðə kanistərz tın zə:Id

did riits a glitrən zə:Id b(ə:)I zə:Id

əbıv ðə hımstrımz hplər bak

ən ðər ðə bwə:I wi bendid stık

əstrıy wi hjeər to mjek ə bo:

did dre:v (h)Iz عlbo: lə:Itnən kwik

əðə:rt ðə strinz vrəm hə:I tə lo:

əz Inənın dıd rıy ðə strin

əz ayənaך ðə wә:ıərz did klaך

ðə m^ðər ðعər did stan ən $\mathrm{h} \Lambda \int$

(h)ər tfəril(d) tə hiər ðə dzInglən sə:un(d)

ðə meri mæId əskrıbən rə:un(d)

(h)ər (h)wəitstjevd pæil did stpp (h)ər br $\Lambda \int$

ðə misis ðعər vər (w)uəld tə:Imz sjek

had gifts to gi: ən(d) smə:ilz to fo:

ən mja:stər tu: did stan ən $\int j \varepsilon k$

(h)Iz tu: bro:d zə:Idz ət $\Lambda \Lambda k l ə n$ lo:

(h)wə:ıl Inənın did rın ðə strın

(h)wə:Il ayənay ðə wə:ıərz did klay 
The plaÿers' pockets wer a-strout, stretched out Wi' wold brown pence, a-rottlèn in, Their zwangèn bags did soon begin, swinging violently Wi' brocks an' scraps, to plim well out. The childern all did run an' poke Their heads vrom hatch or door, an' shout A-runnèn back to wolder vo'k. wicket-gate

Why, here! the humstrums be about! As ing-an-ing did ring the string, As ang-an-ang the wires did clang. 
ðə plæıərz ppkits wər əstrə:ut wi (w)uəld brə:un pens ərptlən in ðər zwayən bagz did su:n bigin wi broks ən skraps to plim wel ərut ðə tfildərn a:l did rın ən po:k ðər hedz vrəm hat $\int$ ər duər ən Sə:ut ərınən bak to (w)uəldər vo:k

(h)wə:I hiər ðə h^mstrımz bi: əbə:ut əz Ijənın did rıy ðə strin əz ayənay ðə wə:ıərz did klay 
SHAFTESBURY FEÄIR

WHEN hillborne Paladore did show

So bright to me down miles below,

As woonce the zun, a-rollèn west, once

Did brighten up his hill's high breast, its

Wi' walls a-lookèn dazzlèn white,

Or yollow, on the grey-topp'd height

Of Paladore, as peäle day wore Awaÿ so feäir,

Oh! how I wish'd that I wer there.

The pleäce wer too vur off to spy

The livèn vo'k a-passèn by;

The vo'k too vur vor aïr to bring

The words that they did speak or zing.

All dum' to me wer each abode,

An' empty wer the down-hill road

Vrom Paladore, as peäle day wore Awaÿ so feäir;

But how I wish'd that I wer there.

But when I clomb the lofty ground climbed

Where livèn veet an' tongues did sound, At feäir, bezide your bloomèn feäce, The pertiest in all the pleäce, As you did look, wi' eyes as blue As yonder southern hills in view, Vrom Paladore-O Polly dear, Wi' you up there,

How merry then wer I at feäir. 
Sa:sbri fjeər

(h)wen hilba:rn paləduər did So:

sə brə:It tə mi: də:un mə:ilz bilo:

əz (w)u:ns ðə z^n əro:lən west

did brə:Itən $\Lambda p$ (h)Iz hilz hə:I brest

wi wa:lz əlukən dazlən (h)wə:It

ar jalər pn ðə gre:tppt hə:It

əv paləduər əz pjel de: wuər วพə:I sə fjeər

o: hə:u ə:I wISt ðət ə:I wər ðعər

ðə pljes wər tu: vərr pf to spə:I

ðə livən vo:k əpa:sən bə:I

ðə vo:k tu: və:r vər æIr to brın

ðə wə:rdz ðət ðе: did spi:k ər zIy

a:l d $\Lambda \mathrm{m}$ tə mi: wər iit $\int$ obo:d

ən $\varepsilon \mathrm{m}(\mathrm{p}) \mathrm{ti}$ wər ðə də'unhıl ro:d

vrəm paləduər əz pjel de: wuər

әwว:I sə fjeər

bət hə:u ว:I wISt ðət ə:I wər ðعər

bət (h)wen ə:I klım ðə lpfti grə:un(d)

(h)wər livən vi:t ən t $\Lambda$ yz did sə:un(d)

ət fjeər bizə:Id jər blu:mən fjes

ðə pə:rtiıst In a:l ðə pljes

əz ju: did luk wi ə:Iz əz blu:

əz jandər s $\Lambda$ ðən hilz In vju:

vrəm paləduər o: ppli diər

wi ju: $\Lambda \mathrm{p}$ ðعər

hə:u meri ðعn wər ə:I ət fjeər 
Since vu'st I trod thik steep hill-zide

My grievèn soul 'v a-been a-tried

Wi' païn, an' loss o' worldly geär,

An' souls a-gone I wanted near;

But you be here to goo up still,

An' look to Blackmwore vrom the hill

O’ Paladore. Zoo, Polly dear,

We'll goo up there,

An' spend an hour or two at feäir.

The wold brown meäre's a-brought vrom grass,

An' rubb'd an' cwomb'd so bright as glass;

An' now we'll hitch her in, an' start

To feäir upon the new green cart,

An' teäke our little Poll between

Our zides, as proud's a little queen,

To Paladore. Aye, Poll a dear,

Vor now 'tis feäir,

An' she's a-longèn to goo there.

While Paladore, on watch, do strain

Her eyes to Blackmwore's blue-hill'd plaïn,

While Duncliffe is the traveller's mark,

Or cloty Stour's a-rollèn dark;

yellow water-lilied

Or while our bells do call, vor greäce,

The vo'k avore their Seävior's feäce,

Mid Paladore, an' Poll a dear, may Vor ever know

O’ peäce an' plenty down below. 
Sins v $\Lambda$ st ə:I trod ðrk sti:p hilzə:Id mə:I griivən so:l v əbin ətrə:Id wi pæin ən los ə wərrdli giər ən so:lz əgpn ə:I wontıd niər bət ju: bi: hiər to gu: $\Lambda$ p stil ən luk tə blakmuər vrəm ðə hil ə paləduər zu: ppli diər wi:l gu: $\Lambda$ ðعər ən $\operatorname{sp\varepsilon n}(\mathrm{d})$ ən ə:uər ər tu: ət fjeər

ðə (w)uəld brə:un mjeərz əbro:t vrəm gra:s ən r $\wedge$ bd ən kuəmd sə brə:It əz gla:s ən nə:u will hit (h)ər in ən sta:rt tə fjeər əppn ðə nju: gri:n ka:rt ən tjek ə:uər litəl ppl bitwiin ə:uər zə:Idz əz prə:udz ə litəl kwi:n tə paləduər æı ppl ə diər vər nə:u tiz fjeər ən Ji:z əlpyən tə gu: ðعər

(h)wə:Il paləduər pn wpt $\int$ də stræin (h)ər ə:Iz to blakmuərz blu:hild plæin (h)wə:ıl d $\Lambda$ nklıf ız ðə travələrz ma:rk ar klo:ti stə:uərz əro:lən da:rk ar (h)wə:ıl ə:uər belz də ka:l vər grjes ðə vo:k әvuər ðər sjevjərz fjes mid paləduər ən ppl ə diər vər evər no:

ə piəs ən plenti dərun bilo: 
THE BEÄTEN PATH

THE beäten path where vo'k do meet A-comèn on vrom vur an' near;

How many errands had the veet

That wore en out along so clear!

Where eegrass bleädes be green in meäd,

Where bennets up the leäze be brown, An' where the timber bridge do leäd

Athirt the cloty brook to town,

Along the path by mile an' mile,

Athirt the vield, an' brook, an' stile,

There runnèn childern's hearty laugh

Do come an' vlee along-win' swift: fly

The wold man's glossy-knobbèd staff folk far

Do help his veet so hard to lift;

The maid do bear her basket by,

A-hangèn at her breäthèn zide;

An' ceäreless young men, straïght an' spry,

Do whissle hwome at eventide,

Along the path, a-reachèn by

Below tall trees an' oben sky.

There woone do goo to jaÿ a-head; one, joy

Another's jaÿ's behind his back.

There woone his vu'st long mile do tread, first An' woone the last ov all his track.

An' woone mid end a hopevul road, may

Wi' hopeless grief a-teäkèn on,

As he that leätely vrom abroad

Come hwome to seek his love a-gone,

Noo mwore to tread, wi' comely eäse,

The beäten path athirt the leäze.

across the meadow 
ðə biətən pe: $\theta$

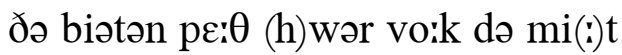

əkımən pn vrəm vərr ən niər

hə:u meni $\varepsilon r ə n(d) z$ had ðə vi:t

ðət wuər ən ə:ut əlpy sə kliər

(h)wər i:gra:s bljedz bi: griin in miəd

(h)wər benits $\Lambda$ дә liəz bi: brə:un

ən (h)wər ðə tımbər br $\Lambda$ dz də liəd əðə:rt ðə klo:ti bruk tə tə:un

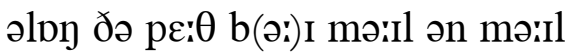
əðə:rt ðə vi:l(d) ən bruk ən stə:Il

ðعər rınən t fildərnz ha:rti le:f də kım ən vli: əlpy win(d) swift ðə (w)uəld manz glpsinpbid ste:f də help (h)IZ vi:t sə ha:rd to lift ðə mæId də beər (h)ər baiskit bə:I əhayən ət (h)ər bri:ðən zə:Id

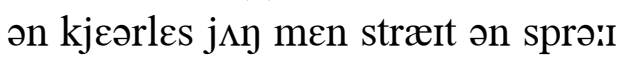
də (h)wisəl huəm ət iivəntəidd

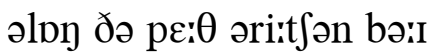
bilo: ta:l trizz ən o:bən skə:I

ðعər (w)u:n də gu: tə dzæI əhed әn^ðərz dzæIz bihə:In(d) (h)Iz bak ðعər (w)u:n (h)Iz vast lpy mə:Il də tred ən (w)u:n ठə le:st əv a:l (h)Iz trak ən (w)u:n mid $\varepsilon$ n(d) ə ho:pvul ro:d wi ho:plis griif ətjekən pn az hi: ðət ljetli vrəm əbro:d k $\Lambda \mathrm{m}$ huəm to si:k (h)Iz $1 \Lambda \mathrm{v}$ əgpn nu: muər to tred wi kımli iəz

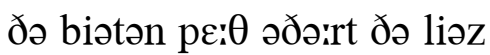


In tweilsome hardships, year by year, toilsome

He drough the worold wander'd wide, through

Still bent, in mind, both vur an near far

To come an' meäke his love his bride.

An' passèn here drough evenèn dew

He heästen'd, happy, to her door,

But vound the wold vo'k only two, old folk

Wi' noo mwore vootsteps on the vloor, To walk ageän below the skies,

Where beäten paths do vall an' rise;

Vor she wer gone vrom e'thly eyes

earthly

To be a-kept in darksome sleep,

Until the good ageän do rise

A jaÿ to souls they left to weep.

The rwose wer doust that bound her brow;

joy

The moth did eat her Zunday ceäpe;

Her frock wer out o' fashion now;

Her shoes wer dried up out o' sheäpeThe shoes that woonce did glitter black once Along the leäzes beäten track. 
In twə:Ilsəm ha:rdfips jiər b(ə:) I jiər

hi: dru: ðə wə:rdəl wondərd wə:Id strl bent In mə:In(d) buəठ və:r ən niər

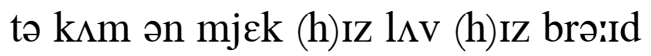
on paisən hiər dru: i:vmən dju:

hi: hjesənd hapi tu (h)ər duər bət və:un(d) ðə (w)uəld vo:k o:nli tu:

wi nu: muər vutsteps pn ठə vluər tə we:k əgjen bilo: ðə skə:IZ (h)wər biətən pe:ðz də va:l ən rə:Iz

var Si: wər gpn vrəm $\varepsilon$ Өli ə:Iz to bi: əkept in da:rksəm sli:p $\Lambda$ tıl ðə gud əgjen də rə:IZ ə dzæi to so:lz ðe: left to wi:p ðə ruəz wər də:ust ðət bə:un(d) (h)ər brə'u

ðə $m p \theta$ did i:t (h)ər zınde: kjep (h)ər frok wər ə'ut ə faJən nə'u

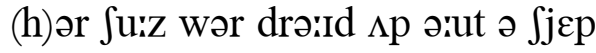

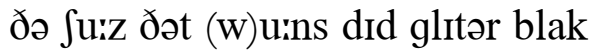
əlpy ðə liəzız biətən trak 


\section{RUTH A-RIDÈN}

Ov all the roads that ever bridge

Did bear athirt a river's feäce, across

Or ho'ses up an' down the ridge

Did wear to doust at ev'ry peäce, dust

I'll teäke the Stalton leäne to tread,

By banks wi' primrwose-beds bespread,

An' steätely elems over head,

Where Ruth do come a-ridèn.

An' I would rise when vields be grey

Wi' mornèn dew, avore 'tis dry, An' beät the doust droughout the day

To bluest hills ov all the sky;

If there, avore the dusk o' night, The evenèn zun, a-sheenèn bright,

Would paÿ my leäbors wi' the zight

O’ Ruth—o' Ruth a-ridèn.

Her healthy feäce is rwosy feäir,

She's comely in her gaï an' lim', An' sweet's the smile her feäce do wear,

Below her cap's well-rounded brim;

An' while her skirt's a-spreädèn wide,

In vwolds upon the ho'se's zide, folds

He'll toss his head, an' snort wi' pride,

To trot wi' Ruth a-ridèn.

An' as her ho'se's rottlèn peäce

Do slacken till his veet do beät

A slower trot, an' till her feäce

Do bloom avore the tollman's geäte; 
ru: $\theta$ ərə:Idən

əv a:l ðə ro:dz ठət $\varepsilon v \partial r$ br $\Lambda d_{3}$ did beər əðə:rt ə rivərz fjes ar hpsiz $\Lambda p$ ən də:un ðə $\mathrm{r} \Lambda \mathrm{d} 3$ did weər to də'ust ət $\varepsilon v r i$ pjes ə:Il tjek ठə sta:lton ljen to tred b(ə:)I bayks wi primruəzbedz bispred ən stjetli عləmz o:vər hed

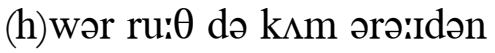

ən ว:I wud rə:Iz (h)wen vi:l(d)z bi: gre:

wi mairnən dju: əvuər tIz drə:I ən biət ðə də:ust druiə;ut ðə de:

to bluisst hilz əv ail ðə skə:I If ðər əvuər ठə $\mathrm{d} \Lambda$ sk ə nə:It

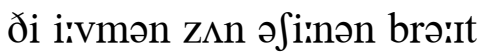
wud pæı mə:ı ljebərz wi ðə zə:It ə ru: $\theta$ ə ru: $\theta$ ərə:Idən

(h)ər helӨi fjes Iz ruəzi fjeər

Sizz k^mli in (h)ər gæit on lim ən swi(:)ts ðə smə:Il (h)ər fjes də weər

bilo: (h)ər kaps welrə:undid brim ən (h)wə:Il (h)ər skə:rts əspredən wə:Id In vuəldz əppn ðə hpsiz zə:Id hi:l tos (h)rz hed on sna:rt wi pro:Id to trpt wi ru: $\theta$ ərə:Idən

ən az (h)ər hpsiz rotlən pjes də slakən tıl (h)Iz vi:t də biət ə slo:ər trpt ən til (h)ər fjes də blu:m əvuər ðə to:lmənz gjet 
Oh! he'd be glad to oben wide

His high-back'd geäte, an' stand azide,

A-givèn up his toll wi' pride,

Vor zight o' Ruth a-ridèn.

An' oh! that Ruth could be my bride,

An' I had ho'ses at my will,

That I mid teäke her by my zide,

might

A-ridèn over dell an' hill;

I'd zet wi' pride her litty tooe

'Ithin a stirrup, sheenèn new, light

An' leäve all other jaÿs to goo

shining

Along wi' Ruth a-ridèn.

joys

If maïdens that be weäk an' peäle

A-mwopèn in the house's sheäde,

Would wish to be so blithe and heäle

bale

As you did zee young Ruth a-meäde;

Then, though the zummer zun mid glow,

Or though the Winter win' mid blow,

They'd leäp upon the saddle's bow,

An' goo, lik' Ruth, a-ridèn.

While evenèn light do sofly gild

The moss upon the elem's bark,

Avore the zingèn bird's a-still'd,

Or woods be dim, or day is dark,

Wi' quiv'rèn grass avore his breast,

In cowslip beds, do lie at rest,

The ho'se that now do goo the best

Wi' rwosy Ruth a-ridèn. 
o: hi:d bi: glad tu o:bən wə:Id

(h)Iz həribakt gjet ən stan(d) əzə:Id əgivən $\Lambda \mathrm{p}(\mathrm{h})$ Iz to:l wi prə:Id vər zəit ə ru: $\theta$ ərə:Idən

ən o: ðət ru: $\theta$ kud bi: mə:I brə:Id ən ə:I had hpsiz ət mə:I wil ðət ə:I mId tjek (h)ər b(ə:)I mə:I zə:Id ərə:Idən o:vər del ən hil ə:Id zet wi prə:Id (h)ər liti tu: ıðın ə stə:rəp Ji:nən nju: ən liəv a:1 $\Lambda$ ðə dzæız to gu: əlpy wi ru: $\theta$ ərə:Idən

If mæIdənz ðət bi: wi:k ən pjel əmuəpən In ðə hə:usız $\int \mathrm{jed}$ wud wi tə bi: sə blə:ıð ən(d) hjel əz jə did zi j j $\rceil$ ru: $\theta$ əmjed

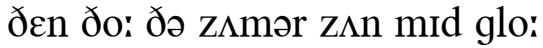
ar ðo: ðə wintər win(d) mId blo: ðe:d liəp əppn ðə sadəlz bo: ən gu: lik ru: $\theta$ ərə:Idən

(h)wə:Il i:vmən lə:it də spfli gild ðə mps əppn ði عləmz bairk әvuər ठə zingən bə:rdz əstıld or wudz bi: dim or de: iz da:rk wi kwIvrən grais əvuər (h)Iz brest In kə:uslıp bedz də lə:I ət rest ðə hps ðət nə:u də gu: ðə best wi ruəzi ru: $\theta$ ərə:Idən 
THE grass mid sheen when wat'ry beäds

O' dew do glitter on the meäds,

An' thorns be bright when quiv'rèn studs

O' rain do hang upon their buds-

As jewels be a-meäde by art

To zet the plaïnest vo'k off smart.

But sheäkèn ivy on its tree,

An' low-bough'd laurel at our knee,

Be bright all däy, without the gleäre,

O' drops that duller leäves mid weär-

As Jeäne is feäir to look upon

In plaïnest gear that she can don. 
bju:ti $\Lambda$ ndekt

ðə gra:s mid fiin (h)wen wə:tri biədz

ə dju: də glitər pn ðə miədz

ən ða:rnz bi: brə:It (h)wen kwivrən st $\Lambda \mathrm{dz}$

ə ræIn də hay əppn ðər bıdz

əz dzuiəlz bi: əmjed b(ə:)I arrt

to zet ðə plæInıst vo:k pf sma:rt

bət $\int j \varepsilon k \partial n$ ə:Ivi pn its tri:

ən lo:bə:ud lprəl ət ə'uər ni:

bi: brə:It a:l de: (w)ıð:ut ðə gljeər

ə draps ðət d $\Lambda$ lər li.vz mid weər

az dzjen iz fjeər to luk əppn

In plæınıst giər ðət $\int i$ i: kən dpn 
MY LOVE IS GOOD

MY love is good, my love is feäir,

She's comely to behold, O,

In ev'rything that she do wear,

Altho' 'tis new or wold, O.

old

My heart do leäp to see her walk,

So straïght do step her veet, $\mathrm{O}$,

My tongue is dum' to hear her talk,

Her vaïce do sound so sweet, $\mathrm{O}$.

The flow'ry groun' wi' floor o' green

Do bear but vew, so good an' true.

When she do zit, then she do seem

The feäirest to my zight, $\mathrm{O}$,

Till she do stan' an' I do deem,

She's feäirest at her height, $\mathrm{O}$.

An' she do seem 'ithin a room

The feäirest on a floor, $\mathrm{O}$,

Till I ageän do zee her bloom

Still feäirer out o' door, O.

Where flow'ry groun' wi' floor o' green

Do bear but vew, so good an' true.

An' when the deäisies be a-press'd

Below her vootsteps waight, $\mathrm{O}$,

Do seem as if she look'd the best

$\mathrm{Ov}$ all in walkèn gaït, $\mathrm{O}$.

Till I do zee her zit upright

Behind the ho'ses neck, O,

A-holdèn wi' the rain so tight

His tossèn head in check, $\mathrm{O}$,

Where flow'ry groun' wi' floor o' green

Do bear but vew, so good an' true. 
mə:I $1 \Lambda \mathrm{v}$ IZ gud

mə:I $1 \Lambda \mathrm{v}$ iz gud mə:I $1 \Lambda \mathrm{v}$ iz fjeər

Si:z kımli to bihuəld o:

In عvriðın ðət $\int \mathrm{i}$ : də weər

a:lðo: tIz nju: ər (w)uəld o:

mə:I hairt də liəp tə zi: (h)ər we:k

sə stræit də step (h)ər viit o:

mə:I t $\Lambda$ y IZ d $\Lambda \mathrm{m}$ tə hiər (h)ər te:k

(h)ər væIs də sə:un(d) sə swiit o:

ðə flə:uri grə:un wi fluər ə gri:n

də beər bət vju: sə gud ən tru:

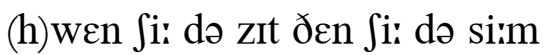

ðə fjeərəst tə mə:I zə:It o:

tıl Si: də stan ən ə:I də di:m

Si:z fjeərəst ət (h)ər hə:It o:

ən $\int i:$ də si(:)m ıðın ə ru:m

ðə fjeərəst pn ə fluər o:

tıl ə:I əgjen də zi: (h)ər blu:m

strl fjeərər ə:ut ə duər o:

(h)wər flə:uri grə:un wi fluər ə gri:n

də beər bət vju: sə gud ən tru:

ən (h)wعn ðə djeziz bi: əprest

bilo: (h)ər vutsteps wæit o:

də si(:)m əz If fii lukt ðə best

əv a:l in we:kən gæit o:

tIl ə:I də zi: (h)ər zit $\Lambda$ prə:It

bihə:In(d) ठə hpsız nek o:

əho:ldən wi ðə ræIn sə tə:It

(h)Iz tosən hed in t $\int \varepsilon k$ o:

(h)wər flə:uri grə:un wi fluər ə grimn

də beər bət vju: sə gud ən tru: 
I wish I had my own free land

To keep a ho'se to ride, $\mathrm{O}$,

I wish I had a ho'se in hand

To ride en at her zide, $\mathrm{O}$.

Vor if I wer as high in rank

As any duke or lord, $\mathrm{O}$,

Or had the goold the richest bank

Can shovel from his horde, $\mathrm{O}$,

I'd love her still, if even then

She wer a leäser in a glen.

gleaner 
ว:I WI

to $\mathrm{ki}(:) \mathrm{p}$ ə hps to rə:Id o:

ว:I WI $\int$ ว:I had ə hps in han(d)

tə rə:Id ən at (h)ər zə:Id o:

var If ə:I wər əz hə:I In rayk

əz عni dju:k ər la:rd o:

ar had ðə gu:ld ðə rit $\int$ Ist bayk

kən $\int \Lambda$ vəl vrəm (h)Iz ha:rd o:

ə:Id $1 \Lambda \mathrm{v}$ (h)ər stıl If iivən ठعn

fi: wər ə liəzər In ə glen 
HEEDLESS O’ MY LOVE

OH! I vu'st know'd o' my true love,

As the bright moon up above,

Though her brightness wer my pleasure,

She wer heedless o' my love.

Tho' 'twer all gaÿ to my eyes,

Where her feäir feäce did arise,

She noo mwore thought upon my thoughts,

Than the high moon in the skies.

Oh! I vu'st heärd her a-zingèn,

As a sweet bird on a tree,

Though her zingèn wer my pleasure,

'Twer noo zong she zung to me.

Though her sweet vaïce that wer nigh,

Meäde my wild heart to beat high,

She noo mwore thought upon my thoughts,

Than the birds would passers by.

Oh! I vu'st know'd her a-weepèn,

As a raïn-dimm'd mornèn sky,

Though her teär-draps dimm'd her blushes,

They wer noo draps I could dry.

Ev'ry bright tear that did roll,

Wer a keen païn to my soul,

But noo heärt's pang she did then veel,

Wer vor my words to console.

But the wold times be a-vanish'd,

An' my true love is my bride.

An' her kind heart have a-meäde her

As an angel at my zide; 
hi:dlis ə mə:I $1 \Lambda \mathrm{v}$

o: əII vıst no:d ə mə:I tru: $1 \Lambda \mathrm{v}$

az ðə brə:It mu:n $\Lambda \mathrm{p}$ əb $\Lambda \mathrm{v}$

ðo: (h)ər brə:Itnis wər mə:I plezər

Si: wər hi:dlis ə mə:I $1 \Lambda \mathrm{v}$

ðo: twər a:l gæi tə mə:I ə:IZ

(h)wər (h)ər fjeər fjes did ərə:Iz

fi: nu: muər ðo:t əppn mə:I ðo:ts

ðən ðə hə:I mu:n In ðə skə:IZ

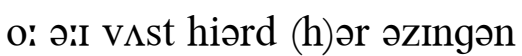

az ə swi(:)t bə:rd pn ə tri:

ðo: (h)ər zingən wər mə:ı plezər

twor nu: zpy Ji: zAy to mi:

ðo: (h)ər swi(:)t væıs ðat wər nə:I mjed mə:I wə:Il(d) hairt to biət hə:I

Si: nu: muər ðo:t әppn mə:I ðo:ts

ðən ðə bə:rdz wud pa:sərz bə:I

o: ə:I vıst no:d (h)ər əwi:pən

az ə ræindimd ma:rnən skə:I

ðo: (h)ər tiərdraps dimd (h)ər bl $\Lambda \int \mathrm{Iz}$

ðе: wər nu: draps ə:I kud drə:I

عvri brə:It tiər ðət did ro:l

wər ə ki:n pæin tə mə:I so:l

bət nu: ha:rts pay Ji: did ðen vi:l

wər vər mə:I wə:rdz tə kənso:l

bət ðə (w)uəld tə:Imz bi: əvanift

ən mə:I tru: $1 \Lambda \mathrm{V}$ IZ mə:I brə:Id

ən (h)ər kə:In(d) ha:rt hav əmjed hər

az on andzəl ət mə:I zə:Id 
I've her best smiles that mid plaÿ,

I've her me'th when she is gaÿ,

mirth

When her tear-draps be a-rollèn,

I can now wipe em awaÿ. 
ə:IV (h)ər best smə:Ilz ðət mId plæI

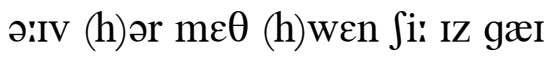

(h)wen (h)ər tiərdraps bi: əro:lən

ว:I kən nə:u wə:ıр əm əwə:I 
THE DO’SET MILITIA

HURRAH! my lads, vor Do'set men!

A-muster'd here in red ageän;

All welcome to your ranks, a-spread

Up zide to zide, to stand, or wheel,

An' welcome to your files, to head

The steady march wi' tooe to heel;

Welcome to marches slow or quick!

Welcome to gath'rèns thin or thick;

God speed the Colonel on the hill,

An' Mrs Bingham, off o' drill.

When you've a-handled well your lock,

An' flung about your rifle stock

Vrom han' to shoulder, up an' down;

When you've a-lwoaded an' a-vired,

Till you do come back into town,

Wi' all your loppèn limbs a-tired,

drooping

An' you be dry an' burnèn hot,

Why here's your tea an' coffee pot

At Mister Greenèn's penny till,

Wi' Mrs Bingham off o' drill.

Last year John Hinley's mother cried,

"Why my bwoy John is quite my pride!

Vor he've a-been so good to-year,

An' han't a-mell'd wi' any squabbles,

got involved in

An' han't a-drown'd his wits in beer,

An' han't a-been in any hobbles.

awkward situations

I never thought he'd turn out bad,

He always wer so good a lad;

But now I'm sure he's better still,

Drough Mrs Bingham, off o' drill.",

through 
ðə dpsət milisə

həra: mə:I ladz vər dpsət men

əmıstərd hiər in red əgjen

a:l welkəm to jər rayks əspred

$\Lambda p$ zə:Id to zə:Id to $\operatorname{stan}(\mathrm{d})$ ər (h)will

ən welkəm tə jər fə:Ilz tə hed

ðə stedi ma:rt wi tu: to hi:l

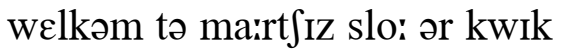

welkəm to gaðrənz ðın ər $\theta$ rk

gpd spi:d ðə kə:rnəl pn ðə hıl

ən misiz bijəm pf ə dril

(h)wen jəv əhandəld wel jər lpk ən flıy əbə:ut jər rə:Ifəl stpk vrəm han tə So:ldər $\Lambda \mathrm{p}$ ən də:un

(h)wen jəv əluədid ən əvə:ıərd

tıl jə də kım bak intə tə:un

wi a:l jər lopən limz ətə:Iərd

ən jə bi: drə:I ən bərrnən hpt

(h)wə:I hiərz jər te: ən kpfi ppt

at mistər grimənz peni til

wi misız bijəm pf ə dril

le:st jiər dzan hə:Inliz m^ðər krə:Id

(h)wə:I mə:I bwə:I dzan Iz kwə:It mə:I prə:Id

vər hi:v əbın sə gud təjiər

ən hant əmeld wi عni skwpbəlz

ən hant ədrə:und (h) Iz wits in bior

ən hant əbIn In eni hpbolz

ə:I nevər ðo:t hi:d tə:rn ə:ut bad

hi: a:lwe:z wər sə gud ə lad

bət nə:u ə:Im $\int \mathrm{u}($ (:)ər hi:z betər strl

dru: misiz binəm pf a dril 
Jeäne Hart, that's Joey Duntley's chaïce,

Do praise en up wi' her sweet vaïce,

Vor he's so strait's a hollyhock

(Vew hollyhocks be up so tall),

An' he do come so true's the clock

To Mrs Bingham's coffee-stall;

An' Jeäne do write, an' bag o' Joe

To teäke the young recruits in tow,

An' try, vor all their good, to bring em,

A-come from drill, to Mrs Bingham.

God speed the Colonel, toppèn high,

An' officers wi' sworded thigh,

An' all the sargeants that do bawl

All day enough to split their droats,

An' all the corporals, and all

The band a-plaÿèn up their notes,

An' all the men vrom vur an' near,

We'll gi'e em all a hearty cheer,

An' then another cheerèn still

give

Vor Mrs Bingham, off o' drill. 
dzjen ha:rt ðəts dzo:i d $\Lambda$ ntliz t $\int æ i s$ də præIz ən $\Lambda$ p wi (h)or swi(:)t væIS vər hi:z sə stræits ə hplihpk vju: hplihpks bi: $\Lambda$ p sə ta:l ən hi: də k^m sə tru:z ðə klpk to misiz binəmz kpfista:l ən dzjen də rə:It ən bag ə dzo: tə tjek ðə j $\Lambda$ y rikruits In to: ən trə:I vər a:l ðər gud to brin əm əkım vrəm dril tə misiz bijəm

gpd spi:d ðə kə:rnəl tppən hə:I ən pfisərz wi suərdid $\theta$ ə:I ən a:l ðə sa:rdzənts ðət də ba:l a:l de: insf to split ðər dro:ts ən a:l ठə ka:rpərəlz ən(d) a:l ðə ban(d) əplæıən $\Lambda$ p ðər no:ts ən a:l ठə men vrəm vərr ən niər will gi: əm a:l ə harti tfiər ən ðદn ən^ðər tfiərən stıl vər misız bijəm pf ə dril 


\section{A DO'SET SALE}

WITH A MISTAKE

(Thomas and Mr Auctioneer.)

T. Well here, then, Mister auctioneer,

Be theäse the virs, I bought, out here?

these

$A$. The firs, the fir-poles, you bought? Who?

'Twas furze, not firs, I sold to you.

T. I bid vor virs, and not vor vuzzen,

Vor vir-poles, as I thought, two dozen.

$A$. Two dozen faggots, and I took

Your bidding for them. Here's the book.

T. I wont have what I diddèn buy.

I don't want vurzen, now. Not I.

Why firs an furze do sound the seäme.

Why don't ye gi'e a thing his neäme?

Aye, firs and furze! Why, who can tell

Which 'tis that you do meän to zell?

No, no, be kind enough to call

Em virs, and vurzen, then, that's all. 
ə dosət sjel

wi(ð) ə mistjek

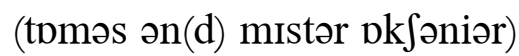

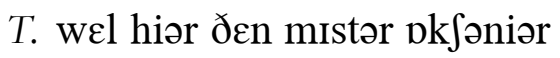

bi: ðiəz ðə və:rz ə:I bə:t ə:ut hiər

A. ðə fə:rz ðə fə:rpo:lz jə bə:t hu: twəz fə:rz not fərrz ə:I so:ld to ju:

T. ə:I bId vər və:rz ən(d) npt vər vızən

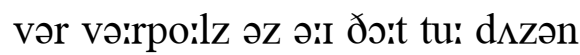

$A$. tu: $\mathrm{d} \Lambda$ zən fagəts $ə$ (d) ə:I tok jər bidın vər ðعm hiərz ðə buk

T. ə:I wu(:)nt hav (h)wpt ə:I didən bə:I ə:I do:nt wpnt vizən nə:u npt əiI (h)wə:I fə:rz ən fə:rz də sə:un(d) ðə sjem (h)wə:I do:nt i: gi: ə ðıy (h)ız njem æI fə:rz ən(d) fə:rz (h)wə:I hu: kən tel (h)wit tiz dət jə də miən tə zel no: no: bi: kə:In(d) in $\wedge f$ to ka:l

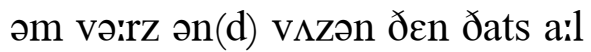


AT the feäst, I do mind very well, all the vo'ks folk

Wer a-took in a happerèn storm, pelting like bail

But we chaps took the maïdens, an' kept em wi' clokes

Under shelter, all dry an' all warm;

An' to my lot vell Jeäne, that's my bride,

That did titter, a-hung at my zide;

Zaid her aunt, "Why the vo'k 'ull talk finely o' you,"

An', cried she, "I don't ceäre if they do."

When the time o' the feäst wer ageän a-come round,

An' the vo'k wer a-gather'd woonce mwore,

once

Why she guess'd if she went there, she'd soon be a-vound

An' a-took seäfely hwome to her door.

Zaid her mother, "Tis sure to be wet."

Zaid her cousin, "'T'ull rain by zunzet."

Zaid her aunt, "Why the clouds there do look black an' blue,"

An' zaid she, "I don't ceäre if they do."

An' at last, when she own'd I mid meäke her my bride,

might

Vor to help me, an' sheäre all my lot,

An' wi' faïthvulness keep all her life at my zide,

Though my waÿ mid be happy or not,

Zaid her naïghbours, "Why wedlock's a clog,

An' a wife's a-tied up lik' a dog."

Zaid her aunt, "You'll vind trials enough vor to rue,"

An', zaid she, "I don't ceäre if I do."

Now she's married, an' still in the midst ov her tweils

toils

She's as happy's the daylight is long,

She do goo out abroad wi' her feäce vull o' smiles,

An' do work in the house wi' a zong. 
do:nt kjeər

at ðə fiəst ə:I də mə:In(d) veri wعl a:l ðə vo:ks wər ətuk in ə hapərən sta:rm bət wi: t taps tuk ðə mæidənz ən kept əm wi klo:ks $\Lambda$ ndər $\int \varepsilon l t ə r$ a:l drə:I ən a:l wa:rm ən tə mə:I lpt vel dzjen ðəts mə:I brə:Id ðat did titər əh^y ət mə:I zə:Id zed (h)ər ع:nt (h)wə:I ðə vo:k ul te:k fə:Inli ə ju: ən krə:Id fi: ə:I do:nt kjeər If ðe: du:

(h)wen ðə tə:Im ə ðə fiəst wər əgjen əkım rə:un(d) ən ðə vo:k wər əgaðərd (w)u:ns muər

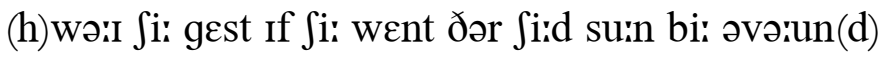
ən ətuk sjefli huəm tu (h)ər duər zed (h)ər mıðər tız $\int \mathrm{u}(\mathrm{i}) \partial \mathrm{r}$ tə bi: wet zed (h)ər kızən tol ræIn b(ə:)I zınzet zed (h)ər ع:nt (h)wə:ı ðə klə:udz ðər də luk blak ən blu: ən zed fi: ə:I do:nt kjeər If ðe: du:

ən at le:st (h)wen Si: o:nd ə:I mid mjek (h)ər mə:I brə:Id var to help mi: ən Sjeər a:l mə:I lpt ən wi fæi $\theta$ vulnıs ki(:)p a:l (h)ər lə:ıf ət mə:I zə:Id

ðo: mə:I wæI mId bi: hapi ar not zed (h)ər næibərz (h)wə:I wedlpks ə klpg ən $ə$ wə:Ifs ətə:Id $\Lambda \mathrm{p}$ lik $\partial \mathrm{dpg}$ zed (h)ər ع:nt ju:l və:In(d) trə:Iəlz in $\Lambda$ f var tə ru: ən zed fi: ə:I do:nt kjeər If ə:I du:

nə:u Si:z marid ən stıl in ðə midst əv (h)ər twə:Ilz Ji:z əz hapi z ðə de:lə:It Iz lon fi: də gu: ərut əbro:d wi (h)ər fjes vul ə sməillz ən də wərrk In ðə hə:us wi ə zpy 
An', zays woone, "She don't grieve, you can tell."

Zays another, "Why, don't she look well!"

Zays her aunt, "Why the young vo'k do envy you two,"

An', zays she, "I don't ceäre if they do."

Now vor me I can zing in my business abrode,

Though the storm do beät down on my poll,

out and about

There's a wife-brighten'd vier at the end o' my road, head

An' her love vor the jaÿ o' my soul.

fire

Out o' door I wi' rogues mid be tried:

joy

Out o' door be brow-beäten wi' pride;

may

Men mid scowl out o' door, if my wife is but true-

Let em scowl, "I don't ceäre if they do." 
ən zez (w)u:n Si: do:nt gri:v jə kən tel zez ən^ðər (h)wə:I do:nt Si: luk wel

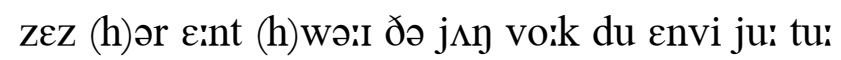

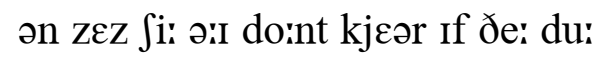

nə:u var mi: ə:I kən zin In mə:I biznis əbro:d ðо: ðə sta:rm də biət də:un pn mə:I po:l ðərz ə wə:Ifbrə:Itənd və:ıər at ði $\varepsilon n(d)$ ə mə:I ro:d ən (h)ər $1 \Lambda \mathrm{v}$ var ðə dzæI ə mə:I so:l ə:ut ə duər ə:I wi ro:gz mid bi: trə:Id ə:ut ə duər bi: brə:u biətən wi prə:Id men mid skə:ul ə:ut ə duər If mə:I wə:If Iz bət tru: let əm skə:ul ə:I do:nt kjeər If ðe: du: 


\section{CHANGES [1]}

BY time's a-brought the mornèn light,

By time the light do weäne;

wane

By time's a-brought the young man's might,

By time his might do weäne;

The Winter snow do whitèn grass,

The zummer flow'rs do brightèn grass,

Vor zome things we do lose wi' païn,

We've mwore that mid be jaÿ to gaïn,

An' my dear life do seem the seäme

While at my zide

There still do bide

Your welcome feäce an' hwomely neäme.

Wi' ev'ry day that woonce come on

I had to choose a jaÿ,

Wi' many that be since a-gone

I had to lose a jaÿ.

Drough longsome years a-wanderèn,

through

Drough lwonesome rest a-ponderèn,

Woone peaceful daytime wer a-bro't

one, brought

To heal the heart another smote;

But my dear life do seem the seäme

While I can hear,

A-soundèn near,

Your answ'rèn vaïce an' long-call'd neäme.

An' oh! that hope, when life do dawn,

Should rise to light our waÿ,

An' then, wi' weänèn het withdrawn,

Should soon benight our waÿ. 
t $\int a n d z I z$

b(ə:)I tə:Imz əbro:t ðə ma:rnən lə:It

b(ə:)I tə:Im ðə lə:It də wjen

b(ə:)I tə:Imz əbro:t ðə j $\wedge$ y manz mə:It

b(ə:)I tə:Im (h)Iz mə:It də wjen

ðə wintər sno: də (h)wə:itən gra:s

ðə z^mər flə:uərz də brə:itən gra:s

vər z^m ðıyz wi: də lu:z wi pæin

wisv muər ठət mid bi: dzæI to gæın

ən mə:I diər lə:ıf də si(:)m ðə sjєm

(h)wə:Il at mə:I zə:Id

ðər stıl də bə:Id

ju(:)ər welkəm fjes ən huəmli njem

wi عvri de: ðət (w)urns k^m pn

ə:I had to tfu:z ə dzæI

wi meni ðət bi: sins əginn

ə:I had to lu:z ə dzæI

dru: lpysəm jiərz əwpndərən

dru: luənsəm rest əppndərən

(w)u:n pissful de:tə:Im wər əbro:t

tə hi:l ðə ha:rt ən^ðər smo:t

bət mə:I diər lə:If də si(:)m ðə sjem

(h)wə:Il ə:I kən hiər əsə่un(d)ən niər

j(u:)ər ع:nsrən væIs ən lpyka:ld njem

ən o: ðət ho:p (h)wen lə:If də de:n

jud rə:Iz tə lə:It ə:uər wæI

ən ðعn wi wjenən het wiðdre:n

ऽud su:n binə:It ə:uər wæI 
Whatever mid beval me still,

Wherever chance mid call me still,

Though leäte my evenèn tweil mid cease,

An' though my night mid lose its peace,

My life will seem to me the seäme

While you do sheäre

My daily ceäre,

An' answer to your long-call'd neäme. 
(h)wptevər mid biva:l mi: stıl

(h)wərevər t $\int \varepsilon: n s$ mid ka:l mi: stıl ðо: ljet mə:I i:vmən twə:Il mid si:s ən ðo: mə:I nə:It mid lu:z its piss mə:ı lə:If wıl si(:)m tə mi: ðə sjem (h)wə:Il ju: də fjeər mə:I de:li kjeər ən ع:nsər to jər lojkaild njem 


\section{KINDNESS}

GOOD Meäster Collins heärd woone day

A man a-talkèn, that did zay

It woulden answer to be kind,

He thought, to vo'k o' grov'lèn mind,

Vor they would only teäke it wrong,

That you be weak an' they be strong.

"No," cried the goodman, "never mind,

Let vo'k be thankless,- - you be kind;

Don't do your good for e'thly ends

earthly

At man's own call vor man's amends.

Though souls befriended should remain

As thankless as the sea vor rain,

On them the good's a-lost 'tis true,

But never can be lost to you.

Look on the cool-feäced moon at night

Wi' light-vull ring, at utmost height,

A-castèn down, in gleamèn strokes,

His beams upon the dim-bough'd woaks,

oaks

To show the cliff a-risèn steep,

To show the stream a-vallèn deep,

To show where windèn roads do leäd,

An' prickly thorns do ward the meäd.

While sheädes o' boughs do flutter dark

shadows

Upon the woak-trees' moon-bright bark,

There in the lewth, below the hill,

shelter

The nightèngeäle, wi' ringèn bill,

Do zing among the soft-airr'd groves,

While up below the house's oves

eaves

The maid, a-lookèn vrom her room

Drough window, in her youthvul bloom,

through

Do listen, wi' white ears among

Her glossy heäirlocks, to the zong. 
kə:Indnis

gud mja:stər kplınz hiərd (w)u:n de:

ə man ətદ:kən ðət did ze:

It (w)Udən ع:nsər to bi: kə:In(d)

hi: ठs:t tə vo:k ə grovlən mə:In(d)

vər ðe: wud o:nli tjek it roy

ðət ju: bi: wi:k ən ðe: bi: strpy

no: krə:Id ðə gudman nevər mə:In(d)

let vo:k bi: $\theta$ anklis ju: bi: kə:In(d)

do:nt du: jor gud vor $\varepsilon \theta 1 i$ $\varepsilon n(d) z$

ət manz o:n ka:l vər manz əmen(d)z

ðo: so:lz bifrendid fud rimæin

әz Өạklıs əz ðə si: vər ræı

pn ðعm ðə gudz əlpst tız tru:

bət nevər kan bi: lost tə ju:

luk pn ðə ku:lfjest mu:n ət nə:It

wi lə:itvul rig ət $\Lambda$ tmo:st hə:It

əka:stən dərun In gli:mən stro:ks

(h)Iz bi:mz əppn ðə dımbərud (w)uəks

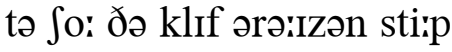

to So: ðə stri:m əva:lən di:p

to fo: (h)wər wə:In(d)ən ro:dz də liəd

ən prikli ða:rnz də wa:rd ðə miəd

(h)wə:Il Jjedz ə bə:uz də flıtər da:rk əppn ठə (w)uəktri:z mu:nbrə:It ba:rk

ðər in ðə lu: $\theta$ bilo: ðə hil

ðə nə:Itəngjel wi rinən bil

də zIy əmpy ðə spftæird gro:vz

(h)wə:Il $\Lambda$ p bilo: ðə hə:usız o:vZ

ðə mæId əlukən vrəm (h)ər ru:m

dru: windər in (h)ər ju:Өvul blu:m

də lisən wi (h)wə:It iərz əmpy

(h)ər glpsi hjeərlpks tə ðə zpy 
If, then, the while the moon do light The lwonesome zinger o' the night, His cwold-beam'd light do seem to show The prowlèn owls the mouse below, What then? Because an evil will,

Ov his sweet good, mid meäke zome ill, may Shall all his feäce be kept behind The dark-brow'd hills to leäve us blind?" 
If ðعn ðə (h)wə:Il ðə mu:n də lə:It ðə luənsəm zIjər ə ðə nə:it (h)Iz kuəldbi:md lə:It də si(:)m to Jo: ðə prə:ulən ə:ulz ðə mə:us bilo: (h)wpt ðعn bikje:z ən iivəl wil əv (h)IZ swi(:)t gud mid mjek zım Il Jal a:l (h)Iz fjes bi: kept bihə:In(d) ðə darkbrə:ud hilz tə liəv əs blə:In(d) 
WHEN weakness now do strive wi' might

In struggles ov an e'thly trial, earthly

Might mid overcome the right, may

An' truth be turn'd by might's denial;

Withstanders we ha' mwost to feär,

If selfishness do wring us here,

Be souls a-holdèn in their hand,

The might an' riches o' the land.

But when the wicked, now so strong,

Shall stan' vor judgment, peäle as ashes,

By the souls that rued their wrong,

Wi' tears a-hangèn on their lashes-

Then withstanders they shall deäre

The leäst ov all to meet wi' there,

Mid be the helpless souls that now

Below their wrongvul might mid bow.

Sweet childern o' the dead, bereft

Ov all their goods by guile an' forgèn;

Souls o' driven sleäves that left

Their weäry limbs a-mark'd by scourgèn;

They that God ha' call'd to die

Vor truth ageän the worold's lie,

An' they that groan'd an' cried in vain,

A-bound by foes' unrighteous chaïn.

The maid that selfish craft led on

To sin, an' left wi' hope a-blighted;

Starvèn workmen, thin an' wan,

Wi' hopeless leäbour ill requited; 
wıðstandərz

(h)wen wi:knis nə:u də strə:IV wi mə:It

In str $\Lambda$ gəlz əv ən $\varepsilon \theta$ li trə:Iəl

mə:It mid oivərkım ðə rə:It

ən tru: $\theta$ bi: tə:rnd $b(ə:)$ I mə:its dinə:iəl

wiðstandərz wi: ha muəst tə fiər

If selfifnis də rin əs hiər

bi: so:lz əho:ldən In ðər han(d)

ðə mə:It ən rit $\int \mathrm{Iz} ə$ əə $\operatorname{lan}(\mathrm{d})$

bət (h)wعn ðə wikıd nə:u sə strpy

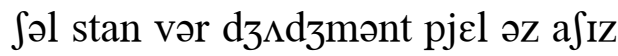

b(ə:)I ðə so:lz ðət ru:d ðər ron

wi tiərz əhayən pn ðər la laz

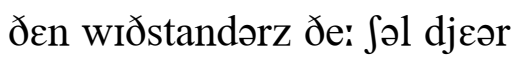

ðə liəst əv ail tə mi(:)t wi ðعər

mId bi: ðə helplis so:lz ðət nə:u

bilo: ðər royvul mə:It mid bə:u

swi(:)t t f Ildərn ə ðə ded bireft

əv a:l ðər gudz b(ə:)I gə:Il ən fuərdzən

so:lz ə drivən sljevz ðət left

ðər wiəri limz əma:rkt b(ə:)I skuərdzən

ðe: ðət gpd hə ka:ld tə də:I

vər tru: $\theta$ əgjen ðə wə:rdəlz lə:I

ən ðе: ठət gro:nd ən krə:Id In væin

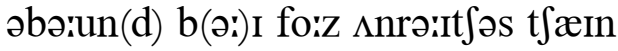

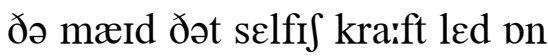

to sin ən left wi ho:p əblə:itid

sta:rvən wə:rkmen ðın ən wpn

wi ho:plis ljebər il rikwə:Itıd 
Souls a-wrong'd, an' call'd to vill

Wi' dread, the men that us'd em ill.

When might shall yield to right as pliant

As a dwarf avore a giant.

When there, at last, the good shall glow

In starbright bodies lik' their Seäviour,

Vor all their flesh noo mwore mid show,

The marks o' man's unkind beheäviour:

Wi' speechless tongue, an' burnèn cheak,

The strong shall bow avore the weäk,

An' vind that helplessness, wi' right,

Is strong beyond all e'thly might.

eartbly 
so:lz ərond ən ka:ld to vil

wi dred ðə men ðət ju:zd əm Il

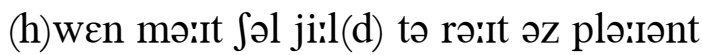

əz ə dwairf əvuər ə dzə:Iənt

(h)wen ðعər at le:st ðə gud Səl glo:

In sta:rbrə:It bodiz lik ðər $\int j \varepsilon v j ə r$

vər a:l ðər fle $\int$ nu: muər mId So:

ðə ma:rks ə manz $\Lambda$ kəə:In(d) bihjevjər

wi spirtflis t $\Lambda$ y ən bərnən t tjiək

ðə strpy Jəl bə:u əvuər ðə wiək

ən və:In(d) ðət helplisnis wi rə:It

IZ strpy bijand a:l $\varepsilon \theta$ li mə:it 
DAN DwITHEN wer the chap to show

His naighbours mwore than they did know,

Vor he could zee, wi' half a thought,

What zome could hardly be a-taught;

An' he had never any doubt

Whatever 'twer, but he did know't,

An' had a-reach'd the bottom o't,

Or soon could meäke it out.

Wi' narrow feäce, an' nose so thin

That light a'most shone drough the skin, through

As he did talk, wi' his red peäir

O' lips, an' his vull eyes did steäre,

What nippy looks friend Daniel wore,

clever

An' how he smiled as he did bring

Such reasons vor to clear a thing,

As dather'd vo'k the mwore!

confused folk.

When woonce there come along the road

once

At night, zome show-vo'k, wi' a lwoad

Ov half the wild outlandish things

That crawl'd, or went wi' veet, or wings;

Their elephant, to stratch his knees,

Walk'd up the road-zide turf, an' left

His tracks a-zunk wi' all his heft

weight

As big's a vinny cheese.

blue vinny (made from skimmed milk.)

An' zoo next mornèn zome vo'k vound

The girt round tracks upon the ground,

great

An' view'd em all wi' stedvast eyes,

An' wi' their vingers spann'd their size, 
danəl dwıðən ðə wə:Iz t $\int a p$

dan dwıðən wər ðə t $\int a p$ tə $\int o:$

(h)Iz næibərz muər ðən ðе: did no:

vər hi: kud zi: wi he:f ə ठっ:t

(h)wpt zım kud hardli bi: əto:t

ən hi: had nevər eni də:ut

(h)wptevər twor bət hi: did no:t

ən had əri:tst ðə botəm o:t

ar su:n kud mjek it ərut

wi narə(r) fjes ən no:z sə ðın

ðət lə:It a:məst $\int p n$ dru: ðə skin

əz hi: did te:k wi (h)Iz red pjeər

ə lips ən (h)Iz vol ə:Iz did stjeər

(h)wpt nipi luks fren(d) danəl wuər

ən hə'u hi: smərild əz hi: did brin

sit ri:zənz vər to kliər ə ठıy

əz daðərd vo:k ðə muər

(h)wen (w)u:ns ðər kım əlpy ðə ro:d

ət nə:It z^m So:vo:k wi ə luəd

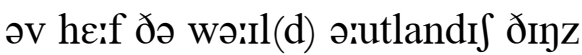

ðət kra:ld ər went wi viit ər winz

ðər عlifənt to strat $\int(h)$ Iz ni:z

we:kt $\Lambda p$ ðə ro:dzə:Id tə:rf ən left

(h)Iz traks əz^yk wi a:l (h)Iz heft

oz bigz ə vini tfi:z

ən zu: ncks(t) ma:rnən z^m vo:k və'un(d)

ðə gə:rt rə:un(d) traks əppn ðə grə:un(d)

ən vju:d əm a:l wi stedvaist ə:Iz

ən wi ðər vingərz spand ðər sə:Iz 
An' took their depth below the brink:

An' whether they mid be the tracks

O' things wi' witches on their backs,

Or what, they coulden think.

At last friend Dan come up, an' brought

His wit to help their dizzy thought,

An' lookèn on an' off the ea'th,

earth

He cried, a-drawèn a vull breath,

"Why, I do know; what, can't ye zee 't?

I'll bet a shillèn 'twer a deer

Broke out o' park, an' sprung on here,

Wi' quoits upon his veet." 
ən tuk ðər dep $\theta$ bilo: ðə brınk

ən (h)weðər ðe: mId bi: ðə traks

ə ðInz wi wit $\int \mathrm{Iz}$ pn ðər baks

ar (h)wpt ðe: kudən ðink

ət le:st fren(d) dan kım $\Lambda p$ ən broit

(h)Iz wit to help ðər dizi ðっ:t

ən lukən pn ən pf ði $\varepsilon \theta$

hi: krə:Id ədre:ən ə vul bre $\theta$

(h)wə:I ə:I də no: (h)wpt ke:nt i: zi:t

ə:Il bet ə filən twər ə diər

bro:k ərut ə pairk ən spr^y pn hiər

wi kwæits əppn (h)IZ vi:t 
UPZIDES wi' Polly! no, he'd vind even with

That Poll would soon leäve him behind.

To turn things off! oh! she's too quick

To be a-caught by ev'ry trick.

Woone day our Jimmy stole down steäirs

On merry Polly unaweäres,

The while her nimble tongue did run

A-tellèn, all alive wi' fun,

To sister Anne, how Simon Heäre

Did hanker after her at feäir.

"He left," cried Polly, “cousin Jeäne,

An' kept wi' us all down the leäne,

An' which waÿ ever we did leäd

He vollow'd over hill an' meäd;

An' wi' his head o' shaggy heäir,

An' sleek brown cwoat that he do weäre,

An' collar that did reach so high

'S his two red ears, or perty nigh,

He swung his täil, wi' steps o' pride,

Back right an' left, vrom zide to zide,

A-walkèn on, wi' heavy strides

A half behind, an' half upzides."

alongside

"Who's that?" cried Jimmy, all agog;

An' thought he had her now han'-pat,

"That's Simon Heäre," but no, "Who's that?"

in his grasp

Cried she at woonce, "Why Uncle's dog, once

Wi' what have you a-been misled

I wonder. Tell me what I zaid."

Woone evenèn as she zot bezide

sat

The wall the ranglèn vine do hide, climbing

A-prattlèn on, as she did zend

Her needle, at her vinger's end, 
tə:rnən ðıрz pf

«pzə:Idz wi ppli no: hi:d və:In(d)

ðət ppl wud su:n liəv him bihə:In(d)

to tə:rn ðınz pf o: Ji:z tu: kwik

to bi: əko:t b(ə:)I Evri trik

(w)u:n de: ə:uər d3ımi sto:l də:un stjeərz

pn meri ppli «nəweərz

ðə (h)wəril (h)ər nImbəl t $\wedge$ y did r $\wedge n$

ətદlən a:l ələ:IV wi fın

tə sistər an hə:u sə:Imən hjeər

did haykər ع:tər (h)ər ət fjeər

hi: left krə:Id ppli kızən dzjen

ən kept wi $\Lambda$ s a:l də:un ðə ljen

ən (h)wit $\int$ wæi Evər wi: did liəd

hi: vplid o:vər hil on miəd

ən wi (h)rz hed ə Sagi hjeər

ən sli:k brə:un kuət ðət hi: də weər

ən kplər ðət did ritt sə hə:I

$\mathrm{z}$ (h)Iz tu: red iərz ar pərrti nə:I

hi: swıy (h)Iz tæil wi steps ə prəiId

bak rə:It on left vrəm zə:Id tə zə:Id

əwع:kən pn wi hevi strə:Idz

ə he:f bihə:In(d) ən he:f $\Lambda$ pzə:Idz

hu:z ðat krə:Id dzImi a:l əgpg

ən ठว:t hi: had (h)ər nə:u hanpat

ðats sə:Imən hjeər bət no: huiz ðat

krə:Id fi: ət (w)u:ns (h)wə:I $\Lambda$ ykəlz dpg

wi (h)wpt həv ju: əbin misled

ə:I wandər tel mi: (h)wpt ə:I zed

(w)uin i:vmən əz fi: zat bizəiıd

ðə wa:l ðə rayglən və:In də hə:Id

əpratlon pn $ә z$ Ji: did zen(d)

(h)ər nIdəl ət (h)ər vingərz $\varepsilon n(d)$ 
On drough the work she had in hand,

Zome bran-new thing that she'd a-plann'd,

Jim overheärd her talk ageän

O’ Robin Hine, ov Ivy Leäne,

"Oh! no, what he!" she cried in scorn,

"I wouldèn gie a penny vor'n;

for bim

The best ov him's outzide in view;

His cwoat is gaÿ enough, 'tis true,

But then the wold vo'k didden bring

old folk didn't

En up to know a single thing,

bim

An' as vor zingèn,-—what do seem

His zingèn's nothèn but a scream."

"So ho!" cried Jim, "Who's that, then, Meäry,

That you be now a-talkèn o'?"

He thought to catch her then, but, no,

Cried Polly, “Oh! why Jeäne's caneäry,

Wi' what have you a-been misled,

I wonder. Tell me what I zaid." 
pn dru: ðə wə:rk Ji: had in han(d)

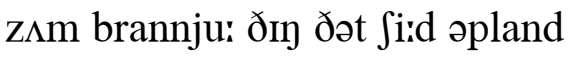
dzIm эivərhiərd (h)ər te:k əgjen ə robin hə:In əv ə:Ivi ljen o: no: (h)wpt hi: fi: krə:Id in ska:rn ə:I (w)udən gi: ə peni va:rn ðə best əv hImz ə'utzə:Id In vju: (h)Iz kuət Iz gæi in $\Lambda$ f tzz tru: bət ðعn ðə (w)uəld vo:k didən brın ən $\Lambda p$ to no: ə singəl ठin ən az vər zingən (h)wot də si:m (h)Iz zijənz $\mathrm{n} \wedge$ $\theta$ ən bət ə skri:m so: ho: krə:Id dzIm hu:z ðat ðعn mjeəri ðət jə bi: nə:u ətદ:kən o: hi: ठっ:t to kat (h)ər ðعn bət no: krə:Id ppli o: (h)wə:I dzjenz kənعəri wi (h)wot həv ju: əbin misled ə:I w $\Lambda$ ndər tel mi: (h)wpt ə:I zed 
THE GIANTS IN TREÄDES

GRAMFER'S FEÄBLE

(How the steam engine come about.)

Vier, Ä̈r, E'th, Water, wer a-meäde

fire, earth

Good workers, each o'm in his treäde, An' Aïr an' Water wer a match

Vor woone another in a mill;

one

The giant $W$ ater at a hatch,

An' Ä̈r on the windmill hill.

Zoo then, when $W$ ater had a-meäde

Zome money, Aïr begrudg'd his treäde,

An' come by, unaweäres woone night,

An' vound en at his own mill-head,

him

An' cast upon en, iron-tight,

An icy cwoat so stiff as lead.

An' there he wer so good as dead

Vor grindèn any corn vor bread.

Then Water cried to Vier, "Alack!

Look, here be I, so stiff's a log,

Thik fellor Air do keep me back

that

Vrom grindèn. I can't wag a cog.

move

If I, dear Vier, did ever souse

Your nimble body on a house,

When you wer on your merry pranks

Wi' thatch or refters, beams or planks,

Vorgi'e me, do, in pity's neäme,

forgive

Vor 'twerden I that wer to bleäme,

I never wagg'd, though I be'nt cringèn,

Till men did dreve me wi' their engine.

drive

Do zet me free vrom theäse cwold jacket,

this

Vor I myzelf shall never crack it." 
ðə dzə:Iənts in trjedz

gramfərz fjebəl

(hə:u ðə sti:m Indzən k^m əbə:ut)

və:Iər æIr $\varepsilon \theta$ wə:tər wər əmjed

gud wə:rkərz i:t o:m in (h) Iz trjed

ən æIr ən wə:tər wər ə mat

vər (w)u:n ən^ðər in ə mil

ðə dzə:Iənt wo:tər ət ə hat

ən æIr pn ðə wIn(d)mil hil

zu: ðعn (h)wen woitər had əmjed

zəm m^ni ærr bigr $\wedge$ dzd (h)Iz trjed

ən kım bə:I $\Lambda$ nəweərz (w)u:n nə:It

ən və:un(d) on ət (h)IZ o:n milhed

ən kaist əppn ən ə:Iərntə:it

ən ə:Isi kuət sə stIf $ə z$ led

ən ðər hi: wər sə gud əz ded vər grə:In(d)ən عni ka:rn vər bred ðعn wo:tər krə:Id tə və:Iər əlak

luk hiər bi: ə:I sə stıfs ə lpg ðık felər æır də ki(:)p mi: bak

vrəm grə:In(d)ən ə:I ke:nt wag ə kpg

If ə:I diər və:ıər did عvər sə:us

jər nImbəl bpdi pn ə hə:us

(h)wen ju: wər pn jər meri prajks

wi ðat $\int$ ər re:ftərz bi:mz or playks

vargi: mi: du: in pitiz njem

vər twərrdən ə:I ðət wər tə bljem

ə:I nevər wagd ðo: ə:I be:nt krindzən

tIl men did dre:v mi: wi ðər Indzən

du: zet mi: fri: vrəm ðiəs kuəld dzakit

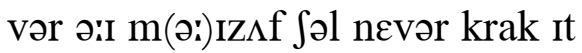


“Well come," cried Vier, “My vo'k ha' meäde

An engine that 'ull work your treäde.

If E'th is only in the mood,

While I do work, to gi'e me food,

I'll help ye, an' I'll meäke your skill

A match vor Mister Aïr's wold mill."

old

"What food," cried E'th, "'ull suit your bwoard?"

"Oh! trust me, I ben't over nice,"

Cried Vier, "an' I can eat a slice

Ov any thing you can avword."

afford

"I've lots," cried E'th, "ov coal an' wood."

"Ah! that's the stuff," cried Vier, "that's good."

Zoo Vier at woonce to Water cried, so, once

"Here, Water, here, you get inside

O' theäse girt bwoiler. Then I'll show

this great

How I can help ye down below,

An' when my work shall woonce begin

You'll be a thousand times so strong,

An' be a thousand times so long

An' big as when you vu'st got in.

first

An' I wull meäke, as sure as death,

Thik fellor Air to vind me breath,

that

An' you shall grind, an' pull, an' dreve,

drive

An' zaw, an' drash, an' pump, an' heave,

thrash

An' get vrom Aïr, in time, I'll lay

A pound, the drevèn ships at sea."

An' zoo 'tis good to zee that might

so

Wull help a man a-wrong'd, to right. 
wel k^m krə:Id və:Iər mə:I vo:k hə mjed ən Indzən ðət $u$ l wərk jər trjed If $\varepsilon \theta$ Iz o:nli In ठə mud (h)wəril ə:I də wərk to gi: mi: fud ə:Il help i: ən əril mjek jər skıl ə mat $\int$ vər mistər æIrz (w)uəld mil (h)wpt fud krə:Id $\varepsilon \theta$ ul su:t jər buərd o: trust mi: ə:I be:nt oivər nəI:S krə:Id və:Iər ən ə:I kən iit ə slə:Is əv عni ठı刀 jə kən əvuərd ə:IV lpts krə:Id $\varepsilon \theta$ əv ko:l ən wud a: ðats ðə st $\Lambda$ krə:Id və:Iər ðats gud zu: və:ır ət (w)u:ns to wo:tər krə:Id hiər wo:tər hiər ju: get Insə:Id ə ðiəs gə:rt bwə:Ilər ðعn ə:Il Jo: hə:u ə:I kən help i: də:un bilo: ən (h)wen mə:I wərrk $\int ə l$ (w)u:ns bigin jəl bi: ə $\theta ə$ ‘uzən(d) tə:Imz sə strpy ən bi: ə $\theta$ ə:uzən(d) tə:Imz sə lpy ən big əz (h)wen jə v $\Lambda$ st gpt In ən ə:I wul mjek $\partial \mathrm{z} \int \mathrm{u}(\mathrm{s}) \partial \mathrm{r}$ əz $\mathrm{d} \varepsilon \theta$ ðık felər æIr to və:In(d) mi: bre $\theta$ ən ju: $\int \partial l$ grə:In(d) ən pul ən dre:v ən ze: ən dra ən $\mathrm{p} \Lambda \mathrm{mp}$ ən he:v ən get vrəm ærr In tə:Im əsil le: ə pə:un(d) ðə dre:vən $\int \mathrm{ips}$ ət si: ən zu: tIz gud tə zi: ðət mə:It wul help ə man əroyd to rə:It 
THE LITTLE WOROLD

MY hwome wer on the timber'd ground

O' Duncombe, wi' the hills a-bound:

Where vew from other peärts did come,

An' vew did travel vur from hwome, far

An' small the worold I did know;

But then, what had it to bestow

But Fanny Deäne so good an' feäir?

'Twer wide enough if she wer there.

In our deep hollow where the zun

Did eärly leäve the smoky tun, chimney-top

An' all the meäds a-growèn dim,

Below the hill wi' zunny rim;

Oh! small the land the hills did bound,

But there did walk upon the ground

Young Fanny Deäne so good an' feäir:

'Twer wide enough if she wer there.

O’ leäte upon the misty plaïn

I staÿ'd vor shelter vrom the raïn,

Where sharp-leav'd ashes' heads did twist

In hufflèn wind, an' driftèn mist,

gusty

An' small the worold I could zee;

But then it had below the tree

My Fanny Deäne so good an' feäir:

'Twer wide enough if she wer there.

An' I've a house wi' thatchen ridge,

Below the elems by the bridge:

Wi' small-peän'd windows, that do look

Upon a knap, an' ramblèn brook;

billock 
ðə litəl wərrdə1

mə:I huəm wər pn ðə tımbərd grə:un(d)

ə dınku:m wi ðə hılz əbə:un(d)

(h)wər vju: vrəm $\Lambda$ ðr pjarts did kım

ən vju: did travəl və:r vrəm huəm

ən sma:l ðə wə:rdəl ə:I did no:

bət $ð \varepsilon n(h) w p t$ had It to bisto:

bət fani diən sə gud ən fjeər

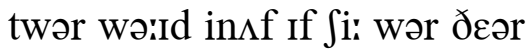

In ə:uər di:p hplər (h)wər ðə z^n

did jərrli liəv ðə smo:ki t $\Lambda$ n

ən a:l ðə miədz əgro:ən dim

bılo: ðə hıl wi zıni rim

o: sma:l ðə lan(d) ðə hilz did bə:un(d)

bət ठər did we:k əppn ðə grə:un(d)

$\mathrm{j} \wedge \mathrm{y}$ fani diən sə gud ən fjeər

twər wəII in $\Lambda$ f If $\int i$ i: wər ðعər

ə ljet əppn ðə misti plæın

ə:I stæId vər $\int \varepsilon l t ə r$ vrəm ðə ræIn

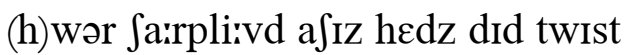

In h^flən win(d) ən driftən mist

ən sma:l ðə wə:rdəl ə:I kud zi:

bət ðعn it had bilo: ðə tri:

mə:I fani diən sə gud ən fjeər

twər wə:Id in $\Lambda$ If $\int \mathrm{i}$ i: wər ठعər

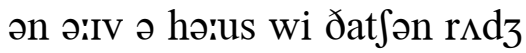

bılo: ði عləmz b(ə:)I ðə br $\Lambda d 3$

wi sma:lpjend windərz ðət də luk

əppn ə nap ən ramblən bruk 
An' small's my house, my ruf is low,

But then who mid it have to show

may

But Fanny Deäne so good an' feäir?

'Tis fine enough if peace is there. 
ən sma:lz mə:I hə:us mə:I r $\Lambda$ f Iz lo:

bət $ฮ \varepsilon n$ hu: mid it hav to Jo:

bət fani diən sə gud ən fjeər

tIz fə:In in $\Lambda$ If piss Iz ðعər 
BAD NEWS

I DO mind when there broke bitter tidèns,

Woone day, on their ears,

one

An' their souls wer a-smote wi' a stroke

As the lightnèn do vall on the woak,

oak

An' the things that wer bright all around em

Seem'd dim drough their tears.

through

Then unheeded wer things in their vingers,

Their grief wer their all.

All unheeded wer zongs o' the birds,

All unheeded the child's perty words,

All unheeded the kitten a-rollèn

The white-threaded ball.

Oh! vor their minds the daylight around em

Had nothèn to show.

Though it brighten'd their tears as they vell, An' did sheen on their lips that did tell,

shine

In their vaïces all thrillèn an' mwoansome,

O' nothèn but woe.

shuddering

But they vound that, by Heavenly mercy,

The news werden true;

wasn't

An' they shook, wi' low laughter, as quick

As a drum when his blows do vall thick,

An' wer eärnest in words o' thanksgivèn,

Vor mercies anew. 
bad nju:z

ə:I də mə:In(d) (h)wen ðər bro:k bitər tə:Idənz (w)u:n de: pn ðər iərz

ən ठər so:lz wər əsmo:t wi ə stro:k az ðə lə:itnən də va:l pn ðə (w)uək ən ठə ठıyz ðət wər brə:It a:l ərə:un(d) əm si(:)md dim dru: ðər tiərz

ðعn $\Lambda$ nhi:dıd wər ðınz In ðər vingərz ðər gri:f wər ðər a:l a:l $\Lambda$ nhi:did wər zpyz ə ðə bə:rdz

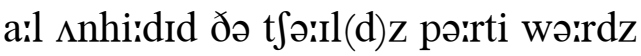
a:l $\Lambda$ nhi:did ðə kitən əro:lən ðə (h)wə:Itdredid ba:l

o: vər ðər mə:In(d)z ðə de:lə:it ərə:un(d) əm had $n \Lambda \theta ə n$ to $\int o:$ ðo: It brə:Itənd ðər tiərz əz ðe: vel ən did Ji:n pn ðər lips ðət did tel In ðər væIsız a:l Orilən ən muənsəm ə n $\wedge \theta$ əən bət wo:

bət ðe: və:un(d) ðət b(ə:)I hعvənli mə:rsi ðə nju:z wə:rdən tru: ən ðe: Suk wi lo: le:ftər əz kwik əz ə $\operatorname{dr} \Lambda \mathrm{m}$ (h)wen (h)Iz blo:z də va:l $\theta \mathrm{rk}$ ən wər ja:rnist In wə:rdz ə Өajksgivən vər mərrsiz ənju: 
THE TURNSTILE

AH! sad wer we as we did peäce

The wold church road, wi' downcast feäce, old

The while the bell, that mwoan'd so deep

Above our child a-left asleep,

Wer now a-zingèn all alive

Wi' tother bells to meäke the vive.

But up at woone pleäce we come by,

one

'Twer hard to keep woone's two eyes dry;

On Steän-cliff road, 'ithin the drong,

lane

Up where, as vo'k do pass along,

folk

The turnèn stile, a-païnted white,

Do sheen by day an' show by night.

shine

Vor always there, as we did goo

To church, thik stile did let us drough,

Wi' spreadèn eärms that wheel'd to guide

that, through

Us each in turn to tother zide.

An' vu'st ov all the train he took

first

My wife, wi' winsome gait an' look;

An' then zent on my little maï,

daughter

A-skippèn onward, overjaÿ'd

To reach ageän the pleäce o' pride,

Her comely mother's left han' zide.

An' then, a-wheelèn roun', he took

On me, 'ithin his third white nook.

An' in the fourth, a-sheäkèn wild,

He zent us on our giddy child.

son

But eesterday he guided slow

My downcast Jenny, vull o' woe,

An' then my little maid in black,

A-walkèn softly on her track; 
ðə tə:rnstə:Il

a: sad wər wi: $\partial z$ wi: did pjes ðə (w)uəld tfərrt $\int$ ro:d wi dərunkaist fjes ðə (h)wə:Il ðə bel ðət muənd sə di:p

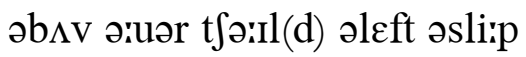
wər nə:u əzIngən a:l ələ:IV

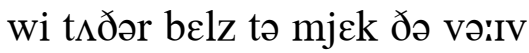
bət $\Lambda \mathrm{p}$ ət (w)uin pljes wi: kım bə:I twər ha:rd tə ki(:)p (w)u:nz tu: ə:Iz drə:I pn stiənklıf ro:d ıðı ðə dron $\Lambda \mathrm{p}$ (h)wər əz vo:k də pais əlpy ðə tə:rnən stə:Il əpæintId (h)wə:It

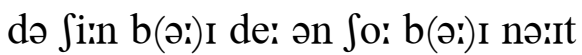
vər a:lwe:z ðcər əz wi: did gu: to t $\int$ ərrt $\int \mathrm{Ik}$ stə:Il did let əs dru: wi spredən ja:rmz ðət (h)wi:ld to gə:Id əs i:t $\int$ in tə:rn to t $\Lambda$ ðər zə:Id ən vıst əv a:l ðə træIn hi: tuk mə:I wə:If wi winsəm gæit ən luk ən ðعn zent pn mə:I litəl mæid əskipən pn(w)ərd sivərdzæid to riit $\int$ əgjen ठə pljes ə prə:Id (h)ər kımli mıðərz left han zə:Id ən ठعn ə(h)wi:lən rə:un hi: tuk pn mi: ıðın (h)Iz ðə:rd (h)wərit nuk ən In ðə fuər $\theta$ ə $j$ jekən wə:Il(d) hi: zent əs pn ə:uər gidi tfə:Il(d) bət iistorde: hi: gəiIdId slo: mə:I də:unka:st dz๕ni vol ə wo: ən ðعn mə:I litəl mæid in blak əwe:kən $\operatorname{spf}(\mathrm{t})$ li pn (h)ər trak 
An' after he'd a-turn'd ageän,

To let me goo along the leäne,

He had noo little bwoy to vill

His last white eärms, an' they stood still.

arms 
ən ع:tər hi:d ətə:rnd əgjen

tə let mi: gu: əlpy ðə ljen

hi: had nu: litəl bwə:I to vil

(h)Iz le:st (h)wə:It ja:rmz ən ðe: stud stıl 
'TwER good what Meäster Collins spoke

O' spite to two poor spitevul vo'k, folk

When woone twold tother o' the two one

"I be never the better vor zeèn o' you."

If soul to soul, as Christians should,

Would always try to do zome good,

"How vew," he cried, "would zee our feäce

A-brighten'd up wi' smiles o' greäce,

An' tell us, or could tell us true,

I be never the better vor zeèn o' you."

A man mus' be in evil ceäse case (plight)

To live 'ithin a land o' greäce,

Wi' nothèn that a soul can read

O' goodness in his word or deed;

To still a breast a-heav'd wi' sighs,

Or dry the tears o' weepèn eyes;

To staÿ a vist that spite ha' wrung,

Or cool the het ov anger's tongue:

fist, clenched

Or bless, or help, or gi'e, or lend; beat

Or to the friendless stand a friend, give

An' zoo that all could tell en true, so, him

"I be never the better vor zeèn o' you."

Oh! no, mid all o's try to spend

Our passèn time to zome good end, An' zoo vrom day to day teäke heed,

By mind, an' han', by word or deed;

To lessen evil, and increase

The growth o' righteousness an' peäce,

A-speakèn words o' lovèn-kindness,

Openèn the eyes o' blindness; 
ðə betər vər zi:ən ə ju:

twər gud (h)wpt mja:stər kplinz spo:k

ə spə:it to tu: $\mathrm{pu}($ :) $)$ r spə:itvul vo:k

(h)wen (w)u:n tuəld tムðər ə ðə tu:

ə:I bi: nevər ðə betər vər zi:ən ə ju:

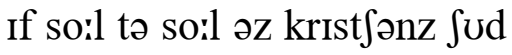

wud a:lwe:z tra:I to du: z^m gud

hə:u vju: hi: krə:Id wod zi: ə:uər fjes

əbrə:Itənd $\Lambda p$ wi smə:Ilz ə grjes

on tel əs ar kud tel əs tru:

ə:I bi: nevər ðə betər vər zi:ən ə ju:

ə man $\mathrm{m} \Lambda \mathrm{s}$ bi: In iivəl kjes

tə liv IðIn ə lan(d) ə grjes

wi n^Өən ðət ə so:l kən ri:d

ə gudnis in (h)Iz wərrd or di:d

to stil ə brest əhiivd wi sə:Iz

ar drə:I ðə tiərz ə wi:pən ə:Iz

tə stæi ə vist ðət spə:It hə ruy

ar ku:l ठə het əv aygərz $\mathrm{t} \Lambda \mathrm{y}$

ar bles ar help ar gi: ar len(d)

ar tə ðə fren(d)lis $\operatorname{stan}(\mathrm{d})$ ə fren(d)

ən zu: ðət a:l kud tel ən tru:

ə:I bi: nevər ðə betər vər zi:ən ə ju:

o: no: mid a:l o:s trəiI to $\operatorname{spen}(\mathrm{d})$

ə:uər pa:sən tə:Im to $\mathrm{z} \Lambda \mathrm{m}$ gud $\varepsilon \mathrm{n}(\mathrm{d})$

ən zu: vrəm de: to de: tjek hi:d

b(ə:)I mə:In(d) ən han b(ə:)I wə:rd ər di:d

to lesən iivəl ən(d) Inkriis

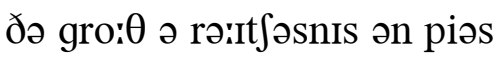

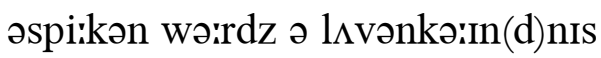

o:bənən ði ə:Iz ə blə:In(d)nIs 
Helpèn helpless strivers' weakness,

Cheerèn hopeless grievers' meekness,

Meäken friends at every meetèn,

Veel the happier vor their greetèn;

Zoo that vew could tell us true,

"I be never the better vor zeèn o' you."

No, let us even try to win

Zome little good vrom sons o' sin,

An' let their evils warn us back

Vrom teäkèn on their hopeless track,

Where we mid zee so clear's the zun

may

That harm a-done is harm a-won,

An' we mid cry an' tell em true,

"I be even the better vor zeèn o' you." 
helpən helplis strə:Ivərz wi:knis

t fiərən ho:plis gri:vərz mi:knis

mjekən fren(d)z at $\varepsilon v r i$ mi:tən

vi:l ðə hapiər vər ðər gritəon

zu: ðət vju: kud tel əs tru:

ə:I bi: nevər ðə betər vər zi:ən ə ju:

no: let əs iivən trə:I to win

z $\Lambda$ litəl gud vrəm s $\Lambda \mathrm{nz}$ ə sin

ən let ðər iivəlz wa:rn əs bak

vrəm tjekən pn ðər ho:plis trak

(h)wər wi: mId zi: sə kliərz ðə z^n

ðət ha:rm əd $\Lambda$ n Iz ha:rm əwın

ən wi: mid krə:I on tel əm tru:

ə:I bi: iivən ðə betər vər zi:ən ə ju: 
PITY

Good Meäster Collins! aye, how mild he spoke

Woone day o' Mercy to zome cruel vo'k.

one, folk

"No, no. Have Mercy on a helpless head,

An' don't be cruel to a zoul," he zaid.

"When Babylon's king woonce cast 'ithin

once

The viery furnace, in his spite, fiery

The vetter'd souls whose only sin

Wer praÿer to the God o' might,

He vound a fourth, 'ithout a neäme,

A-walkèn wi' em in the fleäme.

An' zoo, whenever we mid hurt, so, may

Vrom spite, or vrom disdaïn,

A brother's soul, or meäke en smert

bim

Wi' keen an' needless païn,

Another that we midden know

may not

Is always wi' en in his woe.

Vor you do know our Lord ha' cried,

'By faïth my bretheren do bide

In me the livèn vine,

As branches in a livèn tree;

Whatever you've a-done to mine

Is all a-done to me.'

Oh! when the new-born child, the e'th's new guest,

earth's

Do lie an' heave his little breast,

In pillow'd sleep, wi' sweetest breath

O’ sinless days drough rwosy lips a-drawn;

through

Then, if a han' can smite en in his dawn

O' life to darksome death,

Oh! where can Pity ever vwold

Her wings o' swiftness vrom their holy flight,

To leäve a heart o' flesh an' blood so cwold

At such a touchèn zight? 
piti

gud mjaistər kplınz æi hə:u mə:ıld hi: spo:k

(w)uin de: ə mə:rsi to zəm kruiəl vo:k

no: no: hav mə:rsi on ə helplis hed

on do:nt bi: kruiəl tu $ә$

(h)wen babılpnz kıj (w)u:ns kaist ıðın

ðə və:ıəri fə:rnis in (h)IZ spə:It

ðə vetərd so:lz hu:z o:nli sin

wər præiər tə ðə gpd ə mə:It

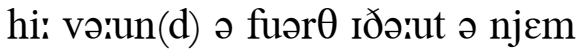

әwع:kən wi əm in ðə fljem

วn zu: (h)wenevər wi: mid hərrt

vrəm spə:it or vrəm disdæin

ə brıðərz so:l ər mjek ən smə:rt

wi ki:n on ni:dlıs pæin

ən^ðər ðət wi: midən no:

Iz ailwe:z wi on in (h)Iz wo:

vər ju: də no: ə:uər laird hə krə:Id

b(ə:)I fæi $\theta$ mə:i breðərən də bə:Id

In mi: ðə livən və:In

əz braint $\int \mathrm{Iz}$ in ə livən tri:

(h)wotevər jəv əd $\Lambda \mathrm{n}$ tə mə:In

Iz a:l əd $\Lambda \mathrm{n}$ tə mi:

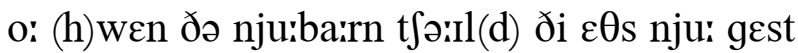

də lə:I ən he:v (h)Iz litəl brest

In pilərd sli:p wi swi(:)tist bre $\theta$

ə sinlis de:z dru: ruəzi lips ədre:n

ðعn If ə han kən smə:It ən In (h)IZ de:n

ə lə:If tə da:rksəm de $\theta$

o: (h)wər kən piti عvər vuəld

(h)ər winz ə swif(t)nis vrəm ðər ho:li flə:It

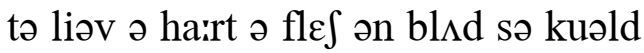

ət sit $\int$ t $\Lambda \mathrm{t} \int \partial n$ zə:It 
An' zoo mid meek-soul'd Pity still

Be zent to check our evil will,

An' keep the helpless soul from woe,

An' hold the hardened heart vrom sin,

Vor they that can but mercy show

Shall all their Father's mercy win." 
ən zu: mid mi:kso:ld piti stil bi: zent to tfek ə'uər iivəl wil ən ki(:)p ठə helplıs so:l vrəm wo:

ən huəld ðə ha:rdənd hairt vrəm sin vər ðe: ðət kan bət mə:rsi Jo:

fəl a:l ðər fe:ðərz mə:rsi win 
JOHN BLOOM IN LON’ON

(All true.)

JOHN BLOOM he wer a jolly soul,

A grinder o' the best o' meal,

Bezide a river that did roll,

Vrom week to week, to push his wheel.

His flour wer all a-meäde o' wheat;

An' fit for bread that vo'k mid eat;

folk may

Vor he would starve avore he'd cheat.

"'Tis pure," woone woman cried;

one

"Aye, sure," woone mwore replied;

"You'll vind it nice. Buy woonce, buy twice,"

once

Cried worthy Bloom the miller.

Athirt the chest he wer so wide across

As two or dree ov me or you, three

An' wider still vrom zide to zide,

An' I do think still thicker drough.

through

Vall down, he coulden, he did lie

When he wer up on-zide so high

As up on-end or perty nigh.

"Meäke room," woone naïghbour cried;

“"Tis Bloom," woone mwore replied;

"Good morn t'ye all, bwoth girt an' small,"

great

Cried worthy Bloom the miller.

Noo stings o' conscience ever broke

His rest, a-twitèn o'n wi' wrong,

Zoo he did sleep till mornèn broke, reproaching bim

An' birds did call en wi' their zong. 
dzan blu:m in 1^nən

a:l tru:

dzan blu:m hi: wər a dzpli so:l

ə grə:In(d)ər ə ðə best ə mi:l

bizə:Id ə rivər ðət did ro:l

vrəm wi(:)k to wi(:)k to pus (h)Iz (h)will

(h)Iz flə:uər wər a:l əmjed ə (h)witt

ən fit vər bred ðət vo:k mId i:t

vər hi: wod stairv əvuər hi:d t fiit

tIz pju(:)ər (w)u:n wumən krə:Id

æI $\int \mathrm{u}(\mathrm{i}) \partial r(\mathrm{w}) \mathrm{u}$ :n muər riplə:Id

jəl və:In(d) It nər:s bə:I (w)u:ns bə:I twər:s

krə:Id wə:rði blu:m ðə milər

əðə:rt ðə t $\int \varepsilon s t$ hi: wər sə wə:Id

əz tu: ər dri: əv mi: ər ju:

ən wə:Idər strl vrəm zə:Id tə zə:Id

ən ə:I də ðınk stıl $\theta$ Ikər dru:

va:l də:un hi: kudən hi: did lə:I

(h)wen hi: wər $\Lambda$ p pnzə:Id sə hə:I

əz $\Lambda p$ pnen(d) ar pərrti nə:I

mjek ru:m (w)u:n næibər krə:Id

tIz blu:m (w)u:n muər riplə:Id

gud ma:rn tji: a:l buəð gə:rt ən sma:l

krə:Id wə:rði blu:m ðə milər

nu: stinz ə kpnfəns evər bro:k

(h)IZ rest ətwə:Itən o:n wi roy

zu: hi: did sli:p til marnən bro:k

ən bə:rdz did ka:l ən wi ðər zpy 
But he did love a harmless joke,

An' love his evenèn whiff o' smoke,

A-zittèn in his cheäir o' woak.

oak

"Your cup," his daughter cried;

"Vill'd up," his wife replied;

"Aye, aye; a drap avore my nap,"

Cried worthy Bloom the miller.

When Lon'on vok did meäke a show

O' their girt glassen house woone year, great, one

An' people went, bwoth high an' low,

To zee the zight, vrom vur an' near,

"O well," cried Bloom, "why I've a right

So well's the rest to zee the zight;

I'll goo, an' teäke the rail outright."

forthwith

"Your feäre," the booker cried;

"There, there," good Bloom replied;

fare

"Why this June het do meäke woone zweat,"

beat

Cried worthy Bloom the miller.

Then up the guard did whissle sh'ill,

An' then the engine pank'd a-blast,

An' rottled on so loud's a mill,

Avore the traïn, vrom slow to vast.

An' oh! at last how they did spank

By cuttèn deep, an' high-cast bank

The while their iron ho'se did pank.

pant

"Do whizzy," woone o'm cried;

"I'm dizzy," woone replied;

"Aye, here's the road to hawl a lwoad,"

Cried worthy Bloom the miller. 


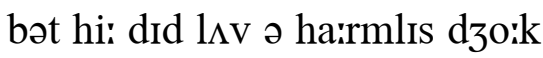

ən $\mathrm{h} \Lambda \mathrm{v}$ (h)Iz i:vmən (h)wif ə smo:k

əzitən In (h) Iz t $\int \varepsilon ə r$ ə (w) uək

jər kıp (h)Iz de:tər krə:Id

vild $\Lambda p$ (h)IZ wə:If riplə:Id

æI æI ə drap əvuər mə:I nap

krə:Id wə:rði blu:m ðə mılər

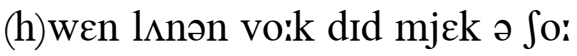

ə ðər gərrt glaisən hərus (w)uin jiər

ən pi:pəl went buəð hə:I ən lo:

tə zi: ðə zə:It vrəm vərr ən niər

o: wel krə:Id blu:m (h)wə:I əiIV ə rə:It

sə welz ðə rest tə zi: ðə zə:It

ə:Il gu: ən tjek ðə ræIl ə:utrə:It

jər fjeər ðə bukər krə:Id

ðعər ðعər gud blu:m riplə:Id

(h)wə:I ðIs dzuin het də mjek (w)u:n zwet

krə:Id wə:rði blu:m ðə milər

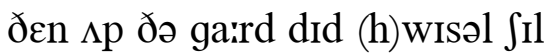

ən ठعn ði indzən paykt ə blaist

ən rotəld pn sə lərudz ə mil

əvuər ठə træIn vrəm slo: tə vaist

ən o: ət le:st hə:u ðe: did spayk

b(ə:)I kıtən di:p ən hərikaist bayk

ðə (h)wә:Il ðər ә:ıәrn hps did payk

də (h)wizi (w)u:n o:m krə:Id

ə:Im dızi (w)u:n riplə:Id

æı hiərz ðə ro:d tə ha:l ə luəd

krə:Id wə:rði blu:m ðə mılər 
In Lon'on John zent out to call

A tidy trap, that he mid ride

might

To zee the glassen house, an' all

The lot o' things a-stow'd inside.

"Here, Boots, come here," cried he, "I'll dab

A sixpence in your han' to nab

Down street a tidy little cab."

"A feäre," the boots then cried;

fare (passenger)

"I'm there," the man replied.

"The glassen pleäce, your quickest peäce,"

Cried worthy Bloom the miller.

The steps went down wi' rottlèn slap,

The zwingèn door went open wide:

Wide? no; vor when the worthy chap

Stepp'd up to teäke his pleäce inside,

Breast-foremost, he wer twice too wide

Vor thik there door. An' then he tried

that

To edge in woone an' tother zide.

one

"'Twont do," the drever cried;

driver

"Can't goo," good Bloom replied;

"That you should bring theäse vooty thing!"

this paltry

Cried worthy Bloom the miller.

"Come," cried the drever. "Pay your feäre.

fare

You'll teäke up all my time, good man."

"Well," answer'd Bloom, "to meäke that square,

You teäke up me, then, if you can."

"I come at call," the man did nod.

"What then?" cried Bloom, "I han't a-rod,

ridden

An' can't in thik there hodmadod."

contraption

"Girt lump," the drever cried;

great

"Small stump," good Bloom replied;

"A little mite, to meäke so light,

O’ jolly Bloom the miller." 
In l^nən dzan zent ərut to ka:l

ə tə:Idi trap ðət hi: mid rə:Id

to zi: ðə glaisən hə:us ən a:l

ðə lpt ə ðınz əsto:d Insə:Id

hiər bu:ts k^m hiər krə:Id hi: ə:Il dab

a sıkspəns in jər han to nab

də:un stri:t ə tə:Idi litəl kab

ə fjeər ðə bu:ts ðعn krə:Id

ə:Im ðعər ðə man riplə:Id

ðə gla:sən pljes jər kwıkıst pjes

krə:Id wə:rði blu:m ðə milər

ðə steps went də'un wi rotlən slap

ðə zwinən duər went o:bən wə:Id

wə:Id no: vər (h)wen ðə wə:rði tfap

stept $\Lambda p$ to tjek (h)IZ pljes Insərid

brest fuərmo:st hi: wər twəIs tu: wə:Id

vər ðIk ðعər duər ən ðعn hi: trə:Id

tu $\varepsilon d_{3}$ In (w)uin ən t^ðər zə:Id

twu(:)nt du: ðə dre:vər krə:Id

ke:nt gu: gud blu:m riplə:Id

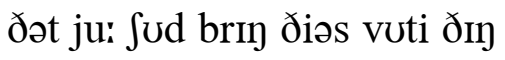

krə:Id wə:rði blu:m ðə milər

k^m krə:Id ðə dre:vər pæi jər fjeər

jəl tjek $\Lambda$ p a:l mə:I tə:Im gud man

wel e:nsərd blu:m to mjek ðat skweər

ju: tjek $\Lambda p$ mi: ðعn If jə kan

ə:I kım ət ka:l ðə man did npd

(h)wpt ðen krə:Id blu:m ə:I hant ərpd

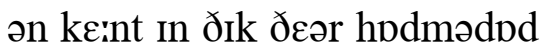

gə:rt lımp ðə dre:vər krə:Id

sma:l stımp gud blu:m riplə:Id

ə litəl mə:It tə mjek sə lə:it

ə dz̧pli blu:m ðə milər 
"You'd best be off now perty quick,"

Cried Bloom, “an' vind a lighter lwoad,

Or else I'll vetch my voot, an' kick

The vooty thing athirt the road."

across

"Who is the man?" they cried, "meäke room."

"A halfstarv'd Do'set man," cried Bloom;

"You be?" another cried;

“Hee! Hee!" woone mwore replied.

one

"Aye, shrunk so thin, to bwone an' skin,"

Cried worthy Bloom the miller. 
ju:d best bi: pf nə:u pərrti kwik

krə:Id blu:m ən və:In(d) ə lə:Itər luəd

ar els ə:Il vet $\int$ mə:I vut ən kık

ðə vuti ðın əðə:rt ðə ro:d

hu: Iz ðə man ðe: krə:Id mjєk ru:m

ə he:fsta:rvd dosət man krə:Id blu:m

jə bi: ən^ðər krə:Id

hi: hi: (w)u:n muər riplə:Id

æI $\int \mathrm{r} \Lambda$ jk sə ठın tə buən ən skın

krə:Id wə:rði blu:m ðə milər 
"COME on. Be sprack, a-laggèn back."

burry up

"Oh! be there any cows to hook?"

"Lauk she's afraid, a silly maïd."

Lord

"Cows? No, the cows be down by brook."

"O here then, oh! here is a lot."

"A lot o" what? what is it? what?"

"Why blackberries, as thick

As ever they can stick."

"I've dewberries, oh! twice

As good as they; so nice."

"Look here. Theäse boughs be all but blue

these

Wi' snags."

sloes

"Oh! gi'e me down a vew."

low-growing blackberries

"Come here, oh! do but look."

"What's that? what is it now?"

"Why nuts a-slippèn shell."

"Hee! hee! pull down the bough."

"I wish I had a crook."

"There zome o'm be a-vell."

of them, fallen

(One sings)

"I wish I was on Bimport Hill

I would zit down and cry my vill."

"Hee! hee! there's Jenny zomewhere nigh,

A-zingèn that she'd like to cry."

(Jenny sings)

"I would zit down and cry my vill

Until my tears would dreve a mill."

drive

"Oh! here's an ugly crawlèn thing,

A sneäke." "A slooworm; he wont sting."

slow-worm (snake-like lizard)

"Hee! hee! how she did squal an' hop,

A-spinnèn roun' so quick's a top.” 
ə lpt ə mæidənz ərınən ðə vi:l(d)z

kım pn bi: sprak əlagən bak

o: bi: ðər عni kə'uz tə huk lo:k Si:z əfræid ə sili mæId kə'uz no: ðə kə:uz bi: də'un b(ə:)I bruk o: hiər ðعn o: hiər IZ ə lpt ə lpt a (h)wpt (h)wpt Iz It (h)wpt (h)wə:I blakbəriz əz $\theta \mathrm{rk}$ əz عvər ðe: kən stık ə:Iv djuibəriz o: twər:s əz gud əz ðe: so: nəI:s luk hiər điəs bə:uz bi: ail bət blu: wi snagz o: gi: mi: də:un ə vju:

kım hiər o: du: bət luk (h)wpts ðat (h)wpt Iz It nə:u

(h)wə:I n $\Lambda$ ts əslipən $\int \varepsilon l$ hi: hi: pul də:un ðə bə:u ə:I WIS ə:I had ə kruk ðعər z^m o:m bi: əvعl (One sings)

ว:I WI $\partial: I$ wəz pn bimpairt hil ə:I wud zit də:un ən(d) krə:I mə:I vil hi: hi: ðعərz dzeni zムm(h)wər nə:I əzıngən ðət fiid lə:ık tə krə:I (Jenny sings)

ə:I wud zit də:un ən(d) krə:I mə:I vil $\Lambda$ ntıl mə:I tiərz wud dre:v ə mil o: hiərz ən $\Lambda$ gli kre:lən ðıy ə snjek ə sluiwərrm hi: wu(:)nt stın hi: hi: hə:u fi: did skwa:l ən hpp əspinən rə:un sə kwiks ə tpp 
"Look here, oh! quick, be quick."

"What is it? what then? where?"

"A rabbit." "No, a heäre."

"Ooh! ooh! the thorns do prick."

"How he did scote along the ground

race

As if he wer avore a hound."

"Now mind the thistles." "Hee, hee, hee,

Why they be knapweeds." "No." "They be."

"I've zome'hat in my shoe."

"Zit down, an' sheäke it out."

"Oh! emmets, oh! ooh, ooh,

ants

A-crawlèn all about."

"What bird is that, O harken, hush.

How sweetly he do zing."

"A nightingeäle." "La! no, a drush.”

thrush

"Oh! here's a funny thing."

"Oh! how the bull do hook,

An' bleäre, an' fling the dirt."

bellow

"Oh! wont he come athirt?"

across

"No, he's beyond the brook."

"O lauk! a hornet rose

Lord

Up clwose avore my nose."

"Oh! what wer that so white

Rush'd out o' thik tree's top?"

that

"An owl." "How I did hop,

How I do sheäke wi’ fright."

"A musheroom." "O lau!

A twoadstool! Pwoison! Augh."

"What's that, a mouse?"

$$
\text { "O no, }
$$

Teäke ceäre, why 'tis a shrow."

shrew

"Be sure dont let en come

it

An' run athirt your shoe: 
luk hiər o: kwık bi: kwık

(h)wpt Iz it (h)wpt ðعn (h)weər

ə rabit no: ə hjeər

u: u: ðə ða:rnz də prik

hə;u ə did skə;ut əlpy ðə grə:un(d)

əz If ə wər əvuər ə hə:un(d)

nə:u mə:In(d) ðə ðısəlz hi: hi: hi:

(h)wə:I ðe: bi: napwi:dz

no: ðe: bi:

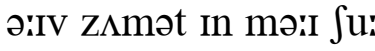

zit dərun ən Sjek it ərut

o: emots o: u: u:

əkre:lən ail əbə:ut

(h)wpt bə:rd Iz ðat o: harkən $\mathrm{h} \Lambda \int$

hə:u swi(:)tli ə də zIn

ə nə:Itingjel la no: ə $\mathrm{dr} \Lambda \int$

o: hiərz ə fıni ðIn

o: hə:u ðə bul də huk

ən bljeər ən flın ðə dərrt

o: wu(:)nt hi: k^m əðə:rt

no: hi:z bijand ðə bruk

o: lo:k a ha:rnit ro:z

$\Lambda p$ kluəs əvuər mə:I no:z

o: (h)wpt wər ðat sə (h)wə:It

rs $\Lambda$ t ərut a drk tri:z top

ən ə:ul hə:u ə:I did hpp

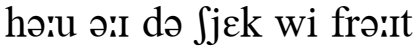

ə $\mathrm{m} \Lambda$ Jəru:m o: lo:

ə tuədstuil pwə:Izən o:

(h)wpts ðat ə mə:us

o: no:

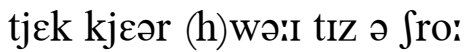

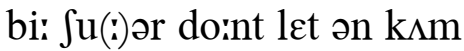

ən rın əðə:rt jər $\int u$ : 
He'll meäke your voot so numb

That you wont veel a tooe."

"Oh! what wer that so loud

A-rumblèn?" "Why a clap

O' thunder. Here's a cloud

O' raïn. I veel a drap."

"A thunderstorm. Do raïn.

Run hwome wi' might an' maïn.”

"Hee! hee! oh! there's a drop

A-trickled down my back. Hee! hee!"

"My head's as wet's a mop."

"Oh! thunder," "there's a crack. Oh! Oh!"

"Oh! I've a-got the stitch, Oh!"

"Oh! I’ve a-lost my shoe, Oh!"

“There's Fanny into ditch, Oh!"

"I'm wet all drough an' drough, Oh!"

through and through 
hi:l mjek jər vut sə $\mathrm{n} \wedge \mathrm{m}$

ðət jə wu(:)nt vi:l ə tu:

o: (h)wpt wər ðat sə lə:ud

ərımblən (h)wə:I a klap

ə $\theta$ ndər hiərz ə klə:ud

ə ræIn ə:I vi:l ə drap

ə $\theta \Lambda$ ndərsta:rm də ræIn

rın huəm wi məit ən mæin

hi: hi: o: ðərz ə drap

atrikəld də:un mə: bak hi: hi:

mə:I hedz əz wets ə mpp

o: $\theta \Lambda$ ndər ðərz ə krak o: o:

o: ə:IV əgpt ðə stit 0 :

o: ə:IV əlpst mə:I $\int u:$ o:

ðərz fani intə dit 0 :

ə:Im wet a:l dru: ən dru: o: 



\section{TEXTUAL NOTES}

Emendations in wording are normally made only where there is support (not recorded here) from at least one version other than 1879; emendations in punctuation are made, with or without support from other versions, where the punctuation of 1879 would be likely to impede understanding. References to the poems are given by page and line number, the complete line being quoted for ease of reference.

VULL A MAN

40/28 An' of en at my own wits' end, end,] . 1879

\section{NAÏGHBOUR PLAŸMEÄTES}

44/25 Along the geärden wall do show geärden] geärdèn 1879

\section{THE LARK}

48/7 The orts a-left behin' by cows, cows,] . 1879

THE TWO CHURCHES

50/4 Noke,] . 1879

GRAMMER A-CRIPPLED

74/11 An' birds' gaÿ sounds

birds'] bird's 1879

74/19 The woaken chair's vor you to vill, The] To 1879

\section{THE CASTLE RUINS}

78/8 That wer a-gone avore we come, come,] . 1879 
ECLOGUE: JOHN, JEALOUS AT SHROTON FEÄIR

82/14 Heigh! there, then, Joey, ben't we proud!

proud!] no punctuation 1879

\section{GOOD NIGHT}

98/21 Under the zunlight glow'd,

glow'd,] . 1879

\section{WENT HWOME}

100/9 Wi' smeechy doust from heel to tooe,

tooe,] . 1879

\section{CHILDERN'S CHILDERN}

104/23 Be jaÿ or païn, be païn or jä̈?

jaй?] . 1879

106/3 Be jaÿ or païn, be païn or jaÿ?

jä̈?] . 1879

\section{COME}

$110 / 7$ Vor to quicken love anew?

anew?] . 1879

\section{THE PILLAR'D GEÄTE}

124/16 The house, below a dark-blue sky, sky,] . 1879

126/2 Spent all her store an' wealth, an' died; died;] , 1879

\section{ZUMMER STREAM}

130/11 My zun-out-measur'd time's agone. zun-out-measur'd] zun out-measur'd 1879 
LINDA DEÄNE

132/8 An' snow-white lilies' noddèn heads, lilies'] lilies 1879

\section{THE LOVE CHILD}

152/7 The white deäisies, a-spread in a sheet, sheet,] . 1879

152/18 Then "You don't seem a-born an' a-bred," Then "You] "Then you 1879

WHAT JOHN WER A-TELLÈN HIS MIS'ESS . . .

164/last line How time do run! How years do roll! roll!] no punctuation 1879

ECLOGUE: RACKETÈN JOE

$170 /$ last line Wowh! wow! wow!] no punctuation 1879

TO ME

180/9 Kept all the quiv'rèn leaves unshown to me. me.] , 1879

182/7 Zoo, sweet ov unzeen things mid be the sound, the] omitted 1879

THE LEW O' THE RICK

186/29 Or under me, an' though vull grown Or] O' 1879

\section{TOKENS}

190/17 That she'd a-liv'd, an' liv'd vor me, That] Thät 1879 
TWEIL

194/20 Do dreatèn mwost our tweilsome life, dreaten] dreatèn 1879

FANCY

196/9 In weästèn life's slow-beätèn track.

In] In' 1879

196/21 Vor warm-aïr'd meäds o' new mow'd hä̈, haÿ,] . 1879

196/ last line Ov me'th an' smiles, an' warmth an' light. meth] mè'th 1879

THE ZILVER-WEED

230/7 That then wer all the maïdens' ceäre, maïdens'] maïden's 1879

THE FANCY FEÄIR AT MAÏDEN NEWTON

244/9 An' all to meäke, vor childern's seäke, meäke] meake 1879

\section{THINGS DO COME ROUND}

246/5 Did hang the raïn-drop's quiv'rèn ball; drop's] drops 1879

246/19 An' thought on times, long years agoo, agoo,] . 1879

248/4 About our little farm below, below,] . 1879

248/last line How He in time do bring things round! round!] ; 1879 


\section{I'M OUT O' DOOR}

252/last line An' ivy-stems do whip the wall, wall,] . 1879

\section{GRIEF AN' GLADNESS}

256/9 A-flutt'rèn at their back,"

back,] . 1879

256/24 Lik' darkness at a happy dawn,"

dawn,] . 1879

\section{SLIDÈN}

260/15 A-stannèn still, come wind, blow on, still,] . 1879

NOT GOO HWOME TO-NIGHT

274/27 Behind the elem's neäked lim' lim'] lim'. 1879

\section{SHAFTESBURY FEÄIR}

282/3 So bright to me down miles below, below,] . 1879

282/5 Did brighten up his hill's high breast, breast,] . 1879

282/9 Awaÿ so feäir, feäir,] . 1879

\section{THE BEÄTEN PATH}

288/14 A jaÿ to souls they left to weep

A jaÿ] A-jaÿ 1879 
MY LOVE IS GOOD

296/19 Still feäirer out o' door, O,

$\mathrm{O},] \sim .1879$

\section{THE DO'SET MILITIA}

306/7 An' Jeäne do write, an' bag o' Joe

bag] brag 1879

\section{KINDNESS}

320/4 The prowlèn owls the mouse below, below,] . 1879

DANIEL DWITHEN, THE WISE CHAP $326 / 20$ Ov half the wild outlandish things outlandish] outlandïsh 1879

\section{TURNÈN THINGS OFF}

330/last line Her needle, at her vinger's end, end,] . 1879

\section{THE GIANTS IN TREÄDES}

334/6 An' Aïr an' Water wer a match

Water] , 1879

a match] a-match 1879

\section{THE LITTLE WOROLD}

338/20 Where sharp-leav'd ashes' heads did twist ashes'] ashès' 1879

\section{THE TURNSTILE}

344/4 The while the bell, that mwoan'd so deep bell] bells 1879 


\section{THE BETTER VOR ZEÈN O' YOU}

350/1 Helpèn helpless strivers' weakness, strivers'] striver's 1879

$350 / 7$ No, let us even try to win

No stanza break before this line 1879

\section{JOHN BLOOM IN LON'ON}

$356 / 15$ As two or dree ov me or you, you,] . 1879

358/18 Cried worthy Bloom the miller. miller.] , 1879

360/23 "Come," cried the drever. "Pay your feäre. feäre.] no punctuation 1879

$362 / 5$ "Who is the man?" they cried, "meäke room." room.] , 1879

\section{A LOT O' MAÏDENS A-RUNNÈN THE VIELDS}

364/4 "Lauk she's afraïd, a silly maïd." maïd.] , 1879

366/4 "Ooh! ooh! the thorns do prick." prick.] , 1879

366/8 Why they be knapweeds." "No." "They be."

Two lines, divided after knapweeds 1879

366/last line An' run athirt your shoe: shoe:] no punctuation 1879 



\section{APPENDIX: A SUMMARY OF SECTIONS 7 AND 8 OF WBPG}

This summary gives only the conclusions reached, usually omitting the arguments leading to those conclusions and the comparisons with neighbouring districts. Addenda to the original guide are enclosed in curly brackets. Vowels are arranged according to Wells's classification in his Accents of English (1.xviii-xix), reproduced below.

\begin{tabular}{|c|c|c|c|c|}
\hline RP & $\begin{array}{l}\text { Gen } \\
\text { Am }\end{array}$ & No & KEYWORD & Examples \\
\hline I & I & 1. & KIT & ship, sick, bridge, milk, myth, busy ... \\
\hline e & $\varepsilon$ & 2. & DRESS & step, neck, edge, shelf, friend, ready ... \\
\hline æ & $æ$ & 3. & TRAP & tap, back, badge, scalp, hand, cancel ... \\
\hline $\mathrm{p}$ & a & 4. & LOT & stop, sock, dodge, romp, quality ... \\
\hline$\Lambda$ & $\Lambda$ & 5. & STRUT & cup, suck, budge, pulse, trunk, blood ... \\
\hline U & U & 6. & FOOT & put, bush, full, good, look, wolf ... \\
\hline a: & $æ$ & 7. & BATH & staff, brass, ask, dance, sample, calf ... \\
\hline $\mathrm{p}$ & 0 & 8. & CLOTH & cough, broth, cross, long, Boston ... \\
\hline ว: & ər & 9. & NURSE $^{4}$ & hurt, lurk, burst, jerk, term ... \\
\hline i: & $\mathrm{i}$ & 10. & FLEECE & creep, speak, leave, feel, key, people ... \\
\hline eI & eI & 11. & FACE & tape, cake, raid, veil, steak, day ... \\
\hline a: & a & 12. & PALM & psalm, father, bra, spa, lager ... \\
\hline o: & 0 & 13. & THOUGHT & taught, sauce, hawk, jaw, broad ... \\
\hline$\partial U$ & o & 14. & GOAT & soap, joke, home, know, so, roll ... \\
\hline u: & $\mathrm{u}$ & 15. & GOOSE & loop, shoot, tomb, mute, huge, view ... \\
\hline aI & aI & 16. & PRICE & ripe, write, arrive, high, try, buy ... \\
\hline गI & गI & 17. & CHOICE & adroit, noise, join, toy, royal ... \\
\hline au & au & 18. & MOUTH & out, house, loud, count, crowd, cow ... \\
\hline Іә & $\mathrm{I}(\mathrm{r}$ & 19. & NEAR & beer, sincere, fear, beard, serum ... \\
\hline$\varepsilon ə$ & $\varepsilon(\mathrm{r}$ & 20. & SQUARE & care, fair, pear, where, scarce, vary ... \\
\hline a: & $\mathrm{a}(\mathrm{r}$ & 21. & START & far, sharp, bark, carve, farm, heart ... \\
\hline o: & $\mathrm{o}(\mathrm{r}$ & 22. & NORTH & for, war, short, scorch, born, warm ... \\
\hline o: & $\mathrm{o}(\mathrm{r}$ & 23. & FORCE & four, wore, sport, porch, story ... \\
\hline Uə & $U(\mathrm{r}$ & 24. & CURE & poor, tourist, pure, plural, jury ... \\
\hline
\end{tabular}

${ }^{4}$ Wells's symbols for this set are in fact /3:/ and /3r/. In order to use as few symbols as possible I have substituted /a/ for /3/, as originally used by Daniel Jones and as re-adopted by $A E D$ and by $O E D$ in its latest online revision. 


\section{VOWELS}

\subsection{The KIT set}

The KIT set (Wells, 2.2.1) contains words with a stressed syllable that has the sound /I/ (generally called "short $i$ ") in both RP and GenAm.

7.1.1 In $\$ 16$ of the Diss. Barnes draws a distinction between the vowel sounds in wit and dip in proto-RP, the former being higher than the latter. This may help to explain why words with short $i$ (presumably of the dip type) are sometimes spelled with $e$ and rhymed with words with a stressed syllable that has the sound $/ \varepsilon /$.

7.1.2 Final $-y$ or -ey ("the bappY vowel", as Wells engagingly calls it) is always /i/ rather than /I/.

7.1.3 I have not found any way of predicting which of the two subsets words with short $i$ will belong with, WIT or DIP, and Barnes appears not to distinguish between them in rhyme. Accordingly, though I transcribe final $y$ and $e y$ as $/ \mathrm{i} /$ in accordance with 7.1.2, I use /I/ for all instances of short $i$ that are spelled with $i$, except where other factors (such as the loss of $-\nu$ - in give or -th in with) suggest heightening and/or lengthening of the vowel.

7.1.4 Where spelling and/or rhyme point to an entirely different phoneme in place of short $i$, I transcribe accordingly. For example:

a) bridge and ridge always have the vowel $/ \Lambda /$;

b) pick, rick, hit, spit, if, and a few other words are sometimes spelled with $e$ for $i$, in which case I transcribe the vowel as $/ \varepsilon /$;

c) for grist (rhyming with hoist) see 7.16.11.

7.1.5 In both the broad and the modified forms of the dialect Barnes uses the spelling -in for the unstressed -ing ending on present participles and verbal nouns. There is no apparent difference in pronunciation between this and the unstressed -en ending of amalgamated negatives (e.g. didden), past participles of strong verbs (e.g. given), or other words ending in -en (e.g. maiden, often). Rhymes suggest that the normal pronunciation is /on/, with /In/ and possibly / $\mathrm{en/}$ as an occasional variant. 
7.1.6 I take the word min to mean 'man' or 'mate' or 'friend' and the pronunciation to be $/ \mathrm{mm} /$.

7.1.7 Loss of final /ð/ in with (shown by the frequent spelling wi') leads to raising of / $/$ / to /i/ and possibly lengthening to /ii/ (see 8.13.2).

7.1.8 Loss of /v/ in give (shown by the spelling gi'e) leads to raising and lengthening of / I/ to /i:/ (see 8.15.1).

7.1.9 I take the pronunciation of the stressed syllable in the word spirit to be /sparr/ irrespective of the spelling (spurrit, spirit, or speret), and of that in squirrel (spelled thus or squerrel) to be /skwar/\}.

7.1.10 The pronunciation of women may be /wəmin/ or /wumin/.

\subsection{The DRESS set}

The DRESS set (Wells, 2.2.2) contains words with a stressed syllable that has the vowel generally called "short $e$," /e/ in RP and / $\varepsilon /$ in GenAm. Words with this vowel may have one of three pronunciations in Barnes's poems: $/ \varepsilon /, / \mathrm{I} /$, or $/ \mathrm{a} /$.

7.2.1 The usual pronunciation is $/ \varepsilon /$, as in StE.

7.2.2 /I/ for $/ \varepsilon /$. Some words sometimes have /I/ for $/ \varepsilon /$, but the evidence suggests that $/ \mathrm{I} /$ is only an occasional variant. I therefore transcribe the vowel as $/ \varepsilon /$ except where spelling or rhyme show that Barnes intended the pronunciation with $/ \mathrm{I} /$.

7.2.3 /a/ (see 7.3, TRAP) for $/ \varepsilon /$. Barnes comments that in Dorset " $a$ is frequently substituted for $e$ : as in bag, beg[;] bagger, begger; kag, keg; agg, egg; lag, leg" (Diss., \$18). The substitution is also found in words that do not have the combination -eg: drash (thresh), drashel (threshold), langth (length), alassen (unless), strangth (strength), stratch (stretch), watshod (wetshod), and yaller (yellow: 3 instances only, all in 1844, the more usual spelling being 
yoller, see further 7.4 below). I transcribe the vowel as $/ \varepsilon /$ except where spelling or rhyme show that Barnes intended the pronunciation with $/ \mathrm{a} /$.

\subsection{The TRAP set}

The TRAP set (Wells, 2.2.3) contains words with a stressed syllable that has the vowel generally called "short $a$." It contains all words with /æ/ in RP and those words with $/ \mathfrak{x} /$ in GenAm that do not belong in the BATH set (7.7 below).

7.3.1 "In most rural western speech the TRAP vowel is qualitatively [a] rather than [æ]" (Wells, 4.3.7, p. 345). I have assumed that this is true for Barnes's poems.

7.3.2 There is a small group of words spelled with $a$ in StE showing variation in spelling between $a$ and $o$ in Barnes's poems (gnat, sat, and a few words spelled with $o$ in StE discussed under 7.4), presumably reflecting variation in pronunciation between $/ \mathrm{a} /$ and $/ \mathrm{p} /$. I have assumed an intermediate pronunciation between the two, i.e. /a/.

$\{$ Rottle (always so spelled) may appear to be a form of rattle, like zot for sat. $O E D$ notes, however, that rattle and rottle have different origins, the first "related to Dutch ratelen to chatter, babble, to make a rattling or clacking sound," the second "to Middle Dutch rotelen to rattle, to clatter, to breathe laboriously, to wheeze." We may take it, accordingly, that the vowel in rottle is $/ \mathrm{p} /$, not $/ \mathrm{a} /$. Similarly with yoppèn ('yapping'): EDD records spellings with $o$ and pronunciations with $/ \mathrm{p} /$ in several SW counties, including Dorset.

7.3.3 Spelling and rhyme evidence show that in Barnes's poems the verb carry becomes / karr/, with loss of final / i/ and lengthening of the vowel to /a:/.

7.3.4 On the evidence of the short $a$ in $O E D$ (s.v. clavel) I have assumed that clavy has a short $a$ in Barnes's poems, i.e. /a/.

7.3.5 I have assumed that the vowel in unstressed and, as, at, than, that, etc. is reduced to /o/, as in $\mathrm{RP}$. 
7.3.6 For plait, a member of the TRAP set in RP, see 7.11.6 below.

\subsection{The LOT set}

The LOT set (Wells, 2.2.4) contains words with a stressed syllable that has the vowel generally called "short 0. " This includes words with / $\mathrm{v} /$ in RP (excluding those that belong in the CLOTH set, 7.8 below) and /a/ in GenAm, whether spelled with o (top, pot, dog, clock, copse, etc.) or with a (what, watch, want, wasp, etc.).

In Barnes's poems the vowel is normally $/ \mathrm{p} /$, in spite of the general unrounding in the SW to $/ \mathrm{a} /$. There is a handful of words that show variation in spelling between $a$ and $o$ : drop, John and Johnny, yond (in beyond and yonder), and yellow (yaller or yoller in 1844, always yollow in the modified form of the dialect). As with gnat and sat in 7.3.2 I assume that the vowel is /a/, intermediate between $/ \mathrm{a} /$ and $/ \mathrm{p} /$.

7.4.1 I assume that the vowel in unstressed from and in of when spelled $o$ ' (for which see 8.3.2) is reduced to /o/, as in RP.

\{7.4.2 The hovel / shovel rhyme in "Eclogue: The 'lotments" may strike RP speakers as a half-rhyme, but, since $O E D$ gives $/ \mathrm{h} \Lambda \mathrm{v} /$ as an alternative to / hpv/ for the stressed syllable, we may take it as a full rhyme on the sound $/ \Lambda \mathrm{val} /$.

\subsection{The STRUT set}

The STRUT set (Wells, 2.2.5) contains words with a stressed syllable that has the vowel $/ \Lambda /$, generally called "short $u$," in both RP and GenAm.

7.5.1 There was no distinction in ME between the vowel sound in cut and that in put: both had the sound / $/$, as they still do in the north of England. In Barnes's poems, as in RP and the south of England generally, the sound is normally $/ \Lambda /$. 
7.5.2 A few words in Barnes's poems have $/ \Lambda /$ where they do not have it in RP: put, pudding, roof (usually spelled ruf), bosom (frequently burzom in 1844), self (frequently spelled zuf, especially in myzuf, etc.). (I have assumed that the stressed syllables in butcher and hovel (for which see 7.4.2) likewsise have $/ \Lambda /\}$. Occasional rhymes between words with $/ \Lambda /$ and words from Wells's GOAT set suggest that the second element of that diphthong would have been $/ \Lambda /$ or $/$ o/ (see further 7.14.3).

7.5.3 Love and the stressed syllable of above have / $\Lambda /$, as in RP; but it is not clear whether rhymes between one of these and other words ending in -ove (move, prove, grove, drove, rove) are true rhymes or simply eye-rhymes. Jennings's rhymes and spellings—appruv, appruv'd (rh. lov'd), pruv (outside rhyme as well as rh. love), pruf (proof), ruf (roof), rum (room), shut (shoot, rh. put)-suggest that in the early 19th century some words with /u:/ in RP (prove approve, proof, roof, room, shoot) had $/ \Lambda /$ in East Somerset, thus supporting Barnes's rhyming not only of move / prove / love / above but also of roof / buff / stuff / enough. It seems reasonable therefore to transcribe move, prove, and roof with $/ \Lambda /$ in Barnes's poems \{although the two occurrences in 1844 of the spelling môv(in "The milk-mâid o' the farm" and "Looks a-know'd avore") may suggest /mo:v/ as an alternative for move $\}$; but drove, grove and rove remain problematic.

7.5.4 The words rut, strut, and a-strut are always spelled with -out in Barnes's poems and are rhymed only with the word out. It is clear that their vowel is the / oru/ diphthong of the MOUTH set (see 7.18.1, 7.18.4).

7.5.5 That crust and dust sometimes have $/ \Lambda /$ as in RP is shown by rhyme, but Barnes's preferred spelling for both words outside rhyme is with -oust, suggesting that his preferred pronunciation for these words, too, is with the diphthong / əu/ (see again 7.18.1, 7.18.4).

7.5.6 In its sole occurrence in rhyme (with dust) just is spelled (and evidently pronounced) as in StE, /d $3 \wedge$ st/. But Barnes's normal spellings in 1844 are jis' and jist, suggesting that his preferred pronunciations are /dzis/ and /dzIst/. \{Similarly such is always spelled sich in 1844 (apart from two occurrences of such in "Ānt's tantrums"); and in "Bees a-zwarmen" it is 
rhymed with ditch and pitch, showing that the preferred pronunciation was /sits/. In later editions, however, such is also frequently used, suggesting that /s st S/ was an acceptable alternative.\}

7.5.7 Spelling and rhyme suggest three possible pronunciations for one (and for the pre-final element of once) in Barnes's poems: /u:n/, /wu:n/, and (as in RP) /wan/. The word arn, which occurs only in "The witch" in 1844 and 1847 , is not another form of one, but a contraction of the phrase ever a one.

7.5.8 Although none is descended from the same OE root as one, its spelling (nuone in 1844, nwone in the modified form of the dialect) and its use in rhyme suggest different development in the dialect, the likely pronunciation being /nu n/ or /nuən/. As with arn (see 7.5.7) so with narn: it is a contraction of never a one (not entered in the 1844 Glossary), pronounced /na:rn/.

7.5.9 For among (RP/om^y/) see 7.8.3.

7.5.10 I have assumed that words such as but, must, up, us, etc. have unstressed forms with $/ \mathrm{\partial} /$ for $/ \Lambda /$, as in RP.

\subsection{The FOOT set}

The FOOT set (Wells, 2.2.6) contains words with a stressed syllable that has the vowel / $/$ in both RP and GenAm. Most words belonging to this set can be expected to have / $\mathrm{U} /$ in Barnes's poems, just as in RP. The following additional points should be noted:

7.6.1 Some words that have / / in RP have / $\Lambda$ in Barnes's poems, e.g. put and bosom (see 7.5.2); there is, however, no evidence to suggest that push and bush do not have / $/$ as in RP.

7.6.2 Some words with /u:/ in RP have / $/$ in Barnes's poems, e.g. food, mood, and moot ('tree-stump'). \{The rhyme mood / a-woo'd in the refrain of "Meäry wedded" suggests, however, that RP /mu:d/ is an acceptable alternative for mood.\} 
7.6.3 Some words with /u:/ in RP may have either / $/$ or /u:/ in Barnes's poems, e.g. shoot, rhyming with foot and soot as well as with flute.

7.6.4 Some words with / $/$ in RP may have either / $/$ or /u: in Barnes's poems, e.g. wool, which rhymes not only with pull but also with pool.

7.6.5 Look is frequently spelled $10^{\prime} k$ in 1844 , but it is rhymed only with brook, nook, and other words having the vowel / $/$, as in RP. In the absence of any firm evidence to the contrary, I transcribe all forms of look as /luk/, irrespective of their spelling. Lauk has no connection with look: it is an exclamation corrupted from Lord (of the same type as gosh from God), and has, I assume, its normal pronunciation, /lo:k/.

\subsection{The BATH set}

The BATH set (Wells, 2.2.7) contains words with a stressed syllable that has the vowel /a:/ in RP and /æ/ in GenAm: staff, brass, ask, aunt, master, dance, sample, calf, etc. Strictly speaking, father belongs with the PALM set (see 7.12 below), but it is dealt with here since it behaves in the same way as after, calf, laugh, last, etc. The pronunciation of words in the BATH set in Barnes's poems is strikingly varied, from $/ \mathrm{a}$ / to $/ \mathrm{ja}$ / to $/ \varepsilon: /$.

7.7.1 The pronunciation of the vowel in the BATH set in Barnes's poems is likely to be /a:/, further forward than RP /a:/.

7.7.2 The rhymes grass/ass, grass/lass, and pa'son/cassen, which would in RP be false rhymes between a long and a short vowel, may well have been true rhymes for Barnes. As Wells points out, "vowel length is not as important phonologically in the west as it is in other parts of England. Traditionally short vowels are lengthened in many environments.... This applies particularly when ... monosyllables are phrase-final and intonationally prominent"- as they would be at the end of a line (4.3.7, p. 345). It seems probable that the short vowel in ass, lass, and cassen ('canst not') was lengthened to /a:/, making these true rhymes.

7.7.3 Barnes's spelling of master in 1844 (always miaster, replaced by meäster in the modified form of the dialect) is a clear indication of an introductory 
$i$-glide, creating the sound $/ \mathrm{ja}$ :/ (with the stress on the second element) for the stressed vowel. (A similar glide is found in garden and part, see the START set, 7.21.2-3 below.)

7.7.4 On some of the words in this and the palm set Barnes himself comments, "The third [front] sound of $a$ in mate is often substituted for the first [back] one of $a$ in rather; as fäther, father; lafe, laugh; àter, after; bäfe, half. The author has in this case marked it $\vec{a}$ " (Diss., $\$ 23$ ). To these examples may be added others from the BATH set with non-StE spelling in 1844, e.g. aunt, answer, can't, dance, glance, last, path, etc. Barnes uses several different spellings to indicate the dialect pronunciation: addition of final $-e$ (as frequently with laste); addition of a length mark over $a$ (as declared in the Diss.); substitution of ae or $\bar{e}$ for $a$ (as sometimes with faether for father and leste for last), etc. Though the spellings vary, however, and though all these words are respelled conventionally in the modified form of the dialect, Barnes is remarkably consistent in showing in 1844 that he did not wish these words to be pronounced as in "book English". To the best of my knowledge, indeed, every instance of one of these words in 1844 is spelled in one of the ways indicating dialect rather than StE pronunciation. In accordance with Barnes's description I transcribe all such words with the sound / $/$ : / (see Section 4 above).

\subsection{The CLOTH set}

The CLOTH set (Wells, 2.2.8) contains those words with short 0 in their stressed syllable that do not belong in the LOT set ( 7.4 above): in RP they have the vowel / $\mathbf{p}$ / (like those in the LOT set); in GenAm they have the vowel / $/$. Words in this set have short $o$ followed by /f/ or /ft/ (off, cough, soft, often, etc.), /s/ or /st/ (cross, toss, frost, lost, etc.), / / (cloth, froth, etc.), /y/ (long, wrong, etc.), or / $\mathrm{r} /$ (quarrel, sorrow, etc.). The pronunciation of words in this set has varied greatly in the SW since the mid 19th century.

7.8.1 Most words in the CLOTH set behave in Barnes's poems in the same way as those in the LOT set $(7.4$ above), retaining $/ \mathrm{v} /$ in spite of the tendency in the SW to unround the vowel to $/ \mathrm{a} /$. 
7.8.2 For quarrel, sorry, and other words with -arr- and -orr- see 7.22.5.

7.8.3 As consistently shown by rhyme, among belongs in this set for Barnes, rhyming always with words in / $\mathrm{py} /$, never (as in RP) with those in / $\mathrm{n} /$.

7.8.4 As shown by both spelling (hoss or ho'se) and rhyme (always with words in -oss), horse belongs in this set for Barnes, pronounced /hps/.

7.8.5 The word soft belongs in this set, with (presumably) the normal pronunciation /spft/. The dialect form sate (occurring only in the 1844 and 1847 versions of "Poll's jack dā" and in Barnes's various Glossaries) has the vowel $/ \varepsilon /$.

\subsection{The NURSE set}

The NURSE set (Wells, 2.2.9) contains words with a stressed syllable that has the sound /o:/ in RP and /or/ in GenAm, spelled with any of several different vowels or vowel combinations followed by $-r$ : -er- (term, herd, etc.), -ear- (earn, heard, etc.), -ir-(fir, bird, etc.), -or- (worth, word, etc.), -our- (scourge, journey, etc.), or -ur- (fur, urn, etc.).

7.9.1 The vowel is pronounced / $\mathrm{a} /$, as in $\mathrm{RP}$, but the following / $\mathrm{r} /$ is also sounded (see 8.8.1), yielding / orr/.

7.9.2 The survival of the /arr/ pronunciation from eMnE is shown in Barnes's poems by the -ar-spellings in 1844 in words spelled with -er- or ear-in StE (certain, earn, earnest, German, herb, learn, serve, search, serpent, and their compounds, spelled sarten, sarta(i)nly, yarnest, jarman, yarb, larn, sar or sarve, sarch, sarpent in 1844, sometimes respelled as in StE in the modified form of the dialect), and by rhymes in which some of these words appear. The rhyme earn / burn in "Eclogue:-The common a-took in" \{supported by that of yearm / vern / burn in "Trees be company", 5-8\} suggests, however, that in his own day Barnes regarded /arr/ in earn as an acceptable alternative to /arr/, in spite of the 1844 spelling yarn. \{Similarly both rhyme and spelling in burt / smert in "Pity", 11-13, suggest /arr/rather than /arr/ in smert 'smart' $(v \cdot)$. 
7.9.3 Words from 7.9.2 with initial er- or ear-are consistently spelled with initial yar in 1844 , clearly indicating a pronunciation with initial $/ \mathrm{j} /$, thus yarn, yarnèn, yarnest, yarbs ('earn, earning, earnest, herbs'); the initial combination is less helpfully respelled in later editions as eär.

7.9.4 Metathesis of $r+$ vowel brings some words into this set in Barnes's dialect that would not otherwise belong here; thus girt and pirty or perty (often standardized to pretty in later editions), both with /a:r/, for great and pretty (Diss., §34; see 8.8.3).

7.9.5 Loss of /r/ before "a hissing palate letter" $(/ \mathrm{s} /, / \mathrm{z} /, / \theta /)$ takes some words out of this set in Barnes's poems that would otherwise be in it (see Diss., $₫ 35$, and 8.8 .5 below):
a) /o:rs/ becomes / $\varepsilon \mathrm{s} /$ in verse (spelled vess or ve'se);
b) /o:rs/ becomes / u:s/ in worse (spelled woose or woo'se);
c) /o:rst/ becomes / $/ \Lambda \mathrm{st} /$ in burst, first, nursed, worst (spelled bust, vust or vus't, nuss'd, wust);
d) / $\mathrm{a}: \mathrm{r} \theta /$ beomes $/ \varepsilon \theta /$ in earth, birth, mirth (spelled eth, beth, meth or e'th, be'th, me'th);
e) /a:r $\theta /$ beomes $/ \mathrm{p} \theta /($ or $/ \Lambda \theta /$ ) in worth (usually spelled woth or wo'th, though entered as wuth in the expanded Glossary of 1847);
f) /o:rz/ becomes $/ \Lambda z /$ in furze (spelled vurz).

7.9.6 The vowel in heard may be /arr/ as in StE (or /jarr/, with the stress on the second element, when heard is spelled heärd), or /irr/ (with the stress on the first element), as shown by rhymes with beard, feared, and sheared.

7.9.7 As shown by spelling (murn) and confirmed by rhyme, mourn is a member of the NURSE set for Barnes (with the pronunciation /mə:rn/), though it belongs with the FORCE set in StE (see 7.23.5).

\subsection{The FLEECE set}

The FLEECE set (Wells, 2.2.10) contains words with a stressed syllable that has the vowel "long $e$," pronounced /i:/ in RP and /i/ in GenAm. The 
native English words are generally spelled with ee like fleece itself (feet, seed, keen, etc.), with ea (heat, bead, mean, etc.), with $e+C+e$ (even, etc.), with ie (field, etc.), with $e y$ (key), or with $e$ alone (be, me, etc.); the words adopted from other languages (only the commonest of which are used in Barnes's dialect poems) may be spelled in any of these ways, or with ei (conceit, receive, etc.), with $i+C+e$ (machine, police, etc.), or with various other combinations, such as eo (people), oe (phoenix), ay (quay), ae (Caesar), etc. Words with this sound in current English that occur in Barnes's poems may have any of the several possible pronunciations discussed below.

7.10.1 The majority of words spelled with $e e, e+C+e, i e$, or $e$ alone and pronounced /i: in RP (descended from /e:/ in ME)—deep, see, evening, field, me, etc.- have /i:/ in Barnes's poems as in RP. But been is always spelled bin or ben in 1844, though frequently StE been is substituted in later editions. I take it that the possible pronunciations are /bin/, /bin/, or /bi:n/. The pronoun be will normally be /hi:/, but the unstressed form, 'e, is /a/ (Diss. \19). One may reasonably posit also a semi-stressed form in /ii/ or $/ \mathrm{i} /$.

7.10.2 Barnes consistently spells chime and shine with ee (see Diss., \$23), and the pronunciation with / $\mathrm{i} /$ is confirmed by rhyme.

7.10.3 Most words that had / $\varepsilon$ : in ME (generally now spelled with ea) have developed /ii/ in RP, so that meat, sea, and bean have become homophones of meet, see, and been. Where Barnes gives no indication to the contrary, whether in spelling, rhyme, or grammatical commentary, it is reasonable to assume that the pronunciation is /i:/; but some words spelled with ea and pronounced with /i:/ in RP are pronounced in other ways in Barnes's poems; a number of them appear to fluctuate between /i:/ and an alternative pronunciation, as discussed below.

7.10.4 As Barnes himself remarks in $\$ 19$ of the Diss., "For the first long close sound of ea as in beaver, dream, the second is often substituted, as bever, drom...." That is to say, in Barnes's dialect the highest long front vowel, /i:/, is often replaced by the vowel immediately below it, which he describes in $\$ 16$ of the Diss. as "e long in the western dialects" and which he calls elsewhere "the Dorset e"” (1863 Grammar, p. 11) or "the Dorset ê" (1886 
Glossary, p. 1). The sound intended appears to be /e:/ (often indicated by the spelling $\bar{e} a$ or $\bar{e}$ ), but Barnes's practice in both spelling and rhyme suggests that pronunciations with / $\mathrm{i} /$ and /e:/ were both acceptable in his dialect. Accordingly I transcribe the vowel in words spelled with ea in StE as /e:/ when Barnes spells it with $\bar{e} a$ or $\bar{e}$, but otherwise as /i:/. \{Where, however, words with éa are rhymed with words having ea or ee, as in plèase / vleas in "Bob the fiddler" and éase / trees in "Evemèn in the village" (both in 1844), I transcribe both words with/i:/. But ease is also spelled yease in "The Church an' happy Zunday" (1844), indicating initial / $\mathrm{j} /$; and several times in 1879 it's spelled eäse, and rhymed with words that have the sound /ia/. There appear to be several possible pronunciations for ease: /i:z/, /e:z/, and /iəz/, with or without initial $/ \mathrm{j} /$ in each case.\}

7.10.5 The spelling $\bar{e}$ appears in 1844 not only in words spelled with ea in StE but also in a small number of other words with $/ \mathrm{i}$ / or $/ \varepsilon /:$ bèn't (be not, i.e. 'are not'); crēp (creep); mèsh(y), mashy (moss, mossy, from OE meos, see OED tmese, $\left.n^{1}{ }^{1}\right) ; n \bar{s} h$ (nesh, i.e. 'soft, tender'). In all these instances the vowel is presumably /e:/.

7.10.6 The verb drive is almost always spelled drève in 1844 and 1847 (thereafter usually dreve), indicating that it has /e:/.

7.10.7 Other commentators also note the preference for /e:/ over /i:/ in SW dialects in many words that have /i:/ in StE.

7.10.8 A handful of words in 1844 are spelled with eä: afeärd, beäns, beänhan' (bear in hand, i.e. 'think, believe'), beäs (beasts), beät, bleät, cheäk(s), cleän, deäl, feäst, geät(e) (gate), heärd, Jeän, leäd, leän, leäp, leäse or leäzre (a stocked pasture "in distinction from a mead which is mowed," 1844 Glossary), leäst, leäve, leäzer (gleaner), meäd(s), meän(èn), and sheärs. I transcribe this sound throughout as /ia/. (On the similarity between this diphthong and that in words belonging to the FACE set see 7.11.2; on the instability of the diphthong in beat and mead see 7.11.3.)

7.10.9 The rhyme with leäze in the second stanza of "Sweet music in the wind" ('I'll think how in the rushy leäze / O' zunny evemens jis' lik' theös, / 
In happy times I us'd to zee / Thy comely shiape about thik tree" shows that the vowel of the demonstratives theös (1844) and theäse (later editions), both meaning this or these, has the same sound as that discussed in the preceding paragraph, /iə/.

7.10.10 Barnes invariably spells heat in his dialect poems as het and rhymes it with words ending in /et/; the vowel is thus clearly not the /i:/ of StE but $/ \varepsilon /$.

7.10.11 Keep, meet, and week may be spelled with either ee or $i$ in 1844 . Although keep is rhymed only on the sound /i:p/ and meet on /itt/, week is rhymed on both /i:k/ and / $\mathrm{ik} /$. The rhymes on / $\mathrm{rk} /$ are kept in later editions, even when week is respelled as in StE. The logical conclusion is that in these words pronunciations with /i:/ and / I/ were both acceptable in Barnes's dialect. In transcribing these words, accordingly, I use $/ \mathrm{i}(\mathrm{:}) /$ when the spelling is with $e e$, and /I/ when it is with $i$.

\{Seem is usually so spelled, and rhymes with team, cheem, scream, dream, etc.; but it is also occasionally spelled sim. I transcribe it accordingly as /sim/ when it rhymes on the sound /i:m/, / $\mathrm{si}(\mathrm{i}) \mathrm{m} /$ when the spelling is seem outside rhyme, and / sim/ when the spelling is sim. Similarly sweet, spelled with $i$ in swithearts in the second stanza of "The woody holler" (1844), but elsewhere always with ee, and rhymed with meet, veet, and sheet.\}

7.10.12 The current pronunciation of key, sea, and tea in StE makes them members of the FLEECE set; historically, however, they belong with the FACE set. They are discussed in 7.11.7 and 7.11.9 below.

7.10.13 In Barnes's dialect poems cheek is never spelled with ee as in StE but almost always with $e \ddot{a}$, suggesting that the dialect form is derived from the West Saxon céace, in contrast to the StE form, which is from Anglian céce. Barnes's consistent avoidance of the spelling cheek confirms that vowel is never /i:/; his favoured spelling, with $e \ddot{a}$, implies that the pronunciation will always be /iə/ (see 7.10.8 above).

7.10.14 The usual spelling of weak and its derivatives in Barnes's poems is with $e a$, as in StE; occasionally with $\bar{e} a$ or $e \ddot{a}$. Nowhere, in spite of its usual 
StE spelling, does weak rhyme with a word that has, indisputably, the vowel /i:/ as in RP. Since /i:/ cannot be conclusively ruled out, however, the possible pronunciations appear to be /we:k/, with the Dorset $\bar{e}$ (see 7.10.4), /wiək/, as in the rhymes with cheäk, and /wi:k/, as in RP.

7.10.15 The word peony appears rarely in Barnes's dialect poems: once, spelled piny, once, in the plural, spelled pinies in both early and late editions. In present-day recordings it is rendered variously as /parni/, /pini/, and /pini/, all of which would appear possible from the 18th-century spellings piney, piny, pinny, and peeny recorded in OED for the south of England. Barnes's spelling perhaps (but not certainly) implies /pə:Ini/ (see 7.16.1).

\subsection{The FACE set}

The FACE set (Wells, 2.2.11) contains words with a stressed syllable that has the vowel "long $a$," the diphthong /er/, in both RP and GenAm. This may be spelled in a number of different ways $(a+C+e, a i, a y, e i$, ey, eigh, etc.), representing several different origins; these different origins tend to have different pronunciations in Barnes's dialect, as shown below.

7.11.1 The commonest spelling for this set in $\mathrm{StE}$ is $C+a+C+e$, as in bake, case, shape, etc. Barnes's normal spelling for the $a$ in this combination in 1844 and 1847 is ia (biake, ciase, sbiape, etc.); in later editions the ia is replaced throughout by eä (beäke, ceäse, sheäpe, etc.). As explained in 7.11.2, I transcribe this sound as $/ \mathrm{j} \varepsilon /$.

7.11.2 The similarity between the diphthongs in words spelled with $i a$ and $e \ddot{a}$ in 1844 calls for further comment. Not only is Barnes's initial description of the diphthongs (in $\int \mathbb{S 1 9}$ and 21 of the Diss.) the same, but his decision to spell them in the same way (with $e \ddot{a}$ ) in later editions suggests perhaps that the difference in pronunciation is too slight to be worth bothering about. If this is indeed the case, it makes homophones or very near homophones of such pairs as bane (1844 biane, later editions beäne) and bean (always beän), lane (1844 liane, later editions leäne) and lean (always leän). Nevertheless, with the exception of beat, gate, and mead, which appear to be special cases (see 7.11.3), Barnes avoids rhymes between words of the bane type and those of 
the bean type. It is clear, then, that the distinction between the two diphthongs was important to Barnes.

This distinction involves not only the quality of the second element of the diphthong $(/ \varepsilon /$ in the one case, $/ \partial /$ in the other) but also the placement of stress. In words of the bean type, where the second element is $/ \partial /$, the stress will be on the first element, since the second element, schwa, is by its very nature unstressed. Thus beän, with a falling diphthong, will sound similar to StE bean, but with a slight off-glide following the initial $/ \mathrm{i}(\mathrm{i}) /$; in ordinary script its sound might be represented as "BEEun." In bane and other words from the face set, in contrast, there is evidently a rising diphthong (with the stress on the second element), as shown by the rhymes with words such as let, wet, neck, etc.; in ordinary script the sound of bane might be represented as "biEN" or "byEN." (To distinguish between these falling and rising diphthongs in this guide I use / $\mathrm{i} /$ as the first element of a falling diphthong and $/ \mathrm{j} /$ for the first element of a rising diphthong, hence the transcriptions / bion/ for bean and /bjen/ for bane.)

7.11.3 The words beat, gate, and mead appear to be special cases where the diphthong is sufficiently unstable to allow rhymes with words from different sets. Beat, always spelled beät, will normally be expected to have the diphthong /iə/ (see 7.10.8); it is rhymed, however, only with gate (several times) and wet, the second rhyme clearly suggesting that the diphthong is $/ \mathrm{j} \varepsilon /$. Gate (spelled giate, ghiate, geät, or geäte) rhymes not only with let and wet, but also with beat and treat. The rhymes with let and wet are to be expected, assuming that the diphthong in gate is normally / je/; that with treat, however, suggests that the diphthong is /ia/. As for the rhymes between gate and beat themselves, it would appear that the diphthong in both words may be either /iə/ or /je/. Mead, always spelled meäd, shows more flexibility than beät: it rhymes not only with lead, snead, and bead (all with the diphthong /iə/) but also with zeed and reed $(/ \mathrm{i}$ : $/)$, homestead $(/ \varepsilon /)$, and shade $(/ \mathrm{j} \varepsilon /)$, suggesting three possible pronunciations for mead: / $\mathrm{mird} /, / \mathrm{mi}: \mathrm{d} /$, and $/ \mathrm{mj} \varepsilon \mathrm{d} /$.

7.11.4 The rhyming of again (spelled agen, ageän, agiën, or agaen) with words ending in both -en and -ane may suggest that again has the same two 
pronunciations in the dialect as in StE, /ogen/ and /ogern/. But the rhymes with words in -ane are on /jen/ (see 7.11.1-2); again is not rhymed with words ending in -ain, which would have the sound /ærn/. The possible pronunciations of again in Barnes's dialect are /ogen/ and /ogjen/ (the same rhyme sound, with or without an introductory $i$-glide).

7.11.5 When the vowel is in initial position, as in able, acbe, acorn, acre, ale, ape, apron, the spelling of 1844 is invariably ya- (yable, yache, etc.), suggesting that in initial position the introductory $/ \mathrm{j} /$ has some prominence; the spelling is changed in later editions to eä (eäble, eäche, etc.). Barnes's two spellings of acorns in 1844 (yacors and yakkers, both replaced by eäcorns in later editions), suggest two possible pronunciations, /jekərz/ and /jakərz/.

7.11.6 One group belonging to the FACE set contains words spelled with $a i$, $a y, e i, e y$, or eigh (excluding those words with ay or ey discussed in 7.11.7, 8, and 10). Barnes's own comment on this group in $\$ 22$ of the Diss. is as follows: "The diphthongs ai or ay and $e i$ or $e y$, the third long [front] sound as in May, hay, maid, paid, vein, neighbour, prey, are sounded,--like the Greek [i.e. Classical Greek] $a i$, — the $a$ or $e$ the first [back] sound as $a$ in father and the $i$ or $y$ as $e e$ the first [front] sound. The author has marked the $a$ of diphthongs so sounded with a circumflex; as Mây, hây, mâid, pâid, vâin, nâighbour, prây." In later editions $a \ddot{i}$ and $a \ddot{y}$ are substituted for $\hat{a} i$ and $\hat{a} y$ (Mä̈, bäj, maïd, païd, vaïn, naïgbbour, etc.). Barnes's description of the diphthong as a combination of /a:/+/i:/ (or, with short vowels, /a/+/i/ = /ai/) makes it sound very similar to the /aI/ diphthong of RP high, pride, cry, etc. In current recordings of Barnes's poems read by conservative dialect speakers, however, the diphthong sounds closer to the /æI/ of Cockney mate or Australian G'day. I transcribe the diphthong in this group, accordingly, as /æI/.

The inclusion of plait in this subset, as implied by the spelling plaited (/plæitrd/) in the third stanza of "Pentridge by the river," may be surprising to RP speakers, for whom the word belongs in the TRAP set; but Barnes's listing of the word in the 1854 Philological Grammar as an example of the "third long sound" in proto-RP, along with main, rain, strait, etc. is supported by the detailed etymological note in $O E D$, showing that the current pronunciation is recent. 
The pronunciation of aye in Barnes's poems is uncertain. OED distinguishes between aye 'ever' (RP/eI/ or / $\mathrm{\Lambda I} /$ ), from $\mathrm{ON} e i$, ey, and aye 'yes' (RP / $\mathrm{\Lambda I} /$ as in I, eye, etc.), of unknown origin. The rhyme of aye 'ever' with away in "The geäte a-vallén to" suggests /e:/ or /æI/ in Barnes’s dialect for the former (see 7.11.8); that of aye 'yes' with paÿ in line 21 of "Bleäke's house in Blackmwore" suggests /æI/ as in the first paragraph of this entry for the latter. I transcribe both words as $/ æ I /$.

7.11.7 A second group containing words spelled in StE with ay or ey (and their derivatives) forms a subset of its own. Its members are clay, day, fay ( $v$. 'succeed, prosper'), lay, say, way (but see further 7.11.8), grey, key, and whey, in all of which the ay or $e y$ is descended from OE $a g$ or $e g$, with the vowel long or short. (The final $g$ in these words in OE was pronounced not $/ \mathrm{g} /$ as in $d o g$ but $/ \mathrm{j} /$ or $/ \mathrm{i} /$ as in present English day.) Barnes's spellings for these words, in addition to the StE spelling, include $a, \bar{a}, a e, \bar{a} e, a$, and $\bar{e}(c l \bar{a}$; $d a$, da dae, dàe; làe, lae; ₹ā, zae; gré (in grègole 'bluebell', later respelled gragle); and whè; for way see 7.11.8); except in vary rare instances they are not spelled with ây (1844) or aij (later editions) and do not rhyme with words so spelled, discussed in 7.11.6. Barnes notes that day and whey have the Dorset $\bar{e}$ (1886 Glossary, p. 3), and I normally therefore transcribe the vowel in this group of words as /e:/ (see 7.10.4 above); day and fay, however, are exceptional in that they are rhymed both with words in this group and with words in 7.11.6, suggesting the co-existence in the dialect of the pronunciations /de:/, /fe:/ and /dæI/, /fæI/.

Whereas laid and said (OE lagde and sagde), the past tenses of lay and say, are the same in form (apart from the initial consonant), their pronunciation in RP has diverged, laid retaining the vowel of the infinitive and said normally being shortened to /sed/. Rhymes show that in Barnes's dialect this divergence has not happened: said (spelled zed, zaid, or zaïd) is pronounced as in RP and laid (though spelled as in StE) has evidently undergone the same shortening, since it rhymes only with words ending in $/ \varepsilon d /$.

The current pronunciation of key in StE, with / $\mathrm{i} /$, makes its presence in this group seem odd, but this pronunciation is, as OED points out, 
"abnormal"; and "that key had the same vowel [as clay, grey, etc.] in ME. is proved not only by the frequent spelling kay, but by its constantly riming with day, way, say, play, etc. This was evidently the standard pron[unciation] down to the close of the 17 th c.; Dryden has the rime with way more than once in one of his latest works (1700)" (OED, key, $\left.n .{ }^{1}\right)$. See further 7.11.9.

7.11.8 The pronunciation of way and away is very unstable. Historically these words belong with the subset in 7.11.7, and where they are spelled with ay without diacritics (as is usually the case) and/or where they are rhymed with a word from the clay subset, my assumption is that that their vowel is the Dorset $\bar{e}, / \mathrm{e}$ /. But they are occasionally spelled with äj in later editions and frequently rhymed with words from the May, hay subset in 7.11.6, showing that, like day and fay, they have an alternative pronunciation with /æI/. They are also sometimes spelled with oy, both outside rhyme (particularly in 1844) and in rhymes with boy, showing the coexistence of a third pronunciation with /oiI/ (see further 7.17.1, 7.17.4). We thus have three pronunciations for the vowel of way and away in Barnes's poems: /e:/, /æI/, and / əI/.

Always, though derived directly from way, appears to behave differently, doubtless because the major stress is normally on the first syllable. To the best of my knowledge it is never spelled with $\hat{a} y$, ayj, or $y$, and does not occur in rhyme. In the absence of deviation from the StE spelling always and of rhymes suggesting otherwise, I take it that the vowel in the second syllable is normally /e:/. But heavy stress on the first syllable may lead to some reduction of the vowel in the second syllable, as suggested by the spelling alwiz in line 8 of the 1844 version of "The milk-mâid o' the farm". Here the vowel in the second syllable may be /I/, as implied by the spelling; alternatively it may be further reduced to $/ \mathrm{\partial}$.

7.11.9 Sea and tea (though their vowels are not from the same source) might be considered honorary members of the group in 7.11.7. Barnes's rhymes indicate clearly enough that the usual Blackmore Vale pronunciation of tea was /te: / it is reasonable to assume that the rhyme tea/key would have been on the sound /e:/, since key rhymes elsewhere only with day and grey, and tea only with lay); they show also that pronunciations of sea as /se:/ and as /si:/ 
were both current in his dialect (as they were in StE for Cowper, Dryden and others), allowing rhymes on either vowel.

7.11.10 The word they has many different spellings in 1844: tha, tha', they, they, tha $\bar{a}$, thae, thäe (rare), the (rare), and the (rare); in later editions the only spelling is they. The spellings other than tha and tha', and the sole instance in which they appears as a rhyme word, rhyming with day in "The girt wold house o' mossy stuone" (in 1844 and 1847 only), all point towards the Dorset $\bar{e}$ (see 7.10.4 and 7.11.7 above). It is possible that tha and tha' represent an unstressed form, /ðə/ (cf. ya and da for you and do, 7.15.5); but the occasional occurrence of tha as a demonstrative pronoun in positions where it would be expected to carry some stress makes this unlikely. I therefore transcribe all forms of they as /ðe:/.

7.11.11 Three words with ea spellings that belong in the FACE set in StE are break, steak, and great. Barnes's rhymes suggest that break (occasionally spelled bréak or brè $k$ in 1844) has two possible pronunciations in the dialect, one with /e:/, the Dorset $\bar{e}$ (see 7.10.4 above), the other with /je/, like words with -ake (see 7.11 .1 above). The spelling steäk in the 1847 version of "Liady-day ..." implies /stiək/ (see 7.10.8), but the 1879 re-spelling, steäke, implies /stjek/ (see 7.11.1-2). Great becomes by metathesis girt (/gə:rt/, see 7.9.4 above).

7.11.12 Words derived from French containing the sequence $a+$ nasal consonant (angel, chamber, change, danger, strange, and stranger) form a separate subset. In 1844 Barnes spells these words consistently with $a+$ double consonant: anngel, chammer, channge, dannger, strannge(r); these spellings are replaced by the StE spellings in 1879 with the exception of chammer, which is retained in the word's sole occurrence, in the penultimate stanza of "Polly be-èn upzides wi' Tom". I transcribe all words in this subset (except Grange) with /a/, thus /andzəl/, /t famər/, etc.

Grange, which appears once only, in "Easter time [b]" (1844) (= "Easter Monday," 1879), is spelled as in StE even in 1844, both spelling and pronunciation being perhaps influenced by its status as a proper name. Its pronunciation is therefore presumably /gre:nd3/ (see next paragraph). 
7.11.13 Words derived from French containing age pronounced / eId3/ in RP (age, cage, rage, stage) form another subset. Since these words always have their StE spelling in Barnes's poems (never the $i a$ or eä forms discussed in 7.11.1), I take it that the vowel is the undiphthongized third long front vowel in Barnes's table of the pure vowel sounds in "national English", as set out in $\$ 16$ of the Diss. I transcribe the vowel in these words, accordingly, as / $\varepsilon: /$.

7.11.14 In the surrounding districts, as in the Blackmore Vale, there is much variation in the pronunciation of long $a$.

\subsection{The PALM set}

The PALM set (Wells, 2.2.12) contains words with a stressed syllable that has the vowel /a:/ in RP and /a/ in GenAm, excluding those where / r/ follows the vowel (for which see the START set, 7.21 below). PALM words "belong phonetically with START (and BATH) in RP, but with LOT in GenAm" (Wells, 2.2.12, p. 143). Most words in this set are recent borrowings from foreign languages, and do not occur in Barnes's poems; of the native English words (and exclamations) listed by Wells, the only ones that occur in Barnes's poems are palm itself, calm, father, hah, and burrah.

7.12.1 There is no reason to suppose that the stressed vowel in palm, calm, hah, and hurrah does not have the same pronunciation in Barnes's poems as that of the majority of words in the BATH set, i.e. /a:/ (see 7.7.1).

7.12.2 For a discussion of the stressed vowel in father see 7.7.4.

\subsection{The THOUght set}

The THOUGHT set (Wells, 2.2.13) contains words with a stressed syllable that has the vowel /o: in RP and / / or /a/ in GenAm, excluding those that belong with NORTH (7.22), or FORCE (7.23), or CLOTH (7.8). The StE spellings of words in this set include anght (tanght, canght, daughter, etc.), au $+C$ (cause, haul, baunt, sauce, etc.), aw alone and aw $+C$ (draw, law, saw, crawl, etc.), all and al (all, fall, appal, etc.), alk (chalk, talk, walk, etc.), al $+C$ and aul $+C$ (salt, false, fault, etc., also pronounced / $/ \mathrm{p}$ in RP, and bald), ought (ought, bought, fought, etc.), and assorted other words (broad, abroad, water). 
Of this set of words Barnes says, "The second long [back] sound, as of $a$ in fall and of aw in jaw, is sometimes turned into the third [front] one $\bar{a}$, as $v \bar{a} l$, in some parts val, fall; $j \bar{a}$, jaw; strā, straw: though brought becomes brote, and fought becomes diphthongal, foüght, of the third and fourth [back] sounds" (Diss., \$24; see also 1863 Grammar, p. 13; 1886 Glossary, p. 4). Where there are no indications to the contrary, we may assume that the vowel in this set is / $\mathrm{a} /$ as in RP. The several possible variations are discussed below, in subsets according to the StE spelling of the words in each subset.

7.13.1 Words with the sound / o:l/ in RP (all, fall, small, haul, crawl, etc.). Whereas these words all have their current spelling in later editions, Barnes rarely uses it for them in 1844 . There his usual practice is to reduce final $-l l$ to $-l(a l, v a l$, smal, etc.) and to omit $u$ and $w$ (hal, spra'l, etc.); occasionally he uses the spelling âl (as in squal / crâl in the 1844 version of "Hây-miakèn"); sometimes he indicates the alternative pronunciation with $\bar{a}$ noted in 7.13 above. I take the $\bar{a}$ spelling to denote / $\varepsilon$ :/ as in fäther, etc. (see 7.7.4); but what is meant by the reduction of $-l l$ to $-l$, the omission of $u$ or $w$, and the occasional use of the spelling $\hat{a l}$, on which Barnes makes no comment other than that fall is "in some parts val"? Assuming that the pronunciation in proto-RP was /o:l/, the likelihood must be that Barnes's spellings with al, a'l, and $\hat{a} l$ indicate the unrounded pronunciation /a:l/. Accordingly I transcribe the sound in this group as / o:l/ where Barnes uses the StE spelling in 1844, as /a:l/ where the spelling is al or a'l (as normally in 1844), and as / $\varepsilon: 1 /$ where this pronunciation is suggested by the spelling with $\bar{a}$ or by rhyme. Almost is normally spelled a'most in both early and late editions; I take the $a$ ' to represent a reduction from /a:l/ to /a:/, the whole word being pronounced /a:mo:st/ when there is some stress on the second syllable, /a:most/ when there is none.

7.13.2 The subset containing words with alk behaves in much the same way as the previous subset, showing the same three possible pronunciations for the vowel. In 1844 words in this subset are almost always spelled with $\bar{a}^{\prime} k$, $\bar{a}^{\prime} k e$, or $a^{\prime} k e$, implying / $\varepsilon: \mathrm{k} /$, but occasionally with $a^{\prime} k$, implying /a:k/, or 
auk, implying / o:k/. Words in this subset rhyme only with other words from the same subset.

7.13.3 The subset containing words with $a u(+C)$ or $a w(+C)$ shows similar variability. The preferred spellings of haunt, saunter, mawn ('basket'), -daw, draw, jaw, law, saw(-pit), and straw in 1844 ( $\bar{a}, \bar{a} e, a e)$ imply the pronunciation $/ \varepsilon:$, with the variants $d r a$ and $l a$ ' in draw and law suggesting the alternative /a:/. Barnes's contribution to EEP has proto-RP /o:/ in law but /e:/ in straw and jaw; on the other hand his spelling of sauce as sass in 1844 (alone and in the derivatives saucepan and saucy) implies /a:/, as does the rhyme sass/pass. \{I take dake (in "The witch," 1844) to be variant of dawk (see EDD dake, v. and dawk, $v^{1}$.) and accordingly transcribe it as $\left./ \mathrm{d} \varepsilon: \mathrm{k} /.\right\}$

7.13.4 Barnes's spelling of because in 1844 (always bekiaze or bekiase, never the $\mathrm{StE}$ because that is used invariably in later editions) shows both that there is an $i$ - or $y$-glide following the velar $/ \mathrm{k} /$ (see 7.21.2), and that the vowel in -cause is the / $\varepsilon$ : / sound of $a+C+e$ (see 7.11.1). My transcription is thus always /bikje:z/.

7.13.5 The spelling anght does not occur in the poems of 1844, though in later editions it is found in daughter, caught (cf. 1844 catch'd), taught, and naught (besides laughter and draught, which belong in the BATH set, 7.7). The sole occurrence of -aught in rhyme that I know of (a-tanght / thought in "Daniel Dwithen, the wise chap") shows Barnes making use in his third dialect collection of StE / o:t/. In daughter, however, Barnes's spellings in 1844, daeter, dāter, and dàtter (the last retained in most instances in later editions of the first collection, but elsewhere replaced by danghter), together with the rhymes in "The farmer's woldest daeter", show that his normal pronunciation in the dialect of the Blackmore Vale was /de:tər/, with / $\varepsilon$ : as the vowel of the stressed syllable (see 7.7.4).

7.13.6 Present-day readers may assume that water will follow daughter in having / $\varepsilon$ : in Barnes's poems, since the stressed vowel in both words is the same in StE. But their vowels have different origins in OE; they have reached RP / o: / by different routes; and Barnes's practice shows that the vowels were pronounced differently in the Blackmore Vale. He invariably 
uses the StE spelling, water, in both 1844 and later editions, and on the sole occasion I know of when water is used in rhyme (as opposed to a nonrhyming refrain) it rhymes with thought her (in “Zummer an' Winter"), showing that the stressed vowel in water is $/ \mathrm{o} /$.

7.13.7 Rhymes with words such as grow'd, know'd, and road, together with the 1844 spellings with -ode (often retained in later editions) show that the vowel in broad and abroad, like that in brought (see next paragraph), is /o:/ as opposed to RP / o:/.

7.13.8 Barnes's comments on brought and fought in $\$ 24$ of the Diss. (quoted at the head of this section) draw attention to anomalies in the subset containing words with ought. An examination of his spellings and rhymes leads to the following observations:

a) ought, nought, sought, thought, and wrought are invariably spelled with ought and rhyme only with words spelled with ought or aught: they are pronounced with / o:t/.

b) brought may be spelled brought (in which form it rhymes frequently with thought): its pronunciation in this case is /brot/. But it may also be spelled brote (the preferred spelling in 1844), or brote, or bro't (in one of which forms it rhymes with throat and smote): in these instances the pronunciation is /bro:t/, in line with Barnes's comment in the Diss. Similarly bought rhymes only with ought and thought, but outside rhyme (in 1844) it is also spelled bote or bo'te: like brought, therefore, it may be pronounced with either / o:t/ or / o:t/.

c) fought is spelled foüght or fönght; it rhymes only with words in -out, bearing out Barnes's comment that it becomes diphthongal. The diphthong is not, however, RP / av/ but Blackmore Vale /arv/ (see 7.18.1, 7.18.3).

d) flought is found only in "Riddles". It does not appear with this spelling in the 1863,1879 , or 1886 Glossaries, or in OED or EDD. It is perhaps to be identified with "Flout, a flinging, or a blow of one" (1879 Glossary), which would make sense in the context, in which Anne's cow "het the paill a flought, / An' flung [her] meal o' milk half out"; alternatively a flought may perhaps be a late survival of 
the predicative adjective aflocht 'in a flutter, agitated,' which would make equally good sense in the context (although the three occurrences in $O E D$ are all Scottish and all date from the 16th century). Whatever the meaning of the word, however, the rhyme with out shows that it is pronounced with the diphthong / a:v/ (see 7.18.1, and cf. fought, above and 7.18.3).

\subsection{The GOAT set}

The GOAT set (Wells, 2.2.14) contains words with a stressed syllable that has the vowel /ov/ in RP and /o/ or /ov/ in GenAm, traditionally called "long $o . "$ The StE spellings of words in this set include final $o(g o, s o)$, oa (oak, road), oe (toe, sloe), o+C+e (rope, home), ol (old, roll), oul (soul, moult), ow (know, own), ough (though), etc.

This sound was not a diphthong in proto-RP, but remained a pure vowel, /o:/. Of words in this set Barnes remarks, "The third long sound of $o$ and $o a$ of English words such as bold, cold, fold, more, oak, rope, boat, coat, becomes the diphthong wo of the fourth and third short [back] sounds in the Dorset dialect, in which those words are buold, cuold, vuold, muore, woak, ruope, büot, cüot" (Diss., \$27). Several questions, discussed in turn below, arise from this statement: Does this diphthongization affect all words with long 0 all the time? If not, what are the rules (if any) governing which words will or will not have diphthongization? What is the sound of the diphthong described? Does it have the same sound initially as internally?

7.14.1 The wording of Barnes's statement above may imply either that long 0 is always diphthongized in the Blackmore Vale in the way described and that the words listed are merely offered as examples, or, on the contrary, that there are certain words in the Blackmore Vale-words such as those listedin which long $o$ is diphthongized, whereas in other words it remains the monophthong /o:/. An examination of Barnes's spelling practice in 1844 shows that long $o$ is not diphthongized in all words, and that the same word may sometimes have a monophthong, sometimes a diphthong-assuming, that is, that Barnes consistently indicates the diphthongal pronunciation by inserting $u$ or $w$ before the 0 . Barnes's later comments in the 1863 Grammar 
show beyond doubt that long $o$ is not diphthongized in all words: "Dorset is, in many cases, more distinctive than our book-speech, inasmuch as it has many pairs of words, against single ones of our books, and gives sundry sounds to other pairs, that, in English, are of the same sound; so that it withholds from the punster most of his chances of word-play. 'The people told the sexton and the sexton toll'd the bell' is in Dorset 'The people twold the sex'on, an' the sex'on toll'd the bell'” (p. 31, repeated more or less verbatim in the 1886 Glossary, p. 29).

7.14.2 But is it possible to predict when long 0 will be diphthongized and when it will not? The current spelling in StE appears to be irrelevant: many words with $o a$ are diphthongized but others are not; many with $o$ alone are not diphthongized, but some are. The only fixed rule governing diphthongization that I have been able to detect is that, except in gold (see 7.14.5 below), the vowel in -old is always a diphthong (buold, cuold, wold, etc.). Elsewhere the phonetic environment evidently has some effect: after syllable-initial $m$ - or $l$ - the sound is normally a diphthong (but not necessarily so after $\mathrm{cl}$-). Etymology appears to have little or no influence. In these circumstances the only safe course is to trust Barnes's spelling; accordingly I show a diphthong when the $o$ is preceded by $u$ or $w$ and a monophthong when it is not.

7.14.3 As for the sound of the diphthong, when it occurs, Barnes's description (quoted above) suggests that it is a combination of $/ U /$ as in crook and $/ \Lambda /$ as in lull, i.e. $/ U \Lambda /$. Rhymes such as those of coat with cut, shut, and strut and of bone, stone, and alone with words ending in $/ \mathrm{\Lambda} /$ suggest that this is an accurate description. But other rhymes, such as those of hold and rolled with old, cold, mould and other words spelled with no or wo suggest rather that the second element of the diphthong is $/ \mathrm{o}(:) /$, and that of stone with shone suggests that it is $/ \mathrm{p} /$. In his other grammars, moreover, Barnes gives different descriptions of the sound. In the 1863 Grammar (p. 14) it is a combination of / $\mathrm{u} /$ as in food and /o:/ as in rope (if both elements are long), or /uo/ (if both elements are short). In the 1886 Glossary (p. 14), on the other hand, it is a combination of / $\mathrm{u}$ / / as in food and /o:/ as in earth, or /uə/ (if both elements are short). These apparent inconsistencies on Barnes's part 
doubtless reflect a genuine instability in the pronunciation of the diphthong. On balance it seems best to transcribe the diphthong as/ur/, since the weight of evidence favours this interpretation rather than others, and since a second element with schwa is flexible enough to allow some latitude in rhyming \{including occasional rhymes between diphthongized and nondiphthongized long $o$, as in the third stanza of "Keepèn up o' Chris'mas," where cuold and scuold (1844) are rhymed with roll'd\}.

7.14.4 Barnes's use of different spellings for the diphthong in 1844 according to whether it is internal or initial (uo internally, wo initially, as in woak, woats, woaths, wold, i.e. 'oak, oats, oaths, old') suggests that there is a clear difference between the sounds; his decision to abandon the $u$ spellings in later editions and to use wo in all positions may suggest, on the other hand, that any difference is minimal. Uncertainty about the pronunciation of the diphthong when it occurs in initial position is apparent from audio recordings made by current dialect speakers: some give the initial $w$ - full value, pronouncing old as in Stow-on-the-Wold and oak as in woke up; others ignore the $w$ - entirely, giving these words their RP pronunciations /ould/ and /ouk/. Accordingly I transcribe all internal occurrences of the diphthong in Barnes's poems as /uə/; in initial position, however, I use /(w)uə/ to reflect the possibility of realizations with full initial $/ \mathrm{w} /$.

7.14.5 Gold and golden are invariably spelled with oold in Barnes's dialect poems, both early and late. (No other word is spelled with oold.) Gold appears in rhyme only twice (neither occurrence in 1844): on both occasions it rhymes with a word containing the diphthongal / ue/ (vwold and twold). Barnes's spelling implies the pronunciation /guild/; his rhymes, on the other hand, imply /guold/. There is evidently some latitude. I transcribe both words with /u:/ except for the two instances of /uə/ in rhyme.

7.14.6 Ago, go, no ('not any'), so ('and so, therefore'), sloe, and toe are almost invariably spelled with oo or ooe in both early and late editions. I know of only four instances in 1844 in which words in this subset are spelled with a single 0 : go (rhyming with flue) in "The settle an' the girt wood vire"; "no stuone" in "The brook that runn'd by gramfer's"; "no cal" in "Farmer's sons"; and "no scope" in "Eclogue:- Two farms in oone." In every case 
except the last (which looks like an oversight) the spelling is changed in later editions to oo. Rhyme evidence confirms that the vowel in these words is always /u:/. Barnes consistently maintains a distinction between no (the opposite of yes) and noo ('not any'). The former, /no:/, is always spelled no, and rhymes with words ending in /o:/; the latter, /nu:/, is invariably noo (e.g. seven times in the final stanza of "Zunsheen in the winter"). The distinction is nicely brought out in the first and third lines of "The farmer's woldest daeter": “No. No. I bēn't arinnen down / The pirty mâidens o' the town; / Nar wishèn ō'm noo harm" (1844, my italics). Similarly Barnes distinguishes between so (/sə/ or /so:/, according to emphasis, 'to this extent') and zoo (/zu:/ 'and so, therefore').

7.14.7 Forms derived from go do not necessarily keep the /u:/ of the infinitive. For going Barnes's normal practice leads us to expect the form gooèn; in his poems, however, the spelling is always gwâin (1844 and 1847) or gwaïn (later editions), i.e. /gwæin/ (see 7.11.6). To the best of my knowledge goes occurs only twice, in two successive lines of "The shy man": "The bride wer a-smilèn as fresh as a rwose, / An' when he come wi' her, an' show'd his poor nose, / All the little bwoys shouted, an' cried 'There he goes,' / 'There he goes." " Here the rhyme with nose indicates standard proto-RP pronunciation, /go:z/.

7.14.8 There is nothing to indicate that words ending in -ow pronounced $/ \partial v /$ in RP do not normally have the expected proto-RP monophthong, /o:/. In the unstressed second syllable of a disyllable, however, this is generally weakened to /or/, as Barnes points out in the last sentence of $\$ 27$ in the Diss.: "ow at the end of a word as fellow, hollow, mellow, pillow, yellow, mostly become er, making those words feller, holler, meller, piller, yoller." Although $/ \mathrm{r} /$ is normally retained in the dialect (see 8.8.1), Barnes's spelling in the 1844 poems shows that in unstressed endings such as this it may be lost (e.g. in narra and arra for narrow and arrow in "Eclogue: Viairies"). The safest transcription is accordingly / $/ \mathrm{r}] /$. The past tense of verbs with short $o$ in the first syllable, however, is different again. In 1844 
Barnes consistently spells the ending of the past tense of follow and bollow ('shout') -ied or -eed, indicating the pronunciations / vplid/ and /hplid/.\}

7.14.9 The words ending in $o$ or oe listed in 7.14.6 appear to be the only ones with the vowel $/ \mathrm{u}: /$. There is no reason to suppose that other words with this spelling (echo, foe, woe, etc.) do not have proto-RP /o:/, and rhymes with stressed -ow confirm that their vowel is /o:/.

7.14.10 In 1844 over is always spelled awver, a form that occurs only once elsewhere, in the awverzeer in the early eclogue "Rusticus res politicas animadvertens. The new poor laws." Elsewhere the StE spelling is used, apart from three occurrences of awver in "The feair market maid." In the word's only occurrence in rhyme, in the eclogue "Come and zee us in the Zummer" ("Well, aye, when the mowen is over, / An' ee-grass do whiten wi' clover, / A man's a-tired out"), the rhyme with clover suggests that proto-RP /o:/ was acceptable in the Blackmore Vale; but the complete consistency of the spelling auver in 1844 shows that the preferred pronunciation was / $\mathrm{a} /$.

7.14.11 For drove, grove, and rove see the discussion in 7.5.3 above.

7.14.12 For more, which is amongst the words listed in $\$ 27$ of the Diss. quoted at the head of this section, see 7.23.1.

7.14.13 Although sloth has diphthongal / $\mathrm{ov} /$ in RP, the rhyme with swath in "Eclogue:- - The best man in the vield" ("Why when bist teddèn grass, ya liazy sloth, / Zomebody is a-fuoss'd to tiake thy zwath / An' ted a hafe woy back to help thee out") shows that the pronunciation for Barnes was with short $o, / \sin \theta /$.

\{7.14.14 Since don't is always thus spelled (with or without the apostrophe, but with no sign of diphthongization), I transcribe it throughout as /do:nt/. Won't, in contrast, is frequently spelled woon't; I take it that the pronunciation is $/ \mathrm{wu}(\mathrm{i}) \mathrm{nt} /$. \} 


\subsection{The GoOsE set}

The GOOSE set (Wells, 2.2.15) contains words with a stressed syllable that has the vowel / $\mathrm{u}$ / in RP and / $\mathrm{u} /$ in GenAm. The StE spellings of words in this set include oo (hoop, tooth), final o (who), final oe (shoe), $u+C+e$ (rude, tune), $u+C+V($ duty), eau $+C+V$ (beanty), ue (due, blue), en (feud), ew (few, new), iew (view), ui (fruit), ou (you, group), ough (through), etc.

This set offers few problems. There is no reason to suppose that most words with /u:/ in RP did not have it also in the Blackmore Vale.

7.15.1 There are many rhymes in Barnes's poems between words with / u: / and words such as dew, few, new, etc. that have /ju:/ in RP. This might perhaps be taken to imply that "yod dropping," as Wells calls it (pp. 147-48) was a feature in the Blackmore Vale (i.e. loss of $/ \mathrm{j} /$, so that new is pronounced /nu:/, as in GenAm, as opposed to /nju:/, as in RP). But rhymes between /ui/ and /ju:/ are common in StE, as in moon / tune in Wordsworth's "The world is too much with us" (5-8), gloom / perfume in Tennyson's "In memoriam" (95.53-56), or fool/ mule in Robert Browning's "My last duchess" (27-28). In the absence of concrete evidence of yod dropping, therefore, I have assumed that words with /ju:/ in RP have it also in Barnes's poems.

7.15.2 Tune is always spelled tuèn, in both 1844 and later editions. It occurs in rhyme once only, rhyming not with the sound /un/ but with a-doèn (/ədu:ən/) in "Gammony Gaÿ." The only other occurrence of the combination ue that I am aware of in Barnes's poems is in the internal rhyme "Though a-ruèn time's undoèn" in "Tweil" (where a-ruèn = 'rueing'). The rhymes confirm what the spelling suggests, i.e. that tuen is disyllabic. Assuming that the yod is retained, the pronunciation will be / tjuiən/.

7.15.3 In a few words that have / $\mathrm{u}$ / in RP there are other vowels in Barnes's poems: $/ \Lambda /$ in roof (see 7.5.2), prove and move (see 7.5.3); $/ \mathrm{U}$ in moot 'treestump', food and mood (see 7.6.2); /v/ or /u:/ in shoot (see 7.6.3). 
7.15.4 A few words with /ov/ in RP have /u:/ in Barnes's poems: gold and golden (see 7.14.5); ago, go, no ('not any'), so ('and so, therefore'), sloe, and toe (see 7.14.6).

7.15.5 The spellings $y a$ and $d a$ are found frequently in 1844 for you and $d o$ (replaced by the StE spelling in later editions). I take it that ya and da represent the unstressed forms $/ \mathrm{jo} /$ and $/ \mathrm{do} /$.

7.15.6 I have assumed that to may be /tu:/, /tu/, or / to/, depending on stress, as in RP.

\subsection{The PRICE set}

The PRICE set (Wells, 2.2.16) contains words with a stressed syllable that has "long $i$," the diphthong /aI/, in both RP and GenAm. The StE spellings of words in this set include $I$ (the pronoun), $i+C+e$ (bide, ripe), $i+C+C$ (find, child), ie (die), uy, y, ye, and eye (buy, try, dye, eye), igh and eigh (bigh, height), etc.

7.16.1 Barnes's lack of comment on this diphthong suggests that the Blackmore Vale pronunciation would have been the same as that in proto$\mathrm{RP}$, namely $/ \Lambda \mathrm{I} /$, with a more central starting point than the /aI/ of presentday RP (see MacMahon, 5.8.15). In the SW the starting point tends to be more central still, though hard to pin down; the weight of evidence suggests, however, that in Dorset at least the starting point is and was the thoroughly central /o/, producing a diphthong /or/ (as in eMnE) that makes bye and buy sound very similar to boy (see 7.17.1). In accordance with observations on the likely length of the first element by the commentators closest to Barnes's own time, I transcribe the PRICE diphthong as /a:I/.

7.16.2 In words ending in -ire (fire, tire, squire, etc.) the diphthong becomes a triphthong by the addition of schwa as an off-glide, and the $r$ is audible (see 8.8.1), giving the combination the sound / $:$ iər/. Thus fire, with voiced initial $f$ - (see 8.3.1) and audible $r$ is in Barnes's poems /və:ır/. As in StE, words in this subset may be treated as either one syllable or two (see the note in OED s.v. fire, $n$.), a freedom that Barnes uses in accordance with the demands of his metre: "The vier at the upper door" in "Shodon Fiair: The vust piart" (1844) is plainly a disyllabic fire, whereas that in the refrain of "The settle 
and the girt wood vire" must be monosyllabic unless the line is hypermetric. It does not follow, however, that Barnes uses the form vire for a monosyllable and vier for a disyllable, helpful though such a convention would be: in both 1844 and later editions he uses vire in the title of "The settle and the girt wood vire" but vier in the refrain that repeats the wording of the title.

7.16.3 From both its spelling and its pronunciation in StE, spire belongs with the subset in the preceding paragraph. But Barnes's spelling is always speer (in both 1844 and later editions) and his rhymes show that for him it is a member of the NEAR set (see 7.19.2), retaining (or reverting to) the diphthong $/ \mathrm{i} / /+\mathrm{r} /$, which is closer to the monophthongal $/ \mathrm{i} / /+\mathrm{r} /$ from which its vowel descends.

7.16.4 Barnes spells cbild both child and chile and rhymes it with both -ild and -ile (for the rhyme with spoiled see 7.17.1). Both rhymes and spelling show that for him the vowel was /a:I/, as in 7.16.1.

7.16.5 In a number of words with / aI/ in RP Barnes's spelling and rhymes show that the diphthong is replaced by /I/. Notable amongst these words are climb, usually spelled clim or clim' and always rhymed with words in -im; also like (almost always spelled lik' in 1844 when it occurs as an adverb or in the past tense of the verb) and strike (usually strik or strick), both rhymed with words in -ick. Barnes appears to make a clear distinction between lik' (adverb and past tense) and like (infinitive, always spelled like in 1844, implying the usual diphthong, /orI/). In view of Barnes's clear preference in his poems I transcribe all these words (except like, infinitive) with /I/. (For the past tense and past participle of climb see 7.16 .10 below.)

7.16.6 Fly and flies ( $n$. and v.) are in Barnes's dialect poems always vlee and vlees, i.e. /vli:/ and /vliz/. The vowel probably results from the longstanding confusion in English between the verbs fly and flee and the nouns fly and flea (see the comments in OED, svv. flee and flea). For the voiced initial consonant see 8.3.1.

7.16.7 For /i:/ in chime and shine see 7.10.2.

7.16.8 For /e:/ in drive see 7.10.6. 
7.16.9 I have assumed that by (normally /bə:I/) has also an unstressed form $(/ \mathrm{bI} /)$, as in StE. Where readers might opt for either a stressed or an unstressed form, I transcribe by as $/ \mathrm{b}(\partial \mathrm{a}) \mathrm{I} /$.

7.16.10 All tenses of the verb climb belong in the PRICE set in StE, including the past tense and past participle, climbed. In OE, however, climb was a strong verb, belonging to the same class as ring and sing, with the vowel sequence $i$ (present), $a$ (past singular), $u$ (past participle), these vowels all being short, as is still the case with sing, sang, sung. We have already seen that the $i$ in $\operatorname{clim}(b)$ remained short for Barnes (7.16.5), and this applies equally to weak forms of the past tense and past participle, whether the $b$ is dropped (as in the 1844 version of "The girt woak tree that's in the dell"- "Var in thik tree, when I wer young / I have a-clim'd, an' I've a-zwung") or whether it is retained (as in the later versions' “a-climb'd”). But Barnes's usual preference is for the strong forms that survived in the Blackmore Vale: past tense clomb and past participle a-clum ("The wold waggon," 1844), a-clom ("The wold waggon," later editions), or a-clomb ("When we wer young together"). The rhyme with a-come in "When we wer young together" and the 1844 spelling, -clum, show that the vowel in the past participle must have been $/ \Lambda /$. The rhymes with come, home (see 7.5.2, 7.14.3) and swum suggest the same for the past tense (given as clumb in the 1844 Glossary), even though it is spelled clomb in the poems, both in rhyme and outside it. I transcribe the strong forms of both the past tense and past participle of climb, accordingly, as $/ \mathrm{kl} \Lambda \mathrm{m} /$.

7.16.11 Since the vowel in grist is short in RP, the apparent rhyme between hoist and grist in the opening lines of the last stanza of "Naïghbour plaÿmeätes” looks odd at first sight: “An' still the pulley rwope do heist / The wheat vrom red-wheeled waggon beds. / An' ho'ses there wi' lwoads of grist, / Do stand an' toss their heavy heads". OED notes that the vowel in grist was long in $\mathrm{OE}$, but was shortened in $\mathrm{ME}$ (as in fist from OE fýst). But some of the 16th- and 17th-century spellings of grist recorded there (greest, greist, and griest) suggest the survival of $\mathrm{ME} i$ into the MnE period. Since there is no pattern of half-rhyme in "Naighbour plaÿmeätes," it is reasonable to assume a full rhyme between heist ('hoist') and grist, with the $\bar{i}$ of the latter first diphthongized and having then undergone the CHOICE-PRICE merger 
(see 7.16.1 above and 7.17.1 below). I take it, therefore, that grist is to be pronounced /grərist/ rather than /grist/.

7.16.12 The verb to leine appears twice in Barnes's poems, on both occasions rhyming with behine ('behind'): in the second stanza of "The welshnut tree" ("A-leävèn fāther indoors, a-leinèn / In his girt chair, in his èasy shoes, / Ar in the settle so high behine en") and the second stanza of "The huomestead a-vell into han" " "An' in the archet out behine, / The apple-trees in row, John, / Did swây wi' upright stems, ar leine / Wi' heads a-noddèn low, John," 1844 and 1847). The sense is evidently "to lean," but the rhyme with bebine requires the vowel of line rather than that of lean. Barnes's 1886 Glossary records "LINE. To lean" with no etymology; the Glossary in 1847 is more helpful, both showing the length of the vowel ("Line") and offering an etymology ("A-S. hlynian," a variant, I take it, of bleonian, from which StE lean is derived). As with most other words in the PRICE set the vowel will be /ə:I/, hence / bə:In/.

\subsection{The CHOICE set}

The CHOICE set contains words with a stressed syllable that has the diphthong /or/ in both RP and GenAm, almost all "ultimately loan words, mainly from Old French" (Wells, 2.2.17). The StE spellings of words in this set are oi (noise, voice, coin, etc.) and oy (boy, joy, etc.).

7.17.1 As Wells points out, “The CHOICE vowel seems to have merged with PRICE in the popular speech of parts of the south of England.... The same merger can be found in Newfoundland, the West Indies and Ireland" (3.1.11); or, again, "Some conservative rural accents reflect a merger or partial merger of the two diphthongs"(2.2.17). Such was evidently the case for Barnes, who draws attention to this feature in $\$ 26$ of the Diss., who frequently rhymes words from one set with words from the other, and whose early spellings (e.g. spwile, twile, pwison) point up the similarity. It follows that the pronunciation of the CHOICE diphthong in Barnes's dialect will normally be the same as that of the PRICE diphthong, i.e. /orI/ (see 7.16.1). (For the $w$-glide introducing the diphthong see 8.16.3.) 
7.17.2 Noise, quoits, rejoice, and voice are always spelled with $\hat{a} i$ (1844) or ä̈ (later editions); evidently they have the same diphthong as the subset maid, paid, vein, etc., that is, /æI/ (see 7.11.6).

7.17.3 The spelling of joy and its derivatives varies between oy, as in StE, and ay or äy in Barnes's poems, and it is rhymed both with boy (see 7.17.4) and with words from the May, hay subset (see 7.11.6), showing that the diphthong varies between /ə:I/ and /æI/.

7.17.4 Unlike Jennings, who spells boys with ay (in bways, rh. ways), Barnes always uses oy for the diphthong in boy and its derivatives. When boy rhymes in Barnes's poems with words that are spelled with ay in StE, the spelling of the latter is always changed to conform with the oy in boy, not vice versa. The logical conclusion is that the diphthong in boy is stable (pronounced/ail/, as described in 7.17.1), whereas that of the rhyme words in ay, $\hat{a} y$ or äj varies. (For the intrusive /w/ in bwoy see 8.16.3.)

\subsection{The MOUTH set}

The MOUTH set (Wells, 2.2.18) contains words with a stressed syllable that has the diphthong /av/ in both RP and GenAm. The StE spellings of words in this set are ou (bouse, out, bough, bour, etc.) and ow (now, down, flower, etc.).

7.18.1 The current pronunciation of this diphthong, /av/, "appears to have been a twentieth-century development" (MacMahon, 5.8.18, p. 467). There is abundant evidence that in Dorset in the 19th century the diphthong was /o:u/, very similar to that in current RP know.

7.18.2 In the sequences our and ower (as in hour and flower) the diphthong becomes a triphthong, as in StE. The pronunciation in Barnes's poems will accordingly be /aruər/, which, like fire etc. (see 7.16.2), may be treated as one syllable or two as the metre demands.

7.18.3 As pointed out in 7.13.8c, Barnes's comments on fought (Diss., \$24) and his rhyming of it with about, out, and stout (see Key-Rhymes 111) show that in his poems it has the diphthong / a:u/. 
7.18.4 A few words with the vowel $/ \Lambda /$ in StE have instead the /oru/ diphthong of words in the MOUTH set in Barnes's poems, either always, as in the case of rut (n.), and strut ( $v$., and in the adv. a-strut 'sticking out') (see 7.5.4), or usually, as in the case of dust and crust (see 7.5.5).

\subsection{The NEAR set}

The NEAR set (Wells, 2.2.19) contains words with a stressed syllable that has the diphthong /ra/ in RP (with or without a following /r/) and / rr/ in GenAm. The StE spellings of words in this set include eer (beer, peer, etc.), ere (here, mere, etc.), ier (bier, pier, etc.), eir (weir, weird, etc.), and ear (fear, year, etc.), but spellings are not a reliable guide: here belongs with NEAR, but there and where with SQUARE; and the tears in one's eyes are with NEAR, but the tears in one's clothes are with SQUARE.

It is not entirely clear at what point the vowels in the NEAR and SQUARE sets developed into diphthongs under the influence of the following $/ r$, either in proto-RP or in the SW. In the absence of conclusive evidence to the contrary, I treat all words in these sets in Barnes's Blackmore Vale poems as diphthongs (except where noted below), but (in contrast to RP) without loss of the following / $\mathrm{r} /$ (see 8.8.1).

7.19.1 There is no evidence to suggest that the majority of words in the NEAR set do not have a diphthong very similar to RP / r / in Barnes's poems. In Barnes's contribution to EEP Ellis's transcription shows the same diphthong, with a slightly higher starting point (/ior/), in here, hear, and near (cwl 365). I follow Barnes's contribution to EEP in using /ior/, except where noted below.

7.19.2 As noted earlier, rhyme evidence shows that spire has /irr/ in Barnes's poems, as opposed to RP / агə/ (see 7.16.3).

7.19.3 In popular caricatures of west-country accents ear, hear, here, and year are homophones, all with the vowel sequence of the NURSE set (7.9 above), and all with initial $/ \mathrm{j} /$ (for which see 8.5 .5 below), thus $/ \mathrm{jar} / \mathrm{r}$. The spelling yers for ears in the 1844 version of "Uncle an' ānt" and the rhyming of year with stir and Hazelbur (/ha:zəlbə:r/, still the local name for Hazelbury Bryan) 
in "Bob the fiddler" show Barnes's familiarity with pronunciations of this type; but other evidence from rhyme suggests the coexistence in his dialect of pronunciations with /irr/.

7.19.4 Whereas hear belongs in the NEAR set in StE, its past participle, heard, belongs in the NURSE set. Rhyme evidence shows that in Barnes's poems (in which it is usually, but not always, spelled heärd) it may have /ərr/, /jərr/ or /ior/ (see 7.9.6).

7.19.5 There is some crossing over between the NEAR and SQUARE sets in the SW, as in other regional dialects of English (see Wells, 2.2.20, p. 157). In Barnes's case rhyme evidence shows that rear and weir have crossed over to the SQUARE set, with / عər/ in place of /irr/; and although queer does not appear in rhyme in his dialect poems, Ellis's transcription in clause 5 of Barnes's cs suggests that it, too, has / عər/. All three of Barnes's crossovers from NEAR to SQUARE are supported by other witnesses for the SW.

\subsection{The SQUARE set}

The SQUARE set (Wells, 2.2.20) contains words with a stressed syllable that has the diphthong / $\varepsilon$ / / in RP (with or without a following /r/) and / $\mathrm{r} /$ or $/ æ r /$ in GenAm. The StE spellings of words in this set include air (fair, hair, etc.), are (bare, care, etc.), ear (bear, wear, etc.), eir (heir, their, etc.), ere (there, where, etc.), and $a r+V$ (Mary, various, etc.); some words with these spellings belong, however, with the NEAR set (see 7.19). On the question of diphthongs versus pure vowels see the introductory paragraphs to the NEAR set.

7.20.1 Most words with / $\varepsilon$ / in RP have / $\varepsilon$ :ər/ or / $\varepsilon ə r /$ in both Elworthy's records for West Somerset (DWS, \9) and Widén’s for Hilton (SDD, \$29.3), i.e. the same diphthong as in RP (with optional lengthening of the first element) but without loss of the following / $r$ / (see 8.8.1). I assume that the same holds for Barnes's poems; where there is no conflicting evidence, accordingly, I transcribe the sound in SQUARE words as / عər/.

7.20.2 Barnes's habitual spelling of words in -air and -are (fair, pair, mare, share, etc., the FAIR and MARE subsets, as they might be called) is with -iair 
and -iare (1844) or -eäir and -eäre (later editions), thus fiair or fiare, piair, miare, shiare (1844), feäir, peäir, meäre, sheäre (later editions). These spellings suggest the introduction of an $i$-glide, with possible reduction of the following diphthong to $/ \partial /$, resulting in the crossover of words in these subsets to the NEAR set, with the diphthong $/ \mathrm{i} / \mathrm{H} / \mathrm{r} /$. But in Barnes's poems words from these subsets are consistently rhymed with SQUARE words, never with NEAR words, showing that the introductory $i$-glide in the FAIR and MARE subsets does not result in weakening of the following diphthong to $/ \mathrm{\partial} /$, but leads instead to the creation of a triphthong $+/ \mathrm{r} /$, i.e. $/ \mathrm{j}$ kər/.

7.20.3 Barnes's habitual spelling of where in 1844 is wher, with only occasional instances of StE where; that of there (more often than not) and their (almost always) is ther. (In almost every instance these spellings are replaced by the StE spellings in 1879.) The spellings in -er suggest pronunciation with /or/ rather than / عər/, and there is some support for this in the rhyme togither/ ther (in "Eclogue:- -Two farms in oone"). On the other hand, Barnes's normal rhymes for where and there are orthodox rhymes with other words from the SQUARE set. It would appear that for their, where, and there pronunciations with /ər/ and with / عər/ were both acceptable in his dialect.

7.20.4 Whereas scarce belongs in the SQUARE set in RP, the /r/ is lost in Barnes's poems through the influence of the following / s/ (see 8.8.5, and cf. 7.9.5). Introduction of the $i$-glide discussed in 7.20.2 and loss of $/ \mathrm{r} /$ before /s/ give rise to Barnes's spellings skia'ce (1844) and skeäce (later editions); and it is clear both from these spellings and from the rhyme with less in "Eclogue:-Two farms in oone" ("Tha hadden need miake poor men's liabour less, / Var work a'ready is uncommon skia'ce") that in Barnes's dialect scarce is a member of the FACE set, with the diphthong /je/ (see 7.11.1).

7.20.5 Barnes's normal spellings of the word air itself are air (1844) and aïr (later editions), suggesting a distinction in sound from words in the FAIR subset. Though the word occurs frequently in Barnes's poems, to the best of my knowledge it occurs only twice in rhyme, both times rhyming with prayer (spelled prä̈'r, in “The leädy's tower" and "The echo"). It is reasonable to 
deduce from this evidence that the vowel in air is /æI/ (see 7.11.6) with following $/ \mathrm{r} /$, giving the complete word the sound /ærr/. Occasional instances of the spelling aier suggest, however, that pronunciation with a triphthong, /æır/, is also possible (cf. fire, 7.16.2). \{An alternative explanation might be that air is always a triphthong, irrespective of how it is spelled, and that, like other triphthongs such as ire and our, it may be pronounced as either one syllable or two as the rhythm requires.\}

7.20.6 The spelling -âir and/or -aïr also occurs occasionally in fair, chair and stair. Since, however, the forms chair (in "The vierzide chairs") and feair (in "The surprise") both rhyme with there, we may reasonably take it that the spellings with -air and -aïr are oversights, and that these words are all pronounced with final / $\varepsilon ə r /$.

7.20.7 The rhyme beware/ var in "Havèn oon's fortun a-tuold" ("An' then she tuold me to bewar/O' what the letter $M$ stood var.... An' Poll too wer a-bid bewar / O' what the letter F stood var') suggests that the stressed syllable of beware is not /weər/ but /war/, as in the START set. (For var see further 7.22.3.)

\subsection{The START set}

The START set (Wells, 2.2.21) contains words with a stressed syllable spelled with ar (or occasionally er or ear) that has the sound /a:/ in RP in final position or followed by a consonant (/arr/ when final $-r$ is followed by a vowel) and /ar/ in GenAm: far, farm, cart, heart, hearth, sergeant, etc.

7.21.1 There is no evidence in Barnes's poems to suggest that the vowel in the majority of the words in the START set differs from that in the BATH set (with a following $/ \mathrm{r} /$ ). Accordingly my normal transcription for the ar sequence in this set is /arr/ (see 7.7.1 and 8.8.1).

7.21.2 Barnes's spelling of the words card (but not cart), garden, and part (iar in 1844, eär in later editions, thus g(b)iarden, kiard, piart, and geärden, ceärd, peärt), shows that they form a subset in which an introductory $i$-glide gives rise to the sequence /ja:r/. The dialect word spiarde ('spade', replaced by speäde in 
later editions) appears to belong to the same set. Rhyme confirms that the stress is on the second element. It may seem odd that Barnes distinguishes the opening sequence in card (/kjaird/ with an introductory $i$-glide) from that in cart (/ka:rt/ with no glide), but Elworthy notes the same distinction in West Somerset (DWS, \$2). The records in SED suggest, however, that the introductory $i$-glide has died out in all words in the SW by the mid 20th century.

7.21.3 Garden has (apparently) an alternative pronunciation, /giordən/, with the /iər/ sequence of the NEAR set, beside /gjairdən/ (as in 7.21.2). This assumes that heärd en / giarden in "Faether come huome" (1844; later editions geärden) is a true rhyme ("The pig got out/This marnen; an' avore we zeed ar heärd en, /'E runned about an' got out into giarden, / An' routed up the groun' zoo wi' his snout"), and that beärd has here its NEAR-set pronunciation (see 7.9.6).

7.21.4 Hearth belongs with the START set in StE (and indeed in Barnes's contribution to EEP for Winterborne Came, cwl 405), but both spelling (beth or he'th) and rhyme show that in Barnes's poems it is $/ \mathrm{h} \varepsilon \theta /$, not /ha:r $\theta /$, making it a member of the EARTH-BIRTH-MIRTH subset (see 7.9.5).

7.21.5 Several subsets that do not belong with the START set in StE have the sequence /arr/ in Barnes's poems. These sets include the following:

a) words spelled with or or ar pronounced /o: in RP (corn, storm, warm, etc.; see 7.22.1-2);

b) some words spelled with er or ear pronounced /a:/ in RP (serve, learn, herb, etc.; see 7.9.2);

c) the verb carry and its derived forms (see 7.3.3).

7.21.6 Barnes's spelling of arm in 1844 (yarm, replaced by eärm in later editions) shows that it is preceded by an introductory $i$-glide, resulting in the sequence /ja:r/ (cf. words beginning with earn in StE; see 7.9.3). 


\subsection{The NORTH set}

The NORTH set (Wells, 2.2.22) contains words with a stressed syllable spelled with or or ar that has the sound /o: / in RP in final position or followed by a consonant (/orr/ when final $-r$ is followed by a vowel) and / or/ in GenAm, "or rather in that variety of GenAm that retains the opposition between /or/ and /or/" (p. 159): or, for, corn, horse, storm, war, warm, warp, etc.

7.22.1 As Barnes himself points out, “The second long [back] sound of $o$ in such words as corn, for, horn, morning, storm, becomes the first long [back] one, a, making carn, var, harn, marnen, starm" (Diss., \$25). The persistence of this feature up to the present time is shown by Wells's comment, "There is a large patch of Wessex where (in old-fashioned rural dialect, at least) we find the vowels of NORTH and START merged" (4.3.7, p. 347). We may accordingly expect that all words in the NORTH set (apart from those noted in 7.22.4) will have the START sequence, /arr/, in Barnes's poems. This expectation is confirmed both by his rhymes and by the spelling of 1844, in which the following words (and their derivatives) are all spelled with ar for StE or: corduroy, cork, corn, corner, for, forfeit, forget, forgive, fork, forlorn, former, forsake, horn, lord, morn(ing), mortal, mortar, nor, northern, or, orchard, scorn, short, snort, sort, storm, story, thorn (1844: cardrây, cark, carn, carner, var, farfeit, vargit, vargi'e, fark, varlarn, farmer, varsiake, harn, lard, marn(en), martal, martar, nar, narthern, ar, archet, scarn, shart, snart, sart, starm, starry, tharn). Accordingly I transcribe the or sequence in all such words as /a:r/.

\{The rhyming of story (from the list above) with var ye ("A bit o' sly coortèn," "The times") and barry ('borrow," "The witch") confirm its pronunciation in those poems with $/ \mathrm{a}(\mathrm{i}) \mathrm{r} /$, but Wells classifies it as a FORCE word (see 7.23.1); and this is confirmed in "Bob the fiddler" both by the spelling story (even in 1844) and the rhyme with avore ye / glory. Assuming that this is a true rhyme, story can have either NORTH or FORCE pronunciation in the dialect; glory has the latter (/uər/).\}

7.22.2 Though they are not specifically mentioned in Barnes's comment in \$25 of the Diss., words with ar pronounced / $\mathrm{o}(\mathrm{r}) /$ in RP likewise have the sequence /arr/ in his poems, as shown by rhymes such as warm/ harm and swarm/farm. 
7.22.3 When particles such as for, or, and nor are stressed, they will have the expected sequence, /a:r/, as implied by the rhyme bewar / var in "Havèn oon's fortun a-tuold". When, however, they are only partly stressed or unstressed (as is frequently the case), it seems probable that the sequence /a:r/ is reduced to /ar/ or/or/, as in Barnes's cs for EEP, clauses 10 and 12 (for), 7, 10, and 14 (or), and 1 (nor). The degree of stress in any particular case is, of course, a matter for the reader to decide. Barnes's own varied practice confirms the variability in pronunciation; but his complete abandonment of the ar spellings from the 1859 collection onwards, in order to give "the lettered Dialect more of the book-form of the national speech" (Preface, p. [iii]), can have no bearing on the pronunciation.

7.22.4 Words with the sequence ors or orth in StE pronounced /o:s/, / $: 0 /$ in $\mathrm{RP}$ and /ors/, /or / in GenAm are an exception to the general rule set out in 7.22.1. Loss of $/ \mathrm{r} /$ before $/ \mathrm{s} /$ and $/ \theta /$ (see Diss., \$35) has led to retention of short $o$ in the sequences $/ \mathrm{ps} /$ and $/ \mathrm{p} \theta /$. This is evident from Barnes's spellings: hoss or ho'se for horse (passim), and no'th for north (in "The shep'erd bwoy," though North is retained in proper names; and contrast narthern or northern with voiced /ð/ preceded by /a:r/ in "The blackbird" and other poems). The pronunciation with / ps/ is confirmed by rhymes for horse, always with words ending in -oss. As with horse so with Dorset: in spite of the popular perception that to its inhabitants the county is /darzot/, Barnes in his poems always uses the spelling Do'set. The inescapable conclusion is that for Barnes the county was /dpsət/.

7.22.5 Whereas quarrel, sorry, and other words with -arr-or -orr-belong in the CLOTH set in RP and GenAm, rhymes show that in Barnes's poems they behave like words in the NORTH set, possibly with /ar/ or /ar/ rather than /arr/ for /o(:)r/. SED shows that in four of its five Dorset locations in the 1960s the pronunciation with short /a/ was still the norm in quarry (IV.4.6). 


\subsection{The FORCE set}

The FORCE set (Wells, 2.2.23) contains words with a stressed syllable spelled with or $+C$, ore, oar, oor, or our that has the sound /o: in RP (/orr/ when followed by a vowel) and /or/ in GenAm, "or rather in that variety of GenAm that retains the opposition between /or/ and /or/" (p. 160): ford, porch; before, bore, more; boar, hoarse; door, floor; four, mourn, course, source, etc.

7.23.1 Present-day RP speakers who read Barnes's Diss. are likely to be puzzled by finding more listed (in \$27) as having the same vowel as bold, oak, rope, coat, etc., since those words belong in the present-day GOAT set whereas more belongs in the FORCE set. Evidently more and other words in the current FORCE set preserved earlier close $\bar{o}$ (/o:/) in proto-RP (see 7.14 above), and this is reflected in Ellis's transcriptions of some of these words in Barnes's contribution to EEP, e.g. avore, bored, and board. Nevertheless (as discussed in 7.14.1-3) the more usual transcription is /uə/ (/uər/ when the vowel is followed by $r$, as in the present instance), and this is shown in Ellis's transcriptions of afford, more, sore, door, and swore, all of which have /uər/. Since, moreover, the distinction Barnes makes between the sound in avore and that in door in his report on Winterborne Came for EEP is not reflected in his poems, where words in -ore are rhymed frequently with words in -oor, I transcribe all words in the FORCE set with /uər/, except where indicated below.

7.23.2 The rhyme door / four in "Come an' meet me, wi' the childern, on the road" ("Zoo when clock-bells do ring vour, / Let em warn ye out o' door") is unsurprising to present-day readers, since these words rhyme in StE). But Barnes's preferred spelling of four is vower or vow'r rather than vour (which it has only rarely), and the spellings with ow suggest that four normally belongs in the MOUTH set in his dialect, with the pronunciation /ouør/, like flower, bour, etc. (see 7.18.2). This accords with Barnes's report for Winterborne Came in EEP, where four is transcribed as /vəưr/ (cwl 420). It is not clear whether four has an alternative pronunciation, /vuər/, or door an alternative, /dəruər/, either of which would allow an exact rhyme, or whether the rhyme is in this instance only approximate. 
7.23.3 The rhyming of hour with floor (in "Eclogue:-_Viairies") and with core (in "The geäte a-vallen to") looks more unusual to present-day readers, but in Barnes's dialect it is similar to that of door with four: a FORCE word (/vluər/, /kuər/) is rhymed with a MOUTH word (/əuər/), and it is not clear whether alternative pronunciations allow an exact rhyme or whether the rhyme is approximate. \{Since floor is invariably spelled with on in 1844 (whether as vlour or vlou'r), its pronunciation with / aruər/ seems probable.\}

7.23.4 In the rhyme avore / lower in "Eclogue:-The times" (if the Corn Laws were abolished, farmers would pay less rent, and prices "wood be low'r/Var what ther land woo'd yield, an' zoo ther hands / Wou'd be jist wher tha wer avore") it is reasonable to assume that the stressed vowel in lower has its expected pronunciation, /o:/ (see 7.14.8). In normal circumstances the addition of the comparative suffix / or/ would make lower disyllabic; but both metre and the spelling low'r (in both 1844 and later editions) suggest that the word is here treated as monosyllabic, hence /lorr/ rather than /lo:ər/. This would permit an exact rhyme with /ovorr/, as in Barnes's report on Winterborne Came for EEP (see 7.23.1 above).

7.23.5 Whereas morning and mourning have become homophones in RP, they remain distinct in Barnes's poems, the former (/marnən/) belonging to the NORTH set (see 7.22.1), as in the "marnen zun" of "The Spring" (1844), the latter (/muərnən/) belonging to the FORCE set, as in the "moornen" (1844) or "murnèn" (later editions) kerchief worn by Jenny in "The ruose that deck'd her breast" when her Robert died. But rhymes with burn, kern, and turn (supported by the spelling, usually murn) show clearly that Barnes's preferred pronunciation for mourn is /morn/, making it in his dialect a member of the NURSE set.

7.23.6 Loss of $/ \mathrm{r} /$ before $/ \mathrm{s} /$ affects words with the sequence oars or ours just as it does words with ors (see 7.22.4), but with differing results.

a) In hoarse, which occurs to the best of my knowledge only in the "huosse" (1844) or "whoa'se" (later editions) cuckoo of "I got two vields," the 1844 spelling suggests diphthongization of long 0 , which I transcribe as /uə/ (see 7.14.3), giving / huəs/. 
b) In course, both in of course ("in coose" or "in coo'se" in Barnes's poems) and in the verb to course ('to chase'), both spelling and rhyme (e.g. with woose 'worse' in "A witch") point to the sound / ku:s/.

\subsection{The CURE set}

The CURE set (Wells, 2.2.24) contains words with "the stressed vowel /uə/ in conservative RP" ("now increasingly being replaced by /o:/") "and the sequence /ur/ in GenAm" (p. 162). This includes some words with the spelling oor (e.g. moor, poor), some with our (e.g. tour, your), some with ure, $u r+V$, or ury (e.g. pure, sure, curious, rural, fury), and some with eur (e.g. Europe).

7.24.1 It is evident from rhyme that Barnes does not distinguish in his poems between the vowel of the FORCE set and that of the CURE set: more (from the former) rhymes frequently with poor and sure (both from the latter); sure rhymes with more (from the former), poor (from the latter), and $d o$ er (a near homophone of dour, from the latter). The length of the first element of the sequence / uer/ appears to be variable, tending towards long in CURE words and short in FORCE words. The long first element would accord with the transcription/Suiər/ for sure in Barnes's contribution to EEP (cs clause 4), and would make an exact rhyme with do er (/du: or/); but since the difference is insufficient to prevent the rhyme with more (/muər/), it makes sense to use for CURE words the transcription $/ \mathrm{u}(:)$ ər/.

7.24.2 The pronoun your is frequently unstressed, and this is sometimes shown in 1844 in the spellings yer and yar (all replaced by StE your in later editions). Whenever the word is unstressed, irrespective of its spelling, I take it that the pronunciation is /jər/, as still frequently heard today. 


\section{CONSONANTS}

Consonant sounds are generally less troublesome than vowel sounds; the comments Barnes makes on them in his grammars are for the most part clear and precise; and his spelling (in both early and late editions of his poems) is usually a helpful guide to their pronunciation. Consonant sounds that are not discussed in this section may be assumed to have the same pronunciation as in RP; differences from RP in single consonants and consonant clusters in Barnes's poems are listed below in alphabetical order of the key consonant(s) concerned.

\section{$8.1 C$}

As shown by Barnes's spelling of cuckoo (invariably gookoo, in both early and late editions) $/ \mathrm{k} /$ is occasionally voiced to $/ \mathrm{g} /$. For the reverse process see 8.4.2 below.

\section{$8.2 D$}

8.2.1 "An open palate letter is sometimes substituted for a close one, $r$ for $d$ ... as parrick, a paddock" (Diss., \$39); in phonemic terms /r/ replaces /d/ in some words, as shown by Barnes's spelling, parrick (early) or parrock (later editions).

8.2.2 ' $d$, after $n$, as in an', and; boun', bound; groun', ground; roun', round; soun', sound; is commonly thrown out, as it is after l: as in veel, for field" (Diss., \$30). This loss of final /d/ in the consonant clusters /nd/ and / ld/ is reflected in frequent rhymes between words ending in -ound in StE and words ending in -own, and between field and words ending with the sound /irl/. But "commonly" does not mean 'always'; Barnes's more usual spellings are with -nd or - $l d$; and the rhymes round / crown'd ("The shepherd o' the farm") and field/ wheel'd ("Hallowed pleäces") show that retention of final /d/ is sometimes obligatory. My policy, accordingly, is to transcribe these two clusters outside rhyme as /n/ and / $/$ when Barnes omits the final consonant, and as $/ \mathrm{n}(\mathrm{d}) /$ and $/ \mathrm{l}(\mathrm{d}) /$ when he retains it, showing that the final $/ \mathrm{d} /$ is optional; in rhyme I use $/ \mathrm{n} /, / \mathrm{nd} /, / 1 /$, or $/ \mathrm{ld} /$ as the rhyme requires. 
8.2.3 In a note added to $\$ 29$ in the 1847 Diss. (repeated in the 1863 Grammar, p. 16) Barnes points out the substitution of /ð/ for /d/ in ladder and bladder. This substitution is consistently shown in 1844 (e.g. in the "lather" that plays such an important part in "What Dick an' I done" and the "blathers" hanging round the walls in "The settle an' the girt wood vire"); but StE spelling is usually restored in later editions.

8.2.4 In 1844 both spelling (always archet) and rhyme (archet / sarch it, "The welshnut tree") show that the final consonant of orchard is not /d/ as in RP but voiceless $/ t /$. (For the pronunciation of the first syllable in orchard see 7.22.1.) In later editions the spelling is usually orcha'd (which is likely to mislead present-day readers into thinking the pronunciation is /ortfəd/, as in $\mathrm{RP}$ ); since, however, Barnes retains the rhyme with sarch it (in spite of respelling orchard as orcha't), we may reasonably assume that the pronunciation is still /a:rt〕t/.

\section{$8.3 \mathrm{~F}$}

8.3.1 The voicing of initial fricatives, in particular /f/ to $/ \mathrm{v} /$ and $/ \mathrm{s} /$ to $/ \mathrm{z} /$ (for which latter see 8.9.1), is one of the best-known features of SW dialects (see Wells, 4.3.6, p. 343); Wakelin, indeed, calls it (as far as the written record is concerned) "the SW feature par excellence" (I.4.2, p. 29). In Barnes's words, " $f$ of English words is commonly rejected for its smooth kinsletter $v$ before a vowel or liquid in the Dorset dialect, in which fast, fetch, feed, find, fire, for, foot, from, become vast, vetch, veed, vind, vire, var, voot, vrom"; but "some English words beginning with $\mathrm{f}$ before a consonant, as fling, friend, retain $f$ " (Diss., $\$ 31$; see $\$ 17$ for Barnes's explanation of the terms rough and smooth). Not all eligible words always have voiced $f$ (fan, not van; fall = 'autumn', as against vall, verb; farmer (1844) / former (later editions) = 'former'); but this will not cause difficulty since Barnes retains the spelling $v$-for voiced $f$-in all editions of the poems. Other commentators have noted instances of loan words that are affected by voicing: Widén, for example, recorded /v/ in several loan words from French in the mid 20th century, including face, farm, feast, fine, and finish (SDD, \$74.1b); but Barnes spells all these words with $f$ and is remarkably consistent in showing that for him it is only in Germanic 
words that initial /f/ is voiced. He spells this out plainly in both the 1863 Grammar (p. 16) and the 1886 Glossary (p. 8): “... the Dorset does not hold $V$ for $F$ in words that are brought in from other and not Teutonic languages. We must say Factory, false, family, famine, figure, in Dorset, as well as in English."

8.3.2 "The preposition of loses its $f$ and becomes $o$ ' before a consonant" (Diss., §31). This self-explanatory comment is borne out many times in Barnes's poems, e.g. in the titles "A bit o' fun," "Keepèn up o' Chris'mas," "The music o' the dead," etc. I take it that the reduced (and unstressed) $O$ ' is merely a schwa in pronunciation and transcribe it as $/ \mathrm{\partial} /$.

8.3.3 The possessive combinations of en, of it, of us, of them are normally abbreviated to $o+$ the final consonant (o'n, o't, o's, o'm). Barnes's preferred spelling of these combinations in 1844 is with $\bar{o}^{-}\left(\bar{o}^{\prime} n, \vec{o}^{-} t, \bar{o}^{\prime} s, \bar{o}^{\prime} m\right)$, showing that the 0 is lengthened. I accordingly transcribe it as /o:/ in such combinations, even when (as usually in later editions) the length mark is omitted.

\section{$8.4 G$}

8.4.1 The occasional spelling ghi, as in ghiame, ghiarden, and ghirt, may appear at first sight to suggest aspiration after initial /g/; more probably, however, the $b$ is inserted between $g$ and $i$ (as in Italian) to show that the initial consonant is the stop $/ \mathrm{g} /$ as opposed to the fricative $/ \mathrm{d}_{3} /$.

8.4.2 Devoicing of $/ \mathrm{g} /$ occurs in some environments, as suggested by the spelling fakket for faggot in the 1844 and 1847 versions of "Guy Faux's night" and "What Dick an' I done" (respelled as in StE in later editions). For the reverse process see 8.1 above.

8.4.3 "The termination ing of verbal nouns such as singing and washing, as well as imperfect participles, is in Dorset en; as in a beäten, a beating; writen, writing" (Diss., $\$ 42)$. In the poems Barnes usually spells this -en ending -èn. For a discussion of the pronunciation see 7.1.5.

8.4.4 Present-day audio recordings show uncertainty amongst readers as to whether the initial $g$ in gilcup is hard $(/ \mathrm{g} /)$ or soft $\left(/ \mathrm{d}_{3} /\right)$. The etymological 
comment Barnes supplies in the 1886 Glossary shows that /g/ is correct: "GIL'CUP or Giltycup. Giltcup; the buttercup, (ranunculus bulbosus); so called from the gold-like gloss of its petals."

\section{$8.5 H$}

8.5.1 "In the working-class accents of most of England, H Dropping prevails. That is to say, the $[\mathrm{h}]$ of standard accents is absent: words such as bit, happy, hammer, hedge, begin with a vowel" (Wells, 3.4.1, p. 253). But Somerset and parts of Wiltshire and Dorset " are traditionally '/h/-areas', i.e. areas where strong aspiration is retained, as distinct from most other dialect areas, where it is lost" (Wakelin I.4.2, p. 31). Since there is no mention of $\mathrm{H}$ Dropping in Barnes's grammars, and no sign of it in either his earlier or his later spelling system (except in the unstressed personal pronouns 'e, 'er, etc., where loss of initial $/ \mathrm{h} /$ is as common in StE as in any class or regional dialect), we may reasonably deduce that the Dorset represented in Barnes's poems is a traditional $/ \mathrm{h} /$-area, where the $/ \mathrm{h} /$ is retained in hit, happy, etc.

8.5.2 In contrast to the $\mathrm{H}$ Dropping that is common elsewhere, Barnes points out that initial $/ \mathrm{h} /$ from $\mathrm{OE}$ is often retained in his dialect in words that have lost it in StE, and introduced in others that did not have it in OE. In the 1886 Glossary he gives a list of some two dozen words beginning with $r$ - in which the initial consonant is "hard breathed" in Dorset, i.e. words which begin with the combination /hr/ rather than simply /r/ (pp. 9-10). After the list Barnes supplies a specimen sentence containing a whole series of aspirated rs: "He hrode by hroughest hroads, and hrugged hrocks where hrobbers hroamed." But there is no mention of aspirated initial $r$ in the Diss., and Barnes does not use the spelling $h r$-for initial $r$ - in any edition of his poems. Since it appears that aspirated initial $r$-was a feature of the dialect that Barnes chose not to portray in his poems, I do not use the combination $/ \mathrm{hr} /$ in my phonemic transcripts of the poems.

8.5.3 If there is aspiration in the dialect Barnes describes in sounds that are not aspirated in StE, it is reasonable to suppose that initial wh- (from OE $h w-)$ is aspirated in the dialect in words such as what, when, where, which, why, etc. that were formerly pronounced with / hw/ in RP, and are still so 
pronounced in Scotland, Ireland, and parts of the north of England. Barnes consistently spells such words with wh- in his poems; but it is not clear whether the spelling is merely conventional, or whether it confirms the pronunciation with $/ \mathrm{hw} /$. Barnes does not comment on $w h$ - in the Diss., but in the 1886 Glossary, immediately after his list of words with aspirated initial $r$, he writes: "So Dorset has kept the hard breathed W, in some words from which it is often dropped, as hwey, whey. hwarf, wharf. hwing, wing" (p. 10, my italics). Two things are of note here: the phrase "in some words," which makes it clear that aspiration is not present in all words with wh-; and the inclusion of wing, always spelled with $w$ - in the poems (as in "The blackbird," “The sky a-clearèn," etc.), never with $h w$ - or $w h$-, which suggests that (as with initial $r$-) Barnes did not wish to show this aspiration in his poems. The only safe transcription appears to be $/(\mathrm{h}) \mathrm{w} /$, showing that aspiration is possible but not obligatory.

8.5.4 Who and whole are of course excluded from the preceding discussion, since their pronunciation in $\mathrm{StE}$ is with $/ \mathrm{h} /$ as opposed to $/ \mathrm{hw} /$ or $/ \mathrm{w} /$. I transcribe both words with $/ \mathrm{h} /$ as in $\mathrm{StE}$.

8.5.5 A well-known feature of west-country dialects to this day is the substitution of $/ \mathrm{j} /$ for $/ \mathrm{h} /$ in hear (and its derivatives) and here, (as well as the introduction of initial $/ \mathrm{j} /$ in ear), making these words homophones of year. But Barnes makes no mention of this feature in his grammars; his cs for Winterborne Came in EEP has /h/ in here (clause 1) as well as in hear and heard (clauses 4 and 13); and in his poems he normally spells these words with $b$-, and ear as in StE. I transcribe here, hear, and heard, accordingly, with $/ \mathrm{h} /$, and ear with no initial $/ \mathrm{j} /$ (except in instances where Barnes's spelling indicates clearly that $/ \mathrm{j} /$ is required, as in "yers" for "ears" in the 1844 version of "Uncle an' ānt").

\subsection{LM}

Barnes notes the intrusion of an epenthetic vowel (which I take to be schwa) into the consonant cluster - $I m$ (as in some pronunciations of film in current English): "The liquids $l m$ at the end of a word are sometimes parted by a vowel, as in elem, elm; auverwhelem, overwhelm; helem, helm" (Diss., \32; 
similarly in the 1863 Grammar, p. 18, and 1886 Glossary, p. 15). This observation is borne out in his poems by both scansion and spelling: elm on its own or in final position is always disyllabic / عləm/ (as in line 4 of "The Spring," the first poem in the first collection), and its normal spelling is elem. The one occurrence of the form elm that I am aware of in 1844, in the third stanza of "The d'rection post" ("The Leyton road ha lofty ranks / Ov elm trees upon his banks"), is evidently a printing error: elm must be disyllabic for the metre, and the spelling is elem both in the version in DCC and in later editions.

The first line of the second stanza of "Faïr Emily ov Yarrow Mill" ("But thy wold house an' elmy nook") shows the accuracy of Barnes's observation that it is only "at the end of a word" that a vowel intrudes: the octosyllabic metre requires that elmy be disyllabic, making elm itself in this instance monosyllabic / $/ \mathrm{lm} /$. Similarly, the spelling calm and the metrical need for a monosyllable at the beginning of the penultimate line of the first stanza of "Lindenore" ("Calm air do vind the rwose-bound door") confirm that it is only "sometimes" that the consonant cluster $l m$ in final position is "parted by a vowel".

\section{$8.7 N$}

8.7.1 After $v$. In the 1886 Glossary Barnes explains how, in the dialect he is describing, the sequence $/ \mathrm{v}(\boldsymbol{\partial}) \mathrm{n} /$ may develop into the consonant cluster $/ \mathrm{bm} /$ via the intermediate stage $/ \mathrm{v}(\partial) \mathrm{m} /$ : "When $\mathrm{V}$ and $\mathrm{N}$ (either in $e n$ as a wordending, or the pronoun en) come together, the $v$ often overwields the $n$ which in its new form overwields the $v$ that becomes $b$ " (p. 14). In modern terminology (more Latinate and perhaps also more opaque than Barnes's resolute Anglo-Saxon) (alveolar) $/ \mathrm{n} /$ becomes (bilabial) $/ \mathrm{m} /$ through the influence of an adjacent (labiodental) $/ \mathrm{v} /$, which in its turn is converted by (the bilabial) $/ \mathrm{m} /$ into (the bilabial) $/ \mathrm{b} /$. The examples Barnes gives to demonstrate this phenomenon are ebm (/ibəm/) from even via ev(e)m (/irvəm/), together with elebm, habm, heabm, obm, sebm (from, respectively, eleven, have-en 'have him', Heaven, oven, seven). Since, however, Barnes never uses the spellings $b m$ or bem for ven in his poems, it seems that this is one feature of the dialect that he chose not to portray. The halfway stage shown 
in 1844 in his spelling of evening, on the other hand (always evemen in 1844, replaced by evenèn in later editions) suggests that his preferred pronunciation of this word (in his poems, at least) is /i:vmən/.

8.7.2 After $b$ or $p$. In a similar way, and for similar reasons, Barnes explains that the object pronoun en becomes (bilabial) $/ \mathrm{m} /$ under the influence of a preceding (bilabial) /b/ or /p/; thus robm (/rbbəm/) is developed from rob en ('rob him'), and drubm, mobm, rubm, scrubm, dropm and stopm from drub en ('drub him'), etc. (1886 Glossary, p. 14). None of this, however, is shown in his poems.

8.7.3 As a final twist Barnes points out that (voiced) $/ \mathrm{m} /$ or $/ \mathrm{n} /$ can have the effect of converting a preceding (voiceless) $/ \mathrm{p} /$ into (voiced) $/ \mathrm{b} /$; thus open (o:pən) is likely to become /o:bən/ or /o:bəm/ (1886 Glossary, p. 14). This feature is shown frequently in Barnes's poems: in 1844 open is always spelled oben; in later editions it may be either oben or open. There are, however, no spellings suggesting the pronunciation with /əm/ for /on/. In accordance with Barnes's 1844 spelling I transcribe open always as /o:bən/.

\section{$8.8 R$}

8.8.1 Whereas RP is a non-rhotic accent (that is to say, the / $\mathrm{r} /$ sound originally heard in all words with $r$ in their spelling has now been lost when the $r$ appears at the end of a word or precedes a consonant), the SW is fully rhotic (i.e. $r$ is always sounded); indeed, as Wells says, "The preservation of historical $/ \mathrm{r} /$ in all environments is the best-known phonetic characteristic of the west of England" (4.3.5, p. 341). Thus the $r$ is audible (as it would be in GenAm) where it would be silent in RP in weather's, sparkle, toward, hear, and birds (to take some examples only from the first stanza of the first poem in Barnes's first dialect collection, "The Spring"); conversely, rhymes such as arm / calm and four / flaw, which have become normal in RP, are impossible for Barnes. Commentators have had a field day with the precise quality of this $/ \mathrm{r} /$ sound; for the purposes of this guide, however, I note merely that the $/ \mathrm{r}$ / in Barnes's dialect poems will always be distinctly heard. 
8.8.2 Full rhoticity has a tendency to spill over into hyper-rhoticity, i.e. the insertion of an $/ r$ / sound where there is no etymological justification for it. This is especially likely to happen in words ending in unstressed -ow (yellow, hollow, window, etc., which become yeller, holler, winder, etc.: see 7.14.8).

8.8.3 " $r$ in great, pretty, undergoes metathesis, making ghirt and pirty" (Diss., \$34; see 7.9.4). The spelling ghirt (for which see 8.4.1) is not used in Barnes's poems; but the metathesis of $r+$ vowel is consistently shown in the spellings girt or gert in almost all editions, as in the titles of two of his best-loved poems, "The girt woak tree that's in the dell" and "The settle an' the girt wood vire." (The misleading spelling gre't that is sometimes used in the third and fourth editions of the first collection is abandoned thereafter.) Pretty is always pirty in 1844, and thereafter either perty or pretty; I take it, however, that the pronunciation is always /pərti/, and that of great always /gərrt/.

8.8.4 "The liquids $r l$ of English words, such as purl, twirl, world, have frequently $d$ inserted between them, making purdle, twirdle, wordle ..." (Diss., \33). Barnes's spelling in 1844 accords with his comment in the Dissertation, curl, twirl, whirl and world all being spelled with -rdle (and pronounced, I take it, with -/ərrdəl/), and worlds ("wordles") rhyming with burdles in stanza 7 of “The Shepherd o' the farm”: “An' wi' my zong, an' wi' my fife, / An' wi' my hut o' turf an' hurdles, / I wou'den channge my shepherd's life / To be amiade a king o' wordles." But this stanza is omitted from later editions; world is respelled worold (thus keeping it disyllabic); and the other words are respelled as in StE (with compensatory adjustments to the wording where the loss of a syllable would disturb the rhythm) or with -rrel for -rdle (as in the maidens' "currels" in the second stanza of "Evenèn, an' maïdens out at door"). It seems clear, then, that Barnes decided not to portray the characteristic SW -/ardəl/ for -/arrl/ in later editions of his poems. We are left, then, with several possible pronunciations for words in this subset: -/arrdəl/ (as in 1844), -/arrl/ (as in StE), and -/ $\mathrm{ar}$ rəl/ or -/ərrəl/ (as implied by the spelling currel for curl). The first three of these are all offered as possible pronunciations for curl and purl in Barnes's contribution to EEP for Winterborne Came (cwl 805a-b). 
8.8.5 " $r$ before a hissing palate letter, $s, \mathrm{c}$, or $\mathrm{z}$, or $t$, as in burst, first, verse, force, furze, nurs'd, mirth, earth, birth, worth, is thrown out, making bust, vust, vess, fuoss, vur\%, nuss'd, meth, eth, beth, woth" (Diss., \$35). This observation is consistently borne out by Barnes's spelling: see 7.8.4, 7.22.4, and 7.9.5.

8.8.6 For possible aspiration of initial $r$-, resulting in the pronunciation $/ \mathrm{hr} /$, see 8.5.2.

\{8.8.7 Loss of / $\mathrm{r} /$ before final / $\mathrm{d} /$ in an unstressed syllable is shown in the spellings archet and orcha'd for orchard and Richat for Richard (this latter in "Eclogue: Emigration"); conversely the forms shepherd and Roberd (the usual 1844 spelling of Robert) show its retention in some words.\}

$8.9 \mathrm{~S}$

8.9.1 " $S$ before a vowel often but not universally becomes in Dorset its smooth kinsletter ₹, making sand, zand; sap, zeap; send, zend; set, zet; sick, zick; some, zome; sop, zop; and sun, zun" (Diss., \$36; see \$17 for Barnes's explanation of the terms rough and smooth). To this may be added $s$ before $w$ (since there are many occurrences of zw- spellings-zwath, aweat, zwell, zwing, etc.), together with the plurals of face and place (-ren as opposed to -ces). Since, however, there is no certain way of predicting when the $s$ - will be voiced and when not, Barnes's "often but not universally" seems as precise a formulation as one could hope for, and his decision to retain the z-spellings of affected words in later editions is much to be welcomed. \{Nevertheless line 9 of 'Early plaÿmeäte' ('There wer zome things a-seemèn the seäme') shows that the spelling is not always to be trusted, since the triple alliteration in the penultimate line of each stanza in this poem demands $/ \mathrm{s} /$ here rather than $/ \mathrm{z} /$ for some.\}

8.9.2 "In many English words ending with $s$ and a mute consonant, those letters have undergone metathesis, since in Anglo-Saxon the $s$ followed the consonant, as it does in the Dorset dialect; in which clasp is claps; crisp, crips; hasp, haps; wasp, waps; and to ask, to aks (ax), the Anglo-Saxon axian" (Diss., \$37). To the best of my knowledge the only word in this list that occurs in Barnes's poems is ask: in accordance with his comment here it is always spelled ax (/akks/).There is also the word clips, which occurs, always 
in the infinitive, in five of Barnes's poems ("The sky a-clearèn," "The wold vo'k dead," "Brookwell," "Shop o' meat-weäre, and "The little hwomestead"), and which is defined and exemplified in the 1844 Glossary (with a cross reference to $\$ 37$ of the Diss.) as "To clasp between the thumb and fingers, or between the two arms. I can clips thik tree."

\subsection{3}

The voiced $s(/ \mathrm{z} /)$ in isn't and 'tisn't is replaced by /d/, as shown by Barnes's consistent spellings idden and tidden in both early and late collections.

\subsection{SH and $S$ representing $/ \mathrm{S} /$}

Voicing of initial $/ \mathrm{S} /$ to $/ 3 /$ is a characteristic of SW dialects generally considered to be as firmly established as voicing of initial /s/ to /z/ (Wells, 4.3.6, p. 343; Wakelin, I.4.2, p. 29), but it is a feature not normally shown by Barnes. There is one isolated example of zure for sure in John's final speech in the 1844 version of "The common a-took in" amongst many examples of sure elsewhere in the collection; in later editions, however, it has been altered to sure. I transcribe sure, accordingly, always with initial $/ \mathrm{S} /$.

\subsection{SHR}

The spelling of 1844 indicates simplification of the consonant cluster $/ \mathrm{Sr} /$ to $/ \mathrm{S} /$ by loss of $/ \mathrm{r} /$, as in Shodon and sh'oud for Shroton and shroud. The $-r$ - is often (but not always) restored in later editions, suggesting that pronunciations with $/ \mathrm{gr} /$ and $/ \mathrm{S} /$ were both acceptable. Shrill is perhaps a special case: Barnes's preferred spelling in 1844 is shill (three occurrences, in "The woodlands," "The blackbird," and "The music o' the dead," as against one occurrence of shrill, in "The woody holler"). The spelling shill (as against sh'ill, which does not occur in 1844) may suggest that the word in question is not in fact shrill with loss of $-r$ - but the more or less synonymous shill (from OE scill 'sonorous, sounding'; EDD, shill, adj. ${ }^{1}$ ). But this is not certain: the form shill is abandoned in later editions; its three occurrences in the First Collection are all replaced by shrill, and elsewhere the spellings sh'ill and shrill are both frequently used. 


\section{$8.12 T$}

8.12.1 Intervocalic / $t$ / is generally said to be voiced throughout the SW (as in GenAm): " $L A E$ shows butter with [d] everywhere south-west of a line from Weston-super-mare to Portsmouth" (Wells, 4.3.6, p. 344). But the situation is not quite so clear-cut. Barnes seems always to have $/ \mathrm{t} /$ : he gives no indication of $/ \mathrm{d} /$ either in his grammars or in the spelling of his poems \{except very rarely, as in nodice for notice in the 1844 and 1847 versions of “Eclogue:-A bit o' sly coortèn" \}, and his contribution to EEP has $/ \mathrm{t} /$ in little and kettle (cs, clauses 10 and 12), the only eligible words for which his responses are recorded.

8.12.2 "An open palate letter is sometimes substituted for a close one" (cf. 8.2.1 above), in this instance " $k$ for $t$; as ... pank, to pant" (Diss., \$39). To the best of my knowledge pant is the only word in which $/ \mathrm{k} /$ replaces $/ \mathrm{t} /$ in this way; it is always shown by Barnes's rhyme and spelling, in both early and late editions, as in the rhyming of pank with bank ("Dock leaves", "John Bloom in Lon'on") and spank ("John Bloom in Lon'on").

\subsection{TH (excluding THR)}

8.13.1 "Where the English rough articulation th, as in thin, the Anglo-Saxon $\mathrm{p}$, becomes in Dorsetshire its soft kinsletter th as in thee, the Anglo-Saxon $\partial$, as it does very frequently, the author has printed it in Italics th, as think" (Diss., (38). That is to say, when voiceless th is voiced (as it frequently is in Dorset) Barnes prints the th in italics in 1844 (replaced by $\partial$ in 1847); if the th is voiceless in RP and is not printed in italics in 1844, we may assume that it remains voiceless in Barnes's dialect. This statement does not propose any rule by which we can predict when th will be voiced and when not: as with voiced and voiceless $s$, we are in the territory of "often but not universally" (see 8.9.1 above). This would be of little concern to readers if Barnes had stuck to his policy of indicating typographically when voiceless th becomes voiced; the problem is that he abandoned this policy in later editions, in which he gives no indication as to when a th that is voiceless in StE is to be voiced. It may therefore be helpful to list here all words in which voiceless th in RP is shown to be voiced in the poems and/or glossaries of 1844 and 
1847, the 1879 Glossary, and the 1886 Glossary (p. 9): athirt and thirtawver, both and loth, thatch, thaw, thief, thiller and thillharness, thik, thimble, thin (adj.), thin (v.), thing, think and thought (v.), thistle, thorn, thumb. (Words with voiced th in RP in which the th is superfluously italicized in 1844 are omitted from this list.) The only words in which initial th is not shown to be voiced in 1844 are thick, thigh, thought (noun, and in the compounds thoughtful and thoughtless), thousand, thump, and thunder. \{It is not clear whether the single instance of italicized th- in thought, noun, in 1844 (in "The happy daes when I wer young") is an oversight, or whether it shows that both voiced and voiceless pronunciations were acceptable. $\}$ In the transcription of his poems I have relied on Barnes's typographical conventions in 1844 and 1847 and on his lists of the words in which th is voiced.

8.13.2 In a sentence added to $\$ 38$ in the expanded Dissertation of 1847 Barnes notes the loss of medial or final th in some words: "th go out in wi', for with; gramfa'r, grandfather; grammo'r, grandmother; le's, let's." (The placement of let's in this list of words with omitted th is evidently a slip.) In the poems (both early and late editions) grandfather and grandmother are always spelled gramfer and grammer, evidently with $/ \mathrm{m} /$ for $/ \mathrm{nd} /$ and a final syllable reduced to /or/. With is occasionally spelled out in full, but usually it is $w i$, "pronounced wee" according to the 1844 Glossary. This implies lengthening as well as raising of the vowel (cf. gi'e for give, 8.15.1); since, however, wi' is rarely stressed, the likelihood must be that the sound is usually that of the "the happY vowel" (see 7.1.2), namely /i/ rather than /i:/.

8.13.3 Though not included in Barnes's list in the preceding paragraph, clothes is evidently another word in which medial /ð/ is lost, as shown both by the spellings cloas or cloaz in 1844 and by rhymes on the sound /o:z/ (e.g. a-vroze "The vrost", shows "Martin's tide"). That these rhymes are retained in later editions even when clothes has its StE spelling suggests that the pronunciation for Barnes is always /klo:z/, irrespective of the spelling.

\subsection{THR}

" $d$ is substituted for initial th; as drow for throw; droo, through; drash, thrash; drong, throng; droat, throat; drashel, threshold" (Diss., 『29). In the 1863 Grammar Barnes points out that this substitution takes place "mostly before 
$r$ " (p. 16); his examples suggest that it happens only before $r$. In phonemic terms initial $/ \theta \mathrm{r} /$ becomes $/ \mathrm{dr} /$, a feature widely noted by commentators on SW dialects. (Except in a few stray instances the $d r$-spellings are reinstated in Barnes's 1879 edition, though some had been abandoned in intermediate editions after 1844.) The sole exceptions to the substitution of $/ \mathrm{dr} /$ for $/ \theta \mathrm{r} /$ in Barnes's poems are thrive and thrill; it may be that $/ \theta \mathrm{r} /$ is retained in thrill to prevent confusion with drill, but possible confusion between thrive and drive can hardly be urged as a cause for its retention in thrive, since drive has a different vowel in Barnes's dialect (see 7.10.6).

\section{$8.15 \mathrm{~V}$}

8.15.1 " $v$ is sometimes omitted, as gi'e, give; ha', have; sar, serve" (Diss., \40). Barnes's spelling in his poems suggests that in have the /v/ may be included or omitted indifferently; in serve it is usually omitted, but may be retained in rhyme where needed (as in sarve ye/starve ye, "Eclogue: The times"); in give it is normally omitted, but sometimes retained in derived forms such as givèn. Rhymes show that when $/ \mathrm{v} /$ is omitted from give, the vowel is raised and lengthened, producing the form /gi:/ (as in gi'e/be, "Eclogue: Father come huome").

8.15.2 For the sequence $/ \mathrm{v}(\boldsymbol{\partial}) \mathrm{n} /$ see 8.7.1.

\section{$8.16 W$}

8.16.1 Loss of initial /w/ is a common feature in SW dialects, but since it is a feature on which Barnes makes no comment, the only safe policy is to be guided by the spelling of 1844: his usual spelling of within and without is with no initial $w$, but there are occasional occurrences of without spelled as in StE, suggesting that forms with and without initial /w/ are both acceptable; will is usually wull but occasionally will, 'ool, or 'ul(l), so that /wol/, /wil/, and / $\mathrm{ul} /$ are all possible; would is variously would, woud, wou'd, wood, woo'd, 'ood, or 'od, so that /wud/ and /ud/ are evidently both possible, even though the spellings without initial $w$-are abandoned in later editions. Where, on the other hand, Barnes never uses spellings without $w$ - in his poems (as with woman, women, 
wood, and wool), I assume that he wished initial /w/ to be retained. For one and once, both of which have initial /w/ in RP, see 7.5.7.

8.16.2 Loss of medial /w/ in words such as upward is common in regional dialects throughout England and sometimes reflected in Barnes's spelling. Athwart is always athirt (the italicized th in the spelling of 1844, "athirt," showing that loss of $/ \mathrm{w} /$ is accompanied by voicing of the preceding $/ \theta /$ to /ð/, hence /əðərrt/, see 8.13.1); somewhat is variously zome'bat, zome'at, or zummat, all of which I take to be /zımət/.

8.16.3 As Wakelin points out, in SW dialects / w/ may be added initially or after a preceding consonant before long back vowels, "but its interpretation is open to question" (I.4.4, p. 33). In Barnes's case insertion of /w/ before /a:i/ appears to be normal in boil, spoil, point, poison, toil, and boy (see 7.17.1 and 7.17.4). On the interpretation of the $w$-glide before the sound traditionally called "long 0 " see 7.14.1-4.

\section{$8.17 \mathrm{WH}$}

8.17.1 On the question of aspiration in words containing $w h$ - see 8.5.3.

8.17.2 Loss of medial $w h$ is shown in spellings such as zummat for somewhat (see 8.16.2).

\section{$8.18 Y$}

When ye is grammatically dependent on the preceding word, its initial $/ \mathbf{j} /$ is frequently lost and the /i:/ assimilated to the preceding word. Thus can ye sounds like canny and rhymes with Fanny ("Eclogue:-A bit o' sly coortèn"); tellye sounds like telly and rhymes with belly ("Eclogue:-The times"), and so on. 


\section{By the same author}

The Complete Poems of William Barnes. (Ed. with K. K. Ruthven.) 3 vols. Oxford: Oxford UP. 2013-.

Six Eclogues from William Barnes's Poems of Rural Life in the Dorset Dialect (First collection, 1844) with phonemic transcripts and an audio recording from the 2010 Adelaide Fringe. Adelaide: Barr Smith Press, 2011.

William Barnes's Dialect Poems: A Pronunciation Guide. Adelaide \& Provo: Chaucer Studio Press. 2010.

The Vaices That Be Gone: Selected Poems from William Barnes's Poems of Rural Life in the Dorset Dialect (First collection, 1844) with phonemic transcripts and an audio recording from the 2009 Adelaide Fringe. Adelaide \& Provo: Chaucer Studio Press, 2009.

Long Words Bother Me, with illustrations by Michael Atchison. Stroud, Glos: Sutton, 2004. (A revised and expanded reprint of Words, Words, Words and Words in Your Ear.)

Sidrak and Bokekus: A Parallel-Text Edition from Bodleian Library, MS Laud Misc. 559 and British Library, MS Lansdowme 793. 2 wols. Earby English Text Society, 311 and 312. Oxford: Oxford UP, 1998-99.

Words in Your Ear, with illustrations by Michael Atchison. Adelaide: Wakefield Press, 1998.

Words, Words, Words, with illustrations by Michael Atchison. Adelaide: University Radio 5UV, 1995. 


\title{
Electronic Index
}

\author{
This book is available as a free fully-searchable \\ ebook from
}

www.adelaide.edu.au/press

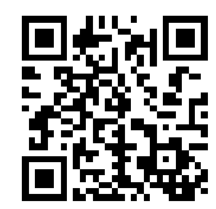

